THE DUTCH EAST INDIA COMPANY AND MYSORE 
Jan van Lohuizen - 978-90-04-28655-9 Downloaded from Brill.come4/26/2023 09:57:33AM via free access 


\title{
VERHANDELINGEI
}

VAN HET KONINKLIJK INSTITUUT VOOR TAAL-, LAND- EN VOLKENKUNDE

\author{
DEEL XXXI
}

\section{THE DUTCH EAST INDIA COMPANY AND MYSORE}

1762 - 1790

BY

JaN VAN LOHUIZEN, Ph. D.

'S.GRAVENHAGE - MARTINUS NUHOFF - 1961 
Jan van Lohuizen - 978-90-04-28655-9 Downloaded from Brill.come4/26/2023 09:57:33AM via free access 


\section{CONTENTS}

Page

NOTE ON ABBREVIATIONS, CURRENCY AND WEIGHTS . . . . . . . VI

PREFACE . . . . . . . . . . . . . . . . . . . . VII

INTRODUCTION . . . . . . . . . . . . . . 1

I THE DUTCH AND HAIDAR ALI, 1762-1766 . . . . . . . . 22

II FROM ONE EMBASSY TO ANOTHER, 1766-1775 . . . . . . 52

III YEARS OF GROWING ESTRANGEMENT AND HOSTILITIES, 1775-1781 88

IV WAR WITH THE BRITISH, 1781-1783 . . . . . . . . . 115

v THE DUTCH AND TIPU SULTAN, 1784-1790 . . . . . . . . . 135

CONCLUSION . . . . . . . . . . . . . . . 164

APPENDIX I：THE ORIGIN OF THE NAIR REBELLION OF 1766 . . . 171

APPENDIX II : THE CONQUEST OF COORG AND CALICUT IN 1773-1774 177

APPENDIX III : THE MXSOREAN-DUTCH AGREEMENT OF 1781 . . . 180

BIBLIOGRAPHY . . . . . . . . . . . . . . . . . . 183

INDEX . . . . . . . . . . . . . . . . . . 202

MAPS 


\title{
NOTE ON ABBREVIATIONS, CURRENCY AND WEIGHTS
}

\author{
L.f.B. Letters from Batavia \\ (Overgekomen brieven van Batavia) \\ L.f.C. Letters from Ceylon \\ (Overgekomen brieven van Ceylon) \\ L.f.Cor. Letters from Coromandel \\ (Overgekomen brieven van Coromandel) \\ L.f.M. Letters from Malabar \\ (Overgekomen brieven van Malabar)
}

Sel. Dutch Records Madras Selections from the Records of the Madras Government, Dutch Records

s.1. secret letter

Although rupees and pagodas of different values were in use it will be sufficient for the purpose of this study to reckon as follows :

1 pagoda is approximately equivalent to 4 rupees or 8 shillings or 5 guilders.

1 lakh is 100,000 .

1 candy is $500 \mathrm{lbs}$ Dutch or $550 \mathrm{lbs}$ avoirdupois approximately. 


\section{PREFACE}

Only very few Dutch historians have been working in the field of the activities of the Dutch East India Company in India, and their main interest was often directed to the period in the 17th century during which Dutch settlements were founded in different parts of the subcontinent. Detailed studies by Dutch authors on the development of these settlements during the 18th century are lacking almost completely.

As far as Malabar is concerned, the works of the English authors Day and Logan, published during the second half of the last century, have contributed to a wider knowledge of the Dutch in the later period. In more recent years Indian scholars have consulted Dutch documents either for the study of Dutch activities in Malabar (e.g. Panikkar and Alexander), or within the context of Indian history in the 18th century (Hayavadana Rao, Sinha and Khan). But the work of none of these writers seems to me entirely satisfactory, either because unfamiliarity with the Dutch language has resulted in errors, or, and more important, because these authors have consulted only a fraction of the Dutch sources available. They have restricted themselves to comparatively few letters or some of the volumes of Dutch records published at Madras in the beginning of this century. The greater part of these published records are Memoirs written by the heads of the administration at the time of their departure in order to give their successors some idea of their duties. They are of value, and sometimes even indispensable, but their importance should not be overestimated in view of the abundant mass of other contemporary material.

Another point in connection with the available sources is that although Malabar ranks as the most important area of contact between the Dutch and Mysore, there were others as well, Coromandel and, indirectly, Ceylon and Batavia, which should not be neglected. Several episodes could not have been dealt with in this study if I had depended only on the sources which are concerned with Malabar.

The chief material which I have used consists of the manuscript records kept in the General State Archives at the Hague. These contain letters, proceedings, resolutions and other papers, which were regularly sent from the different settlements to Batavia, to Holland, and to one 
another. Most of these may be found in the hundreds of volumes of the "Overgekomen brieven", i.e. Letters sent from Batavia, Malabar, Ceylon, and so on. In addition, use has been made of some unpublished English records kept in the Commonwealth Relations Office and the Bodleian Library.

I cannot claim to have stringently followed the Hunterian system in the spelling of geographical and personal names. In some cases I have preferred a spelling which, while being familiar to English eyes, stands nearer to the Dutch spelling of the name (e.g. Cranganore instead of Kranganur or Kodungalur), in a few others I have even kept to the Dutch spelling because the English equivalent, as far as I know, does not exist (e.g. the name of Cochin's chief minister). On the whole, however, the spelling of names is in accordance with Hunter's system, and I do not anticipate that the exceptions will lead to misunderstandings.

I should like to express a word of thanks to Dr. T. G. P. Spear, Fellow of Selwyn College, Cambridge, who acted as supervisor during my period of research for the Ph. D.-degree at Cambridge University. Although I am afraid that the subject of my thesis lay somewhat outside the field of his main interest in Indian history, his guidance and kindness have meant a great deal to me.

I am also grateful to the staffs of the General State Archives at the Hague, the University Libraries at Cambridge and Leyden, the Bodleian Library, and to Mr. Stanley C. Sutton, Librarian of the India Office Library and his staff. The atmosphere of extreme friendliness and helpfulness in this treasure-house of orientalism is most stimulating to research.

I further wish to thank Mrs. Th. H. J.de Josselin de Jong at Leyden who was so kind as to look through the manuscript at an earlier stage and to suggest valuable corrections in the English. In this respect I also owe words of thanks to my wife who, besides, has always been a source of encouragement during the period in which this study was prepared. The mistakes which critical eyes are bound to find in the English are mine, but I take comfort in the hope that these errors will not prevent the reader from grasping what is really meant.

Finally, my respectful thanks are due to the Board of the Koninklijk Instituut voor Taal-, Land- en Volkenkunde for its decision to publish this work in its series of Monographs. 


\section{INTRODUCTION}

In the early sixties of the 18th century the political scene in India was thoroughly unsettled. Dissolving forces in the Mogul empire had finally created a void in Delhi and while the emperor had taken refuge in the east, Afghans and Marathas struggled for the heritage of imperial power. The first repelled the latter at Panipat in 1761 but they lacked the strength to reap the fruits of their victory and withdrew westwards. At the same time the emperor's attempt to regain his power in the east was checked by a British force. Shortly afterwards he became an English stipendiary in return for his confirmation of the new Nawab of Bengal who like his deposed predecessor owed his status to the Council at Calcutta. ${ }^{1}$ Although there was an undeniable growth in English influence in the north, the ultimate outcome of the various opposite trends must have been anybody's guess at the time.

In the south the situation was not essentially different. Here too, the British had been gaining prestige as a result of the Seven Years' War which ended dreams of a French India. There still were, however, several uncertain factors. Would the British be able to follow up their military victory by extending their political control, or would they be content with concentrating on their trading activities? What would be the reaction of the Marathas to their defeat in the north? Intensification of their interference in South India? And how would the new rulers of Hyderabad and Mysore, the usurpers Nizam Ali and Haidar Ali, fit into the general picture? These were among the many questions to which nobody could give a well founded reply at the beginning of 1762 . One thing, however, stood out clearly. Among the Europeans in India the English had reached the stage of pre-eminence. More than a century earlier the Portuguese had been surpassed by the Dutch and English, and in the early 18th century the Dutch had started falling behind the English and French.

There was no indication that the political situation in Europe would halt or even reverse the process of development in India in the near

1 See K. A. Nilakanta Sastri, History of India, III (Madras, 1952), pp. 72 and 91.

V.K.I. 31 
future. The Dutch Republic had long ceased to be one of the great powers. Its military strength had declined to such an extent that at the outbreak of the Seven Years' War neutrality was the only possible policy. This meant renunciation of the old alliance with England. By the end of the war England stood practically isolated among the European powers but this seemed irrelevant to the Indian situation as long as she remained the chief naval power. In 1762 her command of the seas was underlined by successes against the Spanish colonies in the West Indies and the Philippines. Moreover, the isolation in Europe might be called an advantage in that it fortified a tendency to concentrate on affairs in the overseas territories. France, on the other hand, might well be longing to build up strength in order to reverse the disgraceful outcome of the war, but she would always be handicapped by the fact that because of her position on the Continent she could never focus her policy on overseas affairs to the same extent as England.

After this outline of the general situation we should now retrace the main events leading to the positions occupied by the Indian powers and the Europeans in South India at the beginning of the period covered in this study.

One of the early discoveries the Dutch and English made when about 1600 they entered the Malay Archipelago in search of pepper and other spices, was the important part played by cotton goods from India in the process of obtaining those valuable commodities for the European markets. Indian textiles proved to be the answer to the difficult problem what to offer in exchange for spices. European wares were not of much use in this respect, and taking out silver as the Portuguese had done met with objections, not only at home - especially in England - where influential circles resisted such a drain on the country, but also in the production centres in Java and the Spice Islands where money-economy was still in its infancy. Moreover, shipment of bullion over long distances was, certainly in those days, rather a risky undertaking. These considerations required a solution of the problem by which as few precious metals as possible were sent from Europe while at the same time this amount should be used primarily elsewhere so as to develop commercial relations in support of the main object, the spice trade. At the very beginning the easiest solution seemed to be buying the Indian cotton goods from middlemen at Achin or Bantam, but for obvious reasons it was soon found more attractive to become independent of these middlemen by trying to establish direct trade relations with the centres of production in India. And so, during 
the first decades of the 17th century the English and the Dutch appeared at Masulipatam and Pulicat on the Coromandel coast and in Surat, the emporium of the Mogul empire on the west coast. ${ }^{2}$ Here money-economy had existed for centuries and the Europeans very soon noticed that whatever foreign commodities they might have to offer precious metals would always have to be the mainstay of their supply. Apart from carrying out bullion there were two other expedients for obtaining cash, namely borrowing in the Indian market and exploiting those commercial possibilities in Asia which would render silver and gold. For this reason the Red Sea trade with its payment in cash became attractive, but even more important were China and Japan. Here the ways of the English and Dutch Companies parted, for setbacks in Japan and the Spice Islands, where the Dutch laid the foundation of what was to become their spice-monopoly, forced the English to restrict their activities to more western areas. ${ }^{3}$

During the first half of the 17 th century the Dutch succeeded in gradually developing a commercial system which brought them the silver of Japan in exchange for Chinese silk, obtained in Indo-China for Indian cotton goods, and hides and skins, obtained in Siam for Indian textiles. Moreover, merchants from China and Indo-China paid in gold for pepper, sandalwood and other commodities which were practically all bought with Indian cotton goods. About 1650 a large proportion of the requirements of the Dutch in India was supplied by direct shipments from Formosa (in Dutch hands from 1642 to 1662), gold to Coromandel and silver to Gujarat and Bengal.4

The development of these activities in Asiatic trade was reflected in the expansion of Dutch settlements in the East. Almost immediately on their arrival there the merchants of the Companies felt the necessity of establishing permanent footings, factories, where their servants could continue business during the periods that their ships had left. The expenses of these of ten simple settlements - a residence for a few Company servants and a storehouse for the commodities either rented or bought were the essential elements - were usually outweighed by the savings on transactions no longer restricted to the short stay of the ships from Europe.

2 Comp. G. N. Clark in Part II of The colonial conferences between England and the Netherlands in 1613 and 1615 (Leiden, 1951), pp. 23-4.

3 Comp. W. H. Moreland, From Akbar to Aurangzeb (London, 1923), pp. $59-64$.

Ibid, pp. 65-6. 
Generally it was not so difficult to get permission to start a factory, for the local authorities who were approached with such requests were not slow in recognizing the advantages of expanding commercial relations which often implied admitting new competitors of traders who had settled previously. As a rule the main issue in drawing up the terms of trade was fixing the duties levied upon imports and exports. ${ }^{5}$ Whereas the start was usually comparatively easy, difficulties developed rather often in a second stage soon afterwards. They resulted from a different outlook upon the agreements reached in the beginning. To the Dutch these agreements were stable and impersonal contracts, but on the other side they were regarded as binding at best the person who had concluded them. His successor might continue them if he felt like it but in most cases he would then expect something in return for what he considered a favour. ${ }^{6}$ Moreover, subordinate officials would often assume a similar attitude and manifold changes in local governments - the Dutch found that the governor of Masulipatam rented the administration of this town from the king of Golconda for a large sum and might be superseded annually 7 - were responsible for many an entry "presents" in the Dutch accounts.

Sometimes a weak local government was unable to provide sufficient protection to a factory and it happened that the merchants were allowed to fortify their factory and arrange for their own defence. An early example in Coromandel is the Dutch fort Geldria at Pulicat, built after the destruction of their factory by the Portuguese of St. Thomé in 1612.8 Of course, the possession of a fort helped considerably in con. solidating the position of the traders, but it also entailed greater expense. Under a strong government as the Mogul empire provided at Surat, or Golconda at Masulipatam, there was no question of erecting forts and the foreign merchants had to be satisfied with factories. But whereas the Moguls gave North India growing stability and unity, the political situation in South India showed increasing disruption.

Early in the 14th century the Hindu kingdoms in southern India

5 The first example of such a Dutch factory in Java was that at Bantam opened in 1603.

- Comp. W. H. Moreland and A. C. Chatterjee, A Short History of India (2nd ed., London, 1945), p. 237.

$7 \mathrm{H}$. Terpstra, De vestiging van de Nederlanders aan de kust van Koromandel (Groningen, 1911), p. 46.

8 See H. Terpstra, „De Nederlanders in Voor-Indië bij de stichting van het fort Geldria te Paliacatta", De Indische Gids, 37 (Amserdam, 1915), pp. $331-60$. 
had for the first time experienced the penetration of the Muslims from the north. Even a town situated as far south as Madura had been occupied. At first it had been administered for the sultanate of Delhi by a governor, but subsequently his descendants established themselves as independent rulers for several decades. A second independent Muslim kingdom was formed towards the middle of the century in the Deccan, the Bahmani sultanate. At about the same time a new dynasty established itself south of the river Kistna and founded the strong Hindu kingdom of Vijayanagar. With the destruction of the Madura sultanate by Vijayanagar in 1378 Muslim influence was driven back north of the Kistna. ${ }^{9}$ The 15 th century saw a continuation of the struggle between the Bahmani and Vijayanagar kingdoms. Towards the end of the century the first broke up into five separate sultanates - Bidar, Ahmadnagar, Berar, Bijapur and Golconda. Disintegrating forces, however, were not lacking in Vijayanagar either and frequently provincial governors paid more attention to their own interests than to those of the state. The result was that in 1565 the combined forces of the Muslim sultanates succeeded in destroying Vijayanagar. ${ }^{10}$ The dynasty withdrew to the south-east where the Dutch were to meet its descendants at Vellore as "kings of the Carnatic" in the beginning of the 17th century. From north to south we find at this stage along the eastern coast of India the Mogul empire, which had supplanted the sultanate of Delhi in the 16th century, the sultanate of Golconda and the "kingdom of the Carnatic", which had among others the chiefs of Gingi, Mysore, Tanjore and Madura as tributaries. Still further south there were several petty rulers. Finally, the Portuguese had key-points in Coromandel at Negapatam and St. Thomé.

The first Dutch factory was opened in 1605 at Masulipatam, the principal seaport of Golconda.11 The special qualities of a red dye used at Nizampatam, also in Golconda, were a reason for establishing a second factory at this place in the next year.12 These first years were very trying indeed for the Company's 13 servants on account of differences about customs and extortion by local officials. In order to become less dependent on the dignitaries in Golconda attempts were made to

${ }^{9}$ Moreland and Chatterjee, op. cit., pp. 173-4.

10 Ibid., pp. 182-3.

11 Terpstra, De vestiging ..........., pp. 34-5.

12 Terpstra, Ibid., pp. 38-9.

13 Where "the Company" is referred to in this study the Dutch East India Company is meant. 
settle also somewhere else on the Coromandel coast. A first result was an agreement in 1608 with the chief of Gingi who promised the Dutch protection at Tegnapatam. ${ }^{14}$ In 1610 the same chief threw open Porto Novo to the Dutch, but they did not avail themselves at once of this opportunity.15 Far more important became the factory founded in the same year in the Carnatic kingdom at Pulicat, where the artisans had specialized to some degree in the types of clothes worn in the Spice Islands. ${ }^{16}$

By now the need was recognized of a central management of the Company's affairs in Coromandel as well as of those in the East as a whole. In 1609 the first Governor-General of the Company was appointed, a year later the first Director of the Coromandel factories was nominated with Pulicat as his station. 17 Otherwise the next period showed a conduct of affairs totally different in the Malay Archipelago from that in India. Whereas an offensive policy in the east resulted in the ousting of the Portuguese 18 and Spaniards and the keeping in check of the English competitors and the inhabitants of the Spice Islands and other territories, the penetration into India went along purely commercial lines and the policy was generally defensive rather than offensive in character. While great events were taking place in the east, the servants of the factories in Coromandel, and soon afterwards also those in Surat and elsewhere in the Mogul empire, had to use all their skill, patience and perseverance to keep a profitable trade going and to preserve the friendship of the officials whom they had to deal with. Experience and a fair knowledge of commodities were required to make the purchase of the main object, cotton goods, a success. Ox-drivers carrying salt from the coastal regions brought back as return cargo cotton grown in the interior. Indian merchants then gave it to spinners and weavers who produced the differcnt types of cloth. 19 There were many local specializations but the main distinction to be made was between plain and patterned goods. The first could be subdivided into muslin, a thin cloth, and calico, a stouter cloth, both of which were produced in various qualities. Coloured patterns applied

\footnotetext{
14 Terpstra, De vestiging

15 Ibid., pp. 117-8.

16 Ibid., pp. 121-5.

17 Ibid., pp. 154-8.

18 From 1580 to 1640 the Portuguese as subjects of the Spanish Crown were involved in the Dutch war of independence against Spain.

19 Pieter van Dam, Beschryvinge van de Oostindische Compagnie, Tweede boek, deel II, ed. F. W. Stapel ('s-Gravenhage, 1932), p. 148.
} 
to muslin or calico produced the second type of goods, the prints. 20 In the initial stage the Company's servants depended for their purchases on Indian merchants who brought the finished product from the weaving villages up country to the factories on the coast. In the immediate neighbourhood of the factories, however, the servants started to deal directly with the producers by ordering certain amounts of a sample given to the weavers. This procedure implied following the existing practice of giving advances to the producers so as to urge them to finish the orders in time, i.e. before the ships were due, and also to prevent them from accepting orders from others at the same time. Later on the Company engaged its own Indian brokers and merchants and made successful efforts to establish an even stronger hold on the producers by renting whole villages where weavers, washers, bleachers and dyers were living. Perhaps an even better guarantee of an uninterrupted and satisfactory production was obtained when it was possible to employ the artisans in the factory itself. The Dutch merchants had to supervise the activities of the producers, not only in or near the factories but often further away as well, so that their rounds of inspection along villages where artisans worked for the Company might take them several days. They had to develop a keen eye for imperfections in the workmanship and the use of inferior raw materials. In order to prevent the dyers from using the cheap but inferior quality of indigo common in southern Coromandel the Dutch sometimes provided them with the more expensive quality of the northern region. Other products bought by the Dutch were iron and steel manufactured at some distance inland and exported via Masulipatam, diamonds from the mines around Kollur, indigo and saltpetre, although these last two commodities were mainly obtained in the Mogul empire.21 Among the imports were gold and silver - the real-of-eight worth somewhat less than the pagoda - sandalwood from Timor and Solor, spices, Chinese silks, porcelain, lacquer, camphor, and metals other than iron. ${ }^{22}$ In Golconda the Company extended its trading activities to the capital where, partly in view of contact with the court, a factory was eventually opened. Here the imports were sold to Indian merchants who regularly bought a comparatively small stock for which they paid when applying

$20 \mathrm{~W}$. H. Moreland, Relations of Golconda in the carly seventeenth century (London, 1931), p. XVIII.

21 H. Terpstra, De Nederlanders in Voor-Indië (Amsterdam, 1947), pp. 62-8.

22 Terpstra, De vestiging pp. $176-80$. 
for the next supply.23 This inland factory, however, remained an exception in this part of India, for farther south sufficient stability guaranteeing a profitable trade in the interior was lacking.

To a certain extent Dutch activities in southern Coromandel were of course also checked by the Portuguese key-points at St. Thomé and Negapatam. Yet, these certainly did not belong to the most important centres of Portuguese power in the East and their commercial significance had declined as a result of the competition from other Europeans amongst whom the Dutch stood foremost. Portuguese power was stronger at Malacca, in Ceylon, on the Malabar coast and at Goa, the capital of the Portuguese possessions in the East. From 1637 onwards blockade-fleets were regularly sent by the Dutch to Goa. This made it difficult for the Portuguese to reinforce their possessions at Malacca and in Ceylon where they commanded not only the ports but had also penetrated into the interior. The Dutch, at this time allied with the king of Kandy, succeeded in taking several of these ports. Malacca, which the Company had in vain attempted to capture earlier in the century, fell in the beginning of 1641.24 In the same year the Dutch Republic and Portugal concluded an armistice for ten years.

The conquest of Malacca not only consolidated the trade position of Batavia, since 1619 the capital of the Dutch possessions in the East, but it also improved the Company's political prospects in Java, as from then onwards the rulers of Bantam and Mataram could no longer count on the Portuguese enmity with the Dutch.25

The resumption of hostilities with the Portuguese in 1652 took rather an uneventful course during the first few years when the AngloDutch Naval War in Europe and risings in the Moluccas prevented the sending of sufficient reinforcements to Indian waters. Later on, however, action on a larger scale resulted in the conquest of Colombo in 1656. The area of cinnamon production along the southern and western coasts, the principal reason for European interest in the island, was now in Dutch hands, but it obviously would remain a precarious possession as long as the Portuguese kept a footing in the north of Ceylon. Consequently, the Company pushed on the offensive, Goa was kept blockaded and in 1658 Tuticorin, Manar, Jaffna and Negapatam

23 Pieter van Dam, op. cit., pp. 163-5.

24 F. W. Stapel, Geschicdenis van Ncdcrlandsch-Indië (2nd ed.; Amsterdam, 1943), pp. 88-90.

25 Ibid., p. 96. 
were successively taken. ${ }^{26}$ Thus the Portuguese were expelled from Ceylon and at the same time lost their influence in Madura and Tanjore. Ceylon was henceforth protected against counter-attacks from South-East India, and in addition the Dutch could now take up the cloth trade in Madura which already had excited the interest of the English, whereas the pearl-fisheries near Manar and Tuticorin promised considerable profits. 27

It may be thought that this expedition of $1657-8$ was quite an achievement and although this cannot be denied it by no means fulfilled the ambitious program of the government at Batavia. The first object had been the conquest of Diu, the Portuguese possession on the peninsula of Cambay, in order to obtain a settlement in the north independent of Mogul authority.28 Cochin was another item on the list of desirable conquests designed to give the possessions in Ceylon greater security. ${ }^{29}$ The plan to attack Diu, however, had to be given up this time $\mathbf{3 0}$ and, as it turned out later, was never to be carried out. Cochin was not attacked either but in this case it was only a postponement.

The early relations between the Company and the Malabar coast went back to the beginning of the century when in 1604 a Dutch fleet anchored off Cannanore. The Zamorin of Calicut, with whose ancestor da Gama had established his first contact on Indian soil in 1498, showed his interest by inviting the Dutch for an interview. Mutual enmity with the Portuguese even led to an offensive and defensive alliance, but during the next period the Company had to pay attention to so many other problems that nothing much happened for many years. In connection with the trade system which the Dutch were developing Malabar was of far less immediate importance than Coromandel and settlements in Malabar which for one reason or another might be considered desirable were never a necessity to the Company. The main product, pepper, could be obtained at several other places, e.g. at Bantam, and the Company, moreover, lacked the power to expel the Portuguese from this area so near Goa where their forces were strongest. 31 After some time the Zamorin grew disappointed in the Dutch on account of their

26 Stapel, op. cit., pp. $103-4$.

27 J. Aalbers, Rijcklof van Goens (Groningen, 1916), p. 67.

28 Ibid., p. 103.

29 Ibid., p. 121.

30 Ibid., p. 131.

31 Comp. Terpstra, De Nederlanders in Voor-Indië, pp. 122-4. 
lukewarmness to give him efficient aid against the Portuguese and their ally, the raja of Cochin, and their indifference to avail themselves of his offers of trade at Calicut, and so he allowed the English to open a factory in 1616. But this turned out to be a failure when they proved no more capable of fighting the Zamorin's enemies than the Dutch. ${ }^{32}$

Whereas direct economic reasons for Dutch interest in Malabar originally hardly existed, other motives came into play gradually which made them look at the matter from a different angle. They noticed that the English bought Malabar pepper outside its production area elsewhere in India and used it for export not only to Europe but also to Persia where high prices were paid for this commodity. Consequently, prices on the European market in which the Dutch on account of their supplies from the Malay Archipelago were very much interested might be depressed. From the Dutch point of view there also was no reason why the English should undisturbedly be allowed to acquire an important share of the profitable export of Malabar pepper to Persia. Moreover, to the Portuguese this pepper together with the cinnamon of Ceylon formed the basis of their Asiatic trade. What could be a more attractive prospect than to deprive them of this basis when in the sixteenthirties the offensive against them in Indian waters was really launched? Anglo-Portuguese rapprochement becoming evident during these years provided yet an additional stimulus. ${ }^{33}$

In view of the new policy to send annual fleets for the blockade of Goa a place for victualling on the western coast of India was urgently needed. This was found at Vengurla in Bijapur territory somewhat to the north of Goa. Negotiations with the sultan of Bijapur were successful and the Dutch not only achieved their main purpose but it seemed as if they would also be able to establish regular and profitable trade relations with Bijapur. This trade, however, never came up to the Company's expectations. Here as elsewhere English and indigenous competition prevented the Dutch from obtaining considerable pepper supplies. ${ }^{34}$ Malabar became more and more desirable particularly so when occasionally the Company was unable to cope with the demand for pepper from Holland without endangering some channels of its expanding Asiatic trade. ${ }^{35}$ Yet, in spite of this the Company appeared

32 M. A. P. Roelofsz, De vestiging der Nederlanders tor kuste Mulabar ('s-Gravenhage, 1943), pp. 49-50.

33 Ibid., pp. 52-4 and 62-3.

34 Ibid., pp. 72-5.

35 Ibid., p. 77. 
reluctant to pour precious metals into the area so as to obtain pepper at prices which were rising owing to increased competition. Investigations of the consuming market of Malabar, however, turned out rather disappointingly, for the inhabitants seemed mostly interested in small supplies of cheap commodities of an inferior quality. ${ }^{36}$ In this respect trade to Malabar certainly did not promise a bright future, but the feeling began to prevail that the Company simply could not afford to discontinue this trade for fear the competitors should have free scope.

The situation changed for the better when, shortly before the truce between Portugal and the Dutch Republic became operative in the area, the basis was laid for a regular trade through contracts with several rulers, e.g. at Kayankulam where later, in 1647, the first factory on the Malabar coast was started. During the period of peace trade developed and it appeared that as long as the Dutch did not try to flood the market with commodities they could not get rid of elsewhere, but offered goods which were in fair demand they might even barter these for pepper. Opium and cotton purchased at Surat were in demand just as tin from Malacca, where the Company had acquired more or less a monopoly position, and of course spices. Besides pepper the Company bought mainly cardamom, especially for export to Persia, and areca for Surat. Although the Dutch did not at all like the system of giving advances to the Indian merchants for the purchase of pepper they often had to adapt themselves to this custom. Sometimes, however, the merchants with whom they traded regularly were willing to supply pepper without having first received the Company's goods of exchange. Occasional lack of buying-power of the Portuguese competitors explained this unusual attitude. 37

The resumption of hostilities with the Portuguese was attended by stagnation of trade to Malabar, but this was not of any great consequence, for just at that time the storehouses in the Malay Archipelago abounded in pepper. ${ }^{38} \mathrm{~A}$ few years later the situation changed in several respects. After the expulsion of the Portuguese from Ceylon in 1658 strongholds in Malabar were considered necessary for the protection of the island. Malabar's commercial significance increased at the same time as a result of a rebellion in an important production area of pepper in Sumatra. Finally the English displayed great activity along the western coast of India and established new relations

\footnotetext{
Rocloisz, op. cit., p. 85

37 Ibid., pp. 107-10, 114, 117, 131-4, 140, 145-6.

38 Ibid., p. 147.
} 
with the Zamorin in 1659.39 The start of the Dutch attack on the Portuguese forts in Malabar was not very successful, for although Quilon was taken in the end of 1658 it had to be evacuated within a few months when affairs in Ceylon and Madura required more attention. The rulers of both these countries had become alarmed about the obvious Dutch attempts to dominate the coasts in order to monopolize trade. Everywhere fear grew that as far as commerce was concerned supersession of the Portuguese by the Dutch worsened matters since the latter seemed to aim at a more complete monopoly which would interfere with indigenous commerce to a far greater extent.40 On the other hand, the Company became more keen than ever on expelling the Portuguese from Malabar when according to rumours peace between Holland and Portugal was drawing near and the English were to take over some Portuguese possessions.41 During a few years a special military effort was made and this resulted in the conquest of Quilon, Cranganore, Cochin and Cannanore between 1661 and 1663. These conquests meant the end of the struggle for power in Malabar between the Portuguese and the Company, for in 1663 peace was proclaimed.

From a military point of view the outcome apparently was a great success for the Company. In view of the loss of Formosa in the same period one may wonder, however, whether the military efforts were aimed at the right place. At any rate, the policy of expansion outside the Archipelago had now reached its limit and that of consolidation began to take its place.

On the face of it the economic gains resulting from the powerful position in Malabar were considerable. Everywhere contracts were concluded with Indian rulers and merchants which theoretically at least put the Company in possession of all the pepper at fixed prices that were lower than those paid before the occupation of the main forts. In practice, however, it soon became evident that it was impossible to enforce a monopoly to the same extent as in the Spice Islands. Even if the Company had had the naval power necessary for regularly patrolling the coast, the prevention of smuggling overland, especially to Coromandel, would always have remained beyond its power. The supply of goods had to be limited to small amounts if at least the same prices as elsewhere in India were to be made. Non-

39 Roelofsz, op. cit., pp. 163-4.

40 Ibid., pp. 169, 173, 181, 191, 212, 218, 231, 234.

41 Ibid., pp. $239-41$. 
compliance of this principle was dangerous, for the Indian merchants content with small profits and incurring few expenses were not slow in recognizing their opportunities of underselling the Company with its own goods at other places. For a similar reason the Company could not make as much profit as it would have liked on the pepper it purchased in Malabar, for inflating the selling-price in Persia, Surat or Bengal might result in an increased production of pepper in other areas of western India while the rulers who had to supply the pepper would become more and more unwilling to fulfil their obligations. ${ }^{\mathbf{4 2}}$

While there were therefore several circumstances which gave a less rosy outlook on the credit side than might have been expected at first sight, the other side showed some trends which were irreconcilable with the aims of a commercial undertaking. Garrisons had to be provided for the forts the upkeep of which devoured money. Reducing the forts in size might result in slightly less expense, but right from the beginning there was the danger that the overhead expenditure might grow out of proportion to the trade earnings. The political situation in Malabar contributed to turning this danger into reality.

A good deal of what had happened in the past in other parts of South India had not perturbed Malabar, the relatively narrow strip of land extending from $12^{\circ} 2^{\prime \prime} \mathrm{N}$. Lat. southwards between the Arabian Sea and the Western Ghats. Centralizing forces although not entirely absent had not been strong enough to maintain political unity, and on their arrival the Dutch, like the Portuguese more than a century earlier, found the area divided into many petty states. The more important kingdoms were Kolattiri, Calicut, Cochin and Travancore. Besides frequent temporary quarrels between different states there was the lasting hostility between Calicut and Cochin. Under Portuguese influence the raja of Cochin had grown in status and it is therefore not surprising that the Zamorin of Calicut had assisted the Dutch to some extent in their struggle against the Portuguese.43

As might have been expected the differences between the political objectives of the Zamorin and the Dutch came to the fore almost the moment the Portuguese had been expelled. The first hoped to extend his power southwards over the raja of Cochin, but the Company perceiving that its interests were best served as long as Malabar remained without a strong power would not allow him to do so. So the raja of

Roelofsz, op. cit., pp. 367-9.

43 P. C. Alexander, The Dutch in Malabar (Annamalainagar, 1946), p. 31. 
Cochin came virtually under Dutch protectorate and conflicts between the Zamorin and the Company became inevitable. When peace was finally re-established in 1717 the ultimate victory was on the Dutch side but this was only achieved after great military exertion following initial set-backs. The Company had been involved in other conflicts as well and the authorities in Holland and Batavia noticed with increasing anxiety that the military expenses in Malabar had grown out of proportion to the commercial results. It was therefore laid down that interference in local wars should be stopped. 44

The consequences of the tacitly acknowledged fact that the Company had aimed too high in Malabar were bound to come. Yet, they revealed themselves in an unexpected quarter when Travancore rose to prominence under Martanda-Varma. This raja gradually extended his power and, at first, the Dutch tried in vain by way of peaceful methods to restrain him from making further progress which gave him a hold on more pepper production areas. Later on the Dutch realized that a conflict was unavoidable unless they resigned themselves to giving up their policy of maintaining a balance of power in Malabar. In the war that followed the Dutch were worsted in 1741 and, in the end, realizing that there was no hope of ever getting the better of Martanda-Varma they came to terms with him. From a commercial point of view the conditions of the treaty finally concluded in 1753 were certainly not unfavourable to the Dutch, but politically they underlined the end of their supremacy in Malabar. Travancore was given a free hand to expand its power, for the Dutch had to promise to remain neutral in case the raja made war against other Malabar rulers. 45

In the north the Zamorin tried to take advantage of the Dutch decline and hostilities with the Company and the raja of Cochin arose. Peace between the Zamorin and the Company was restored in 1758, but the raja of Cochin had to apply for aid to Rama-Varma, nephew and successor of Martanda-Varma, in order to check the aggressor from the north. Rama-Varma saved him from disaster but at the same time did not fail to extend his territories at the raja's expense. ${ }^{46}$

Meanwhile, however, the character of the Company had shown signs of important changes the roots of which went back to the 17th century.

4t Alexander, op. cit., pp. 31-9, 45, 170.

45 Ibid., pp. 46-56. K. M. Panikkar, Malabar and the Dutch (Bombay, 1931), pp. 61-82. Alexander's account on pp. 47-8, mainly based on F. Day, The Land of the Permauls, or Cochin, its past and its present (Madras, 1863), is highly inaccurate as far as details are concerned.

46. Alexander, op. cit., pp. 71-3. 
During this century it became more and more evident that the field of operations between Arabia and Japan was too vast to be exploited by the Company solely with its own means. The Dutch might have been able to expel several of their competitors successively from the Moluccas, Macassar and Bantam, but they could not take the place of all those expelled. The result was a decline in the economic activity of several regions that came under Dutch control. The strict monopolistic lines along which the Company tried to exercise its control enhanced the depression, for the Dutch system of buying at minimum prices and selling the necessaries of life at maximum prices often resulted in a pauperization of the indigenous population. The people could no longer afford to buy Indian cloth and had to fall back upon manufacturing their own garments. Moreover, a policy of autarchy initiated in Mataram somewhat previously also contributed to this tendency. Thus the connection between the Indian textiles and the products of the Archipelago, so clearly recognized when the Company was still in its infancy, $\mathbf{4 7}$ was disturbed and this meant damage to the Company's inter-Asiatic trade system as a whole. Before the end of the 17th century profits from this trade began to decrease and the future seemed seriously endangered.48 The Company was, however, saved from early disaster by the development in Java where it had laid the foundation for becoming a territorial power by interfering in the internal politics of the two most important states, Mataram and Bantam. Under the influence of the rise in prices paid in Europe for colonial products such as sugar and coffee the Company began to stimulate agricultural production in the island and during the 18th century this aspect of the Company's enterprise, viz. compulsory cultivation, steadily grew in importance.49 A logical consequence was that the administration concentrated its attention more and more on events in Java.

Apart from these changes largely resulting from the Company's own

47 As e.g. in 1612 in that characteristic expression of the later GovernorGeneral Brouwer: The Coromandel coast is the left arm of the Moluccas and neighbouring islands since without its cloth, trade in the Moluccas is dead.

4.6 Comp. J. K. J. de Jonge, ed. of De opkomst van het Nederlandsch gesag in Oost-Indï̈, 6 ('s-Gravenhage, 1872), pp. LIII, LXXIII-V; ibid., 8 ('s-Gravenhage, 1875), pp. V-VI, CXXVI-VIII, CXXXII-III ; F. W. Stapel, Geschiedenis van Nederlandsch Indië, 3 (Amsterdam, 1939), pp. 511-4; H. J. de Graaf, Geschiedenis van Indonesië ('s-Gravenhage, 1949), pp. 207, 286.

49 Comp. B. H. M. Vlekke, Nusantara. A History of the East Indian Archipclago (3rd printing, Cambridge (Mass.), 1945), p. 145. 
policy, external circumstances also affected the Dutch trade system. During the 18th century both Persia and Japan, two of the cornerstones of this system, lost - although not to the same extent - much of their former importance to the Dutch, the first in consequence of internal unrest, the latter as a result of a restrictive Japanese trade policy. 50

In India the Company's position was influenced by the combined action of several factors, the increasing foreign competition, the lack of stability in the country's political situation and the decline of the Company as a military power. Until the beginning of the 18th century the Dutch could still hold their own economically as well as militarily, but they then soon started to fall behind their European rivals. The decreasing profits from the inter-Asiatic trade strengthened the tendency of reducing military expenses and in view of the changed character of the Company it need not surprise us that its naval squadrons, the keystone of its power in former days, virtually ceased to exist. During the great trial of strength between the English and the French about the middle of the century the Dutch often had even insufficient means to have their neutrality respected. Factories had to be closed or were destroyed and Dutch trade in Coromandel suffered heavily. Only once, in 1759 , a feeble attempt was made to turn the tide by sending a fleet to Bengal, but this badly executed expedition ended in a complete failure. Henceforth the Dutch had to resign themselves to the fact that the English had grown too strong. ${ }^{51}$ In order to see how the English obtained a leading position among the European nations in India it is necessary to have a look at the political development in the country.

By the middle of the 17th century Bijapur and Golconda were the only two of the five Muslim kingdoms in South India that had survived Mogul pressure from the north which had started in the late 16th century. For some time Bijapur and Golconda sought expansion in the direction of the disintegrating remnants of Vijayanagar but fresh Mogul attacks checked their southern advances. Meanwhile, however, a new power, that of the Marathas, had come into existence in western India to the north of Bijapur. Here Sivaji created an independent

wo Vlekke, op. cit., pp. 184-5.

51 Stapel, Geschiedenis van Nederlandsch-Indië (2nd ed.; Amsterdam, 1943), pp. 166-7. N. Mac Leod, „Uit de Geschiedenis der Oost-Indische Compagnie in de tweede helft der 18e eeuw", De Indische Gids, 32 (Amsterdam, 1910), pp. 1492 et seqq., 1605 et seqq. 
Hindu state which expanded rapidly in several directions. After Sivaji's death in 1680 the Marathas showed signs of discord and the Mogul emperor Aurangzeb, who in 1686-7 conquered Bijapur and Golconda, scored successes against them although he never gained a conclusive victory. The struggle for years on end proved too much for the Mogul empire which at the time of Aurangzeb's death in 1707 had lost much of its former vigour. During the next half-century independent states developed out of what had previously been provinces of the realm. The Mogul conquests in the Deccan formed such a state under the Nizam of Hyderabad. More to the south things had been developing along more intricate lines. The ultimate result of successive advances first by Bijapur and Golconda, then by the Marathas, and finally by Mogul armies was that by the middle of the 18th century the Nawab of Arcot, originally a Mogul officer and deputy for the Nizam, held the Carnatic and Madura. Tanjore had remained a separate Maratha state ever since Sivaji's half-brother had supplanted the former dynasty in 1675. Of the more important remnants of the Vijayanagar kingdom Mysore was the only part which had succeeded in maintaining its gradually acquired independence. This had been achieved in spite of manifold inroads by both Maratha and Mogul armies. 52

By this time, however, matters had become further complicated by the fact that the English and French Companies had started to play a new role in South Indian politics. For a better understanding of this new element it is necessary to consider briefly the development of these Companies. In doing so the stress will be laid on the English Company, because it had reached pre-eminence by the beginning of the period covered in this study.

In passing it has already been mentioned how events in the Moluccas and the Far East resulted in restricting the activities of the English Company to more western areas. But even previously there had been signs that the English, who lacked the financial background and the political incentive $\mathbf{5 3}$ of their Dutch rivals for building up a similar position in the East, looked upon the whole subject of eastern trade from a slightly different point of view. From the outset they seemed to consider the establishment of new markets for home manufactures at least as important as that of obtaining pepper and other spices. The

\footnotetext{
62 Moreland and Chatterjee, op. cit., pp. 243-4, $254-60$, 265. S. Krishnaswami Aiyangar in the Introduction to $\mathrm{R}$. Sathyanatha Aiyar's History of the Nayaks of Madura (Oxford Univ. Press, 1924), pp. 1-25.

53 See note 18 supra.
}

V.K.I. 31 
exclusion from the Moluccas, therefore, seems to have hastened rather than caused a development of affairs in which the English put the widening of direct commercial relations between Europe and the East first and foremost. ${ }^{54}$ Hence it is not so surprising to find that their first great effort to establish a factory in India was aimed at Surat where the possibilities of selling European goods were better than in Coromandel. It was also the English Company which opened up the market for Indian cotton goods in Europe. It is true that it did not make very much difference that the English were the first in a particular field of Indian trade, for during the 17th century the Dltch were generally not slow in following and surpassing them. Next to its limited resources another handicap of the English Company was that more than once it had to fight for its existence at home, where rival influences were encouraged to enter the field. The Dutch Company also sometimes came across jealous individuals, but these never got a chance of organizing a rival association in Holland.

Despite these and other difficulties the English Company maintained its place in Indian trade and succeeded in creating an increasing demand for English woollens and other goods. The return cargoes consisted mainly of indigo, cotton goods, saltpetre, pepper, silk and sugar. Part of the Indian products were re-exported to the Continent. Dutch expansion in the Malay Archipelago led the English Company to further concentrating its activities on India, and one of the results of this course of affairs was that in order to meet the growing demand for pepper more attention was paid to Malabar after the loss of the factory at Bantam in 1682. In course of time Tellicherry and Anjengo became important settlements for collecting pepper in Malabar and their existence furnished a clear proof of the failure of the Dutch policy of excluding the English from the pepper markets. At the close of the 17th century Bombay, acquired in 1668, Madras and Calcutta founded respectively in 1639 and 1690 , were on their way to becoming centres of the East India Company's main spheres of action. The beginning of the next century brought besides greater stability and unity at home, an initiative which was to have far-reaching consequences. Since about fifty years tea and coffee had come into use in England. More important than a revival of the trade to the Red Sea on account of the coffee was that the increasing demands for tea

54 Comp. W. Foster, England's Quest of Eastern Trade (London, 1933), pp. 6, 280, 321; Moreland and Chatterjee, op. cit., pp. 233, 236-8. 
resulted in the establishment of direct trade relations with China.55 In a way this meant the beginning of a reversed course of events in which the English gradually reconquered and extended their lost position in the Far East. Another feature of this period was a successful embassy to the Mogul court which returned in 1717 with mercantile conditions more favourable than those of any of the competitors. ${ }^{56}$ It was an important step on the road which half a century later would lead to British sovereignty in Bengal. On the whole the East India Company sought to maintain and expand its position by peaceful means although occasionally there were signs of a more offensive policy.

With the French the situation was completely different. It was not until well into the second half of the 17 th century that they made their first serious attempt to establish a strong position in the East. For some time their Company received full support of the state and some ambitious designs, which were principally directed against the Dutch, resulted in a royal naval force being sent to eastern waters. However, the whole enterprise turned out to be a failure which ended in the surrender of St. Thomé - taken by this French expedition in 1672 from Golconda which had expelled the Portuguese ten years previously - to the Dutch who subsequently restored the place to their ally Golconda.57 During the next decades French affairs did not flourish either. It was for instance only as a result of negotiations in Europe that Pondicherry, their settlement in Coromandel taken by the Dutch during the Nine Years' War, was returned to them.58 It would take another fifty years before the French could start playing a major part in South Indian politics. This happened when during the War of the Austrian Succession the French and English in India came into conflict. After the conclusion of peace both parties sought employment for their surplus troops by lending them to rival claimants to the thrones of Hyderabad and Arcot. In the subsequent struggle which went on for years other powers like Mysore, Tanjore and the Marathas

s5 Comp. Bal Krishna, Commercial Relations between India and England (1601 to 1757) (London, 1924), Chapters V and VI; W. Foster, "The East India Company, 1600-1740", The Cambridge History of the British Empire, IV (Cambridge, 1929), pp. 76-116.

58 S. Bhattacharya, The East India Company and the Economy of Bengal from 1704 to 1740 (London, 1954), p. 29.

57 S. P. Sen in The French in India. First Establishment and Struggle (Calcutta, 1947) deals in detail with this episode of French activity in India.

68 Stapel, Geschiedenis van Nederlandsch-Indië (2nd ed., Amsterdam, 1943), p. 122. 
also became involved. For some time it looked as if French influence would gain predominance in the whole of South India, but in the course of the Seven Years' War the English command of the sea turned the balance and in 1761 the end came with the French surrender of Pondicherry. When later on this town was returned to the French it was in ruins and had lost its fortifications and thus most of its former importance. 59

Another result of the struggle was the growing English influence over the successful claimant to the Nawabship of the Carnatic, Muhammad Ali, whose power was founded on English troops and funds.60 His Indian neighbour states were Mysore, Tanjore, a weak power in these days, and Hyderabad, where Nizam Ali usurped the throne in 1762. During the 18th century Mysore which had previously preserved links with the ancient Vijayanagar dynasty longer than any other part of the former kingdom, rose continually in status and prestige until a protracted struggle for the possession of Trichinopoly with Muhammad Ali ended in a Mysorean defeat. As a result the government which for years had been in the hands of two brothers as chief minister and commander-in-chief lost its stability and dissatisfaction spread particularly in the army. Haidar Ali, a Muslim adventurer who had proved himself an able officer, then rebelled and after a temporary set-back he succeeded by 1761 in making himself the undisputed ruler of Mysore.61 From the beginning his feelings towards Muhammad Ali were strongly antagonistic. In the north Haidar had two more potential enemies, the Nizam, and especially the Marathas whose invasions had become almost a regular feature of life in Mysore. It soon became clear that the new ruler of Mysore cherished ambitious designs. Although he began by turning his attention to the north, ${ }^{62}$ it was only a matter of time before he would try to realize his ambitions in other directions as well. The region to the west and south-west of Mysore with its many petty chiefs who were hopelessly divided among themselves formed an attractive field of action. It was here, in Kanara and

59 Comp. Moreland and Chatterjee, op. cit., pp. 270-2, 278-9.

00 Comp. H. H. Dodwell, "The Carnatic, 1761-84", The Cambridge History of the British Empire, IV, pp. 273-4.

61 Comp. M. H. Krishna, "The Dalavai family of Mysore", Bharata Kaumudi, I (Allahabad, 1945), pp. 347-67.

62 Allied with Basalat Jang, the Nawab of Adoni, brother and rival of Nizam Ali, Haidar invaded Maratha territory in 1761 (N.K. Sinha, Haidar Ali (2nd ed.; Calcutta, 1949), p. 38). 
Malabar, that the first contacts between Haidar Ali and the Dutch East India Company were to be established.

As the influence of the Company in South India never reached far inland, and as Mysore at no time had expanded to the coasts where the Dutch had their settlements, there had not been much contact so far. When in 1743 the Dutch Commander in Malabar handed over the administration to his successor he mentioned Mysore in his Memoir as a country with which the Company had no relations.63 According to Mossel, Governor of Coromandel, in his Memoir of 1744 Mysore was becoming rather an important country, but there is no indication whatever of relations between Mysore and the Dutch administration in Coromandel.64 Ten years later, however, a few letters were exchanged when Mysore in vain requested the Governor of Negapatam to mediate in the dispute with Muhammad Ali about Trichinopoly. 65

Before entering upon the subject of the present study a few lines should be added concerning the organization of the Dutch administration in South India. The highest post in the region was that of Governor of Ceylon at Colombo who also had Tuticorin and the other factories along the coast of Madura under his jurisdiction. Since 1690 Negapatam instead of Pulicat had been the seat of the chief of the possessions in Coromandel whose title had previously been raised from that of Director to that of Governor. The head of the Malabar settlements whose residence was at Cochin was called Commander (Dutch "Commandeur"). Although an administrator of lower rank than the other two he was, like them, directly subordinate to the GovernorGeneral and Council at Batavia, i.e. the High Government (Dutch "Hoge Regering"). Batavia was responsible for its actions to the authorities in Holland where the most important board consisted of seventeen directors, called "The Seventeen" (Dutch "Heren XVII").

There always existed a certain measure of co-operation between the administrations at Colombo, Cochin and Negapatam. In critical circumstances it occasionally happened that Batavia authorized Colombo to give advice or even instructions to Cochin and Negapatam.

\footnotetext{
63 "Memoir on the Malabar coast by J. V. Stein van Gollenesse. Composed in the year 1743 A. D.", Sel. Dutch Records Madras No. 1 (Madras, 1908), p. 14. 64 For Mossel's Memoir see Mackenzie Collection: Private No. 55, esp. pp. 98-9.

65 L. f. Cor., 1756, I, Vermont to Batavia, December 24, 1754.
} 


\section{THE DUTCH AND HAIDAR ALI, 1762-1766}

In February 1762 the Dutch Commander at Cochin, Weyerman, wrote to Batavia that the Zamorin of Calicut, who at that time still was at war with Travancore, was greatly to be pitied as several enemies had sworn his ruin. Weyerman based this information on a letter from Haidar Ali of 2 January 1762 in which it was said he understood that there was a close alliance between the raja of Cochin and the Dutch Company. The Zamorin had again invaded the kingdom of Cochin and, consequently, Haidar requested the Company to do something about it. He gathered that at present the Company had insufficient man-power, but he hoped this would soon be remedied so that the Zamorin might be expelled from Cochin. Haidar himself was also going to assist this country, for he had always maintained good relations with it. It was his intention, therefore, to march against the Zamorin with a considerable army by the 10th of January. The Company should also take the field and was requested to let him know when it intended to give battle. Finally, Haidar wrote that although Travancore had also come to the assistance of Cochin it would not be wise to depend too much on this country as it was quite possible that it would betray the common cause in the near future.

A few days later Weyerman replied to Haidar that the news of his assistance to Cochin was gratifying. The Company, however, was not in the position to do the same without having received special mandate from Batavia. As the Dutch were on good terms with both Travancore and the Zamorin Weyerman was not afraid of either of the two.66

Judging from this correspondence Haidar intended already in the very beginning of 1762 to expand his power in the direction of Malabar. However, his engagements elsewhere during which he met with far greater resistance than had been expected, 67 forced him to postpone

(4. f. M., 1763, I, Weyerman to Batavia, s. 1., February 25, 1762.

67 C. Hayavadana Rao, History of My'sore, II (Bangalore, 1946), pp. 411 et seqq. 
the execution of his Malabar designs. It is clear from Weyerman's reply that Haidar's letter failed to impress the Dutch who at this time certainly had no reason to regard him with special interest or suspicion.

Consequently, the events of the following year when Haidar started with taking Bednur, the capital of the Ikkeri state, in January 68 came to them as a real shock. This revolution in Kanara, as it was called, was considered so important that van Vechten, the Dutch resident at Cannanore, was ordered to get more details about Haidar Ali's life, his rise and qualities, and especially his future plans. The same information was sought from the interpreter whom the Dutch at that time employed at Basrur.69 In February this interpreter, de Souza, was visited by a representative of Haidar who told him that his master wished to live in peace with the Company and intended to further its trade. De Souza was invited to pay Haidar a visit at Mangalore. Without having received orders from Cochin de Souza left for Mangalore, as he later explained because he did not want to offend Haidar. This time the Mysorean ruler himself expressed the hope that the Company's trade in his dominions might flourish. On the same occasion he requested a few thousand muskets. When Weyerman reported these events to Batavia he had not yet replied to this request, but he intended to answer that he could not spare any muskets and that, moreover, he was not in a position to comply with a request like this without having received special orders from Batavia. In the same letter Weyerman inquired whether it was thought necessary to send special envoys to Haidar in order to compliment him, and to conclude a treaty concerning trade in his newly acquired territories, as well as the safeguarding of the Dutch interests in Malabar. A treaty was deemed necessary as it was generally assumed that Haidar would extend his conquests to the south as soon as an opportunity presented itself. In order to be prepared for any further development Weyerman asked for European military reinforcements. 70

Although at the time Weyerman had not yet written an official

68 In the "Historical Account of Nawab Hyder Ali Khan", Sel. Dutch Records Madras No. 5 (Madras, 1908) - hereinafter cited as Hist. Acc. -, p. 1, 16 January 1763 is given as the date of capture. Comp. Rao, op. cit., p. 447, from which it appears that there is some uncertainty as to the exact date. Rao takes 19 January.

69 In former days there had been a Dutch factory at this place which is called Barcelor on old maps.

70 L. f. M., 1764, I, Weyerman to Batavia, March 31, 1763; do., Weyerman to The Seventeen, October 15, 1763. 
reply to Haidar's request for muskets, he had found an opportunity for contact of a more informal character when informing Haidar that a representative of his had arrived at Cochin. Weyerman promised Haidar that the Company would make provisions for this person's journey to Ceylon, 71 but at the same time mentioned the ancient privileges the Company had in Kanara which he hoped would remain unaltered.

During the summer of 1763 information reached Weyerman that Haidar had occupied the country of Savanur and was marching against Sode. In September he was reported to be returning to Mangalore in order to march against Kolattiri. The chief of this country, however, seemed quite unconcerned, although it was said that Haidar was already sending rice for his troops to Cannanore in collaboration with Ali Raja, the Moplah chief residing at that place. ${ }^{22}$ In view of these reports a letter was drafted at the meeting of the Cochin Council on the 8th of October in which an exposition was given of the Dutch interests in Kolattiri, and of the fact that both the chief of that country and Ali Raja were still in considerable debt to the Company. In case he would obtain possession of Kolattiri Haidar was consequently requested to respect Dutch property, to promote repayment of these debts, and to permit the trade of the Company as before. This letter would be forwarded to van Vechten who should personally hand it over to Haidar at the border of Kolattiri as soon as his army marched against this country. Ten days later, however, van Vechten reported that rumours then said that the army of Haidar, who himself was still at Bednur, had been surrounded by a coalition near the borders of

71 Hist. Acc., p. 1. It seems probable that this person - in fact there were two persons, see note 102 infra - was sent to Ceylon to take up contact with Raza Ali Khan, son of Chanda Sahib, who at that time was staying in Ceylon and according to several sources joined Haidar in Kanara later that year (see Rao, op. cit., pp. 330, 349, but also pp. 27 et seqq. infra). Chanda Sahib, the candidate of the French for the throne of Arcot, was beheaded by a Tanjorean general in 1752 after his unsuccessful struggle with the other claimant Muhammad Ali, who was supported by the English.

72 Hist. Acc., p. 2. Savanur and Sode were states north of Mysore. The originally rather important state of Kolattiri in North Malabar had disintegrated into several petty states among which Kolattiri, Kottayam and Kadattanad. The Moplahs or Mapillas are the supposed descendants of Arab immigrants on the west coast (see N. K. Sinha, Haidar Ali, pp. 146-7; Rao, op. cit., p. 54; "Memoir of Commandeur Godefridus Weyerman delivered to his successor Cornelis Breekpot on the 22nd February 1765", Sel. Dutch Records Madras No. 12 (Madras, 1910) - hereinafter cited as Mem. Weyerman -, p. 47). 
Savanur. Reports from Goa of February 1764 said that Haidar's troops had taken Sode and had proceeded as far as the borders of Salsetta near Goa. The Portuguese had admitted the chief of Sode and had subsequently brought about an alliance with the Marathas. It was also reported that 200 French troops of Haidar had gone over to the Portuguese. Weyerman remarked that he would have been in a better position to report on these matters had not de Souza witheld all information. This interpreter appeared to be in close contact with Haidar but was not inclined to report on the state of affairs in Bednur. ${ }^{73}$ It was rather difficult to get reliable information on the situation because, as was rumoured, Haidar had forbidden on pain of death to spread news about his war operations.

In the meantime a letter dated 25 Octoher 1763 was received from Batavia on 14 December 1763, in which the Governor-General and Council advised Weyerman to keep up Haidar's fricndship, but to deny as far as possible his requests for arms and munitions. ${ }^{\mathbf{4}}$

Weyerman's later letters of 1764 contained few interesting facts. They only mentioned that Haidar was defending Kanara and Sode against the Marathas and rulers of other countries. In a battle not far from Goa's borders Haidar's army was said to have suffered heavy losses. Meanwhile the Portuguese were trying to find a solution for the quarrels between the raja of Sode and Haidar by sending a special envoy to Bednur, but there was difference of opinion with regard to the result of that mediation. The reason for this Portuguese step must be sought in the fact that for food Goa was mainly dependent on rice from Cannanore where trade-privileges had been taken away from the Portuguese after Haidar's arrival. In the spring of 1764 Ali Raja of Cannanore was received in great state in Bednur. In his company were also some envoys to Haidar's court sent by the Zamorin. ${ }^{75}$

In September Weyerman was succeeded by Breekpot who unlike his predecessor had no experience whatsoever of conditions in Malabar previous to his appointment as its Commander. ${ }^{76}$

73 L.f. M.. 1765, I, Weyerman to Batavia, s.1., March 28, 1764; do., Secret resolutions of the Cochin Council, October 8 and November 25, 1763.

74 Hist. Acc., pp. 3-4.

75 L. f. M., 1765, I, Weyerman to Batavia, s.l., April 15, 1764, and August 29, 1764 ; Mem. Weyerman, p. 54.

76 Breekpot had started his Company career as early as 1729 and had been employed in different posts on Java (see W. Wijnaendts van Resandt, $D c$ Gezaghebbers der Oost-Indische Compagnic op hare Buiten-Comptoiren in Azië (Amsterdam, 1944), pp. 194-5). On Breekpot's arrival Weyerman, who was suspected of corruption, was put under arrest. 
It was customary for the departing chief to write a Memoir meant to give his successor a clear picture of the general situation. Weyerman's Memoir dated 22 February 1765 was written at a moment when the result of the war between Haidar and the Marathas was still unknown to the Dutch. But Weyerman warned Breekpot that Haidar might be expected to proceed with his conquests on the west coast if he could stop the Marathas. In that case Weyerman thought his attention would first be drawn to Kolattiri. He probably intended to use Ali Raja in his conquest of that country. In the meantime the Company's trade in North Malabar suffered badly as a result of the events in Kanara. Whereas Japanese copper was formerly regularly sold there, while rice and sandalwood were bought, it had now become almost impossible to find buyers for copper. From Weyerman's remark that he had advised Batavia to conclude in time such treaties with Haidar as would be in accordance with the general Dutch interests, but that Batavia had enjoined that there should be no other dealings with him than would be absolutely necessary for the Dutch cause, 77 it becomes clear that Weyerman at least saw that there was quite a possibility of difficulties in the future. Whether he would have been the right person to conclude these treaties in case Batavia had approved of this policy is another matter. However this may be, Dutch policy on the Malabar coast prescribed from Batavia had been of a passive character since the peace-treaty with Travancore in 1753, and for the time being the High Government saw no reason to change this attitude for the sake of a new power which had just made its entry in this part of India. Moreover, the pursuit of a vigorous policy in Malabar would have been hindered during these years by the war the Company was waging against the king of Kandy. ${ }^{78}$ This is clear from the fact that reinforcements had to be sent from Cochin to Ceylon. Recruitment of sepays for this purpose seemed to be extremely difficult because Haidar enlisted all men in his territories for his war against the Marathas. Yet, finally some success was scored and about 100 men were enlisted in ... Mysore. 79

In February 1765 Breekpot received a letter from Haidar congratu-

77 Mem. Weyerman, p. 55.

78 Dissatisfaction about the Company's economic policy had led in 1760 to the start of a rebellion by the Ceylonese living in the coastal districts under Dutch administration. The king of Kandy soon openly took the part of the rebels and it was not until 1766 that peace was restored.

79 Mem. Weyerman, p. 33. 
lating the new Commander on his arrival at Cochin. Besides, Haidar asked him to send a capable person to Basrur in order to carry on trade as had been done in former times. Finally, he requested that an envoy of his should be provided with transport to Colombo.

Breekpot's reply was evasive. As soon as an opportunity arose the Dutch would avail themselves of his goodwill, but, as the Company did not intend to expand so far on this coast, the merchants of the north would be welcome to collect their merchandise from Cochin. As for the envoy, he would have been supplied with transport but for the fact that he had changed his plans on hearing that the person to whom he had to deliver his letters had left Colombo already. He had therefore returned to the north. 80

This person coming from Colombo had arrived at Cochin on 27 January 1765 and proceeded on his journey to Cannanore on the next day. He had travelled incognito as a captain of sepoys, but was Raza Ali Khan, 81 who is supposed to have joined Haidar Ali already in 1763. From the Dutch and English records it becomes quite clear, however, that Raza Ali Khan left Ceylon only in January 1765 . He had arrived there four years earlier when, after his flight from the besieged Pondicherry, he had reached Negapatam from where van Eck, at that time still Governor there, had helped him to proceed to Jaffna. At first the Council at Colombo did not feel happy about his presence on the island, because it was feared that it might result in a quarrel with the British, and this was to be avoided at all costs as the political situation on the island was already extremely difficult. It was therefore decided that Raza would have to leave Ceylon. ${ }^{82}$ But a year later, when van Eck, designated as Schreuder's successor to the Governorship of Ceylon, had arrived at Colombo, Batavia was informed that, subject to consent by the High Government, official permission to stay had been given to Raza, who had been at Jaffna ever since he came to Ceylon apart from a visit to Colombo. The feeling that he was an important person who at some time in future might be of great

40 L. f.M., 1766, I, Breekpot to Batavia, April 9, 1765. In another letter of the same date Breekpot made it clear that he had not made the suggestion that Kanarese merchants should collect goods at Cochin with the idea that it would be followed, but because this seemed to him the only way of neither accepting nor rejecting Haidar's proposal. He was forced to assume this attitude because of the Company's standing orders of neutrality ( $L . f . M$., 1766, III, Breekpot to Batavia, s.1., April 9, 1765).

81 Hist. Acc., p. 5. Comp. also note 71 supra.

82 L.f. C., 1762, I, Schreuder to Batavia, s.l., March 4, 1761. 
use to the Company, had prevailed over the fear of the English mainly, I assume, at the instigation of van Eck. 83 Batavia in fact agreed with this policy and even gave orders not only to treat Raza with distinction but also to assist him with whatever he would need.84

When in 1765 Raza left Ceylon for Cannanore exceptional measures were taken to keep his voyage concealed. On 12 January van Eck wrote a secret letter to Breekpot informing him that two sepoy-captains named Mahomet Chafer and Abdulleman were leaving with 12 sepoys by the shallop "De Standvastigheid" for Cochin and would proceed from there to Cannanore in order to recruit sepoys. The request was made to assist them as much as possible in carrying out their commission. 85 But on the same day a second secret letter was addressed by van Eck to Breekpot and Kroonenberg, the new resident of Cannanore who had just arrived from Batavia, in which he informed them that one of the two distinguished Muslims, passed off in his other letter as two sepoy-captains, was Raza Ali Khan to whose claims to the Nawabship of Arcot the Dutch Company was not indifferent. Raza had requested to be allowed to travel to Cannanore together with his brother-in-law, incognito, and under the guise of a sepoy-captain. Van Eck, who had addressed his letter to Kroonenberg as well, because he did not know whether Raza might not go straight to Cannanore without touching Cochin, asked for strict secrecy and requested that Raza should be given every assistance he might require, as far as this would not be incompatible with greater interests of the Company or neutrality with respect to other rulers. 86 A letter from Tellicherry states that Raza arrived from Ceylon at Mangalore in February 1765 and that Haidar presented him there with an elephant and a palanquin. 87

During the second half of 1765 there were recurrent rumours of an imminent attack on Kolattiri and the country of the Zamorin, but it was impossible to get a clear view of Haidar's intentions. ${ }^{88}$ An opportunity of sending Kroonenberg to Haidar's court was lost when on 25 October the Council at Cochin decided that it was impossible to

83 L.f. C., 1763, V, Schreuder and van Eck to Batavia, s.l., March 17, 1762.

84 L. f. C., 1766, III, Van Eck to Breekpot and Kroonenberg, s.l., January 12, 1765.

85 L.f.C., 1766, VI, Van Eck to Breekpot, s.l, January 12, 1765.

86 L.f.C., 1766, III, Van Eck to Breekpot and Kroonenberg, s.l., January 12, 1765 .

\$7 Bombay Abstract Letters Received, 2, 1762-1768. Tellicherry to Court of Directors, May 13, 1765.

88 Hist. Acc., p. 5. 
comply with a request made in this connection by the new Governor of Ceylon, Falck. Ceylon was still in need of more soldiers and Falck had therefore sent a sepoy-captain to Cochin to enlist sepoys in the north. He expected that Raza Ali Khan, on account of the way he had been treated during his stay on Ceylon, would be willing to use his influence with Haidar in order to get permission for the recruitment. Therefore, Falck requested that his letter should be delivered by Kroonenberg together with a present for Raza. The Council, however, was of opinion that in that case it would be necessary to give a large present to Haidar himself, and, moreover, the Company would be involved in considerable expense, for Kroonenberg would have to make the long journey to Bednur. Finally, Kroonenberg's presence was necessary at Cannanore and as he had met Raza before he might as well deal with the matter by letter. 89

On 22 December 1765 Kroonenberg forwarded a letter from Haidar to Breekpot in which he asked the Company to maintain friendship with Ali Raja. In his covering letter Kroonenberg reported that an agent sent by Haidar to Ali Raja had seized the opportunity to request from him, Kroonenberg, a few hundred muskets on his master's account, and that at long last he had given him fifty. A week later Kroonenberg wrote that at Mangalore a large fleet was being fitted out, that nobody knew for what purpose, but that it was said that Haidar was going to send 2,000 men to Ceylon to assist the Company there. The rumour of an imminent attack on Kolattiri had, however, disappeared.

In reply to Haidar it was stated that the Company was on good terms with Ali Raja and all the other well-disposed rulers. Kroonenberg was ordered to have this letter delivered to Haidar by a competent person who, on his return, would be able to report correctly.

During January 1766 there were strong rumours that Haidar would use his fleet to disembark troops near Calicut and Ponnani and, therefore, Breekpot requested Kroonenberg to inform him of whatever news he could get on this matter. However, before this letter reached Cannanore Kroonenberg had already reported that Haidar had arrived at Mangalore and that it was now accepted for certain that he would attack Kolattiri and the Zamorin, for which purpose Ali Raja was making all sorts of preparations. Kroonenberg asked whether he would be allowed to welcome Haidar on his arrival at Cannanore, pointing

s9 L.f.M., 1767, II, Proceedings of the Cochin Council, October 25, 1765. 
out that it might lead to bad relations if this was not done, especially as the British at Tellicherry had already sent presents and had nominated an envoy. Thereupon Kroonenberg was authorized to welcome Haidar and to give him presents to the value of about 500 guilders. He was instructed to point out to Haidar, in a most friendly way, the Dutch privileges in Kolattiri and its ruler's debts to the Company.

During the second half of February Haidar's army conquered the whole of the Kolattiri state. From the Dutch letters one does not get the impression that it had been a difficult task. On the contrary, they speak of the army meeting with no resistance at all. The population had fled and both Haidar and Ali Raja maintained strict discipline among their troops in order to lure the fugitives back to the country. Nevertheless, when one of the princes of Kolattiri, who at first had surrendered the province of Nileshwar without a blow, all of a sudden made a nightly attack on Haidar's army with 500 men and killed more than 100 soldiers, Haidar became so enraged that he gave orders to kill all Nairs. The result was a massacre and, consequently, a new general exodus of the population.90

On 7 March Kroonenberg paid his visit to Haidar who together with Raza Ali Khan had come to Ali Raja's residence at Cannanore. For the next day a second visit was arranged at Chirakkal, but when Kroonenberg arrived the army was already on the march and an elephant was given to the Dutch chief so that he could ride in Haidar's company to the next army camp. That night the Mysorean ruler affirmed the Dutch interests in Kolattiri, saying that he estimated the Dutch highest among the European nations. It proved to be more difficult to get a promise concerning the debt of the Kolattiri chief, but at last Haidar agreed to settle it provided his army should gain the desired victories. 91

In his report on this visit, Kroonenberg mentioned that Haidar had countermanded his orders to kill the Nairs. The army, which was said to consist of 50,000 men including more than 15,000 horse, and to have provisions for four months, had marched on to the neighbourhood of Tellicherry and was preparing to cross the river of Dharmapatam. On the other side more than 20,000 Nairs with batteries were awaiting

9o Hist. Acc., pp. 5-7;L.f.M., 1767, I, Breekpot to Batavia, s.l., April 15, 1766. "The Nairs are the feudal and military aristocrats of the West Coast" (Evan Cotton in his Foreword to K. M. Panikkar's Malabar and the Dutch, p. IX).

91 L. f.M., 1767, I, Breekpot to Batavia, s.l., April 15, 1766. 
it. Moreover, an army said to be more than 45,000 had taken up positions near the Mahi river. Just before closing his report Kroonenberg learnt that Haidar's troops had crossed the river of Dharmapatam and were marching towards Mahé to attack the Nair army near that place. The Nairs near the river of Dharmapatam had been utterly defeated, whereas Haidar's troops had only suffered a loss of about 800 . By the end of March the Nair opposition in Kadattanad was also overcome. On 13 April the Dutch chief of Chetvai reported that Calicut had been taken and that troops of Haidar had proceeded as far southwards as Ponnani, probably with the intention of marching against the raja of Cochin.92

On 17 April, two days after his arrival at Calicut, Haidar wrote a letter to Breekpot giving notice of this event and expressing his wish to live in peace with the Company to which he offered all trade in his dominions. This letter reached Cochin on the 20th, the same day that it was learnt that the Zamorin with five of his ministers had been taken into custody at Calicut. Previously, on the 14th, he had met Haidar and undertaken to supply him with 20 lakhs of rupees and 20 elephants. Soon afterwards the news came that the Zamorin had committed suicide by setting fire to the house in which he was detained.93

Even before the country of the Zamorin had been attacked, a period of great diplomatic activity had started at Cochin when Rama-Varma, the raja of Travancore, alarmed by the conquest of Kolattiri sent the Dellawa, his prime minister, in whose company was the Paljetter,94 the prime minister of the raja of Cochin, to Breekpot to discuss the situation. At first the Dutch Commander tried in vain to be excused. When he finally consented to a meeting on 21 March 1766, he told the ministers that the Company would pursue a policy of neutrality as far as possible, abstaining from anything that might offend Haidar. He advised them to do the same. Both of them would like to do so if

92 Hist. Acc., pp. 7-9. In a letter to Colombo Breekpot spoke of a second Mysorean army which had penetrated into the eastern parts of the Zamorin's dominions via Palghat (L.f.C., 1767, III, Breekpot to Falck, s.1., March 22, 1766). The Palghat Gap is more than 6,000 feet lower than the hills on its north and south (W. Logan, Malabar, II (Madras, 1887), p. CCCXCIII).

93 L. f. M., 1767, I, Breekpot to Batavia, s.l., June 12, 1766; Hist. Acc., pp. 9-10.

24 The proper names of these officials are the Dalava ("The Dutch in Malabar being a translation of Selections Nos. 1 and 2 with introduction and notes by A. Galletti, A. J. van der Burg and P. Groot", Sel. Dutch Records Madras No. 13 (Madras, 1911), p. 93) and the Paliyath Atchen (K. P. Padmanabha Menon, History of Kerala, I (Ernakulam, 1924), p. 512). 
only they could be sure of being left in peace. The raja of Cochin had been asked to supply the Mysorean troops with labourers who could be used in the war against Calicut, and in case the Zamorin would flee through his country the raja would have to extradite him. Breekpot gave some advice as how to act in these matters, namely, that some pretext should be put forward mainly in order to gain time. Finally, the ministers asked for a guarantee that the Dutch would assist their masters in case Haidar would attack them. This request put Breekpot in a rather difficult position. On the one hand, it was in his opinion still too early to reply in a negative way as the result might be an attack on the Company by Travancore. On the other hand, he had not the slightest intention of entering into a war for the sake of these states. He therefore pointed out that the invader had affirmed his friendship towards the Dutch and their allies, and that as soon as Haidar would arrive at Calicut deputies would be sent to discuss the Company's interests, in which connection Travancore and Cochin would be mentioned as allies. However, in case Haidar started hostilities the Company would act according to time and circumstances.

In fact, Breekpot did not think that Haidar would comply with possible wishes of the Company regarding these two states. He, therefore, reckoned with the possibility that the Company might be able to plead only for its own interests. In his secret letter of 15 April 1766 to Batavia he recommended concluding a treaty of mutual assistance with Haidar once he had conquered the Malabar coast. An alliance like this would neutralize the power of European competitors who also had their native allies. Breekpot was especially thinking of the relation between Muhammad Ali and the British, and his proposal was that the Dutch should enter into a similar arrangement with the Mysorean ruler. He thought that Haidar would almost certainly accept such a treaty as the operations said to be planned by him against Muhammad Ali and the English would cause a lot of trouble and make assistance by a European power desirable. Of course, a result might be war with the British but, as Breekpot put it, they could hardly blame the Dutch for acting in the same way as they themselves had done with regard to Muhammad Ali. He warned Batavia that by being idle the Dutch would lose whoever won, Haidar or Muhammad Ali. In the latter case the British would dominate the whole of the Malabar coast. Knowing his superiors' general attitude he added that also from a financial point of view the Company might gain by an alliance with Haidar. According to him this ruler had enough money to pay cash 
for ammunition and auxiliary troops. Of course it would mean that Cochin should be well garrisoned, but the expenses could be retrieved by the revenue of the districts which should be allotted to the Company..$^{95}$

Here Breekpot strikes a note rather uncommon in this period of the Company, and it is also notable that his previous attitude never pointed to the course of action now proposed. The question therefore may arise whether the ideas couched in the above-mentioned letter were entirely his own, or whether perhaps they were influenced or even called forth by suggestions from outside. As far as can be learnt from the Dutch correspondence no such suggestions had previously been made in writing to Breekpot, but they might have been put forward during one of those exchanges of views which had taken place, e.g. when Kroonenberg called on Haidar in the beginning of March. There is, however, not much likelihood of this having happened because in that case Kroonenberg would have mentioned it in his report of the meeting.

As we shall see later on, another way of contact between the Dutch at Cochin and Haidar Ali proved to be of some importance afterwards. This line ran via the influential Jewish merchants living near Cochin who carried on an important trade all along the coast. Although contact between them and Haidar Ali started already before the capture of Calicut - one of them, Ezechiel Rhabbij, had at one time obliged Haidar by sending him some medicine - yet it seems unlikely that their mediating influence was at work as early as all that. It was only after Breekpot had written his letter of 15 April to Batavia, that Ezechiel Rhabbij received a letter from Haidar inviting him to come to Calicut so that he might be entrusted with all the country's trade. His colleague Isaak Surion paid Haidar a visit immediately after the latter had arrived at Calicut, but this news did not reach Cochin until 20 April.96

It would appear, therefore, that the problem would have to remain unsolved but for the existence of another source of possible outside influence. In a secret letter to Batavia of 12 April 1766 Falck, the Governor at Colombo, gave as his opinion that the Company by keeping persistently to its peaceful principles came in danger of being held in contempt by the other nations and of losing benefits of trade one after another. At the same time the competitors seemed to be able to develop their trade and to let the Indian princes pay for the means

95 L. f. M., 1767, I, Breekpot to Batavia, s.l., April 15, 1766.

96 L. f. M., 1767, I, Breekpot to Batavia, s.l., June 12, 1766.

V.K.I. 31 
by which they made themselves powerful. This situation was reflected in the attitude of Muhammad Ali whose actions $\mathbf{9 7}$ seemed to have as their only aim to get into open dissension with the Dutch in order to be released from the obligation to maintain the few privileges which they still possessed. A certain La Beaume, who as Falck wrote, was well-known to the readers of his letter from other dispatches from Ceylon 98 and who had great experience in Indian trade, had offered Falck before leaving for Bombay, to bring about a treaty of friendship between the Dutch and the famous Haidar Ali, whom he considered to be a counter-balance against the power of Muhammad Ali. Falck, however, had restricted himself to writing a friendly letter to Raza Ali Khan, ostensibly to seek his aid in recruiting sepoys, ${ }^{99}$ but in fact, as he now stated, for the purpose of getting into touch with him as he was a favourite of Haidar. Falck was of opinion that to enter into an agreement with so mighty a prince might serve to safeguard the trade on the Malabar coast against Travancore. It might be taken for granted that Haidar would try to obtain troops and military stores, and, as Falck observed, the latter might just as well be supplied in future to Haidar instead of to Travancore's raja to whom they were sold now.

A defensive alliance with Muhammad Ali, on the other hand, would imply that the Company, so as to get something out of it, would have to assist him with troops against his enemies, just as the British did at his expense. There would then be a possibility of keeping the English

97 On 13 April 1766 Falck reported to Batavia that the approaches to the Dutch factories at Tuticorin, Punnakayal and Manapad had been cut off by people of Muhammad Ali, who had a dispute with the Company about the pearl-fisheries on Manar. Falck had the impression that British influences might have compelled the Nawab to measures detrimental to Dutch trade (L.f. C., 1767, I, Falck to Batavia, s.l., April 13, 1766).

98 As Falck had written in 1765, this French private merchant had for several years been a favourite of van Eck, Falck's predecessor. He had recruited some troops for van Eck on the Coromandel coast and as their commander he had been present at the looting of Kandy by Dutch forces in 1765. A number of men who were envious of La Beaume had later on accused him of having enriched himself more than anyone else. Falck had made inquiries into the matter and his conclusion had been that $\mathrm{La}$ Beaume had made a considerable profit at Kandy but that he had not behaved worse than the others, and that if he had enriched himself more than others this was not surprising for a cunning merchant (L.f.C., 1766, II, Falck to Batavia, s.l., November 10, 1765). In 1756 this same La Beaume had taken part in the English defence of Calcutta against Siraj-ud-daula (see R. P. H. Hosten, „Les Registres de l'église de Chandernagor (1690-1818)", Revuc historique de l'Inde française, 3 (Pondichéry, 1919), p. 156 for literature about him).

90 See p. 29 supra. 
troops away from the coasts opposite Ceylon by undertaking the protection of Muhammad Ali's districts in Madura and Tanjore.100

A few weeks later Falck wrote to Batavia that La Beaume had returned by the Dutch ship "De Drie Papegaaien" from Cochin with letters from Raza Ali Khan and Haidar Ali. The first had sent a present and his letter was friendly and comprehensible, but Haidar's letter was rather mysterious. ${ }^{101}$ Haidar wrote that he had learnt with pleasure from Raza Ali Khan about the behaviour, courtesy and other qualities of the Dutch, and from La Beaume about the praiseworthiness of Falck. He mentioned the fact that he was in need of elephants, horses and guns and that, therefore, he had asked that they might be held ready.102 Falck was now requested to send the elephants and horses which must have been held in readiness. 103

According to Falck's letter to Batavia, La Beaume had told him that Haidar, although hating the British, was afraid of them and therefore had given rather rich presents to some of them at Bombay and Tellicherry. He had even agreed to exchange pepper and sandalwood with them for munitions but the English kept their promises badly. Haidar dissembled his dissatisfaction in order to avoid that they might oppose him in his designs. According to La Beaume his aim was to found for himself and his descendants a mighty realm, and for that purpose to make himself feared by his neighbours by entering into an alliance with a European power. As he did not trust the British and noticed that the French had fallen so low that no help could be expected from them, he had now conceived the plan to widen his prestige by a defensive treaty with the Dutch. The conditions would be that the Company provided him with munitions on payment of either cash or pepper. Haidar was willing to assist with all his power in the protection of

100 L. f. C., 1767, I, Falck to Batavia, s.l., April 12, 1766. Falck regarded Tanjore as a tributary state of Muhammad Ali, who, indeed, since 1762 claimed tribute from its ruler (comp. Rao, op. cit., p. 656).

101 L.f.C., 1767, I, Falck to Batavia, s.l., April 29, 1766.

102 Although there are more obscure parts in Haidar's letter it was probably this passage which must have puzzled Falck most, for I have not found any reference to a request like this made by Haidar in this period. From L.f.C., 1764, III, Weyerman to van Eck, s.l., April 2, 1763, its appears that at that time two representatives had gone to Ceylon on a Dutch ship who professed to have been sent in order to buy some elephants. See also p. 24 supra where one person was mentioned. Preference should be given to the version of this letter which tends to be a more accurate source than Hist. Acc. which was compiled from the correspondence at a much later date.

103 L.f. C., 1767, I, Haidar to Falck, no date. 
the Company's possessions in South India in case the Dutch might get involved in a war with a European power. In this case mutual assistance was to be given, but the Dutch were not to meddle with his other enterprises.

Falck continued his letter with the remark that he had intended to leave the negotiations about a treaty like this -- in case Batavia was in support of it - entirely in Breekpot's hands because he was the man on the spot, but, according to La Beaume, Haidar did not like this idea because he wanted to keep the matter secret from the British and he therefore preferred to negotiate with the Ceylon Government. In Falck's opinion there was no risk for the Company in a treaty like this and he even thought it possible that Haidar might be induced to assist gratuitously in case of war between the Dutch and a European enemy if the Company ceded part of the districts which would be conquered. Most probably the Company's prestige in this part of the world would rise by the mere fact of such a treaty with a mighty ruler. Finally, Falck asked for early orders because Haidar might send a representative to Ceylon at the start of the navigation season along the Malabar coast. 104

The resemblance between Breekpot's proposal of a treaty of mutual assistance, put forward in his letter to Batavia of 15 April 1766, and the ideas developed in Falck's two letters is striking in several respects. It was La Beaume who influenced Falck and undoubtedly he also had the opportunity of influencing Breekpot in the same way, possibly already on his outward voyage but certainly on his way back.105 So there seems to be every reason to suggest that it was this French outsider who was largely responsible for Breekpot's proposal.

There are, however, a few interesting facts in connection with Falck's letters which should not escape attention. First, in his second letter of 29 April he failed to give the Governor-General and Councillors a picture of the latest development in Malabar, which, even if La Beaume might not have informed him, which is unlikely, must have been known to him from the letter Breekpot had written on 22 March.106 In that

104 L.f. C., 1767, I, Falck to Batavia, s.l., April 29, 1766. During the height of the south-west monsoon which blows from June to September the sea on the west coast of India is very stormy and in those days was practically unnavigable.

105 The ship „De Drie Papegaaien” on which he made the voyage from Cochin to Ceylon left Cochin on 6 April 1766. She reached Galle on the 18th of the same month (L.f.C., 1767, IV, fols. 1292 and 1464).

106 Falck replied to it on 19 April 1766 (L.f.M., 1767, I, Proceedings of the Cochin Council, May 25, 1766). 
letter Breekpot requested from Falck reinforcements of European soldiers, informing him of Haidar's attack on Kolattiri, Kadattanad, Kottayam and the Zamorin's country. Breekpot wrote that his policy was, above all, to protect the kingdom of Cochin, for its downfall would mean that Haidar's men came to settle around the Dutch forts and along the beaches, and this would certainly result in great difficulties. So far Haidar had given no reason to expect any harm from him, but he could not be trusted too much until he had given evidence that he was well-disposed towards the Dutch.107 Is it going too far to assume that Falck on purpose omitted this information from his letter to Batavia, because so far Breekpot had not given any sign that he too was of opinion that a settlement with Haidar should be the basis of the Company's policy? After all, Breekpot had already let him down once before on the issue of seeking a closer relationship with Haidar's circles when the proposal to send Kroonenberg to Raza Ali Khan had been turned down by the Cochin Council.108

Secondly, and closely related with the foregoing, there is Falck's remark about his original intention to leave the negotiations to Breekpot, which Haidar was said to have been opposed to on securitygrounds. If ever it was Falck's sincere wish to do as he wrote, he does not seem to have started executing this plan, for nowhere in the correspondence did I come across a reference to that effect. In fact it seems to me, that La Beaume's representation of Haidar's opinion as to where the negotiations should take place, was not unwelcome to Falck. That this representation was false was something he probably could not know at that moment. Actually there is nothing to support this view on Haidar's attitude, for there is no evidence either that he tried to evade talks with Breekpot, or that he desired to perform the negotiations secretly. It should be borne in mind, however, that Falck had just succeeded in bringing about peace in Ceylon by concluding the treaty of Kandy on 14 February 1766. This fact is, in my opinion, not unrelated with this attempt to use his diplomatic gifts once more in order to re-establish the Company's affairs in South India as well. We can be pretty sure that the result of his dealings with the war in Ceylon must have developed in the young 109 Governor strong feelings of selfconfidence and belief in the cause of the Dutch East India Company.

107 L.f.C., 1767, III, Breekpot to Falck, s.l., March 22, 1766.

108 Pp. 28, 29 and 34 supra.

109 Born at Colombo on 25 March 1736 (van Resandt, op. cit., p. 83), he was at that time only just 30 years old. 
At the same time La Beaume may have wished the talks to be held at Colombo so that he, the merchant who had had great influence with the former Governor, and was well on his way to have the ear of Falck, could play some part in it and gain by a successful result. From La Beaume's point of view it could only be useful if, at about the same time that Falck approached Batavia on the matter, a letter with the same ideas would reach the High Government from a different and quasi-independent side. To effect this aim the only thing he had to do was to persuade Breekpot to write such a letter, at the same time giving some plausible excuse why his own name should not be mentioned in this connection. He could easily prevent Batavia from deciding on account of Breekpot's letter that the negotiations should be carried on at Cochin by telling Falck that Haidar was against that idea.

My conclusion is that the change in Breekpot's attitude towards relations with Haidar is so sudden that it cannot well be explained without assuming some outside influence on his line of thought. Now this change took place at about the same time that La Beaume had the opportunity of meeting Breekpot, and so I take it that we have to see La Beaume's shadow behind the words in Breekpot's letter to Batavia of 15 April 1766.

On receipt of Haidar's letter concerning his arrival at Calicut 110 the Cochin Council decided to send the junior merchants Saffin and Zimmerman as commissioners to Calicut. According to the instructions of 23 April the purpose of their mission was: 1. To find out Haidar's intentions. 2. To learn his disposition towards the Company's affairs. 3. To seek further explanation of his letter regarding his wish of a lasting friendship with the Company and his offer of all the country's trade, especially sandalwood and pepper. The envoys were instructed to turn the conversation to these points and to sound Haidar about them without asking directly for an interpretation. In case he would explain himself he should be requested to give it in writing. In the instructions it was stipulated that it was also the commissioners' task to impress on Haidar the Company's privileges in the dominons of the Zamorin, viz. free trade throughout the country and the right to start factories for storing merchandise at Calicut and elsewhere. Confirmation of these privileges should be asked for. Then there was the point of mentioning Cochin and Travancore which as allies of the Company should be left in peace. If this point might not meet with a favourable

110 See p. 31 supra. 
reply it should be dropped for the time being. Finally, Haidar should be informed in a friendly way that the region between Chetvai and Cranganore was under sovereignty of the Company according to a contract with the Zamorin of 1717 . He should be requested to leave this region in peace. In case Haidar might broach the subject of the revenue of a district called the "Sandy land" near Chetvai, which revenue had been sequestrated since three years in connection with a debt of more than 12,000 rupees which the Zamorin owed the Company, he should be requested to leave this as it was until the Zamorin's debt had been settled. If Haidar did not raise the matter the envoys should not do so either. The same applied to some islands near Cranganore which had been given in pledge four years before, but were not fully owned by the Company.111

Accompanied by a suite of 25112 native soldiers Saffin and Zimmerman left Cochin on 24 April. Via Cranganore they reached Chetvai by boat in the morning of 26 April. From there two soldiers were sent on to Ponnani to inquire whether orders had been received from Haidar to accompany the mission on its further journey to Calicut. This arrangement appeared to have been made through the medium of Ezechiel Rhabbij, according to the report by one of the soldiers on his return in the evening of the 28th. As from now on the journey would be overland it was necessary to enlist coolies. When the group left Chetvai on the next day it had been increased by envoys of the Paljetter who had reached Chetvai the day before. They had requested to be allowed to join the party with an elephant meant as a present to Haidar. That same day Ponnani was reached and on 30 April part of the Company's presents to Haidar were dispatched by sea to Calicut, addressed to Isaak Surion. The Dutch envoys proceeded on their journey by palanquin and on the same day reached Tanur where on Haidar's orders they passed the night, like the previous one at Ponnani, with prominent Muslim merchants.

On 1 May the mission arrived at Calicut where the envoys were going to be the guests of Surion with whom Ali Raja was also staying. The sergeant of the soldiers was immediately dispatched to Haidar to seek an audience. This having been arranged for the next day at 5.30 p.m. the commissioners were informed by Surion that Ali Raja had urged Haidar to attack Travancore before the onset of the monsoon. It seemed, however, that Haidar wished to postpone the attack

111 L. f. M., 1767, I, Instructions for embassy to Haidar, April 23, 1766.

112 See the next note. 
till after the rains, and then turn his weapons upon Muhammad Ali at the same time in order to acquire the Nawabship of Arcot for Raza Ali Khan.

Next day while Saffin and Zimmerman were waiting in the palace compound Day, the English chief at Calicut, also arrived. The Dutch commissioners were seated on Haidar's right hand next to his prime minister, whereas Day took place on Haidar's left. After the Dutchmen had handed over their presents, mainly consisting of cloth and spices, and a complimentary letter from Breekpot, Haidar exchanged only a few words with them, being engaged most of the time in conversation with Day. The envoys supposed the subject to be the history of Kolattiri and they got the impression of a far from friendly interview. When Day, outwardly somewhat disturbed, had taken leave Haidar discussed several subjects with them till their departure at 9 p.m. when he promised to send some food to Surion who acted as interpreter. ${ }^{113}$

As had been arranged during the first audience the envoys returned to the palace in their palanquins next morning at 8.30. After having been received by Haidar himself, they were asked to sit down separately with Surion and the prime minister "Alisa Machan",114 and to inform him of the matters to be presented. On the advice of Ali Zaman Khan the point of mentioning Travancore as an ally of the Company

113 From an entry in the expense account of the mission it appears that the commissioners also had at their disposal a "Persian" servant who was employed as interpreter. Although there is a discrepancy in the figures of the commissioners' suite, this being given in the report of the embassy as a sergeant and 25 soldiers, and in the Proceedings of the Cochin Council of 4 June 1766, in which the report and the expense account were being dealt with, as a sergeant and 24 soldiers, it looks as if the sergeant and the "Persian" servant were one and the same person. The special services the sergeant was employed for at Calicut and the absence of an entry ,sergeant" in the expense account point to this fact. In any case there can be no doubt that the person who acted as their interpreter was with the envoys for the full duration of the journey, for he received payment for 28 days (L.f.M., 1767, I, Report of embassy to Haidar, May 25, 1766; do., Proceedings of the Cochin Council, June 4, 1766).

114 This person, described as having great affection for the Company with which he had been in contact for some time during a stay on the Coromandel coast, might be identified with Ali Zaman Khan, formerly an agent at Mysore of Muhammad Yusuf Khan and after Yusuf Khan's overthrow and death a close friend of Haidar (comp. Rao, op. cit., pp. 544-5. Yusuf Khan was a sepoy commandant who rebelled against the English and Muhammad Ali in 1763 and was executed after a protracted siege at Madura the next year). Neither in Rao nor in any other literature could I find any reference to the person who fulfilled the part of prime minister during Haidar's stay at Calicut. 
was dropped straight away. The prime minister undertook to present the other points mentioned before, and Haidar replied through Ali Zaman Khan that he was willing to yield all the country's trade to the Company or Ezechiel Rhabbij or whosoever the Dutch might wish to appoint if only the Company would be willing to supply him with his requirements. This could be settled in a treaty of friendship and everlasting peace. If the Dutch should want any more territory on the Malabar coast Haidar was prepared to cede it. Out of respect for the Company he would leave the raja of Cochin unmolested provided that two royal envoys were sent to discuss matters. In case his troops would have to pass through territory of the Company orders would be given for the same discipline to be kept as when marching through the home territories. Apparently Haidar deemed this to be a sufficient reply to the matters raised by the envoys and in his turn proceeded to put some questions to them through Ali Zaman Khan. In the first place he told them that he understood that the Dutch were having some dispute with Muhammad Ali which might make it necessary for the Company to take up arms against him. In that case he would be willing to assist the Dutch with 30,000 men and his navy on the understanding that they would reciprocate if necessary. Secondly, if he proceeded to the south, would the Company be prepared to assist him with 1,000 men in case he needed them? Further, free trade was allowed to the Dutch from Cochin to Basrur or as far as his dominions extended or in future might extend to. The factory at Basrur could be restored and in Ponnani or Calicut a Dutch factory might be established. Finally, Haidar asked for safe-conduct for two persons he intended to send to Cranganore where, as he said, the princes of Calicut with their treasures and elephants had fled into the pagoda.

The minister told the commissioners that Haidar wished to write a letter to the Governor-General at Batavia. The name of this dignitary having been supplied Ali Zaman Khan returned to Haidar who after a short while called for the envoys. Then both parties had to start afresh with the interpretation of the questions and replies which had been put on paper by the prime minister and the envoys. Thereupon Haidar ordered Saffin and Zimmerman to write to Breekpot about the points mentioned by him and to await the reply at Calicut. Their excuse that on account of the impending bad weather and their instructions they had to return after the meeting did not find much acceptance with Haidar who promised, however, to inform Breekpot of the reason for their delay. 
Shortly after 1.30 p.m. when the envoys had returned to Surion's home food was sent to them by Haidar. That night when they reported to the palace in order to receive the letters and presents intended for the Governor-General and Breekpot, they were told to call again next morning because of a visit of the English chief. So they did, and from then onwards they had to wait at Calicut until the reply from Cochin arrived.

Meanwhile, the envoys of the Paljetter were also received by Haidar and they asked for the retrocession of some districts between Chowghat and Ponnani which their raja had lost to the Zamorin. They also requested their country to be left in peace. Haidar agreed to these requests on condition that Cochin handed over the relatives, elephants and treasures of the Zamorin. The Cochin commissioners promised to inform the raja.115

During their period of waiting Saffin and Zimmerman sent their sergeant to Raza Ali Khan.11; For, at Cochin it had been suggested that the envoys should also pay their compliments to this influential person and should try to inquire secretly about Haidar's designs. Presents for Raza to the value of 245 guilders had therefore been taken along - the value of the presents for Haidar had been 559 guilders. 117 Whereas the commissioners themselves had paid him a visit on 4 May, thenceforth they apparently thought it sufficient to send their sergeant occasionally to Raza's place in order to get information about Haidar's intentions. But Raza Ali Khan gave the frank reply that he could not say anything as yet, except that Haidar had told him he felt more favourably disposed towards the Dutch Company than towards the other nations.

Although the reply from Cochin had not yet arrived, the envoys were again present at an audience in the palace on 11 May in the evening. This time the English chief asked for the resumption of the supply of sandalwood and pepper. The Dutch had already been told by Surion that Day had urged Haidar to sell all his sandalwood and pepper to the British, but that Haidar had replied on that occasion that he wished to sell to other Europeans as well. Now Haidar pointed out that not nearly enough had been given for the wood and pepper which had

116 L. f. M., 1767, I, Instructions for embassy to Haidar, April 23, 1766; do., Report of embassy to Haidar, May 25, 1766.

11 L. f. M., 1767, I, Report of embassy to Haidar, May 25, 1766.

117 L. f.M., 1767, I, Proceedings of the Cochin Council. April 21, and June 4, 1766. 
already been supplied. In the meantime his prime minister confirmed to the Dutch commissioners that Haidar would leave for his capital Seringapatam via Ponnani and Palghat within a week. Previously he would delegate his authority to the raja of Coimbatore, Madanna, who according to Surion had been in disfavour recently and had been compelled to pay a large sum in order to regain Haidar's favour.

When in the afternoon of 14 May Breekpot's reply dated the 9th reached the envoys, they had Haidar informed and requested a meeting next morning. They were invited, however, to come that same night. So they went to the palace where after some time representatives of the other European nations, English, French and Portuguese, also arrived. The letter meant for Haidar was handed over and in view of the presence of the others the Dutch requested to be allowed to return next morning. Haidar addressed all the Europeans and informed them that on his departure he delegated his authority to Madanna.

Next morning at 8.30 Saffin and Zimmerman found Haidar discussing sandalwood with Day. They therefore asked permission to state their case to Ali Zaman Khan, whom they told that a letter regarding the proposed treaty had been dispatched to Batavia and that the Dutch would certainly be willing to conclude a treaty, especially in view of trade. As soon as a reply reached Cochin it would be passed on to Haidar. In case Haidar would need 1,000 mon and ask for them, his request would be recommended to Batavia and he could be sure that the Dutch would get enough troops to assist him in that case. Finally, the raja of Cochin would be advised to send envoys.

Breekpot had written to the commissioners that they should approach Haidar incidentally whether, after all, there might not be a possibility of negotiations between him and Travancore. But in case they had the impression that this was not agreeable to him they could let Travancore matters take their own course, if only they informed him of the considerable sum Travancore had received as an advance on the supply of pepper. He should, therefore, be requested not to intervene with the collection of pepper at Kayankulam and Porakad. This point ought to be dealt with secretly lest Travancore should get to know about it.

This time the point of Travancore was raised with Haidar and he showed willingness to enter into negotiations with Travancore and Cochin on condition that the Company would mediate. The Dutch would have to induce both rulers to contribute to Haidar's war expenses and commissioners would have to be sent to settle this affair.

Breekpot and his Council also ordered the envoys to thank Haidar 
for his kind offer of aid against Muhammad Ali. As, however, no definite news about a dispute between the Company and that ruler had been received either from Negapatam or Colombo, it seemed preferable to await further particulars on arrival of which Haidar would be informed. Although an evasive answer should be given to the proposals of restoration of the Dutch factory at Basrur and trade-privileges in Haidar's possessions along the coast, Saffin and Zimmerman were expressly ordered to ask for recognition of all the Company's possessions in Malabar. It seems that Breekpot was not quite satisfied about the manner in which the envoys had been put off in the first instance with promises of expansion instead of receiving recognition of the present situation.

Haidar kept the envoys waiting till the next afternoon, 16 May, ${ }^{118}$ before he gave them their farewell audience. He then told them that on the 18th he would send Surion to Breekpot to discuss the matter of Travancore and Cochin. Surion would also take care of Haidar's letter to Breekpot for which Saffin and Zimmerman had been waiting.

After the sergeant had been sent to Raza Ali Khan for the second time and had returned with the message that still nothing could be said of Haidar's aims, but that Raza would write to Breekpot as soon as he got some news, the envoys left Calicut that very evening. In the early morning of the 19th they learnt at Ponnani, where they had stayed for the night, that Surion with envoys of Haidar had also arrived there during the night. Later, Surion told them that Haidar with his army had left Calicut on the 17th and that during his march in between Beypore and Tanur he had heard that the heir to the throne of Calicut had been crowned at Paravur by the raja of Travancore. Consequently, Haidar had been very angry. The commissioners returned to Cochin on 21 May. 119

Surion told Breekpot that Haidar's demand of Cochin was 400,000 rupees and 8 elephants and of Travancore 1,500,000 rupees and 30 elephants, but Surion was qualified to add secretly that the

118 When they first arrived at the fixed time in the morning of that same day, they were told by Haidar's servants that their master was being shaved and afterwards would take a bath and a meal. As it was a Friday, this is in corroboration with Miles translating a passage from the Persian work Ahwali Hydur Naik as follows: "On Tuesdays and Fridays, from the morning to mid-day, no one could enter his presence; for on that day he was shaved" (see M. H. A. K. Kirmani, The History of Hydur Naik, tr. by W. Miles (London, 1842), p. 507).

119 L. f. M., 1767, I, Report of embassy to Haidar, May 25, 1766; do., Breekpot to Batavia, s.l., June 12,1766 . 
Nawab would be satisfied with Cochin making a contribution of 25,000 rupees and 5 elephants and Travancore one of 200,000 rupees and 10 elephants. 120

When the envoys returned to Cochin commissioners of the raja of Cochin had already left for a visit to Haidar, but Breekpot knew that Rama-Varma had established closer relations with Muhammad Ali by paying a sum of 50,000 rupees and that he was preparing himself for war in alliance with Muhammad Ali and the English. Meanwhile, Cochin's raja had been summoned by Rama-Varma because, as Breekpot had heard indirectly, the commissioners of the raja would have received a favourable reply to their request in regard to retrocession of the territory formerly lost to the Zamorin.

Immediately after the return of Saffin and Zimmerman the raja of Travancore invited Breekpot for an interview. As there was some talk that Haidar might also want a discussion with him at Chowghat or even nearer to Cochin if that would facilitate keeping the meeting secret, Breekpot thought it wiser to stay at home so as to avoid jealousy on either side. It was therefore decided to send two envoys to Vaikam where the rajas of Travancore and Cochin were staying. This time captain de Saint Etienne, commander of the troops, and the writer Daimichen accompanied Saffin on the mission. On 26 May they left Cochin, being instructed to inform the rajas about what had been discussed at Calicut. At Vaikam Rama-Varma gave an exposition of his views, namely, that as a tributary of Muhammad Ali he could not accept Haidar's terms. He was willing, however, to send a delegation with a present to Haidar provided that the Company was prepared to send its own delegates along. For, if his commissioners would not get support from the Dutch they could not expect a kind reception from Haidar. His intention with this delegation was to propose reinstatement of the Zamorin and of the chief of Kolattiri under promise that they would contribute a sum of money. During these negotiations Haidar should depart from the Malabar coast with his army, because otherwise he might attack these rulers again after having received the money. The raja asked whether the Company would support these proposals and also whether, if all were in vain and an attack by Haidar followed, the Company would assist Travancore as it ought to do according to the treaty of 1753 . The envoys excused themselves by promising to report these proposals and questions to Breekpot. After-

120 L. f. M., 1767, I, Breekpot to Batavia, s.l., June 12, 1766. 
wards the raja of Cochin was also summoned to the meeting. He preferred to leave the matter entirely in the hands of the Company but he too would like to see the two rulers restored. On 28 May the commissioners returned to Cochin.

As Breekpot remarked in his letter of 12 June to Batavia, there was quite a difference between the language now used by Travancore, to which the raja of Cochin had to adapt himself, and that spoken at the conference of 21 March. Undoubtedly this was the result of the improved relations with Muhammad Ali and the British. It was said that Travancore had offered 1,200,000 rupees to Haidar for the restoration of the two rulers, but that this offer had been declined although the English at Tellicherry also would have strongly insisted on the reinstatement of the chief of Kolattiri. Rama-Varma's obvious aim was to bring more rulers to the same dependent position as the raja of Cochin. For Breekpot it was impossible to support Travancore's proposals as this would mean furthering the power and secret designs of Rama-Varma and also to a certain extent those of the British. Besides, no fruitful result could be expected from such negotiations because the gap between the different opinions was too wide. And what was even more important, if an agreement were reached Travancore and Cochin would expect the Dutch to advance the money due to Haidar.121

During the discussions with the Dutch envoys a letter to Breekpot had been drafted by Rama-Varma on behalf of the raja of Cochin. After having read it the latter determined to send it with the Paljetter to Cochin.122 When this person came to see him, Breekpot told him it was rather difficult to send a second embassy to Haidar. He added, however, that he was willing to support Travancore's cause by means of letters and to ask Haidar for a safe-conduct for the delegates. The Paljetter then replied that in that case Travancore would drop the idea of sending a delegation, and he requested the Company not to write about Travancore to Haidar. At the same time, however, he gave Surion a hint about Travancore's intentions and also on Cochin's willingness to contribute 5,000 rupees to Haidar and 1,000 rupees annually, provided it would get protection against its enemies. As Breekpot observed, he made this proposal without the knowledge of his dreaded patron, Rama-Varma, and out of affection towards his lawful lord, the raja of Cochin. ${ }^{123}$

121 L.f.M., 1767, I, Breekpot to Batavia, s.l., June 12, 1766.

122 L. f. M., 1767, I, Report of embassy to Travancore, May 29, 1766.

123 L. f. M., 1767, I, Breekpot to Batavia, s.l., June 12, 1766. 
So when Breekpot wrote to Haidar on 29 May in reply to his letter of the 16th,124 he only mentioned that delegates had been sent to the rajas of Travancore and Cochin, but he did not say anything about the result. ${ }^{125}$

A few days afterwards, on the 3rd of June, the Paljetter called again on Breekpot, this time accompanied by the Dellawa and another delegate. They repeated Rama-Varma's proposals and now desired a definite answer to the question whether the Company would assist Travancore in case of an attack by Haidar, and co-operate to restore the rulers of Calicut and Kolattiri. On this occasion they intimated that Rama-Varma clearly saw the dangers of his ties with the British. Breekpot pointed out to the delegation that the Company had showed itself to be well-disposed towards Travancore and that for the future its attitude would be to act in accordance with the circumstances.

Breekpot, meanwhile, got the impression that the main reason for the arrival of the Dellawa was to request 112,000 rupees in advance for the supply of pepper. This sum would be needed for a contribution to Muhammad Ali. As a refusal might result in the pepper supply being stopped and as the prospects of the supply were good, Breekpot agreed to the request. There would be no risk for the Company, for the main part of Haidar's troops had left the region during the negotiations with Travancore so that disturbances were not to be expected, at least not until the rainy season. What Haidar would do afterwards was still unknown, but Breekpot assumed that later in the year he would attack Travancore. In that case it would be extremely difficult for the Company to maintain its neutrality as Haidar's fleet might then be expected to enter into the estuaries commanded by Dutch forts in order to unload munitions and victuals for the army. Resisting it by force would mean war with Haidar, conniving at it difficulties with Travancore. Breekpot therefore asked Batavia for instructions and for military power to comply with those orders, or at least to be able to maintain the Dutch possessions and privileges. ${ }^{126}$

From the communications of the Dutch resident at Chetvai it appeared that Haidar, who had left Calicut on 17 May 1766, had

124 L.f. M., 1767, I, fol. 483, Breekpot to Haidar, May 29, 1766, says that it is in reply to Haidar's letter of the 7th of May. In view of its contents this is impossible. It was received at Cochin on the 21 st and had been written when the Dutch envoys were on the point of leaving Calicut, so most probably on the 16th.

125 L. f. M., 1767, I, Breekpot to Haidar, May 29, 1766.

128 L. f. M., 1767, I, Breekpot to Batavia, s.l., June 12, 1766. 
marched via Ponnani from where he proceeded eastwards on the 28th of that month after having sent ahead the main part of his army. About ten days later it was learnt at Cochin from Cranganore that the princes of Calicut were busy gathering an army of Nairs there. ${ }^{127}$ When there were about 1,000 men, they marched from Cranganore northwards. On the way more Nairs joined this band, so that it consisted of some 5,000 men when it arrived at about five miles east of Ponnani. They recaptured a fort in which they were able to maintain themselves, even when troops of Haidar tried to retake it. Shortly afterwards, information reached Cochin that the chiefs of Kadattanad, Kolattiri and Kottayam had gathered 25,000 men to the north of Calicut, had burned some mosques and killed a few Muslims. Ali Raja who was staying at Quilandi was prevented by these troops from moving any further. That the situation in this region was far from quiet was confirmed by a letter of the raja of Coimbatore to Breekpot of 10 June in which he mentioned the rebellion of the Nairs which he was trying to stamp out. Breekpot sensed that he had given this information on purpose, so as to make clear to the Dutch that this rebellion was being supported by the rajas of Cochin and Travancore. He replied therefore that the two rajas were no party to it. Meanwhile, the Dutch resident of Cranganore called on its raja to remonstrate on the admission of the princes of Calicut, and on the fact that they had been permitted to gather troops with which they had been marching through territory which was under the Company's jurisdiction.

On 30 June Breekpot received two other letters from Madanna, in the first of which he expressed his conviction that the rajas of Cochin and Travancore were no party to the rebellion in the dominions of the former Zamorin of Calicut, but that as they had admitted to their countries the heir apparent and his retinue who had entered into hostilities against troops of Haidar Ali, they would have to expel them if they wished to remain neutral. In the other letter dated 24 June it was stated that after Surion had delivered his report to Haidar he, Madanna, had been ordered to send someone to Trichur to negotiate with the rajas of Travancore and Cochin in Breekpot's presence. However, when Madanna was about to execute these orders he received

127 Hist. Acc., pp. 15-6. On p. 16 it is said that the information came from Travancore, but from the sequel it becomes clear that is meant from Cranganore. 
intelligence of the Nair insurrection in the country of Calicut, whereupon Haidar had countermanded his orders. ${ }^{128}$

Whereas some new implications tc which the Dutch sources point in respect of the origin of the Nair revolution will be covered in Appen$\operatorname{dix} I$, it seems advisable to consider here in more detail some aspects of the Dutch embassy to Calicut. The idea of sending a mission had originated with the Dutch at Cochin,129 for the general custom of their environment required as least a "de facto" recognition of the conqueror. As we have noticed before, 130 the other European nations acted in the same way and the Dutch were by no means the first to send envoys. Once the idea of complimenting Haidar by way of a special mission had been accepted, it was also decided to use this opportunity for a general discussion of the Company's interests. For this reason the commissioners received detailed instructions in writing and on the face of it the mission seems to have been a well prepared enterprise. But is this also true in fact? I do not think so. There are no indications that Breekpot and his Council sufficiently realized that such a discussion might entangle them in difficulties and even dangers. Unless there was a real urge on both sides to get to business, such a discussion on points of contact, which in future might easily turn into points of friction, was risky for the Dutch because of the possible exposure of the weaknesses in their position. Of course, they could not be sure about the line Haidar would take, but they knew that they themselves were not in a position to negotiate. Apart from a friendly message and some presents the envoys had nothing they could offer to Haidar. They came to ask, to ask for an explanation of his offer of friendship and trade, but above all to ask for confirmation of privileges. In the Dutch view this was far more important than the former as is clear from the fact that first the commissioners and later Breekpot and his Council were not prepared to give a straight answer to a favourable proposal in the field of expanding the Company's trade. Consequently, the queer situation presents itself in which the Dutch Company went in for discussions with a most powerful opponent without having anything to offer and without being willing to accept proposals from the other party.

128 Hist. Acc., pp. 16-7; L. f. M., 1767, I, Madanna to Breekpot, June 24, 1766.

129 Logan seems to have been of a different opinion when he wrote: "At Calicut Dutch commissioners met Hyder $\mathrm{Ali}$ at his request and discussed with him the terms on which he would be prepared to enter into an offensive and defensive alliance with the Hollanders" (Logan, op. cit., I, p. 411), but the sources I consulted do not corroborate his statement.

130 Pp. 30 and 43 supra.

V.K.I. 31 
On the other side there is Haidar who has just added new territories to his realm and who, far from having appeased his hunger for power, is thinking of extending his influence over the whole of the Malabar coast in one way or another. For the time being his aim during the discussions with the Dutch must have been to involve them in his schemes. From his point of view it seemed far more profitable to treat them in a friendly way than to drive them into the camp of his possible enemies. Now they might bring about acceptance of his proposals, or at least, uncertainty and indecision among the other rulers, whereas otherwise they might have backed those rulers in their resistance. This attitude of Haidar certainly did not mean that he was willing to meet all the Company's wishes for the sake of keeping its friendship without the possibility of getting something in return. Hence his proposals for an alliance in which both parties would have to share responsibility, and, pending such a treaty, only loose phrases instead of definite answers to questions put to him by the envoys.

It may be that an explanation of the casual way in which the embassy was sent is to be found in the fact that the Cochin Council had become too accustomed to discussions of the type that were regularly carried on with the rajas of Travancore and Cochin. These dealings were often not very important and of a general character only, and were always more or less on an equal footing. Perhaps Breekpot and his men could not dissociate themselves sufficiently from the idea that this time as well negotiations would be along the same lines. There may have been a certain amount of underestimation of the importance ${ }^{131}$ of the mission to Haidar and this would point to a lack of political judgement, since even if it had been merely a case of an embassy to a new ruler succeeding his deceased predecessor such an attitude would have been hardly excusable. It seems most likely, however, that more than anything else it was a time factor which influenced the Dutch line of thought: at the time of the mission bad weather was not far off and, consequently, there was no feeling of impending danger, as follows from Breekpot's letter of 15 April in which he wrote that

131 In this respect it is interesting to note that the value of the presents given to Rama-Varma during the embassy in May 1766 was 590 guilders, that is to say, more than the value of the presents given to Haidar at Calicut (see L.f.M., 1768, I, Breekpot to Batavia, April 6, 1767; the figure of 577 guilders quoted in this letter for the presents to Haidar includes part of the packing-charges, and is therefore slightly higher than the one given on p. 42 supra). 
he expected a conflict near Cochin only after the rainy season.132 Besides, it must be admitted that the directions received previously from Batavia to have as little contact with Haidar as possible, did not leave much choice for the Cochin Council in mapping out the policy for the mission. Even so, if under these circumstances playing for time seemed the best course of action the Dutch could decide upon, it is rather difficult to understand why the point of expansion of commerce was not stressed in the same way as the English did at the time. Fear of political strings attached to Haidar's offers of trade could scarcely have been a sufficient reason for aloofness in this respect, for it had become abundantly clear that confirmation of existing privileges also depended on acceptance of his political aims. The danger that lack of enthusiasm displayed on this particular point might easily be interpreted as indifference in general seems to have been overlooked.

Apart from a single exception perhaps, there is no indication in Breekpot's letters that he was not satisfied about the way the envoys had acquitted themselves in general of their task. In referring to their report he remarked that they had written down in great detail everything they had been discussing, doing and observing. ${ }^{133}$ Yet, Saffin and Zimmerman do not impress one as having been quite up to their task. For instance, I do not understand why they did not try to make more of the contact with Raza Ali Khan. Their behaviour in this case does not bear testimony to their diplomatic gifts. There seems to be no obvious excuse for not approaching this influential friend of Haidar's more often in person instead of sending a subordinate. In any other case their argument might have been that they needed an interpreter. But this rather weak excuse does not hold in this case, for during their first and only meeting with Raza they found that both parties were able to speak Portuguese. 134

In conclusion it may be said that neither the embassy to Calicut nor the subsequent discussions with the rajas of Travancore and Cochin contributed considerably to a lessening of the tension which had arisen from Haidar's attack on Malabar early in 1766.

132 L. f. M., 1767, I, Breekpot to Batavia, s.l., April 15, 1766.

133 L. f. M., 1767, I, Breekpot to Batavia, s.l., June 12, 1766.

134 L. f. M., 1767, I, Report of embassy to Haidar, May 25, 1766. 
CHAPTER II

\section{FROM ONE EMBASSY TO ANOTHER, 1766-1775}

With the start of the dry season of 1766 rumours became general again that Haidar would soon return from Coimbatore to the Malabar coast with a large army. It was supposed that after Raza Ali Khan, Haidar's son Tipu, Ali Raja and Madanna had succeeded in expelling the Nairs from Kottayam and Kadattanad, they would, combined with Haidar, attack Travancore. Meanwhile, Rama-Varma had requested another large amount of money from the Dutch. While insufficient pepper had been supplied for the previous advances which ran into 152,000 rupees, he had this time asked for 300,000 rupees and guns. This seemed to be an attempt to involve the Company in his affairs so as to make Haidar dissatisfied with the Dutch. It was finally decided to give 25,000 rupees with the promise of another 25,000 as soon as the old debt was paid off. 135

At the same time Haksteen, the Governor at Negapatam, reported to the Governor-General that the Nizam of Hyderabad, having noticed that Muhammad Ali was being used as a puppet by the English, had entered into an alliance with Haidar which was principally directed against Muhammad Ali, because Haidar wanted to proceed with caution against the English, although in his heart their sworn enemy. According to Haksteen's letter Haidar, who was being honoured by the Europeans who had served under him with the name of the "Eastern Frederick", aimed at restoring the Mogul empire to its former splendour. ${ }^{136}$

135 L.f. M., 1767, I, Breekpot to Batavia, s.l., October 15, 1766.

138 L.f. Cor., 1767, I, Haksteen to Batavia, s.l., October 15, 1766. C. Hayavadana Rao, History of Mysore, III (Bangalore, 1948), Ch. VI, gives detailed information about the different comparisons made in connection with Haidar. Rao's view about Haidar's objective, "an extended Mysore or rather a united South Indian Empire dominated by Mysore" (Rao, op. cit., p. 415), seems to be nearer the truth than the idea put forward by Haksteen. Actually, Haksteen was not well informed, since a treaty was only concluded during 1767 after the Nizam first had attacked Mysore (comp. Rao, op. cit., Ch. I, esp. p. 30). 
Meanwhile, Falck's letter of 12 April 1766 had been the basis of a discussion on the situation in South India by the Governor-General and Councillors at Batavia. The reply to Falck dated 23 May 1766 made it clear that as yet the High Government deemed it undesirable to take a decision regarding his proposals of a pact with either Haidar or Muhammad Ali. The reason given was that the general situation demanded a policy by which differences were being smoothed out as far as possible through all proper channels instead of being aggravated by entering into treaties. This was all the more necessary as such mighty armies were kept in the field all over India, so that it still remained a riddle what would be the outcome of all these warlike intentions. ${ }^{137}$

At their meeting of 21 July the men who bore the supreme authority of the Dutch Company in the East were forced to pay more attention to the matter, for by that time the letters from Breekpot and Falck respectively of 15 and 29 April had arrived. In his preliminary report van der Parra, the Governor-General, put forward that Haidar was an adventurer whose rise to the front might be checked suddenly, either by jealous nations or by internal rivalry. $\mathrm{He}$, therefore, did not seem to be the person with whom the Company at that time should conclude a treaty of commerce - in which the supply of munitions was especially to be included - let alone an offensive and defensive alliance. Only after he had defeated both Rama-Varma and Muhammad Ali a trade agreement with Haidar would be really advisable. It should then refer to Malabar and the coast of Madura if he had conquered the latter as well.

The second person to give a preliminary report on the matter was Schreuder, who had been Director of the Dutch factory at Surat from 1740 till 1749 and Governor of Ceylon from 1756 to 1762.138 Already a few years before, Schreuder had gone deeply into the problem of the Company's possessions and trade in this area when he wrote his Secret considerations on the state of the Company on the Malabar coast,139 and on that occasion, and indeed, also later on

137 Hooge Regeering Batavia 589, Batavia to Falck, Extract from s.1., May 23, 1766.

138 W. Wijnaendts van Resandt, De Gezaghebbers der Oost-Indische Compagnie op hare Buiten-Comptoiren in Azië, p. 79. According to van Resandt Schreuder was Governor of Ceylon until 1761. It was, however, not until March 1762 that he handed over the administration to van Eck.

139 These considerations dated 16 December 1763 are to be found in L.f.B., $1764, \mathrm{~V}$. 
he proved himself to be an advocate of a policy of concentration on a few points and demolition of the other forts and posts. It is, therefore, more or less surprising to read the remarks he made at this time. According to him it was conceivable that the growing power of the British and their allies would result in their gradually expanding control, so that perhaps in the end there would remain no ruler with sufficient courage or money to resist the English and Muhammad Ali in alliance with the Dutch or with any other European nation. It was, he thought, high time that a European power joined one of the remaining mighty native powers in order to check the progress of the British. And as no European nation apart from the Dutch could be considered powerful in India, it was obvious that the Dutch, who suffered most from the growth of the privileges of the English, should resolve upon this step. Haidar, the ruler of Kanara, ${ }^{140}$ seemed to him to be the right person for this purpose. He had sufficient financial and other means. The question was, however, whether the Dutch were able to support him with adequate troops. This could only be done by denuding Ceylon, Java and the Spice Islands of troops which would imply too great a risk. Unless, therefore, Haidar would be satisfied with military stores on payment of pepper, the project could not be realized.

Thereupon it was decided to communicate to Falck that the High Government dropped the idea of a pact with Muhammad Ali altogether, and also could not resolve to enter into a closer relationship with Haidar than the conclusion of a commercial treaty. And as to this treaty Falck was instructed to act in consultation with his own Chief Administrator, 141 the Governor of Coromandel and the Commander of Malabar. But they should not even proceed with this treaty before the Nawab of Arcot and the raja of Travancore were brought to Haidar's submission, or at least became his tributaries. ${ }^{\mathbf{1 4 2}}$

The point of view taken by Schreuder on this occasion seems far more realistic than the main theme of van der Parra's considerations which did not go much farther than speculating on the possible fate

140 As is more often the case in the Dutch records of these years, Haidar is not spoken of as the ruler of Mysore but of Kanara. For another example see p. 75 infra.

141 Dutch „Hoofdadministrateur". "We might say that this officer was at the head of the trade department", M. W. Jurriaanse. Cataloguc of the Archives of the Dutch Central Government of Coastal Ceylon 1640-1796 (Colombo, 1943), p. 15.

142 Secret resolutions Gozernor-General and Councillors, 1766-73, July 21, 1766. 
of a usurper. From Schreuder's words it is in the first place interesting to note that there was a feeling among the Dutch that, apart from the British, they were at that time the most powerful European nation in India. The fact that the opinion of La Beaume reported in Falck's letter had pointed in the same direction may not have been entirely without influence on Schreuder's line of thought. But it should also not be forgotten that the French prestige in the India of 1766 was very low indeed compared with that of some ten years before and also with the later period, when in the war of the 1780s the French had at least a chance of regaining influence by their sea-power while the Dutch had none. Personally, I therefore do not think that this feeling among the Dutch was as wide of the mark as one would be inclined to think if attention is paid only to later events. The most important point of Schreuder's view is, however, his clear insight that the Dutch could not be of much use to Haidar unless they were prepared to change the whole of their defence system. That the troops needed for such a purpose could not be spared is not surprising if it is taken into account that at the same time it was considered necessary, principally because of fear of penetration by British traders, to establish the Company's power in East Java on a firmer basis.143 While not disputing the obvious line of thought that affairs in the Archipelago should have preference to those in India one may query, however, whether the policy recommended to Falck was ever feasible. The idea to limit relations with Haidar to the commercial plane in itself already betrays some lack of realism, but it could perhaps to some extent be justified with him by stressing the trading activities of the Company. The stipulation, however, not to start negotiations before Haidar had become master of practically the whole of South India not only made such an explanation impossible but seemed sheer self-delusion. For how could the Dutch have any hope of being recognized as an equal partner once he had reached his aims? The men on the spot, who anyhow faced an extremely difficult task, might still have had a chance of coming to an understanding with him if it had not been for this extension of the non-committal policy into the field of commerce. Now the very weak nature of the decision that was reached and its halfheartedness were bound to put them in a hopeless position.

In October 1766 Falck forwarded Batavia's directives to Breekpot,

143 Comp. M. L. van Deventer, ed. of De opkomst van het Nederlandsch geaag in Oost-Indië, XI ('s-Gravenhage, 1883), pp. I-III. 
and from the next letters written by him to Breekpot and to The Seventeen it appears that, as was to be expected, he was very disappointed about the development. In his letter to the first he reported that La Beaume, who had recently returned from Negapatam to Colombo in order to learn Batavia's reply, had been staggered at the response. He had clearly intimated to Falck that Haidar's favourable impression of the Dutch might easily take a turn to the detriment of Dutch interests. Falck had with difficulty persuaded him to leave once more for Malabar in order to smooth the matter over with Haidar. Falck himself was obviously not very confident of the success of this mission, for he went on to say that French officers who had served under Haidar had often told him that he was a man of impetuous pride, and therefore he, Falck, was apprehensive of the future. Undoubtedly Haidar was going to profess that at present there was no war between him and any of the Company's allies so that there was no reason to refuse to sell him arms. Batavia had written not to enter into a treaty of commerce before Haidar had subdued Muhammad Ali and RamaVarma. Nevertheless, he was not inclined to think, Falck wrote, that it was Batavia's intention to forbid the conclusion of such a treaty if Haidar were not at war with either the Nawab of Arcot or Travancore's raja, and, therefore, had no opportunity of subduing them. The purport of Batavia's instructions seemed to be only that the Dutch should practise strict neutrality between belligerents, and in peace-time neutrality was irrelevant, according to him. Hence he had shipped 2,000 flintlocks to Cochin so that Breekpot might use them as soon as he saw his chance, with a view to consolidating the Company's interests, either by openly giving them to Haidar in exchange for pepper or, preferably, by disposing of them to a native merchant without mentioning Haidar's name.144

In the letter to The Seventeen of 30 January 1767 Falck reported that he had sent replies in fricndly and general terms to the letters of Haidar and Raza Ali Khan and, in accordance with Batavia's express command, had refrained from negotiations. As to what had been done meanwhile to prevent Haidar from becoming angry about the weak reaction to his professions of friendship Falck referred to his letter to Breekpot of 27 November 1766. He further observed that if the news from Coromandel that the English had entered into an agreement with Nizam Ali were true, Haidar probably would have to suspend

144 L.f. C., 1767, IV, Falck to Breekpot, s.l., November 27, 1766. 
his bellicose designs against Muhammad Ali. In that case the latter's consolidated position would cause great regret to the Dutch. ${ }^{145}$

Having seen with what quibbling interpretations Falck had done his best to ward off the danger resulting from Batavia's orders, we must now once more turn our attention to the seat of the High Government. Batavia's unwillingness to enter into closer relations with Haidar meanwhile did not prevent the High Government from observing a positive aspect of his rise as well. This is illustrated by a remark in a letter of 21 October 1766 to The Seventeen, where it is stated that the gallant Mysorean Haidar Ali had already set bounds to Travancore's ambition.146 At about the same time new directives were formulated regarding a special problem which had been a subject of correspondence between Batavia and Cochin for some years, namely, the future of Cannanore. On the basis of Schreuder's Secret considerations of 16 December 1763 instructions had been received by Weyerman during 1764 to reduce the Company's affairs and establishments in most of the outstations. ${ }^{147}$ Several small posts had been given up altogether, but first Weyerman and later Breekpot were rather reluctant when it came to abandoning the more important settlements like Cannanore with its fort. Their point of view was that this would do the Company a good deal of harm as such a measure of economy would be interpreted by the Indian powers as a sign of weakness. Nevertheless, a start had been made by sending superfluous military stores from Cannanore to Cochin, but in view of the threatening political development Breekpot had thought it better to take no further action. Thereupon he had been asked by the High Government to state reasons for keeping on the fort and to give advice as to the best way of parting with it if it was not considered a necessary possession. After having consulted Cannanore's resident Kroonenberg, Breekpot could give only one argument for keeping on Cannanore - the collection of pepper. And even for this reason the fort did not seem to be really necessary since Haidar Ali had conquered Kanara, and a factory with a warehouse would be quite sufficient under the new circumstances. The best way to part with it was to offer it for sale to Haidar. On 31 October

145 L.f.C., 1767, IV, Falck to The Seventeen, January 30, 1767.

146 L. f. B., 1767, I, Batavia to The Seventeen, October 21, 1766.

147 Off and on this problem had been cropping up in the correspondence almost from the moment the Dutch had conquered the Portuguese settlements in Malabar. Van Dam mentions letters written about it in 1681 and 1683 (Pieter van Dam, Beschryvinge van de Oostindische Compagnie, Tweede boek, deel II, ed. F. W. Stapel, p. 312). 
1766 Batavia replied that for the time being Cannanore should be left in its present state, but if Haidar seemed inclined to take it over for a good price cautious negotiations could be opened with him when due occasion arose. 148

The attitude taken in this case together with the fact that at the same time renewed orders were given to destroy the forts of Chetvai, Quilon and Cranganore help to better visualize the aims of Batavia's policy regarding Malabar. The High Government wished to liquidate most of the territorial possessions on this coast as soon as possible in order to save large expenses. In doing so it was fully prepared to give up political aspirations instead of which it wanted to concentrate all energies and means on the commercial side of the settlement. The process of transition from a settlement with wide-spread territorial possessions into one with some trading-posts around it had been held up by the persons who had to execute it, but it continued to govern the thoughts and actions of the members of the High Government to such an extent that they became unable to see beyond it. To them it was an established fact that the future of Dutch interests in Malabar, if any, lay in the field of trade, and not in that of political power. This went even so far that they kept their eyes closed to the political events which were taking place. They could really only think in terms of a commercial treaty with Haidar, and not in those of an offensive and defensive pact. Theoretically, a number of arguments could be adduced in support of their point of view, but what they did not recognize or, at least not sufficiently, was the fact that it was practically impossible to realize the radical transition which they had in view at a time when as a result of the Mysorean advance the political situation in Malabar had become more complicated and unsettled than ever before. To insist under such circumstances on dismantling strongholds as Chetvai and Cranganore situated near the frontier between the zones of interest of Mysore and Travancore amounted to disturbing an unstable balance and could easily lead to repercussions in the form of hostile actions by either of these two powers. If it had been thought unwise to carry out this policy of Batavia in former days because the Company was too deeply involved in Malabar politics, it was certainly

148 "Memoir of the departing Commander Cornelius Breekpot delivered to his successor the worshipful titular Governor and Director-elect Christian Lodewijk Senff on the last day of February 1769", Sel. Dutch Records Madras No. 7 (Madras, 1909) - hereinafter cited as Mem. Breekpot -, pp. 3-5; L.f.M., 1767, I, Breekpot to Batavia, s.l., April 15, 1766. 
not the right moment for doing so now. The lack of vision of the High Government that their policy, which under different circumstances might have had a sound basis, was badly timed made things particularly difficult for the men on the spot. To them it was incomprehensible why exactly at this juncture a policy should be implemented the pros and cons of which had been a subject of discussion for more than eighty years. They might try to avert the dangerous consequences of Batavia's policy by obstructing its execution, as Weyerman and Breekpot did, or by interpreting it in their own way, as Falck did, but they were unable to get it changed at its root. The result therefore was an ambiguous course of action which was, moreover, frequently paralysed whenever Batavia delayed reacting to suggestions or proposals. Then, in a way, there was still another potential cause for trouble in the fact that the opening of negotiations on a commercial treaty had been commissioned to Falck, whereas in other matters related to it instructions had been given direct to Breekpot.

At a meeting of the High Government on 11 November 1766 Breekpot's letter of 12 June, in which he asked for instructions as to his future attitude with respect to Haidar, was dealt with. The letter from Haidar to the Governor-General received at the same time had not yet been translated. Furthermore, there was a second letter from Breekpot of the same date, in which he requested 1,000 flintlocks to be sent in behalf of Haidar. The opinion expressed at the meeting was that the situation still remained highly unsettled, although Haidar apparently felt welldisposed towards the Company. As there had not been a change of such nature that the High Government, conformably to the resolution of 21 July, could comply with Breekpot's request, it was decided to decline it under the pretext that it had been received too late for the ship which was to leave for Malabar within a few days. It should be pointed out to Breekpot once more that Falck had been instructed on what conditions he might enter into a treaty of commerce for the supply of munitions in exchange for pepper. It was decided to add that the High Government therefore had no doubt that Falck would approach him according to the exigencies of the case. But as soon as Travancore might be defeated by Haidar Breekpot should consult Falck in case he was of opinion that the delivery of 1,000 flintlocks could not well be delayed. He could then take them from the 2,000 which were being dispatched in behalf of Travancore.149

149 Secret resolutions Governor-General and Conncillors, 1766-73, November 11, 1766. 
Batavia, clinging to its former decision on the lines along which a treaty of commerce should be entered into, did not even go into Breekpot's question how to act in case Haidar attacked Travancore. With this unsatisfactory reply to his letters Cochin's Commander was to face future developments.

The rumours of an imminent attack by Haidar on the kingdoms of Cochin and Travancore ended when suddenly in the beginning of 1767 it was reported that Haidar had left Coimbatore for Seringapatam in order to watch the movements of the Marathas. His fleet of 28 vessels anchored off Cochin on 20 February and two official messengers paid a courtesy visit to Breekpot. Madanna, who had been reinstated as Haidar's lieutenant at Calicut, twice made a request to be supplied with powder and shot, but Breekpot pretended that there was nothing left, because cash and not pepper was offered in return.150

Meanwhile, a letter and presents made in return to Haidar by the Governor-General had arrived at Cochin, but as nobody knew where he was at that time Breekpot informed Madanna about it and asked to let him know Haidar's whereabouts. ${ }^{151}$ Madanna replied that the letter and presents should be forwarded to him and promised to send them on. Breekpot agreed and wrote in April to Batavia that they were going to be sent on to Ponnani at the first opportunity. 152

On the other hand, Travancore's diplomatic activities brought about anxiety among the Dutch at Cochin. Rama-Varma had summoned Cochin's raja and the pretender to the realm of the Zamorin, as rumour had it, in order to deliberate how to retake from Haidar the Zamorin's territory and to declare war on him, at the same time forcing the Company to come in or advance money. As Breekpot observed in a letter to Falck, the Dutch would have to refuse this but were too weak to offer resistance if great compulsion were exercised.153

In March 1767 La Beaume arrived at Cochin with the news that he had met Haidar at Seringapatam. The Marathas had invaded the northern districts of Mysore and Nizam Ali was on his way to attack Haidar as well. According to La Beaume Haidar was not at all dismayed and intended to make peace with one of the two enemies through money and to make war upon the other with the assistance of the first. In the meantime matters on the west coast took an un-

150 L.f. M., 1768, I, Breekpot to Batavia, s.l., April 6, 1767.

151 L. f. M., 1768, II, Breekpot to Madanna, February 11, 1767.

152 L.f. M., 1768, I, Breekpot to Batavia, s.l., April 6, 1767.

153 L.f.C., 1768, II, Breekpot to Falck, s.l., March 2, 1767. 
favourable turn for Haidar. The Nairs of Kolattiri, Kottayam, Kadattanad and the Zamorin's country had assembled and were supported by auxiliaries from Travancore and with munitions by the English at Tellicherry. Haidar's troops had been expelled from Kottayam and Kadattanad. In Kolattiri and the country of the Zamorin they still had most of the forts in their possession, but Breekpot thought that they would undoubtedly have to give up these as well unless Haidar sent assistance before the start of the rainy season. Madanna seemed to be in a quandary. He wrote to Breekpot that he was willing to enter into peace-negotiations with the pretender to the Zamorin's dominions and asked Breekpot to assist in this project. When he wrote about all this to Falck, Breekpot had not yet replied to this proposal as he thought it better to await further developments, the more so as the pretender had an agreement with Rama-Varma who intended to reinstate all rulers who had been expelled by force of weapons, on conditions favourable to him, so that eventually he would control the whole of Malabar. ${ }^{154}$

I am afraid I completely fail to see the logic of this last argument. As things stood it was on the one hand doubtful whether the Mysorean troops would receive assistance, and on the other hand there existed this clear threat of Travancore domination. One would have expected Breekpot to jump at this chance of mediating. Moreover, since the proposal had been made by Haidar's lieutenant there was no real danger of a rebuff from that side later on, even if the relief should have come in time. And it was certainly not in the interest of the Dutch that Travancore should find an opportunity to realize its designs. So, if ever, here was an occasion in which everything was to be said for playing the part of an intermediary, a part the thought of which, according to Breekpot's own words, had been the background of his proposals regarding the Dutch policy in Malabar a year ago.155 In my opinion, the explanation of his inconsistent and hesitating behaviour should partly be sought in Batavia's reaction to his ideas when it laid such a strong stress on maintaining a strict neutrality. But next to this I suspect that it is a matter of a good deal of obstinacy on Breekpot's side. His attitude during this period creates the impression that he felt irritated about the way Batavia had reacted, and above all, was hurt by the fact that in certain matters he had been placed under Falck's

164 L.f. C., 1768, II, Breekpot to Falck, s.l., March 28, 1767.

155 L.f.M., 1768, I, Breekpot to Batavia, s.l., April 6, 1767. 
supervision. Hence his attitude of "you have asked for neutrality, now you shall have it".

Meanwhile, Falck's approach to the problem of the relations with Haidar was different. In reply to another letter from Breekpot of 17 February he agreed with him that it was advisable to await $\mathrm{La}$ Beaume's return before taking a definite decision about the treaty of commerce. At the same time he advised Breekpot to conclude contracts for the exchange of muskets for pepper if a suitable opportunity presented itself. For this purpose he should retain for some time the 2,000 flintlocks which had been sent from Ceylon.156

In his reply to this advice Breekpot pointed out that still no relief had been sent to the Zamorin's country so that Haidar's men were pressed harder and harder. There were rumours of peace between Haidar and the Marathas and of Haidar's troops moving to Malabar, but they were unconfirmed. Under these circumstances Breekpot saw no possibility of making contracts with Haidar, who according to him was being well provided with muskets by the British, French and others. It was not to be expected that he would supply pepper for flintlocks at a cheap rate. 157

Here Breekpot is sheltering himself behind excuses, and not very good ones at that, for apart from the raja of Coimbatore Haidar himself had asked for muskets and shot to be delivered at Calicut in a letter handed over by La Beaume.158 No wonder that Falck became annoyed, the more so as Haidar now had approached him with the same request. So he wrote to Breekpot saying that he wished to know exactly what Breekpot had replied to Haidar's request.159

Breekpot replied that he had now received another letter from Haidar requesting munitions. Haidar himself was encircled in Seringapatam and his men were cutt off near Calicut. True, he had written that a peace-treaty with the Marathas had been signed and that they and the Nizam had retreated, but other communications read differently. The latter seemed more probable to Breekpot, for no assistance was being sent to Calicut. He, therefore, did not think it wise to supply Haidar with munitions. The result would be that the Dutch would make themselves hated by Travancore and would receive no more pepper. Never-

\footnotetext{
156 L.f.C., 1768, IV, Falck to Breekpot, s.1., March 15, 1767. See also p. 56 supra.

157 L.f. C., 1768, II, Breekpot to Falck, s.l., May 12, 1767.

158 L. f. M., 1768, I, Haidar to Breekpot, received March 19, 1767.

150 L. f. C., 1768, IV, Falck to Breekpot, s.l., June 11, 1767.
} 
theless, Breekpot would have delivered some flintlocks if the payment took place at Cochin, or if pepper were to be given in exchange at a suitable price. But to deliver at Calicut was too risky. It was wellknown that Madanna had neither cash nor pepper at his disposal. If Falck stuck to his opinion that munitions should be sold to Haidar, to be paid for in money immediately or later, he should give his orders accordingly. Breekpot wrote he would have obeyed the earlier instructions if he had not been of opinion that he should first acquaint Falck with Haidar's state of affairs. 160

This time Falck did not send an immediate reply but preferred first to consult the Governor of Coromandel who had also been mentioned in Batavia's resolution of 21 July 1766 as someone whose advice he should seek in the matter of the commercial treaty. To Haksteen he wrote that, in his opinion, Haidar would probably satisfy the Marathas with a few lakhs of rupees, after which he would be able to defeat Travancore as the latter certainly was weaker than Haidar and the British did not seem to bother about Travancore. Falck feared that once Haidar had attained his object he would be angry with the Dutch because they had not been willing to give him what Travancore received under a treaty which it badly fulfilled, and what, according to Breekpot's own letter, he could obtain from other European nations. Would it not, in order to avoid becoming at variance with Travancore, be advisable to comply covertly with Haidar's request by disposing of muskets and shot to some private person at Colombo? La Beaume was leaving for Coromandel and he would say more about it. Falck, however, warned Haksteen that La Beaume might try to give him an embellished impression of Haidar's state of affairs.161

Haksteen fully agreed to Falck's proposal. When he replied he had not yet met La Beaume who was still at Jaffna. Haksteen pointed out to Falck that Haidar's affairs meanwhile had changed for the better, the Nizam had again taken his side and was marching against Muhammad Ali. It was in the Dutch interests that Haidar should not be subjugated, for he could always be a check on Muhammad Ali and the British. ${ }^{162}$

Thereupon Falck advised Breekpot to send a reliable native to Haidar's army with a letter in general and friendly terms, in which he should intimate his desire to enter into negotiations about Haidar's

100 L.f.C., 1768, IV, Breekpot to Falck, s.l., July 1, 1767.

101 L.f.C., 1768, IV, Falck to Haksteen, s.l., July 11, 1767.

192 L. f. C., 1768, IV, Haksteen to Falck, s.l., Augist 13, 1767. 
requests with one or more of his accredited envoys. Breekpot's messenger, however, should be secretly instructed to tell Haidar in person that the Company was willing to assist him with implements of war, but that the tie of friendship with Muhammad Ali against whom he was now fighting prevented this. It was the messenger's task to suggest to Haidar to commission some native, for instance, Surion, to exchange flintlocks or guns for pepper. This exchange was the best way to keep the Dutch neutral, for other nations were acting in the same manner. If Haidar could be induced to send a vessel with pepper straight to Ceylon he would there receive flintlocks and guns in exchange. 163

But again Breekpot did not take Falck's advice. In his reply a month later he reported that so far as Malabar was concerned things were still in the same state as described by him on 1 July. The Nairs were practically masters of the country-side of Kadattanad, Kottayam, Kolattiri and the Zamorin's country, and Haidar's men were still in possession of the most important forts in these countries. They had not received any assistance from Mysore, although in August about 1,500 men had arrived at Palghat whose task was to protect that kingdom against the designs of its ruler in exile. It seemed that Travancore wanted to await the course of events in the east. Breekpot could not ascertain Haidar's present quarters in order to send a reliable person to him. He had written to Kroonenberg to make inquiries in the north about it. At their urgent requests Breekpot had provided Madanna and Ali Raja with some shot through merchants. He would also have supplied flintlocks but these were so expensive that their envoy did not want to accept them without further orders. 164

It should be noticed that there is a discrepancy in this last letter where it is first stated that the situation had remained unchanged, and then that Haidar's troops still held the main forts. The conclusion must be that these forts had also been in their possession when Breekpot wrote his earlier letters, whereas at that time he gave the impression that Calicut was the only fort still in the hands of the Mysorean troops. This seems to point to the fact that previously Breekpot had been out to paint Haidar's circumstances blacker than they really were so as to have more reason not to deal with him.

Haidar and Raza Ali Khan applied to Falck a second time during 1767 with a request for muskets and shot. Falck now referred them to

163 L. f. C., 1768, IV, Falck to Breekpot, s.l., September 17, 1767.

164 L. f. C., 1768, IV, Breekpot to Falck, s.l., October 15, 1767. 
Breekpot, and restricted himself to sending some presents through La Beaume in return for those they had sent to him.165 Breekpot could at that time still have acted according to Falck's advice of 17 September, but after open war had broken out between Haidar and the British, the Governor of Ceylon held the view that the Company should now keep to a strict neutrality. ${ }^{16}{ }^{6} \mathrm{He}$ wrote to Breekpot in this sense when the latter in June 1768 had asked his and Haksteen's advice how to act in case Haidar's army would return to Malabar and attack Travancore. Incidentally, this question was practically the same as the one Breekpot had put two years before in a letter to Batavia, but then the High Government had refrained from answering it. Haksteen also advised maintaining strict neutrality and refraining from assistance to either party, even if there was a treaty of mutual assistance with Travancore the details of which were unknown to him.167 Finally, the High Government appeared to be of the same opinion that complete neutrality was the best policy when it dealt with a similar request made by Breekpot simultaneously. ${ }^{168}$

During the first part of 1768 Breekpot's task was indeed far from easy. In March there was an attack by the British and the Nairs on the possessions of Ali Raja in which Dutch neutrality was violated.169 A few days later when the English troops had marched off, Ali Raja's men took possession of a hill on Dutch territory. In view of the gravity of the situation Breekpot asked Batavia to send him 200 European soldiers, no officers, for he had plenty of them! 170 Haidar was so much occupied by his war against Muhammad Ali and the British that he ordered Madanna and Ali Raja to come to an arrangement with the expelled rulers. At first the influence of the English at Tellicherry achieved that these negotiations were broken off,171 but in April 1768 Breekpot received news that Madanna on orders from Haidar had resumed talks with the Zamorin and the raja of Kadattanad, whose territories he evacuated after having received a compensation.172

The advance of the British and Muhammad Ali on Mysore meant

16is L.f. C., 1769, I, Falck to Batavia, s.l., May 28, 1768.

${ }_{1643}$ L. f. C., 1769, I, Falck to Breekpot, s.l., July 2, 1768.

167 L.f. Cor., 1769, I, Haksteen to Batavia, s.l., June 30, 1768.

16s Secret resolutions Governor-General and Councillors, 1766-73, November $10,1768$.

109 L. f. M., 1769, I, Breekpot to Batavia, s.l., March 31, 1768.

170 L.f. M., 1769, I, Breekpot to Batavia, s.l., April 4, 1768.

171 L.f. M., 1769, I, Breekpot to Batavia, s.1., March 31, 1768.

17.2 L. . M., 1769, I, Breekpot to Batavia, s.l., April 30, 1768.

V.K.I. 31 
that Haidar had to fall back on his own country, and so the position became less dangerous for the Dutch in Malabar. As Breekpot wrote to Falck, the fact that Haidar's troops had retreated from the coast made it improbable for the time being that he would make fresh requests for munitions because communications had become difficult now. 173

On the Coromandel coast, however, by the end of 1768 things developed less favourably for the Company as a result of Haidar's advance on Muhammad Ali and the British. In December it was generally thought that Haidar was going to attack Tanjore in revenge for the fact that this country had been obliged to assist Muhammad Ali with a few thousand horse. The Council at Negapatam discussed the situation on 27 December and arrived at the conclusion that the Company should remain neutral. If Tanjore, after having been attacked by Haidar, applied for aid to the Dutch under the existing treaty such an application would have to be refused because Negapatam's power was insufficient. The risk of trade barriers because Tanjore would be offended had to be weighed against the danger of being attacked by Haidar if the Company's aid failed to protect Tanjore from defeat. In the beginning of 1769 the immediate danger was averted when Tanjore lent Haidar two lakhs of rupees and sold him victuals. But this did not mean the end of Haksteen's troubles, for now Tanjore feared the displeasure of Muhammad Ali and the English, and in this connection counted on the defensive treaty with the Dutch. Besides, Haidar seemed to be dissatisfied with the Company because it had failed to compliment him as the French had done. The Council considered on 6 March that Haidar could not yet be regarded as ruler of the Carnatic. Moreover, it did not seem to be his purpose to secure the Nawabship, for in that case he would not lay waste the country like he did in order to force his enemies to pay a high price for peace. His aim was thought to be Madura with its capital Trichinopoly. A resolution was passed to order the Dutch at Sadras to send a short complimentary note in case Haidar's army or some detachments might arrive in their neighbourhood. In contrast with the widespread rumours there was, until then, no proof that territories of the neutral powers had been molested.174

Other reports confirmed that Haidar's army had advanced on Madura and the whole country was in commotion when suddenly the

173 L. f. C., 1769, I, Breekpot to Falck, s.l., July 26, 1768.

174 L. f. Cor., 1770, I, Haksteen to Batavia, April 3, 1769. 
news was received that Muhammad Ali and the English had succeeded in making peace with Haidar. It was said that lack of funds had caused discontent among Haidar's troops, and that after one of his commanders, called in a Dutch letter "Mier Masoel Chan", with 8,000 horse had deserted to Muhammad Ali, Haidar had thought peace necessary. 175

Although during the First Anglo-Mysore War the Dutch more than once had to face great difficulties they succeeded in evading all dangers. Their direct damage was confined to reduction of trade. Haidar's troops wandering about in the vicinity of the Dutch factories along the Coromandel coast caused the inhabitants and merchants of those regions to fly from their homes, and during the first four or five months of 1769 the collection of cloth was at a standstill.176 In Malabar the war made it even more difficult than in other years to collect large amounts of pepper. Travancore had to sell more to the British than before, consequent on its ties with them and Muhammad Ali. It did not stand in awe of the Company and Breekpot's policy to keep Travancore in a good temper went so far that he did not press for demolition of some strongholds built on territory which the Dutch claimed as being theirs. ${ }^{177}$

When writing this on 4 March 1769 Breekpot had already handed over the government of the Dutch possessions in Malabar to his successor Senff to whom he left a Memoir dated 28 February 1769.178

Although the First Anglo-Mysore War ended shortly after Senff had taken over, this did not mean that all tension disappeared from the Malabar coast. In September 1769 it was reported to Senff from

175 L.f.C.,1770, I, Falck to Batavia, June 1, 1769; do., De Vos (resident at Tuticorin) to Falck, May 23, 1769. L.f.C., 1770, II, Short account of the important events during 1769 in Madura, Marrua and Travancore, by de Vos to Falck, December 31, 1769. So far I have not been able to find any corroborative evidence from other sources about the desertion of a "Mier Masoel Chan", nor that a desertion was a motive for Haidar to make peace. Earlier cluring the war, however, it had been suggested to the Bombay Presidency that it might be worth trying to induce Mir Faizulla Khan, Haidar's ablest general, to go over to the enemy (comp. G. W. Forrest, ed. of Selections from the Letters, Despatches, and other State Papers preserved in the Bombay Secretariat, Home Series, II (Bombay, 1887), p. 133). Later on, rumours may have spread that this general had gone over.

176 L.f. Cor., 1770, I, Haksteen to The Seventeen, December 20, 1769.

177 L. f.M., 1770, I, Breekpot and Senff to Batavia, s.l., March 4, 1769.

178 Breekpot, who had repeatedly asked for an honourable discharge, left soon after for Batavia where he died within a year. Senff, who had been serving the Company since 1737, lastly as its Director at Surat, was appointed with the new title of Governor of Malabar (comp. van Resandt, op. cit., pp. 195-6). 
Cannanore that the British were making preparations for war against Ali Raja, and the Cochin Council therefore thought it necessary to warn the English at Tellicherry that the fort and town of Cannanore belonged to the Dutch, and that the special quarter or so-called bazaar where Ali Raja and the prominent merchants resided was part of the town. This gesture made a great impression on Ali Raja who, as Senff wrote, was a person of weight by his alliance with Haidar, and whose friendship might be useful to the Company. In the same letter Senff gave his opinion on the matter of the demolition of the strongholds at Chetvai, Quilon and Cranganore. In a letter of 26 September 1768 Batavia had given orders to demolish, without further arguing, first those at Chetvai and Quilon and then that at Cranganore. The new Governor wrote that a middle course between creating no small stir and gross disobedience was being adopted by removing the servants and equipment from the forts and leaving only a Dutch resident with a few Indian servants. By this method it would be easily possible to re-establish the strongholds in their former condition. Meanwhile, Breekpot could give his view at Batavia. 179

Actually, Breekpot had done so already on 11 July 1769 when he presented his further 180 considerations to the High Government. The object of these considerations was to state the reasons why the demolition of the strongholds had not taken place as promptly as Batavia had wished. In this document the late Commander returned to the subject of an alliance with Haidar Ali, and wrote that the three abovementioned strongholds would be of use when a treaty of peace and friendship with Haidar was concluded. In Breekpot's opinion the moment had arrived to carry out Batavia's resolution of $21 \mathrm{July} 1766$ to conclude a contract with him. It was not wise to remain neutral any longer, for there had never been a better chance of gaining future influence and prosperity in Malabar than at present through Haidar, and an advantageous contract was improbable after Haidar had succeeded in all his plans. An agreement with Haidar having been reached, Breekpot's idea was to induce him to compel Travancore to cede to the Company all its beaches or islands in between the sea and the rivers from Chetvai to Quilon. The Dutch should prevail upon Cochin's raja to give up his territory in the same region in compensation of which he would get districts at present partly belonging to Travancore.

179 L. f. M., 1770, I, Senff to The Seventeen, October 20, 1769.

180 This document is to be regarded as a supplement to his Memoir. 
Breekpot suggested making an offer of Cannanore to Haidar as a reward if he obliged in other matters. ${ }^{181}$ In his Memoir he had stated that owing to Haidar's unsettled circumstances he had not dared to approach him on the subject of a possible sale of the fort.182

After the High Government had taken notice of Breekpot's considerations a resolution was passed to send instructions to Senff to carry out the order of 31 October 1766 to offer Cannanore for sale to Haidar unless the present circumstances did not permit of such a step. 183

When Senff received this instruction Haidar was at war against the Marathas and Cochin's Governor tried to approach him through Ali Raja. But when the latter heard about the offer he asked whether he himself could buy Cannanore. Senff liked this idea because he thought that Haidar would not consider this place to be an important acquisition. This in contradistinction to Ali Raja who had just obtained full possession of Kolattiri and was a bitter enemy of the English. According to Senff it did not make much difference to the Company who was the eventual buyer. 184

In a letter of 26 September 1769 Batavia had asked Senff to comment upon Breekpot's further considerations regarding a contract with Haidar. As the Governor-General van der Parra had done in 1766, Senff's treatise started with a tirade on the transitoriness of the power of a prince who was not by nature born to rule. He admitted that an alliance as Breekpot had proposed might bring prosperity, prestige and power beyond description to the Company, but the proposal itself was so mysterious in many ways and the means to carry it out were so full of uncertainties and difficulties, that he did not think it could ever be realized along those lines. His practical objections amounted to: 1. Since he had made peace with the British it was not likely that Haidar was going to attack Travancore, a British ally. 2. Was Haidar still so keen on a treaty with the Dutch? 3 . He would certainly not

181 Hooge Regeering Batavia 739, Further considerations of the former Commander of Malabar Cornelis Breekpot presented to the Governor-General and Councillors at Batavia on July 11, 1769.

182 Mem. Breekpot, p. 5.

183 Hooge Regecring Batavia 754, Extract from the resolution of the High Government, July 27, 1769.

1.8. L. f. M., 1771, I, Treatise about different matters concerning the state of the Company's interests on the Malabar coast by the titular Governor Senff, April 15, 1770 - hereinafter cited as Treatise Senff; do., Senff to Batavia, s.l., March 15, 1770. 
accept an agreement which contained only advantages to the Company and disadvantages to himself, even if Cannanore was to be given to him beforehand. 4. The Company had no right whatever to the territories mentioned. 5. The Company would get no profit out of possessions destroyed by war. 6 . If Haidar kept Travancore for himself he would be a far more dangerous neighbour than Travancore was now. On the other hand, if he returned the country to its raja, Travancore would be longing for revenge on the Dutch. Senff's conclusion therefore was that he disapproved of an offensive or a defensive alliance but agreed to a treaty which merely had as its object the maintenance of peace and friendship. Such a treaty should be pursued without delay. The Company should be prepared to sell munitions for cash if Haidar committed himself to live in peace with the Dutch and their allies. 185

Meanwhile, it had seemed for a short time as if matters between the Company and Travancore would come to a head when in November 1769 the Cochin Council sent some troops to Cranganore where they had a skirmish in defence-works constructed by Travancore. But things were settled amicably after Rama-Varma sent an envoy to Senff. At the same time a number of other issues were discussed, and Senff in his report on the dealings made much of the result of the talks, although he had to admit that the demolition of the Travancore defence-works was still left unsettled. ${ }^{186}$

Very shortly afterwards Senff had to report that Travancore was still far from fulfilling his high expectations. At his request a special ship had been sent from Ceylon to collect the 4,000 candies of pepper he expected to receive, but when the ship arrived Senff found that he had no pepper for it. $187 \mathrm{He}$ had more success, however, when he decided to withdraw the pepper-passports. According to contract Travancore's raja was entitled to a passport for 100 candies of pepper which he was allowed to sell where and to whom he wished, after every 300 candies he had supplied to the Company, this to a maximum of 10 passports. The practice had been, however, that the 10 passports were always given, independently of the fact whether Travancore had supplied the full amount of pepper or not.188 The result of Senff's measure now proved to be better than most people had anticipated and

185 L.f.M., 1771, I, Treatise Senff.

186 L. f.M., 1771, I, Short notes of the Governor about the happenings and discussions with Travancore between 13 November 1769 and 25 February 1770, February 25, 1770.

187 L. f. M., 1771, I, Senff to Batavia, April 25, 1770.

188 Mem. Breekpot, p. 33. 
the raja was angry with his own pepper-servants. ${ }^{189}$ Consequently, it did not seem necessary for the time being to proceed to a further action Senff had been contemplating, namely, to prevent Travancore from buying tobacco at Jaffna. Tobacco was one of the main sources of income for the raja by the heavy duties put on its sale and consumption. In Senff's opinion it might be better for the Company to buy up all tobacco and destroy part of it than to give up, under compulsion, the legal profit of the pepper collection. Rightly he observed that the undue leniency which seemed to have been an important principle of the Malabar policy for many years had made Travancore so bold. 190

Keeping in mind a remark by Senff that he could not contact Haidar on the issue of Cannanore's sale owing to his war against the Marathas, 191 there is no reason to expect them to have exchanged any correspondence. In fact, however, there was some contact during these years. In July 1769 Senff sent a complimentary letter through the raja of Coimbatore when the latter left Cochin where he had been staying for some time after having been expelled by the British.192 In March 1770 someone sent by the Paljetter returned from Haidar's army with a letter for Senff, in which it was stated that the person sent, called "Senff's envoy", had given an account of the state of affairs, and that on hearing his account he, Haidar, had firmly determined upon living in friendship with the Company. He had always been on good terms with Senff's predecessors. 193 Replying to this letter in July Senff remarked that he was firmly convinced that his first letter had never been delivered to Haidar and he requested him to give an assurance of his intention to live in sincere friendship with the Company's servants. 194 To this Haidar replied in October 1770 that Senff's first letter had not got lost but at the time of receipt he had been too busy to answer it. He further announced that before long he would again proceed with his army to Malabar.195

189 L.f.M., 1771, I, Senff to Batavia, May 15, 1770.

190 L.f.M., 1771, I, Treatise Senff.

101 L.f. M., 1771, I, Senff to Batavia, s.l., March 15, 1770.

102 L. f. M., 1770, I, Proceedings of the Cochin Council, July 15, 1769.

193 L. f. M., 1771, II, Haidar to Senff, received March 28, 1770.

194 L. f. M., 1771, II, Senff to Haidar, July 2, 1770.

195 L. f. M., 1772, III, Haidar to Senff, October 13, 1770. This letter was only delivercd to Senff on 14 December after he had exchanged letters with the raja of Cochin and the Paljetter whom he accused of holding back Haidar's letter and present which had been carried by one of their messengers (L.f.M., 1772, III, Senff to the raja of Cochin, December 3,1770; do., The 
The contents of this correspondence may not be very exciting, but the fact of its existence indicates that if Senff had really wished to approach Haidar about Cannanore he could have found an opportunity to do so, whether Haidar was at war or not. It is rather difficult to understand why Senff preferred to sell Cannanore to Ali Raja, whose record in the Company's documents was far from good, instead of to Haidar as his instructions read, unless one assumes that this transaction would bring some financial profit to Senff personally. Of course, this cannot be proved but it seems to provide the only reasonable explanation of Senff's conduct in this matter. ${ }^{196}$ Anyhow, he got the opportunity to carry out his proposal, for he was commissioned by a letter of 3 August 1770 from Batavia to sell Cannanore to Ali Raja for 100,000 rupees or somewhat less. 197 The sale took place for the full amount but only 60,366 rupees were paid for in cash; bonds were given for the rest. On 3 March 1771 the fort changed hands. 198

Soon afterwards Senff left Malabar for Batavia where he died during the same year. His successor Moens arrived at Cochin from Ceylon where he had served the Company in several posts. 199

In the meantime the prelude to events which could be expected when Haidar would indeed appear with his army, had started when the Zamorin complained about an attack by troops of the raja of Cochin together with troops of Haidar's commander at Palghat.200 Senff

raja of Cochin to Senff, December 3, 1770; do.. Senff to the Paljetter, December 13, 1770; do., The raja of Cochin to Senff, December 14, 1770).

196 In this respect it is interesting to take note of the fact that on his way from Surat to Cochin where he was to take up his new post, Senff had a meeting with Ali Raja at Cannanore during which discussions on commercial matters took place ("Memoir written in the year 1781 A. D. by Adriaan Moens, Extraordinary member of the Batavia Council, Governor and Director of the Malabar Coast, Canara and Vingurla, for his successor", Sel. Dutch Records Madras No. 2 (Madras, 1908) - hereinafter cited as Mem. Mocns -, p. 51).

197 Hooge Regcering Batavia 754, Batavia to Senff, s.l., August 3, 1770.

193 L.f.M., 1772, II, Senff and Moens to Batavia, March 30, 1771. A letter from Tellicherry of 3 March 1771 states that Ali Raja lately had purchased the fort and districts of Cannanore for two lakhs of rupees (Bombay Abstract Letters Received, 3, 1767-83, Tellicherry to Court of Directors, March 3. 1771). The amount of two lakhs mentioned here instead of the one lakh in the Dutch correspondence may also point to the fact that the whole transaction brought considerable profit to Senff. A similar impression is sained from a Dutch pamphlet of 1780 on the state of affairs of the Company which imputed disloyalty to Senff in connection with this transaction (see $\mathrm{Ncdcr}$ landsch India, in haaren tegenzeocrdigen tocstand beschouzed (Batavia, 1780), p. 62).

199 See van Resandt, op. cit., pp. 196-7.

200 L. f.M., 1772, III, The Zamorin to Senff, received February 18, 1771. 
protested with the raja and the Paljetter against their imprudence in bringing foreign troops into the country. 201 The matter came up for discussion at a meeting of the High Government on 19 September 1771 and a resolution was passed that Mocns should be instructed to further impress on Cochin's raja the rashness of his behaviour and to dissuade him emphatically from bringing in foreign troops. At the same time it was decided that as so far there had been no opportunity to open negotiations with Haidar because of his war against the Marathas - this had been communicated in Cochin's letter of 30 March 1771 - Moens should be ordered to act in that sense as soon as he deemed circumstances favourable.202

Apparently Moens and his Council did not consider this condition fulfilled, for there is no indication that they entered into any negotiations with Haidar. This is not so surprising if we take into account that Mocns knew nothing about the developments in Malabar when he arrived at Cochin, and contrary to most of his predecessors it may have taken him some time to obtain the necessary knowledge and insight, for Senff had not left him a Memoir. Moens therefore had to go into the documents themselves 203 and the result was that ultimately he knew probably far more about Malabar than any of his predecessors or successors. Consequently, I think that regarding this point of negotiations with Haidar, Moens at this time went entirely by Senff's opinion, known to him from their joint letter to Batavia, namely, that owing to war contact with Haidar was practically impossible. Besides, during the first period of Moens's administration there were serious quarrels with the raja of Cochin, and in view of the complicated relations - Travancore had to be kept out as much as possible these must have taken a great deal of his time and attention.

In 1773, however, it became clear that Moens would have to pay attention to Haidar in future, for during April of that year the latter invaded Coorg 204 with an army of 20,000. Although its ruler made a gallant stand he could not prevent Haidar from conquering most of the country. It is true that at the start of the rainy season Haidar withdrew with most of his troops to Mysore, but he left some of them in the occupied strongholds. The Zamorin frightened by this invasion

201 L. f. M., 1772, II, Senff and Mocns to Batavia, March 30, 1771.

202 Secret resolutions Gozernor-General and Councillors, 1766--73, September 19, 1771.

2013 Mem. Moens, p. 1.

${ }^{204}$ Called in the Dutch letters Coddagamala, Coddemaloer or Corque. 
applied to Moens for intercession with Haidar in case he would proceed with his advance. When it became known that Haidar had left Coorg with the main part of his troops the Zamorin thought that the danger was over and so he no longer pressed the matter of bringing about a settlement between him and Haidar.205 But before the end of the year the Zamorin's day-dream that matters would not come to a head was rudely disturbed when in November reports were received that Haidar was making all sorts of preparations for another campaign in Malabar. After an uncertain period of rumours it soon became evident that this time the advance was aimed at the Zamorin who was considerably in arrears with his tribute. In the beginning of December the attack was started after the arrival of Haidar's commander Srinivasa Rao at Palghat.

Soon afterwards the Zamorin asked Moens for a right of way through the Company's territory to Paravur for the benefit of his relatives who had fled southwards when they heard of the army's arrival at Palghat. However, before the reply was passed on to the Zamorin these relatives left for the north because it became clear that Travancore and Cochin were not going to admit them for fear of difficulties with Haidar. The Zamorin seemed to have somewhat more success when he applied for aid to the French at Mahé. The French commander Duprat, who had only recently arrived, opened negotiations and concluded a treaty on 12 January 1774 by which the whole country of the Zamorin came under French protection. Duprat took a detachment of 140 men in a ship to Calicut where he was very courteously welcomed by the Zamorin. However, the only thing Duprat did to check the enemy consisted of informing Srinivasa Rao, who meanwhile had already left Ponnani behind him, that he had assumed patronage of Calicut in the name of the king of France. But Srinivasa Rao continued his advance and thereupon Duprat had a meeting with him at Beypore during which he tried to persuade him first to ask for Haidar's opinion on the matter and pending this to stop his operations. It was all in vain, Duprat returned to Calicut and retreated into the fort with his detachment and 2,000 Nairs. When the enemy threatened to attack, he abandoned the fort on 19 January and returned to Mahé by the same ship that had brought him. Shortly before the Zamorin had fled

205 L.f.M., 1774, Moens to The Seventeen, October 15, 1773; do., The Zamorin to Moens, received April 22, 1773. "Historical Account of Nawab Hyder Ali Khan", Scl. Dutch Records Madras No. 5 (Madras, 1908) - hereinafter cited as Hist. Acc. -, p. 18. 
into the mountains, whereupon the whole country was easily conquered. In his description of these events Moens remarked that their queer and rash nature made many people wonder whether the French action had been carried out with the prescience of Haidar so as to facilitate the conquest of the country. But his own opinion was that Duprat had only been out to enrich himself. The result was that Haidar undoubtedly would distrust the French more than ever before, although he dissembled his dissatisfaction and pretended to regard the episode as a rash step by someone who had only recently arrived from Europe. 206 Moens observed further that so far no suitable opportunity had presented itself to find out Haidar's present disposition towards the Company as for several years now, in fact even during the attack on Calicut, he had been staying far from home in his northern territories or, rather, in Mysore. ${ }^{207} \mathrm{He}$ supposed, however, that Haidar felt that the Dutch had not taken great pains over his protestations of friendship at the time of his stay at Calicut. It was necessary to await an opportunity to gather up the threads, for it was not wise to show too much eagerness as this might make him all the more unmanageable if he expanded his territory further southwards. In the present state of affairs Moens thought that the Dutch could not expect much of him. He did not even consider Haidar to be of much use to the French, at least not in the same way as Muhammad Ali was to the British, for Haidar was far too cunning to become a puppet. 208

At the approach of the Mysorean army the raja of Cochin had feared an invasion of his northern territories near those of the Zamorin. Therefore he had sent envoys to buy Haidar's friendship for two lakhs of rupees, whereas a small party of Mysoreans had been encamped at Trichur and a few hundred Nairs had been sent to campaign with the Mysorean army. Cochin's raja tried to collect his tribute by levying special taxes on his subjects' estates. Part of it was lent by RamaVarma who had strongly recommended the deal in order to keep Haidar north of Cochin. Moens admitted that probably the raja's fear had not been unfounded, but he objected to the fact that the raja had not consulted him beforehand in concluding an agreement of such far-reaching consequences. He did not think it wise, however, to denounce the transaction as this might give offence to Haidar, and

206 L. f. M., 1775, I, Moens to Batavia, March 28, 1774. Hist. Acc., pp. 19-20.

207 This is a further example of the fact that Haidar was not nearly always considered ruler of Mysore in the first place. Comp. p. 54 supra.

208 L. f. M., 1775, I, Moens to Batavia, March 28, 1774. 
he therefore disguised his displeasure, but he was determined to protest with the raja at some future occasion.

The raja of Cranganore proceeded with more caution, according to Moens, when on 1 March 1774 he was instructed by a certain Haidros Kutti, a Muslim with some following in the country of the Zamorin where he now behaved as an administrator of a few districts, to pay Haidar tribute of 100,000 rupees and two elephants. The raja informed the Dutch resident at Cranganore who was subsequently instructed by Moens to tell him that he should refrain from any negotiations, replying to Haidros Kutti that he was under the special protection of the Company and therefore could do nothing without its knowledge. Haidros Kutti alleged that earlier the raja of Cranganore had promised tribute to Haidar, but this the raja denied to the resident. Mocns supposed that Haidros Kutti had acted without special orders from Haidar, because like other new district-collectors he had promised Haidar larger amounts of money than he could actually collect.209

Meanwhile, the ruler of Kottayam invaded Coorg with the initial success of routing the Mysorean troops. But Haidar sent reinforcements from Mysore and came personally with troops from Seringapatam. Assisted by Ali Raja's men and Nairs of the chief of Kadattanad, who met their obligations of tribute to Haidar, he reconquered Coorg and subsequently attacked Kottayam from the north side, whereas Srinivasa Rao marched on it from Calicut. The rulers of Coorg and Kottayam and the Zamorin sought safety in flight and left Kottayam to Haidar. The Zamorin wanted to go to Travancore and asked Mocns for free passage. No reply was sent to this request received at Cochin on 5 April, but the resident of Chetvai told the Zamorin's messengers that their master would not be allowed to pass through the territory of the raja of Cranganore. A month later, however, it was learnt that the Zamorin with his relatives and 2,000 Nairs had fought his way through the enemy and had taken up residence in an unoccupied palace of Cranganore's raja. Several representations to leave the region were made to the Zamorin, and when it appeared that the rajas of Cochin and Travancore were also unwilling to admit him into their territories he left again for the north on the 11 th of May, whereas his female relatives secretly obtained passage to the south. Two days later the Zamorin found two vessels near Paponetty to transport him with the princes and some 100 Nairs oversea to Travancore where he landed

209 L. f. M., 1775, I, Moens to Batavia, March 28, 1774. Hist. Acc. p1. 19-20. 
at Cherttala and was arrested after the guards of Travancore had prevented the vessels twice from going ashore. 210

While these events were taking place the raja of Cranganore also required Moens's attention on account of another matter. On 7 April 1774 Moens learnt from a letter of the raja that on the 29th of March he had received letters from Haidros Kutti and Chandra Rao, the commander of Haidar's troops at Chowghat, and according to Moens a brother of Srinivasa Rao,211 demanding from him a tribute of 100,000 rupees and one elephant. The raja pointed out in his letter that a similar demand had been made in 1766 and that at that time the Dutch Commander had written a letter in which he overrode the claim. He requested Moens to do the same now. But before Moens had taken any action Chandra Rao sent an armed escort with a second letter to the raja on 10 April. In this letter, which was forwarded by the raja to Moens, Chandra Rao argued that at the time when Haidar had been in this region the raja had undertaken to provide him with a lakh of rupees and an elephant. The raja was therefore now invited to come to Chowghat in order to settle the affair. Moens thereupon instructed his resident at Cranganore to reply to Chandra Rao that the raja of Cranganore had been under the special protection of the Company since 1717 , that the Company would not object to tribute being levied on property situated in the Zamorin's dominions, but that it was considered improper that he had sent armed men through Company's territory to the raja's court. As this action was contrary to the respect and friendship existing between the Company and his master, it was expected that he would take measures to prevent a repetition. To this letter of 17 April a reply was received ten days later in which Chandra Rao wrote that he had no power to exempt the raja from the tribute. He suggested that Moens should write about it to Haidar and state the reasons of the Company's protection of Cranganore. As his soldiers had not practised any hostilities in Dutch territory, he did not understand why objections had been raised against their passage through Dutch districts, for, as the Governor himself had written, the Company and Haidar were living in good friendship.

Mocns took advantage of this opportunity to get into touch with

$\because 10$ Hist. Acc., pp. 20-3. L. f. M., 1775, II, Moens to Batavia s.l., June 18, 1774.

211 Like Srinivasa Rao is called in the Dutch records Sriniwasa Raijer, Chandra Rao's name is given as Chandra Raijer or Sandra Raijer of Chiander Raijer or Sander Raijer. That the two were brothers is stated also by Rao, who, however, does not mention Chandra Rao as an officer taking part in this campaign (see Rao, op cit., II, p. 228, note 3). 
Haidar and wrote him a letter in the beginning of May in which he explained the situation and requested that Cranganore be left in peace in accordance with the promise of 1766 . This letter was dispatched to Chetvai with an order to the resident there to have it carried by a reliable messenger to Haidar who was expected to arrive at Calicut from Kottayam. But between Ponnani and Calicut the messenger met Chandra Rao who informed him that Haidar had left Kottayam for Seringapatam. Chandra Rao promised to dispatch the letter to Haidar and gave a receipt for it. Later on it was learnt at Cochin that Haidar had left suddenly for Seringapatam because four powder-magazines had exploded. Thousands of people were said to have been killed and the town was heavily damaged.212

On 12 May, one day after the Zamorin had left Cranganore territory, Moens received another letter from Chandra Rao in which he was requested to hand over the Zamorin and his relatives as well as their treasures. In case Moens faileà to do so Chandra Rao threatened to proceed with his army from Chowghat to fetch them. Moens replied the next day that the imputation that the Company had granted Haidar's enemy a stay at Cranganore was baseless. If it could be proved that treasures had been hidden at Cranganore the Company was willing to give assistance in tracing them, as had been offered in a similar case in 1766.

Several other letters were exchanged and in them Chandra Rao returned to the subject of the tribute which he was demanding in Haidar's name from the raja of Cranganore, and which he now increased to one lakh of rupees and four elephants. This would force him to send some troops to Cranganore. By now Moens was convinced that the raja had indeed promised Haidar tribute in $1766.213 \mathrm{He}$ believed that the reason for this promise had been the fact that at that time the raja of Cranganore had to redeem the reception at his court of the late Zamorin's relatives and the collecting of troops by

212 L. f. M., 1775, III, The raja of Cranganore to Moens, received April 7, 1774; do., Chandra Rao to the raja of Cranganore, received (by Moens) April 11, 1774. L. f.M., 1775, II, Moens to Batavia, s.l., June 18, 1774. Hist. Acc., pp. 21-2. Rao relates that in May 1774 the old magazine at Seringapatam caught fire, involving considerable loss of life and property, but he does not connect Haidar's movements with this event (comp. Rao, op. cit., III, pp. 288-9).

213 Hist. Acc., p. 27, gives 1767 and p. 30 mentions 1768 as the year in which the promise was made, but this seems to be wrong, as follows from Moens's secret letter to Batavia of 18 June 1774 which has 1766. 
the princes of Calicut on his territory. On 18 May Chandra Rao sent a few hundred men through the Company's districts to Cranganore. When the raja wanted to leave for Cochin the Dutch resident at Cranganore advised him to stay in his residence and open negotiations with the Mysoreans. It was pointed out to him that it was his own fault that they first had made a demand on him, and now insisted on its fulfilment. For, as the resident at Cranganore reported to Moens, armed Nairs had been hiding on Cranganore territory till the Mysoreans advanced upon it. Meanwhile, the raja of Cochin and the Paljetter offered the raja of Cranganore their mediation and so Moens made them understand that the Company on the one hand could not permit its vassal to pay tribute, but that on the other hand no objection would be made against a present by the raja in compensation for what he had promised Haidar. Thus the raja would be able to provide the money without the Company's public consent and the Dutch claim on his kingdom could be saved. The raja thereupon first went to see the Paljetter and, later on, Chandra Rao with whom after some days a settlement was reached, the raja undertaking to pay 50,000 rupees in two instalments and three elephants. Meanwhile, the Mysoreans were hunting for the treasures of the Zamorin on Cranganore's and on the Company's territories. They had some disputes with the Dutch overseer whom Moens had sent along together with 30 soldiers, over muskets and brass-ware which they claimed to have belonged to the Zamorin, but when the Dutch assumed an uncompromising attitude they became more docile. After the unsuccessful investigation the Company received a friendly letter of thanks. ${ }^{214}$

When Moens wrote about these events he had still not received any reply from Haidar and he had therefore given a copy of his letter along with Surion who had departed for Calicut on business. Moens also wrote a letter to Srinivasa Rao, who, meanwhile, had become Haidar's governor at Calicut, and Surion was instructed to hint during an oral explanation that Moens would have been very pleased if he could have met Haidar at Calicut, thus giving the impression that Moens was after something special. Moens found it extremely difficult to learn more about Haidar's future plans because his designs were kept from his commanders till the very time of execution and nobody dared to discuss matters of war. The general feeling, however, was that Travancore would be attacked at the beginning of the fair weather. In

214 Hist. Acc., pp. 23-8. L. f. M., 1775, II, Moens to Batavia, s.l., June 18, 1774. 
that case the Company's position would be rather difficult, but Moens intended to act in accordance with the directives to remain neutral, meanwhile watching the Company's interests. If, unfortunately, the worst came to the worst he would choose the lesser of two evils. At the same time he would try to maintain the Company's reputation and would not strive for changes in important matters unless he could be sure of their success. 215

In June Surion reported from Calicut that he had met Srinivasa Rao who told him that he would do his best to preserve the friendship between Haidar and the Company. At the same time Haidar's commander also mentioned that his master was angry with Surion because he had failed in his mission of 1766 to the rajas of Travancore and Cochin who were to have made contributions so as to be left in peace. When Srinivasa Rao then asked whether the Company would be willing to supply him with munitions if he requested them, Surion assured him that the Company would not fail to do so. In the same month Moens received two letters from Srinivasa $\mathrm{Rao}$, in the first of which he acknowledged receipt of the copy of the letter to Haidar which he would forward. In connection with Moens's complaint about the appearance of his brother's troops on Dutch territory, Srinivasa Rao stated that it was all the result of the conduct of the raja of Cranganore who deserved that his whole country had been overrun. It was only due to Moens's request that he had ordered Chandra Rao to settle the dispute for a small amount of money. In the second letter Moens was asked not to prevent Surion from sending muskets from Cochin to Calicut. 216

Moens's scheme to rouse Haidar's curiosity as to his intentions through Surion's talk with Srinivasa Rao, thus effecting that Haidar would run after him, did not seem to work, for Moens not only got no reply to his letter or its copy, but also received information pointing to the fact that Haidar's coolness towards the Company was gradually increasing. It was said that at his court there was much talk of the Company and that Haidar had given as his opinion that his affairs in Malabar were no concern of the Dutch who should not stand in his way. Haidar even seemed to insinuate that the treasures of the Zamorin might quite well be concealed in the Dutch forts of Chetvai and Cranganore. By now Moens knew that Haidar was dissatisfied with the Dutch

215 L. f. M., 1775, II, Moens to Batavia, s.l., June 18, 1774.

216 Hist. Acc., pp. 30-1. 
because they had not availed themselves of his offer of 1766 . But the Governor of Cochin sensed that this was not the only reason for Haidar's coolness and finally he found out another cause for dissatisfaction, namely, that Haidar had never received any presents in return for those sent by him to the Governor-General in 1766 ! On hearing this, Moens at first thought that Haidar, being very greedy and keen on presents, had received some which he did not consider sufficient, but when he went into the matter more carefully he soon found that after the notice of 6 April 1767217 that the presents were going to be sent to Ponnani at the first opportunity, not a single line concerning them could be traced in the Company's records. He also made inquiries with several Company's servants but nobody seemed to know anything about presents for Haidar which had not been forwarded. Finally, Moens discovered part of the commodities meant to be presented to Haidar in 1767, in the armoury and in the warehouse. But nobody knew that they represented gifts, let alone gifts meant for Haidar! The missing items had gradually been used for presents to other rulers. From the correspondence conducted at the time with Madanna Haidar knew quite well that the presents had arrived at Cochin. The letter which had originally accompanied the presents could not be traced, nor could anybody give Moens information about it. He therefore supposed that it might have been forwarded to Haidar some time after 6 April 1767. He further assumed that, when at the time the Dutch at Cochin noticed that the Marathas gave Haidar no end of trouble, they might have postponed the forwarding of the articles to await the outcome of events, at the same time forgetting to keep a record of it. But there it was, and the problem now arose how to redress matters in such a way that the appearance of neglect was obviated so that it would look as if only now a suitable opportunity presented itself to forward the presents .

Moens thought that he had succeeded in finding a good solution of the problem in a phrase in his letter to Haidar in which he had suggested a meeting with him at Calicut. This suggestion might now be interpreted as having resulted from the unsettled matter of the presents. Moreover, it came to Moens's ears that Surion was looking for an opportunity to have personal contact with Haidar so as to enlist Haidar's favour even more in his interests at Calicut. Moens therefore had a considerable gift hurriedly prepared after first having inquired

217 See p. 60 supra.

V.K.I. 31 
unobtrusively after Haidar's taste. He found out that the Nawab was not keen on goblets and lamp-chimneys, 218 of which there had been 24 and 300 respectively in the original consignment, but that he was fond of superfine and uncommon woven precious materials. Some remnants of the original gift were added and the whole representing a value of 2,549 guilders was committed to the charge of de Riberto, the resident at Chetvai, who was instructed to deliver it to Surion at Calicut. Letters addressed to Haidar, Srinivasa Rao and Surion were also given along with de Riberto who was ordered to offer the gift to Srinivasa Rao for forwarding to Haidar in case Surion's journey would not take place. This order was put into action when Surion declared that on account of sudden illness he could not set out on the tiring journey to Seringapatam. In view of the bad weather Srinivasa Rao, however, dared not dispatch the goods and only forwarded the letter. Haidar's reply to Moens via Srinivasa Rao contained the request to send de Riberto to Seringapatam in the company of Surion. Moens would have preferred the presents to be forwarded immediately, nevertheless he was satisfied with the result of his ruse, for not only had he removed the cause of Haidar's coolness but he had also achieved that the Mysorean was the first to suggest discussions. The Dutch Governor replied to Calicut that on account of the rainy season the embassy had to be postponed for a while. In his report about these happenings to Batavia Moens expressed his expectation that when the negotiations started Haidar would probably wish to conclude an alliance with the Company. The difficulty would then arise that he, Moens, was not allowed to go beyond what Batavia had laid down as directives in a letter to Cochin of 25 December 1770 after consulting Senff's treatise of 15 April 1770, namely, that during the negotiations with Haidar it should be stipulated that he should assist the Company and its allies and should not offend them. On the other hand the Company would do its utmost in order to supply him with military stores for money, either in cash or on payment shortly after delivery, provided that the amount was not too large. At the same time reciprocal free trade should be stipulated.219

In view of the narrow basis for discussions which Batavia allowed him, one can imagine that Moens was not very happy with the mission to Seringapatam. It is, therefore, not surprising that when the dry

218 Of these Moens remarked that if Haidar had cared a great deal about mosques, he might have been expected to appreciate them.

219 L.f.M., 1775, II, Moens to Batavia, s.l., October 10, 1774. 
season had started he took his time in preparing the embassy, and continued his correspondence with Srinivasa Rao of whom he inquired about the condition of the roads and where Haidar was. ${ }^{220}$ As the Governor of Calicut probably first had to consult Haidar before he could reply to Moens's questions, it took rather a long time before the answer reached Moens. In the beginning of 1775 , however, a letter of Srinivasa Rao was received in which it was stated that Haidar was eager to meet the Company's envoys at Seringapatam. The commissioners could, if they wished, receive an escort, but this seemed superfluous as a good road under construction straight from Seringapatam through the woods and mountains was almost finished. Moens appointed as envoys Saffin, who took part in the mission to Calicut in 1766 , and de Riberto, who delivered the presents at Calicut in 1774.221

It is now time to look into some of the events described above in more detail. From a more general point of view it is interesting to note that Dutch sources point to a character and chronological sequence of events with regard to the conquests of Coorg and Calicut which differ in several respects from the current views. For an elaboration of this point I may refer to Appendix II. As a matter more immediately related to the subject of this study I should like to compare the circumstances under which the Company started its new negotiations with those of nine years before. In 1766 the Dutch could still consider Haidar a ruler who only occasionally would give some trouble, but by 1775 he had emerged as one who was continually aiming at the supremacy over the whole of South India and therefore meant a real danger to his neighbours. In the meantime he had managed to consolidate his power in spite of strong opposition, and especially the result of the war against the British had greatly increased his prestige. On the other hand, it certainly cannot be maintained that the general prospects of the Dutch and their reputation had improved since 1766, on the contrary. The kingdom of Travancore had long been a troublesome partner, but to make matters worse the British were now increasing their influence in that country partly as a result of their war with Haidar. Another indication of the declining prestige of the Dutch is that this time the raja of Cochin did not show any hesitation, as in

220 L. f. M., 1775, II, Moens to Batavia, s.1., January 1, 1775.

221 L.f. M., 1775, II, Moens to Batavia, s.l., January 1, 1775. L.f. M., 1776, I, Moens to Batavia, s.l., February 10, 1775; do., Moens to Batavia, s.l., May 12, 1775. 
1766, to pay Haidar tribute when he invaded Malabar.222 I think therefore that there is every reason to conclude that in 1775 the difference in power and prestige between Haidar and the Dutch was proportionally far greater than nine years before.

Whereas the mission of 1766 in the first place emanated from the idea that the Dutch like other nations had to compliment Haidar on his arrival as a conqueror in Malabar, the reason for sending the embassy in 1775 must be sought entirely in the fact that relations had deteriorated to such an extent that a continuation of this state of affairs could no longer be justified. We have seen that the policy prescribed from Batavia was primarily responsible for this deterioration of relations, but it should be added immediately that the men in Cochin who had to execute Batavia's orders on several occasions took deviating decisions (Senff : sale of Cannanore to Ali Raja) or did not care about advice given by persons who were fully qualified to do so (Breekpot: supply of munitions to Haidar), the result of which often was that the parties drifted farther apart than would have been necessary even under the restrictive instructions from Batavia. Apart from the fact that the parties were to meet on a totally different basis, the discussions were, therefore, also to take place in an atmosphere which had become increasingly difficult. I feel bound to say that on grounds of their repeated clumsy action and stubborn attitude Breekpot and Senff are more to be blamed for the deterioration of the atmosphere than the High Government. For whereas the Governor-General and Council in mapping out the policy to be followed in Malabar, at any rate, can be said to have been free from obscure motives, though not from short-sightedness, the motives of Breekpot's and Senff's conduct in respect of Haidar Ali are sometimes far from clear, and their behaviour cannot always be said to have been in the interests of the Company, to say the least of it.

In this connection the case of the forgotten presents is perhaps the most striking example of clumsiness, neglect and stubbornness. The presents arrived during Breekpot's administration, and I suppose that, entirely in line with the attitude he was assuming at the time, he did not take great pains to forward them when circumstances made this less easy. Later on he had most probably forgotten all about it or perhaps remembered the existence of the gift only at so late a date that

222 Alexander's source, mentioning that the raja when pressed by Haidar requested the Company to tell the invader that he should be lenient to Cochin (P. C. Alexander, The Dutch in Malabar, p. 96) does not fit in with the Dutch correspondence on this matter (comp. pp. 75-6 supra). 
in his own interest he thought it better to leave things as they were. In any case he never mentioned the presents again, neither in his letters nor in his Memoir, so it is not surprising that only an outside cause brought the matter to light.

Meanwhile Breekpot certainly surprises us after his departure from Malabar by suddenly returning to the earlier idea of a treaty with Haidar.223 Little if any consistency can be perceived between his actual conduct of affairs while at Cochin and the policy he advised when back in Batavia. Is this just another example of his rather complicated mind, or is it the result of a bad conscience and must it be taken as an attempt to safeguard himself against possible reproaches later on if relations with Haidar deteriorated? Some people display great cleverness when it comes to seeking safeguards against the consequences of their own actions and Breekpot may well have been one of them. It is, however, also possible that he simply used the whole idea of a treaty with Haidar as a good excuse for not having complied with his superiors' instructions about demolishing the strongholds. But whatever his motives may have been, the inconsistency between his conduct and these proposals makes it impossible to regard the latter as a sincere attempt at a positive approach to relations with Mysore or, for that matter, to let Breekpot go down in the annals of history as the champion of such a bold policy.

Senff's period of office was so short and, moreover, coincided with an interruption in the direct contacts with Haidar that it would have been without any real significance for the relations between the Company and Mysore but for the sale of Cannanore. Earlier 224 some light has already been thrown on the probable motive for Senff's actual handling of this affair, but here it seems useful to consider for a moment its wider significance. This seems to me to be the fact that during the whole of the period covering the relations between Mysore and the Company Cannanore provides the only case in which the Dutch were able without any sacrifice on their side to offer something to Mysore as evidence of their wish to contribute to an extension of friendly relations. This opportunity was thrown away by Senff who in proposing to do so used two arguments 225 neither of which convinces us as particularly sound. One would have thought that Haidar should at least have had an opportunity to air his views on the offer of Cannanore. Moreover, even if from an economic or military point of view it

223 See pp. $68-9$ supra.

224 P. 72 supra.

225i P. 69 supra. 
would not have made any difference to the Dutch who was to buy which in itself is doubtful - these considerations should certainly have given way to the political implications of the matter. If proper account had been taken of this aspect it would have become obvious that Cannanore should have been disposed of to Haidar Ali and not to Ali Raja. By giving in too easily to Senff's proposal the High Government is to blame, particularly so as it should have considered the matter primarily in the wider field of Dutch-Mysore relations.

The conquest of Kanara in 1763 had put Haidar in possession of several ports and he immediately began to pursue an active naval policy in the best of South Indian traditions. A fleet was fitted out at the time of his conquests in Malabar in $1766^{226}$ and his navy soon became a force the Dutch had to reckon with.227 During the First AngloMysore War English forces from Bombay destroyed the Mysorean navy, but Haidar never abandoned his maritime projects and we have the authority of no less a person than admiral Sir Edward Hughes to form an opinion of their significance. In 1783, three years after Haidar's navy had once again been annihilated, he observed how fortunate indeed the British had been in achieving this success, for many large ships had been found under construction and once finished they might easily have blockaded Bombay during the absence of the royal squadron.228 From the point of view of Haidar's naval policy it is therefore most unlikely that in spite of the fact that several ports were at his disposal he would have turned down a possibility of increasing their number by adding Cannanore. He probably never found out that at one time there had been talk of selling the fort to him, for if he had he would almost certainly have used the opportunity of introducing at some later moment this case which could so easily have been magnified into another unfriendly gesture of the Dutch.

In a way this is exactly what happened in the matter of the lost presents, for while Haidar must have realized for a long time that something was amiss in this respect, he continued to express friendly feelings towards the Dutch. ${ }^{229}$ Not until his Malabar policy became once more aggressive did he take up the matter as a convenient reason for feeling insulted.

But although the sale of Cannanore had no evil consequences in the

2286 See p. 29 supra.

227 See pp. 47 and 60 supra.

228 See H. Richmond, The navy in India 1763-1783 (London, 1931), p. 428.

220 See p. 71 supra. 
sense of rousing Haidar even more, it did not improve the situation either as it might have done if matters had been handled differently. As it was, the position in 1775, the year in which the second embassy to Haidar was to take place, was far less favourable for the Dutch than in 1766. 
CHAPTER III

\section{YEARS OF GROWING ESTRANGEMENT AND HOSTHLIIES, 1775-1781}

The envoys to Seringapatam were, as in the case of the embassy to Calicut of 1766, provided with detailed instructions how to travel and what replies to give to possible questions. In several respects there is considerable resemblance between these two sets of instructions, the main difference being that this time the ambassadors were allowed to offer arms in exchange for the products of Haidar's dominions. There is no reason, however, to dwell on the instructions of 1775 as the nature of the discussions at Seringapatam turned out to be rather different from what Moens had expected and several points on which Saffin and de Riberto had been briefed therefore appeared irrelevant.

As in 1766 the envoys could profit by Surion's presence, for this merchant had meanwhile changed his decision and would also undertake the journey to Seringapatam. Surion was in a peculiar position and Moens clearly saw this as appears from his remark that for several reasons he would not dare to entrust an official commission to Surion alone as he had to keep friends with Haidar for the sake of his interests at Calicut and he therefore might easily tell too much about Dutch affairs. ${ }^{230}$

On 23 February 1775 Saffin set out for Seringapatam, going by boat to Chetvai where de Riberto joined the party which then proceeded overland to Calicut. They had been instructed to request Srinivasa Rao at Calicut to send some guides along with them to Seringapatam. But when they arrived on 28 February they learned that Srinivasa Rao had left for the south where some Nairs had risen in revolt. His deputy immediately wrote to him about the arrival of the embassy, and on 7 March he informed the commissioners that Srinivasa Rao was returning within five or six days. If, however, they could not wait till then they were allowed to proceed on their journey, the guides they

230 L.f.M., 1775, II, Moens to Batavia, s.l., October 10, 1774. L.f.M., 1776, I, Moens to Batavia, s.l., May 12, 1775. 
needed being ready. The ambassadors decided to leave Calicut on the 10 th as this would give them an opportunity to obtain some new coolies instead of those who had disappeared during the journey, or had fallen ill. Surion travelled together with the Dutch party and they all reached Seringapatam on 19 March.

Apparently Saffin and de Riberto were not the sort of men who are open to fresh impressions in an unknown country. The reader who expects to find in their report on the mission remarks and observations about the country-side and its people feels disappointed when he sees that nothing is mentioned in this connection, not even the route that was followed. It is only stated that they arrived in the capital after having travelled along a very heavy road.

In Seringapatam they took residence in a house allotted to them by one of Haidar's servants. In the evening of the next day, when they had been notified to keep themselves ready for an audience, a person named "Medij Alichan" 231 called on the ambassadors. He explained that he had been to the Coromandel coast recently, and had been commissioned by Haidar to deal with the affairs of the Dutch. In proof thereof he showed them two letters written in Dutch and signed by van Vlissingen, the Governor at Negapatam. The commissioners requested him to acquaint them with the contents of these letters, but Mehdi Ali Khan replied that he had no order to do so. After he had made a list of the presents that had been brought for his master he took leave. Afterwards Saffin and de Riberto had their first audience with Haidar on which occasion the presents were inspected. The gifts which de Riberto had taken to Calicut in July of the year before were also there. Haidar requested the commissioners to operate the "peepshow", one of the presents, and he and his countrymen greatly enjoyed the performance, especially when a naval battle was shown.

In the evening of 24 March the envoys had a second audience. This time Haidar ordered everyone not concerned to leave the hall except the person who was fanning him and Mehdi Ali Khan. Haidar told the commissioners that the appearance of his forces in the territories of the Company and of the raja of Cranganore had been without his

231 As we shall see on p. 94 infra, the Governor at Negapatam wrote in January 1774 about having been in contact with this person whom he called „Mahoedoe Allichan". According to Wilks Haidar's ambassadors "Aly Zeman Khan" and "Mhedee Aly Khan" arrived at Madras in December 1773 (M. Wilks, Historical Sketches of the South of India, II (London, 1817), p. 220, nt.). „Medij Alichan” therefore seems identical with Mehdi Ali Khan. 
knowledge and that it would not happen again. As he seemed to be in a friendly mood the envoys turned the conversation on the supply of arms. Haidar agreed to the proposal to write Moens what he would need. The Company could get rice, sandalwood and cardamom in exchange, and preferential treatment to the Dutch would be given if an agreement could be reached. Haidar then asked Mehdi Ali Khan to convey the contents of the letters from Negapatam. Van Vlissingen was said to have offered Haidar his friendship, whereupon Mehdi Ali Khan had been sent to him to discuss an alliance. When, however, van Vlissingen had replied that he could not go any further without instructions from Batavia, Haidar had approached Moens about sending a deputation, trusting that an alliance could be reached on the basis of some points which should be presented to the Governor-General. Haidar told the ambassadors that he was now going to draft letters for the Governor-General and Moens. He did not broach subjects the discussion of which might have been somewhat awkward for the Dutch, such as the relations with Cochin and Travancore, the question of the "Sandy land" 232 and the fact that the Dutch had not sent an embassy at the same time as the other European nations. He told Saffin and de Riberto that he would not speak about former affairs.

The envoys were received in a farewell audience on 5 April, on which occasion Haidar requested them to ask Moens to write to Ceylon for some elephants of the largest species. He also would like to get fifty ship-builders and blacksmiths in order to build some ships at Calicut.

On their way home the commissioners arrived at Calicut on 13 April. Illness and fatigue among the coolies caused Saffin and de Riberto to proceed on their journey to Chetvai by sea. They arrived at Cochin on 21 April.233

Haidar's letter to the Governor-General stated that in 1774 van Vlissingen had spoken with Mehdi Ali Khan about friendship with Mysore, and Haidar felt sure that the Governor would have reported these discussions to Batavia. He further expressed his astonishment that the Company had not tried more vigorously to regain the posses-

232 Comp. p. 39 supra.

233 L. f. M., 1776, I, Moens to Batavia, s.l., May 12, 1775. The instructions for, and the report of the envoys have been inserted in this letter. Moens had to open Haidar's letter to Batavia because it had become wet during the voyage to Chetvai and otherwise might have become completely illegible. 
sions which it had lost to Muhammad Ali.234 According to him the Company had enough munitions and money to wage a long war. Finally, Haidar requested the Governor-General to sign the treaty which he had drafted and to return it to him whereupon he would also sign it. The draft consisted of nine articles, seven of which referred to the lending of mutual assistance. In article 8 it was stated that in case the previous articles were accepted Haidar would undertake to supply the Company with all the rice, cardamom and sandalwood of Coorg. According to the 9th article the Company should pay for these products with the supply of military stores.

The two letters had been written in French. The writer, a French officer in Haidar's service, seemed to have been used for this work only accidentally and not out of habit, and Moens thought, therefore, that several expressions in the letter as well as in the contract should not be taken too literally. For instance, it was unlikely that article 6 , saying that the troops which Haidar would demand were to be sent to him by order of the Governor-General, correctly reported Haidar's opinion as he would not be willing to await Batavia's consent in case he needed aid.

Although Moens was satisfied that the mission, by removing Haidar's coolness, had answered its first purpose, he recognized its failure in another respect, for the Dutch had not succeeded in entering into a treaty of friendship as had been Batavia's aim. Nevertheless, Moens had made up his mind to maintain the restored contact with Haidar. This did not imply, however, that he thought that the Company should come to terms with Haidar at any cost. On the contrary, he observed in his letter of 12 May 1775 to Batavia that he need not remind the High Government of the great difficulties that would result from an alliance as proposed by Haidar. The Mysorean ruler was too suspicious and too intelligent to have a European nation prescribe the law to him in the same way as the British did to Muhammad Ali. He had so many enemies that he would never be left in peace, and in case the Company entered into his proposals there would soon be a war against Muhammad Ali and the English. Yet, Moens thought it advisable not to show the Company's dislike too clearly to Haidar. Instead of immediately turning down his proposals, as far as they related to a

234 This alludes to the fact that after Muhammad Ali had found English support for his aggressive policy against the raja of Tanjore, who was subsequently deposed in 1773, the Dutch had been obliged to return to him some districts which the raja, when hard pressed, had leased to the Company. 
defensive treaty, it might be better to leave him in some doubt. Moens suggested that the Governor-General might reply that it was necessary to consult The Seventeen about an alliance like this. Meanwhile, the High Government might draft a commercial treaty on the basis of the articles 8 and 9 and propose to Haidar to conclude such a treaty first. Even if the only result would be that he was kept in conversation and that his friendship was maintained and cultivated, this was quite enough for the time being. Haidar was an aged man, and besides, it was unknown what turn events might take with him in the near future. In this way about three years would elapse before it became necessary to come to an arrangement. Moens thought it most important that the Company should remain closely allied with Travancore. RamaVarma knew that as things stood he could not cherish any hope of maintaining himself unless he got some powerful assistance. If the Dutch did not give him this assistance he would associate himself more closely with the British, and the Dutch would lose the pepper. Moens could quite well imagine that Haidar would give up his plan to attack Travancore if he noticed the Company's interest in Travancore's existence. The Cochin Governor wrote that he had arrived at the conclusion that a closer alliance with Travancore would be necessary in future if the Dutch were to keep the supply of pepper. Now circumstances only speeded up the development. ${ }^{235}$

Moens started to carry out the new policy by carefully heartening the raja of Travancore, saying that an attack on him by Haidar was unlikely so long as he knew that the Company was the raja's friend. It was in the raja's own hands to keep up this friendship by a loyal fulfilment of the pepper-contract.236 Whereas in July 1775 Moens still seemed to think that his new policy would prevent Travancore from being won over by the British, he had to admit in November of the same year that Rama-Varma had applied to the English for assistance against Haidar, when during the previous months an attack on Travancore seemed imminent. Consequently, less pepper had been delivered to the Dutch than Moens had expected to receive. Nor did matters with respect to Haidar proceed as well as Moens had hoped. New tribute had been demanded from the rulers of Cochin and Cranganore. Moens ignored the demand made on the first but he tried to avoid the payment of a second tribute by Cranganore by writing to the Governor

235 L.f. M., 1776, I, Moens to Batavia, s.l., May 12, 1775.

236 L.f.M., 1776, I, Moens to Batavia, s.l., July 13, 1775. 
at Calicut on 21 September 1775 asking for an explanation, meanwhile pointing out the special relation which had existed between the Company and Cranganore since 1717. Srinivasa Rao, a Hindu, had been replaced as Governor by the Muslim Sardar Khan, a callous person according to Moens. Sardar Khan had commissioned Haidros Kutti to demand 50,000 rupees from the raja of Cochin and 25,000 from Cranganore. Previously, in August, Moens had received a letter from Haidar requesting him to apply to the Governor-General for permission to send 200 foot-soldiers and 100 cavalry-men. In his reply of 24 August 1775 Moens acknowledged receipt of the letter and sent two long muskets as had been requested by Haidar through the envoys, and which had recently arrived from Ceylon. Soon after he had sent his letter of 21 September to Sardar Khan Moens received a letter from this person. With it was forwarded a letter from Haidar, who now asked for 500 men and two new muskets as those he had received were no good. In another letter which arrived at Cochin on 21 October Sardar Khan explained that he dealt with the Cranganore affairs according to Haidar's instructions. If Moens had a letter from Haidar intimating that no money would be demanded from Cranganore and that last year's demand had been unjustifiable, he should show it. Moens, thereupon, wrote to Haidar saying that he failed to see how his instructions to Sardar Khan were to be reconciled with his pledge regarding Cranganore. After that no more demands were made upon Cranganore. Moens was in no doubt that this case was being deferred till Batavia's reply reached Haidar. Every now and then inquiries were made on behalf of the Nawab whether ships from Batavia had not yet arrived. ${ }^{237}$

At the turn of the year Moens received a letter from Batavia of 20 September 1775, but it had been written before Haidar's proposals had been received by the High Government. It approved of Moens's conduct concerning Haidar and he was instructed to send envoys if this had not been done already. At about the same time a letter from Haidar reached Moens from Negapatam. In July a letter of the Nawab to van Vlissingen had been received at Cochin and at that time Moens supposed that two letters had been misdirected, ${ }^{238}$ but he now thought that it had been done on purpose so as to inform van Vlissingen indirectly of what had been proposed to Batavia. In both letters Haidar

237 L.f. M., 1776, I, Moens to Batavia, s.l., November 18, 1775.

238 L. f. M., 1776, I, Moens to Batavia, s.l., July 13, 1775. 
spoke of envoys who should be sent to him to settle affairs. He seemed to intimate in a haughty way that his proposals should be accepted if the Dutch wanted to keep his friendship. There was, however, no imminent danger, as Haidar had turned his attention to the north in order to take advantage of the war between the English and the Marathas. ${ }^{239}$

In consequence of Haidar's letter to van Vlissingen which had been forwarded by Moens, the Governor at Negapatam explained to the High Government that there had been some correspondence between him and Mehdi Ali Khan but never an interview.240 In January 1774 he had already reported that Mehdi Ali Khan while staying at Nagore ostensibly to buy elephants for Haidar, had written that he would like to meet him, but that until then he had found no opportunity to carry out this plan, because two men who had been placed at his disposal by Muhammad Ali continually spied upon him.241

During the rainy season of 1776 Sardar Khan again and again demanded tribute from the raja of Cochin who, being under the impression that this was done without Haidar's knowledge, each time sent envoys to the Nawab. They returned with messages that the raja would not be molested. The last time it was added, however, that as Haidar was short of money the raja should send him 5 lakhs of rupees. A few days later, in the end of August, Sardar Khan invaded the northern part of the Cochin territories, and as the raja had made no preparations whatsoever to resist an attack, he gave orders to surrender that part of his country. He concentrated his troops to the south of the river of Cranganore to which region Rama-Varma also took the main part of his army.

Fresh payments had also been demanded from Cranganore and Moens saw no possibility of preventing Haidar's troops from invading the country of Cranganore if matters should come to a head. Bands of robbers already caused great annoyance and Moens therefore asked Falck to send him more troops. 242

239 L. f. M., 1776, I, Moens to Batavia, s.l., January 4, 1776. Interference in the internal affairs of the Marathas by the English at Bombay had led to this Anglo-Maratha War which had started in 1774 . Peace was not definitely restored until 1782.

240 L.f. Cor., 1776, I, Van Vlissingen to Batavia, September 16, 1775.

241 L. f. Cor., 1774, II, Van Vlissingen to Batavia, s.l., January 31, 1774.

242 L. f. C., 1777, I, Moens to Falck, s.l., September 27, 1776. 
Soon afterwards the raja of Cochin came to an arrangement with the invaders by promising to pay a large tribute and it therefore seemed that the danger was over, at least for the time being. At the raja's request the Cochin Council decided to give him 20,000 rupees towards the first instalment of the tribute after Rama-Varma had made a contribution of 50,000 rupees. All this was done to maintain peace and even no protest was made against the fact that Cranganore's ruler was included in the arrangement between the Mysoreans and the raja of Cochin. But it was useless, for now Sardar Khan turned against the Company itself by requiring evidence and accounts regarding the "Sandy land" near Chetvai, the revenue of which district in the dominions of the former Zamorin had been sequestrated since 1762. Moens gave him the information in a letter of 30 September but this did not seem to satisfy Sardar Khan, for he took a detachment to the neighbourhood of Chetvai. Two persons who were successively sent to him by the resident of Chetvai in order to inquire what was the matter, were detained and a demand was made of twenty years revenue of the district and in addition the amount of the original debt of the Zamorin from which the sequestration had resulted. Moens wrote a letter of protest to Sardar Khan but before this letter of 11 October 1776 could have reached its destination the resident at Paponetty reported to Moens that part of the detachment had invaded the region of Paponetty and that he had retired to Cranganore. The Company's warehouse had been broken open and several houses been set alight. Sardar Khan then moved to the territories of Cranganore and sent a letter to Moens explaining that he had not received any reply to two letters regarding the "Sandy land" and that now, on order of Haidar, he had marched into the Company's possessions. He added that Haidar wished to live in peace with the Company but that he needed free passage through the Company's territories in order to make war against Travancore.

Moens replied by offering his mediation in the dispute between the Mysoreans and Travancore, pointing out that in 1766 Haidar had once asked for the Company's good offices. In a letter of 17 October Moens made representations to Haidar himself. Until then, as Moens wrote to Batavia on 28 October, the events on the Company's territories could, to some extent, be considered the consequence of the pretended plan to march against Travancore. But the situation changed when it was reported that an attempt was made to take the Cranganore fort. Moreover, Sardar Khan wrote another letter in which he stated that the "Sandy land" belonged to Haidar and that he had taken possession 
of it. It then became clear that the region of Paponetty 243 and probably the whole of the region from Cranganore to Chetvai had been included in the territory to be ceded. This time Sardar Khan denied that he wanted to wage war against Travancore and he now demanded tribute from the Company as a compensation for his war expenses of 5,000 rupees a day.

As Moens wrote to Batavia, this new development required another policy than that of neutrality as prescribed by the High Government, and he did not hesitate to strengthen the ties with Travancore and Cochin. The fact that the raja of Cochin seemed likely to change sides if the Cochin Council postponed its decision any longer made the Council pass a resolution on 13 October 1776 that a further penetration should be resisted in coalition with Travancore and Cochin. A change of sides by the raja of Cochin would mean that the provision of victuals for the town might easily be cut off. Both rajas signified their approval of a combined resistance, but Moens soon found out that their assistance was not of much use. Yet, some small successes were gained. The enemy's plan to take the Cranganore fort by surprise had been foiled and troops stationed near Ayacottah retired to Paponetty when combined forces of the Company and Travancore approached.

Meanwhile, Moens kept up the correspondence with Sardar Khan so as to gain time. Haidar had to keep his main army in the north for fear of an invasion by the Marathas or the Nizam. If the Company wished to make peace with him without waging an offensive war, it would, as Moens wrote to Batavia, have to give up the region of Paponetty and its claim to the districts in between Cranganore and Chetvai. Moreover, it would be necessary to maintain a state of defence for ever. He requested Batavia to send instructions as well as troops and ships. ${ }^{244}$

Earlier Moens had already applied to Falck to send more auxiliaries, and on the 4th of November 1776 some 750 men arrived at Cochin from Colombo. Subsequently a plan was made to drive the enemy northwards in a combined action of troops of Travancore, Cochin and the Company. Preparations took up much time in consequence of the complicated system of supplies. While these were still in progress

243 Moens supposed that someone had told the Mysoreans that the contract of 1758 with the Zamorin, in which this region had been given up to the Company, had never been signed.

244 L.f.M., 1777, I, Moens to The Seventeen, October 12, 1776; do., Moens to Batavia, January 2, 1777. L. f. M., 1777, II, Moens to Batavia, October 28, 1776; do., Moens to Sardar Khan, September 30, 1776. 
reports from Chetvai came in that this stronghold could not be held much longer. It therefore became imperative to relieve the place without delay. For this purpose about 180 soldiers were embarked on the "Hoolwerf" and small vessels were provided for disembarking the men and landing the stores and provisions for the relief of Chetvai. They sailed from Cochin in the morning of 12 November and came off Chetvai at noon. The instructions read that a landing should be attempted immediately and the commanding officer wanted to do so, but the captain of the "Hoolwerf" raised technical objections and the result was that the attempt was postponed till the next day. Sardar Khan, who at the time was at Paponetty with the main part of his army, was thereby enabled to lay an ambush for the landing detachment which was utterly defeated. On 15 November Chetvai surrendered. The condition that the garrison should be allowed to march out and be conducted to Cranganore was not fulfilled and the soldiers were sent first to Calicut and later to Seringapatam. In consequence of the fatal result of this action it was decided to act on the defensive for the time being. 245

Whereas Rama-Varma had first declared to Moens that owing to his relations with Muhammad Ali and the British he was unable to attack the Mysoreans outside his own dominions, 246 Moens now received a proposal from him and the raja of Cochin to expel the Mysoreans from Malabar by joining forces with the Zamorin and the chief of Kolattiri, who were in exile, and with Ali Raja, who seemed to become tired of Haidar's yoke. Moens, however, did not like the idea of unchaining a large-scale war, the main reason being that one could never be sure of the Indian rulers. He, therefore, preferred to remain united with Travancore and Cochin only, but at the same time thought it useful to take up contact with the Zamorin and Haidros Kutti, who became anxious to save his skin. Through them he hoped to cause a disturbance in the north which might induce Haidar to make up the quarrel by pretending that Sardar Khan had exceeded his authority. Information received by Moens pointed to the fact that Haidar regretted the aggression against the Dutch, because it had lessened his chance of surprising Travancore. 247

245 L.f. M., 1777, II, Moens to Batavia, January 2, 1777. J. S. Stavorinus, Voyages to the East-Indics, III (transl. by S. H. Wilcocke, London, 1798), pp. $256-60$.

246 L.f. M., 1777, II, Moens to Batavia, October 28, 1776.

247 L. f. M., 1777, II, Moens to Batavia, s.l., January 2, 1777.

V.K.I. 31 
Just a week after he had reported on the situation in several letters to Batavia, Moens received from the High Government a letter and presents to the value of almost 3,900 guilders in reply to Haidar's proposals and gifts of 1775 . He immediately informed Haidar of this by a letter of 10 January 1777 . After several weeks the Nawab responded by sending back de Riberto and the commander of the troops sent to relieve Chetvai who had been taken prisoner, ${ }^{248}$ and by offering his friendship in a letter in which he attributed the dispute to a misunderstanding, at the same time blaming the Dutch for its origin. Moens thereupon dispatched in March the letter and presents to Calicut and asked whether Haidar would send two envoys or whether he should nominate two persons to go to Seringapatam in order to settle the dispute. Thereafter, however, nothing happened as Haidar did not even bother to send a reply. 249

There are two questions in the narrative so far which require more attention. First, it may be asked whether Haidar's conduct with respect to the Company was totally unjustified. When reading through the Dutch sources we find indications that his reasons for taking possession of the districts near Chetvai were not so far-fetched if it is realized that at the time he was ruler of the Zamorin's dominions. It may be remembered here that already in the instructions for the embassy of 1766 Saffin and Zimmerman were advised not to broach the subject of the "Sandy land" and its revenues unless Haidar mentioned it. Was it only an attempt not to complicate matters? It takes on another complexion when we read that these districts in between Chetvai and Paponetty, although said to have been given in pledge, had actually been sequestrated by the Company in 1762 without the Zamorin's permission. When the Zamorin was at war with Travancore and Cochin, the Dutch had taken possession of the region in connection with a balance of expenses of war mentioned in an unsigned contract of 1758 which the Zamorin did not want to pay off. Moens himself was of the opinion that it was clear that the Dutch had little right to the area

248 Practically all soldiers taken prisoner entered the Nawab's service for fear of ill-treatment and lack of food.

249 L.f. M., 1778, I, Moens to Batavia, s.l., March 7. 1777; do., Moens to Batavia, March 7, 1777; do., Moens to Batavia, s.l., May 5, 1777. Stavorinus op. cit., pp. 267-9. "Memoir written in the year 1781 A. D. by Adriaan Moens, Extraordinary member of the Batavia Council, Governor and Director of the Malabar Coast, Canara and Vingurla, for his successor", Sel. Dutch Records Madras No. 2 - hereinafter cited as Mem. Moens -, pp. 66-7. 
and that Haidar was entitled to take possession.250 It is therefore not surprising that Haidar proceeded to action when once more he received the impression that the Dutch did not appreciate his ideas of friendship and collaboration. For, after what had happened with the presents from Batavia in 1767, the delay in the reply to his proposals of 1775 must have deepened that impression. This delay was mainly due to the fact that the ship which had taken Haidar's proposals and presents to Batavia had an exceptionally long voyage,251 but according to Stavorinus there had also been some negligence on the side of the High Government.252 Although Moens had done his best to explain to Haidar why it took such a long time before the answer from Batavia could be expected he could not prevent him from becoming impatient and irritated. 253

My conclusion is that, in the light of these circumstances, Haidar's action against the Company in 1776 is understandable and that to a large extent the Dutch had to blame themselves for what had happened.

The second point concerns the relations between the Company and the kingdom of Travancore during this period when for the first time the Company, rather than Travancore, was more in danger and in need of support. Here too, former events had put the Dutch in a false position, and once again it is Moens who admitted this when he reported to Batavia. In a letter to Rama-Varma he said it was selfevident that now they should act together in resisting the farther advance of the Mysoreans.254 Rama-Varma seemed to accept this idea but pointed out that on account of his other obligations he was unable to wage an offensive war. Somewhat later, however, he seemed to have changed his opinion and proposed to join forces with other chiefs so as to expel the Mysoreans from Malabar. By that time, however, the Dutch had met with the rebuff at Chetvai and did not wish to risk the remainder of their troops. Besides, Moens suspected that Rama-Varma was unwilling to proceed from words to deeds, and this proved to be right when shortly afterwards Moens pretended that he was going to attack the enemy and asked whether the rajas of Travancore and Cochin were ready to join. They then appeared to have no intention to do so and Rama-Varma used his influence to dissuade

\footnotetext{
250 L.f. M., 1778, I, Moens to Batavia, March 7, 1777.

251 Mem. Moens, p. 62.

252 Stavorinus, op. cit., p. 253.

263 Mem. Moens, pp. 62-3.

254 L. f. M., 1777, II, Moens to Batavia, October 28, 1776.
} 
Moens from attacking without their assistance. Of course, Moens left matters as they were for he had never, in fact, intended to act but he now knew for certain how little he could depend on his allies.255 Stavorinus, who was at Cochin at the time, thought that Rama-Varma's earlier promises were only made "to encourage the Company to involve themselves in difficulties, and to keep himself entirely out of the scrape", 256 and probably Moens at first was of the same opinion. Later on he may have changed his view when he noticed that Rama-Varma did not want him to attack all by himself. It is also possible, however, that Rama-Varma at first, indeed, wished the humiliation of the Dutch but that he changed his mind when his fear of the consequences for himself grew.

On the other hand, I cannot agree with those writers who make it appear that Moens, had he had his hands free, would have turned against Travancore and united with the Mysoreans. Alexander, for instance, writes :

"Left to himself, Moens would have joined with Hyder Ali in his attempt to subjugate Travancore."

Instead of giving some argument of his own for this statement he merely quotes Day in the following words:

"Day observes: "Had this ambitious capable Dutch Governor of Cochin been at this period possessed of sufficient troops at his own disposal, untrammelled by Batavian orders, there can be little doubt, he would have joined the Mysoreans. Had he done so, Travancore must have fallen and the Cochin state would have become a desert. Then who could have foretold what course events on the western coast would have taken?" " 257

To my mind, there is not the slightest indication that Moens would have preferred a united action with Haidar to the policy he actually carried out. Apart from the fact that on several occasions he planned aggressive actions against the Mysorean invaders, his whole policy regarding Haidar had been one of cautious mistrust, practically from the beginning. In this connection it may be remembered 258 how he advised the High Government in 1775 to let negotiations drag on. Sometimes Moens like Breekpot had his dreams of a powerful and

\footnotetext{
255 Mem. Moens, p. 66.

256 Stavorinus, op. cit., p. 265.

257 P. C. Alexander, The Dutch in Malabar, p. 101. Comp. F. Day, The Land of the Permauls, or Cochin, its past and its present, p. 153.

258 See pp. 91-2 supra.
} 
dominating Company in Malabar, but these had a different startingpoint. Whereas Breekpot thought his dreams could be realized through Haidar's assistance, Moens was of opinion that if only the Dutch could rely upon the aid of Travancore and Cochin they might be able to expel the Mysoreans and become masters of Malabar. 259

During the whole of 1777 the general situation remained unchanged. No new hostilities occurred between the Dutch and the Mysoreans. The latter had to contend with raids of the Nairs in the Calicut region whereas Haidar's main army was kept busy in the north fighting against the Marathas and others.260 Moens received a letter from Batavia of 25 June 1777 in which his policy with regard to Haidar was approved of on the whole and which contained instructions to act on the defensive for the present. 261 The High Government stuck to this decision when on 29 August 1777 the letters of 2 January and 7 March 1777 of Moens were being dealt with. In his secret letter of 7 March the Governor of Cochin had asked whether he ought to continue the war if it should appear that Haidar was unwilling to cede the conquered districts. It was now considered that these districts and the fort of Chetvai were not so important as to risk a complete war for the sake of getting them back. Moreover, the need of troops in Java $\mathbf{2 6 2}$ made it impossible to send reinforcements to Malabar. It was, therefore, thought most advisable to let Haidar keep what could not be taken back from him without superior forces. Nevertheless, Moens should maintain to the utmost the Company's claim to the districts unless he noticed that peace could not be preserved otherwise. In that case he should no longer press for restitution provided that Haidar demolished the stronghold of Chetvai and paid damages to the Dutch for their losses as a result of his invasion. If necessary, these conditions might even be dropped.263

Moens, however, was not the type of person to reconcile himself to the situation as it had developed. By the end of 1777 he started preparations for an attempt to recapture Chetvai and the lost districts. $\mathrm{He}$

258 L.f. M., 1777, II, Moens to Batavia, s.1., January 2, 1777.

$\approx$;0 Mcm. Moens, p. 68. Comp. C. Hayavadana Rao, Histor.j of My'sore, III, pp. 248-55.

281 L. f. M., 1778, I, Moens to Batavia, s.l., August 28, 1777.

262 Reinforcements received from Holland in 1776 were used in East Java where the Company was then reaching the final stage of its conquest (comp. M. L. van Deventer, ed. of De opkomst van het Nederlandsch gezag in Oost-Indië, XI, p. XXXII).

283 Secret resolutions Governor-Gencral and Councillors, 1774-81, August 29, 1777. 
countered the refusal of the rajas of Travancore and Cochin to supply him with coolies for the troops by making use of bullocks which he had specially trained for the purpose, and on 8 January 1778 an expeditionary force set out from Cranganore. The enemy evacuated the palace of the raja of Cranganore and Paponetty, and fell back on Chetvai. Correspondence found in the palace showed that the attack had been expected. In the evening of the 10th the troops arrived before Chetvai. During the next day the fort was bombarded, but the defence was well organized and daily more reinforcements of the enemy arrived. The danger of coming between two fires led to an assault in the early morning of the 15 th but after an initial success the native troops retreated and the assault had to be abandoned. Thereupon Moens sent instructions to raise the siege and on 19 January the troops returned to Cranganore having left behind seven guns. ${ }^{264}$ An outpost was left in the palace of the raja of Cranganore but an attack by the Mysoreans on 3 March 1778 forced its retreat to an entrenchment which had been erected before Cranganore in December 1776.265 After this no more fighting took place.

As there was no indication whatever that a settlement could be reached in the near future, Moens thought of a way by which the Company would at least avoid incurring further expenses on account of the situation. For this purpose he wanted to make use of the position of the Paljetter. By now Moens had found out that already in 1766 this minister of Cochin had played a doubtful part in his dealings with Haidar, and the prime minister of Travancore had recently warned Moens that the Paljetter could not be trusted. Moens's idea now was that the Paljetter should try to rent the districts which the Mysoreans had aken away from the Dutch. The result would be that the Mysorean troops were withdrawn from the region and it would no longer be necessary to keep an expensive army in and around Cranganore. At the same time the Dutch claim to the lost districts could be maintained. In a way this solution would even be a better one than making peace with Haidar, for the latter would mean giving up the districts altogether, besides keeping on a considerable army. Meanwhile the outcome of Haidar's war against the Marathas could be awaited, and apart from this Moens thought it most likely that Haidar had not much longer to live as he was an aged man. 266

264 L. f. M., 1778, I, Moens to Batavia, January 2, 1778. L. f. M., 1779, I, Moens

to Batavia, s.l., February 26, 1778. Mem. Moens, pp. 68-9.

265 L. f. M., 1779, I, Moens to Batavia, s.l. March 10, 1778.

206 L. f. M., 1779, I, Moens to Batavia, s.l., April 24, 1778. 
Moens's plan, doubtless more ingenious than scrupulous, could not be realized however, as even the envoys of the Paljetter could not mention the Dutch cause at Haidar's court without meeting with a rebuff. Moens was even told that Haidar suspected that instructions to conclude an offensive and defensive alliance with him had been received at Cochin in time but that the Governor, being unwilling to execute them, had pressed Batavia to send other directives.267

Meanwhile, the political situation in southern India underwent a change by the outbreak of the war between England and France in 1778 , and by the threat of an invasion of the Carnatic by Haidar. In a letter of 12 November 1778 Falck expressed as his opinion that nobody could trust Haidar and that the British and Muhammad Ali would be unable to prevent the Mysoreans from invading the Carnatic and Madura. In this case the Dutch factories along the coast of Coromandel and Madura would be in danger of being surprised. Falck, therefore, asked Batavia to let him know soon whether in such a case Muhammad Ali and, if necessary, the British as well could be approached with the request to cover with their troops the Dutch possessions in Coromandel, whereupon the Company would send all available troops from Malabar and Ceylon to Madura. The advantage was that the Dutch troops would be nearer to Ceylon whereas it would be possible to send troops from Madura via Travancore to Malabar if, what was unlikely, Haidar's troops near Cranganore would renew their action. The result might be enmity with the French but it now seemed more important that Muhammad Ali, who during recent years had behaved well towards the Company, should maintain himself. By helping him in this way he would certainly in future become even more friendly disposed towards the Dutch. 268

So here we see that as in 1766 the situation in Falck's opinion required abandoning the policy of neutrality. But whereas in 1766 he had advised choosing between Haidar and Muhammad Ali as possible allies, ${ }^{269}$ Falck now considered only the latter to be a suitable candidate.

The High Government dealt with the matter on 11 January 1779 and did not dissent from the idea of approaching Muhammad Ali on the question of the defence of Madura. But strict neutrality had to be observed in the war between the British and the French. At the same time it should be attempted to conclude peace with Haidar, and Falck

207 L. f. M., 1780, Moens to Batavia, s.l., April 25, 1779.

268 L.f. C., 1779, I, Falck to Batavia, s.l., November 12, 1778.

269 See p. 34 supra. 
was instructed to take up correspondence with Moens about this point. The Governor at Colombo was also qualified to advise van Vlissingen in case Haidar might proceed to the east thus endangering the Dutch factories in Coromandel. If the worst came to the worst the aid of the British and also of Tanjore should be called in.270

After Falck had received these instructions on 10 April 1779 rumours that troops of Haidar and the Marathas were approaching the Carnatic reached him. He requested van Vlissingen to inform him about the situation and to state his opinion on Falck's plan to offer Muhammad Ali a Ceylonese detachment for the defence of Madura. At the same time he asked for Moens's opinion about the possibility of making peace with Haidar. ${ }^{271}$

Van Vlissingen replied that indeed Haidar had advanced at first but that he suddenly had retreated, since, as was said, he was afraid of the possibility of an attack on Seringapatam by the Marathas who had not yet come to terms with him. The Governor at Negapatam thought that Haidar was not really dangerous as long as he could not rely on the assistance of the Marathas. His conclusion, therefore, was that Falck's plan of defence should not yet be put into practice. Besides, he had objections against the plan because he did not trust the British and thought that they might inform Haidar of the Company's proposal to Muhammad Ali. The result could then easily be that not Muhammad Ali's dominions but those of the Company either in Malabar or Coromandel were invaded. 272

Moens in his reply to Falck referred to his secret letter of 25 April 1779 to Batavia. Already since the end of 1778 there had been rumours that Haidar had died and Moens, by now, was practically convinced that they contained the truth. 273

It was not until the second half of 1779 that Moens knew for certain that Haidar was still alive. One of his spies, who had been at Seringapatam at the same time as the missionary Schwarz, who had gone there on behalf of the English at Madras, had seen Haidar walking in his capital. Moens wrote to Batavia that he still had not succeeded in

270 Secret resolutions Governor-General and Councillors, 1774-81, January 11, 1779. The raja of Tanjore, deposed in 1773, had in the meantime been reinstated.

271 L.f.C., 1780, I, Falck to van Vlissingen, s.l., April 23, 1779; do., Falck to Moens, s.1., April 23, 1779.

272 L.f.C., 1780, I, Van Vlissingen to Falck, s.1., May 28, 1779.

273 L. f. C., 1780, I, Moens to Falck, s.l., May 16, 1779. 
finding possibilities to come to an arrangement with the Nawab.274 The situation in Malabar did not undergo great changes although the Nairs were very active. Sardar Khan, who in 1777 had been summoned to Seringapatam,275 returned to the coast during 1779 but lost a quarter of his troops before reaching Calicut. ${ }^{276}$

The outbreak of the Second Anglo-Mysore War in the summer of 1780 soon involved the Dutch in Coromandel in great difficulties. On 22 July a Mysorean detachment of about 5,000 horse suddenly looted Porto Novo, and the Dutch and Danish trading posts in this place were not spared. The enemy left that same night taking along the Dutch resident Topander with two of his assistants and seventeen camels loaded with goods belonging to the Company. When hearing about this raid van Vlissingen sent a messenger to the commander of the detachment with a letter in which he requested the release of the prisoners. ${ }^{277}$ As this produced no effect a letter was dispatched to Haidar on 8 August in which the request was repeated. As a result of the invasion trade had come to a standstill.278

In September Topander wrote that he and the Danish resident of Porto Novo were being held to ransom for 10,000 pagodas each. A personal servant of van Vlissingen, Iroelappa, who had also been taken prisoner at Porto Novo, was released and returned to Negapatam by the end of the same month, bringing along proposals which, as he said, Haidar had instructed him to bring to the notice of the Company. The Nawab wished a written agreement in which the Dutch bound themselves to assist him with troops and military stores. They would have to consider his enemies their own and vice versa. In case the Company needed sea-ports or other territories Haidar would procure them. If the Company was unwilling to accept his terms he would take over Negapatam and its dependencies by force. Nothing was said about the prisoners, but in the beginning of October van Vlissingen's letter of 8 August was returned to him.

On 15 October van Vlissingen wrote to Batavia that he intended to reply to Haidar's proposals by informing him that without Batavia's qualification he could not enter into negotiations of suchlike nature,

274 L.f.M., 1780, Moens to Batavia, s.1, January 2, 1780.

275 L. f. M., 1778, I, Proceedings of the Cochin Council, January 20, 1777.

270 L.f. M., 1780, Moens to Batavia, s.l., October 20, 1779. Mem. Moens, p. 70. Rao writes that during 1778 Haidar detached Sardar Khan for the siege of Dharwar (Rao, op. cit., p. 256).

277 L.f. Cor., 1781, I, Van Vlissingen to Batavia, s.l., July 29, 1780.

278 L. f. Cor., 1781, I, Van Vlissingen to The Seventeen, September 4, 1780. 
but that he expected to receive instructions within a few months. He would accompany the letter with some presents in the hope of winning his friendship for the Company and bringing about the release of the prisoners. 279

Van Vlissingen took his time in replying to the proposals. He drafted a letter on 14 November but it was not until the beginning of December that he dispatched Iroelappa with it and with presents to the value of 560 pagodas.

In October, Mysorean troops had also been active near and in Sadras and in villages near Pulicat. By the end of November de Neijs, Dutch resident at Sadras, wrote that he had received a letter from Haidar who demanded that no help, either in the form of victuals or of implements of war, should be given to the British, and further that a capable envoy be sent to him. On 11 December van Vlissingen received a similar letter from the Nawab dated the 9th of November, and a third one arrived from Pulicat. Here a detachment of Lala Chubeela Ram's army had arrived on 20 November and on the next day a couple of letters had been handed over to Tadama, the Dutch resident. Eleven gunshots were being fired by the Mysoreans when the letter of Haidar was opened. In it was stated that Arcot had been captured, that no aid should be given to Madras and that an envoy was to be sent. Tadama had replied in such a polite manner that van Vlissingen later on warned him that it was going too far for a neutral power to express the wish that all Haidar's enemies might be destroyed. On 25 November Lala himself arrived at Pulicat. By treating him respectfully the Dutch could prevent him from looting the town, but they had to acquiesce in the violation of their ancient privileges. The Council at Negapatam approved of the conduct of the servants at Pulicat and qualified them to send a capable native to Haidar with a present to the value of 60 pagodas. A similar qualification had been given to de Neijs at Sadras a fortnight earlier, on 1 December. From several circumstances it became clear that Haidar did not expect a native commissioner from Negapatam but a servant of distinction. For this reason, and because the Danes at Tranquebar already had resolved to send their secretary, the Council at Negapatam decided to send two of its members as commissioners to Haidar to receive his proposals. Moreover, these two

279 L. f. Cor., 1781, I, Van Vlissingen to Batavia, s.1., October 15, 1780. L. f. Cor., 1781, II, Proceedings of the Negapatam Council, September 29, 1780. 
envoys, Simons and Accama, would have to request the release of Topander and the other prisoners. 280

At Batavia van Vlissingen's letters of 29 July and 15 October were discussed by the Governor-General Alting and the Councillors on 20 November 1780 . They decided to send 100 men to Ceylon with instructions for Falck to send them on to Coromandel. The present for Haidar through which it was hoped to procure the release of the prisoners should be a liberal one. Alting had written a report on Haidar's proposal of an alliance in which he rejected this idea, for even if the conditions would have been more reasonable, it would have meant an infringement of the cherished policy of neutrality. He even thought it might perhaps be useful to abandon the possessions in Coromandel temporarily in order to preserve neutrality. The other members of the Council agreed unanimously with Alting's opinion and it was decided to inform Falck and van Vlissingen that they should act on the basis of Batavia's resolutions of 11 January 1779281 with the addition that if it would appear that Negapatam could not be defended successfully the servants in Coromandel should retire to Jaffna. Van Vlissingen was empowered to inform Haidar that the Dutch could not accept his suggestions for an alliance as they wanted to keep strict neutrality. Falck was authorized to advise van Vlissingen in carrying out Batavia's directives and to make dispositions which would serve the Company's interests. ${ }^{282}$

Falck received Batavia's orders - to pursue a policy of strict neutrality - almost simultaneously with a letter from Rosz, the Director at Chinsurah in Bengal, of 28 December 1780. In this letter Rosz informed him that on the 8th of November Warren Hastings had paid him a visit and had spoken about the necessity of finding somewhere assistance for the British. Rosz had advised Hastings to approach Falck with proposals. The result of this discussion had been that Rosz put some proposals on paper on which Hastings made his comment and Rosz his counter-comment. The outcome was a draft-treaty according to which the Company would supply the British with 1,200 European and 1,000 Oriental soldiers in exchange of which the Dutch would obtain full ownership of the province of Tinnevelly and an

280 L. f. Cor., 1781, I, Van Vlissingen to Batavia, s.l., January 27, 1781.

281 See p. 103 supra.

2×2 Secret resolutions Governor-General and Councillors, 1774-81, November 20, 1780. L.f. B., 1781, V, Proceedings High Government, November 20, 1780 ; do., Batavia to van Vlissingen, s.1., November 22, 1780; do., Batavia to Falck, s.l., November 22, 1780. 
exclusive right to the pearl-fisheries. Moreover, they would be allowed to keep the dominions to be conquered northwards of Cochin. It was reported to Falck that the secretary of the Council at Calcutta had left for Madras so as to obtain the ratification of the treaty by Muhammad Ali whereupon it was to be offered to the Company. Falck conferred on these proposals with van Angelbeek, the chief at Tuticorin who had been designated to succeed Moens at Cochin, and their conclusion was that the danger of remaining neutral was certainly not less and perhaps even greater than taking the side of the British. In Falck's opinion Haidar had been the enemy of the Company since he had taken Chetvai and the districts of Paponetty. Now there was an opportunity to stipulate for favourable terms for the Company. He therefore requested Batavia to send him early instructions. Meanwhile he would try to delay as far as possible replying to British requests for help, but if they insisted on a decisive answer he would put the matter before the Council in order to make such dispositions as would seem to give the greatest safety, benefit and profit to the Company. 283

In fact, Falck at that time had already received a request from the English at Madras whose paymaster Light at Palamcottah had written to van Angelbeek at Tuticorin on 17 December 1780 that as the circumstances were so critical for all European nations, the Dutch should take the side of the British. General Coote who had arrived from Calcutta with reinforcements had informed the Council at Madras of proposals which already had been made by the Calcutta Government to Batavia. At Falck's instigation the reply had been that the Dutch had to await the High Government's decision about these proposals. But at the same time Light had been asked what the British and Muhammad Ali were willing to do in return for Dutch aid.284

Although Calcutta, indeed, approached Batavia on the matter this was not done as early as might be concluded from Light's information, for it was only on the 4th of January that Hastings and Wheler addressed a letter to Governor-General de Klerk 285 and the Council. After having pointed out that both the Dutch and the English had been suffering from Haidar's hostilities and that a mutual co-operation to repel his designs was necessary, they went on to say that they had

283 L.f.C., 1781, II, Falck to Batavia, s.l., February 15, 1781; do., Rosz to Falck, December 28, 1780.

284 L. f. C., 1781, I, Falck to The Seventeen, s.1., January 30, 1781. L. f. C., 1781, II, Secret resolutions of the Colombo Council, January 4, 1781.

285 In the letter called Diskerk. As we have seen already Alting was GovernorGeneral at that time. De Klerk had died on 1 September 1780. 
prepared a draft for a treaty of alliance between the English and the Dutch East India Companies and Muhammad Ali. They had first tendered it for approval to Rosz and had obtained his concurrence, after which they had now dispatched it to Madras. As soon as Muhammad Ali consented to the treaty it should be forwarded to Colombo and Cochin for their final ratification. The urgency of the affair made another course of action impossible, and the writers trusted that the High Government would approve of Colombo and Cochin having subscribed to a treaty in which the manifest advantages to the Dutch would free these two governments from every share of responsibility. ${ }^{286}$

Whereas according to the Dutch sources used in the foregoing the initiative to apply for aid lay entirely in British hands, the representation in English sources is different. An exposition of it may be found with Dasgupta. Here the story starts in November 1780 when private information was received at Madras to the effect that the Dutch had made certain offers for an alliance. The nature of the offers was unknown. In the Select Committee Coote gave as his opinion that the situation authorized negotiations with the Dutch and he said he knew that it was a measure which Calcutta very much wished to bring about. Thereupon it was resolved to write to Huddleston, the resident at Nagore, to sound the Dutch at Negapatam, and if he considered the terms advantageous, to inform them that the Bengal Government had already taken steps for an Anglo-Dutch alliance. He should also tell them that Madras was heartily inclined to promote Calcutta's views and explain to them how much it was to their mutual advantage to form an alliance against Haidar. Another letter was written to Light, the source of the original information, asking him for particulars of the Dutch offer and authorizing him to enter into negotiations without, however, committing Madras for the time being. On 22 December 1780 Huddleston replied to Madras and his reply was considered to contain strong arguments against the Dutch proposals. Thereupon Madras put the matter aside for the present. ${ }^{287}$

What did Huddleston reply? That a captain Scott had just arrived and that this person had informed him about the Dutch offers alluded to by Light. Scott told Huddleston that Falck had empowered van Angelbeek to inform Light of his good disposition to assist the English in their present war against Haidar. Falck could not make overtures,

286 L. f. B., 1782, II, Hastings and Wheler to Batavia, January 4, 1781.

287 A. P. Dasgupta, The Central Authority in British India 1774-1784 (Calcutta, 1931), pp. 141-3. 
but if the English should solicit his assistance he would be ready to supply them immediately with 2,000 Europeans and 1,000 Malays. Conditions would be that the British should obtain for the Dutch due reparation for insults and infringements of Dutch rights by Muhammad Ali and that they should mediate between the Company and Muhammad Ali in the outstanding dispute on the pearl-fisheries. ${ }^{288}$

In view of the fact that Madras already felt opposed to these proposals it is not surprising that when Dighton, Hastings's personal envoy, arrived in February 1781 with the treaty drafted at Calcutta, the opposition to that was even stronger. Another point, however, of more immediate importance for this study is how to explain the different impressions the Dutch and the English sources give regarding this matter. When comparing the two the English version seems to contain more peculiar aspects than the other. On 20 November 1780 the Select Committee was informed that in a letter of Light to a Mr Bird the following sentence occurred: "Two days ago I wrote a letter to the Governor, respecting the offer made by the Dutch". This letter never reached its destination.289 Disregarding the lack of restraint with which such matters apparently were being dealt with in private correspondence and with which this correspondence was made available for official use, the next point is that instead of immediately asking elucidation from Light, information was sought in the first place circuitously. On 22 November Huddleston is asked to request particulars from Light and five days later a letter is written direct to Light on the same subject.290

In several respects the treatment of the affair gives the impression that there never was a sincere wish on the side of the Madras Government to attain a concrete result. Is it possible that the whole scheme was launched merely for internal political reasons? For instance, with the aim to make Muhammad Ali more manageable?

However that may have been, Coote's communication at the meeting of the Select Committee that letters had already been written by Cal-

2Ss Madras Select Committec Consultations, range D, no. 5, fols. 18-9. The pearl-fisheries along the Madura coast were an important source of income to the Dutch and therefore also of difficulties with others, especially with Muhammad Ali since he had extended his power southwards (comp. p. 34 supra).

288 Madras Select Committce Consultations, range D, no. 5, fols. 18-9. The

200 Comp. Madras Select Committee Consultations, range D, no. 3, fols. 2039, 2076 and 2088. 
cutta to the Dutch 291 explains Light's wrong intimation with respect to that in his letter to van Angelbeek.

In the Dutch correspondence of the period nothing can be found which indicates that van Angelbeek, indeed, approached Light in the sense as Huddleston wrote. What may have happened, however, is that as a result of Falck's idea of sending Dutch troops to Madura 292 van Angelbeek at some time in 1779 or 1780 sounded Light, and that the suggestion was taken up by Madras at a moment it knew that a similar scheme was being meditated at Calcutta. ${ }^{293}$ Thus, seemingly. the way was made clear for Hastings's policy but the actual results of the way Madras handled the affair were, first that nothing could happen as the Dutch were kept waiting for the British proposals, secondly that pressure was put upon Muhammad Ali, and thirdly that the opponents to the scheme, Muhammad Ali and his clique of British creditors, had plenty of time to organize themselves.

Meanwhile, Haidar's invasion of the Carnatic did not bring any change in the situation near Cranganore as the Mysoreans maintained their power in this region. Moens once more tried to settle the dispute by approaching Sardar Khan, but it was of no avail.294

By then Moens knew that his request to resign his post had been granted and that van Angelbeek had been appointed his successor. Unlike his predecessors Breekpot and Senff he still had an active life in front of him in Batavia where from 1783 to 1789 he held the secondhighest office, that of Director-General.295 During the ten years Moens had been in charge of the Malabar possessions he had given evidence of being a capable administrator. He cannot be denied political insight accompanied with firmness and courage not tending to stubbornness or recklessness, and these qualities served him in his dealings with the

281 Madras Select Committee Consultations, range D, no. 3, fol. 2038.

:92 Comp. pp. 103-4 supra.

293 In January 1780 Falck had expressly authorized Blaaukamer, who for about two years stayed as his commissioner at Muhammad Ali's court in order to negotiate a settlement of the pearl-fisheries dispute, to acquaint the Nawab of Falck's offer of Dutch protection in Madura, but a year later Blaaukamer explained why he had not taken up this suggestion (L. f.C., 1785, III, Blaaukamer to Falck, January 17, 1781). In his reply Falck observed that he knew that already quite early the English at Vizagapatam had been talking about Calcutta's proposals to the Dutch and that probably rumours from Vizagapatam had reached Madras (L.f.C., 1785, III, Falck to Blaaukamer, March 26, 1781).

294 L. f. M., 1781, Moens to Batavia, January 6, 1781.

295 See W. Wijnaendts van Resandt, De Gezaghebbers der Oost-Indische Compagnie op hare Buiten-Comptoiren in Azië, p. 197. 
Mysoreans on the one side and the rulers of Travancore, Cochin and Cranganore on the other. He usually proved himself equal to the occasion and never gave the impression of one who was at his wit's end. It was not his fault that most of his actions were of a defensive nature. They had to be so because the Company in general lacked the strength and the energy to pursue a different policy. On the few occasions 296 that Moens tried to gain the initiative by offensive actions he was unsuccessful, but he deserves praise for the preparations rather than blame for the outcome of these attempts to turn the scales. In both cases his preparation had been thorough and the failures were principally due to the fact that his subordinates who had to execute his designs let him down by failing to rise to the occasion like he himself did so often. Moens was not a great man, but he proved to be a Governor well up to his task and this is more than can be said of many others serving the Company in this period of decline.297

Unlike in Malabar the situation in Coromandel became more and more difficult for the Dutch during the first months of 1781. In February Mysorean troops belonging to Lala Chubeela Ram's army ransacked villages near Negapatam. Van Vlissingen requested damages from Haidar but he was not hopeful about the result of his request. Until then Haidar had neither replied to letters that had been written to him nor had he sent safe-conducts for the envoys. ${ }^{298}$ New trouble arose near Negapatam less than a month later. This time it seemed that the protection which the Dutch for a few months had been giving to several Armenian merchants from Madras and some persons from Tanjore and Trichinopoly was the cause of the Mysorean action. Demands for extradition of these persons were politely rejected and after eight days the troops returned to the main army. Although the situation remained serious, van Vlissingen had hopes that if the worst came to the worst it might be possible to resist Haidar, the more so as general Coote in letters of 25 March and 5 April had hinted at assistance from the English. Meanwhile, however, safe-conducts

296 See pp. $96-7$ and $101-2$ supra.

297 I find it difficult to subscribe to the view of the editor of Moens's Memoir that "he does not appear to have been a man of much cultivation" (A. Galletti in "The Dutch in Malabar", Sel. Dutch Records Madras No. 13 (Madras, 1911), p. 38). Moens's "ignorance of the French language" mentioned in this connection was more than counterbalanced by his genuine interest in sociological and historical questions of which his Memoir gives ample proof.

298 L. f. Cor., 1783, Van Vlissingen to Batavia, s.l., February 26, 1781. 
for the commissioners had arrived and on 17 March, when the Mysoreans were active near the town, it was decided to dispatch the envoys to Haidar's army. Instead of Accama, who was ill, the junior merchant Geeke accompanied Simons, and with their suite they reached the army on $22 \mathrm{March}$. In order to get the prisoners released a present to the value of almost 2,200 pagodas was given along with the envoys, but although Haidar gave them some reason for hope during the first audience on 25 March nothing happened. During a later talk Haidar's ministers demanded 25 lakhs of pagodas without giving any reason why this demand was made. Van Vlissingen thereupon wrote to Haidar that he doubted whether the demand was made on his orders, and asked him to let the envoys know what his proposals were. But Haidar then asked for 5 lakhs of pagodas which the Company should collect from the Armenians and other strangers at Negapatam. Besides, the Dutch should sign a contract which van Vlissingen in his letter to Batavia of 20 April 1781 called absolutely unacceptable. Earlier, Haidar had already been assured more than once that none of the distinguished people he mentioned were resident at Negapatam and this was repeated in a letter of 12 April in which it was added that no strangers were living in that town any more. In fact, some of them had left already and the others were leaving at van Vlissingen's request. It was also stated that it was impossible for the Dutch at Negapatam to sign the treaty he had proposed. At the same time the commissioners were instructed to request another audience in the hope that more reasonable proposals might be put forward. They were qualified to use another 6,000 pagodas for gifts if this seemed necessary to settle the affair and if the release of the prisoners could then be obtained.

Simons and Geeke, however, were unsuccessful in their new attempt to induce Haidar to more reasonable proposals. He insisted on either extradition of the strangers or payment of his demand. Otherwise he would attack Negapatam and keep the envoys prisoner. Van Vlissingen thereupon instructed the envoys to use presents in order to get leave to return. Afterwards he intended to point out to Haidar how unfairly he was treating the Dutch who were observing strict neutrality between him and his enemies. ${ }^{299}$

As was more or less to be expected, van Vlissingen's idea that the envoys might return fairly soon proved wrong. In May 1781 Haidar still demanded a sum of 100,000 pagodas and threatened to set fire to

290 L.f.Cor., 1783, Van Vlissingen to Batavia, s.l., April 20, 1781.

V.K.I. 31 
all the Company's villages and to lay waste Sadras and Pulicat if the Company was not willing to pay. So, eventually the envoys were qualified to offer 100,000 rupees and when this was not accepted, 50,000 more. $^{.300}$

By now, the situation looked rather grim, for who could see the end of Haidar's extortions? Moreover, the impression grew among the Dutch that the Madras Government was entirely opposed to Hastings's proposals of a treaty with the Company, and van Vlissingen agreed with Falck that the British at Madras would like to see the Dutch involved in a war with Haidar, as this would make offers for an alliance from their side unnecessary. ${ }^{301}$

300 L.f.C., 1783, II, Van Vlissingen to Falck, s.1., May 20, 1781.

301 L. f. C., 1783, II, Van Vlissingen to Falck, s.l., May 19, 1781. 
Suddenly the whole situation in Coromandel changed completely for the Dutch when on 13 June 1781 van Vlissingen received a letter of 6 June from Falck informing him that England had declared war upon the Dutch Republic on 20 December 1780. Van Vlissingen immediately instructed Simons and Geeke to acquaint Haidar with this news. The envoys replied that Haidar had expressed his willingness to enter into an alliance with the Dutch against the British provided they promised him immediate assistance. In that case he would protect them with his whole power and give them as many districts as they would like to have. Van Vlissingen and his Council already had arrived at the conclusion that an offensive and defensive alliance with Haidar was most desirable and wrote to him about it on 17 June. By the end of the month the commissioners communicated that before concluding a treaty Haidar wished to know more about the assistance the Dutch would be able to lend. According to them Haidar would like to receive a treaty drafted by the Dutch. Van Vlissingen, thereupon, made a draft and sent it to Falck for comment. Whether the draft was forwarded at the same time to the envoys in Haidar's army is not apparent from the correspondence, but it seems probable. At any rate, van Vlissingen wrote to Falck on 17 August that the envoys had succeeded in concluding an alliance on 29 July. After this agreement had been approved of at Negapatam it was returned to Haidar for ratification. It was probably not until 4 September that van Vlissingen received the ratified treaty, for a copy of that date was sent to Batavia. So although the treaty between Haidar and the Dutch in Coromandel is usually referred to as having been concluded on 4 September 1781 at Negapatam, the conclusion actually took place in Haidar's camp on 29 July 1781.302

In his eagerness to show Haidar that there was no reason to distrust

302 L.f. Cor., 1783, Van Vlissingen to Batavia, s.l., June 21, and September 4, 1781. L. f. C., 1783, II, Van Vlissingen to Falck, s.l., July 8, and August 17, 1781. For the text of the agreement, see Appendix III. 
the Company's intentions van Vlissingen lost sight of all caution. Apart from assisting Haidar at his first request with gunpowder and ammunition the Governor also decided to send auxiliaries to the Mysorean troops in Tanjore. A detachment of almost 600 men under lieutenant Koks left Negapatam on 9 August, a date on which van Vlissingen did not yet know whether the treaty had been ratified by Haidar, whereas the British fleet under Sir Edward Hughes had started its blockade of the town already a month before. The detachment arrived at its destination Shahgota on 22 August. On 5 September the Dutch troops set out together with 3,500 Mysoreans for Mannargudi but three days later it was learnt that this town had been captured by the British. On the 9th the troops returned to Shahgota where on 20 September an order was received from Haidar that the Dutch detachment should return to Negapatam in order to reinforce the town together with some 2,100 men he was going to dispatch. The march home, although along a less direct northern route, took only six days. ${ }^{303}$

While these troops were uselessly wandering about nothing much was done to prepare Negapatam for a siege which was not expected at this time of the year. Till the beginning of September it had only been thought necessary to reinforce the seaside and it was not until the 21st of that month that the Council decided to set up a line of field-works in order to be protected against an attack from the landside as well. Reinforcements sent by Haidar were mainly used for the system of defence outside the town. It seems probable that the Dutch, still somewhat suspicious, preferred to have them there instead of inside the town. The situation remained unchanged until 20 October when news was received that troops under colonel Nixon's command had arrived at Karikal. This detachment forced its way into Nagore 304 on the next day, and the Dutch and Mysorean troops were forced to withdraw to the line of field-works. As soon as Nagore had been captured by Nixon's troops Sir Hector Munro, the general whom the new Governor of Madras Lord Macartney had found willing to join Sir Edward Hughes on the fleet off Negapatam, started the disembarkation of his men. On 22 October the Dutch sent a detachment of

303 L.f.Cor., 1783, Van Vlissingen to Batavia, s.l., September 4, 1781. L.f.B., 1783, IV, Short account of the events at Negapatam since 18 February 1781 by van Vlissingen, Batavia, December 11, 1782; do., Report of Koks to van Vlissingen, September 30, 1781.

304 In March 1781 Mysorean troops had taken possession of this place. According to the 9th article of the agreement between Haidar and the Company Nagore was ceded to the Dutch. 
European and Malay troops to reinforce the line and three days later 1,500 Mysorean horse who had just arrived were sent there also. Nevertheless, the enemy succeeded in taking the whole line in the early hours of 30 October. According to Dutch sources the Mysorean troops took to flight soon after the enemy started its attack, and this made it necessary for the Company's troops to fall back as well. During the following days the British erected batteries against the town. A Dutch sally in the evening of 5 November was unsuccessful. On the 7 th or 8th 305 the British batteries opened fire which was returned by the garrison. After a few days the enemy's cannonade had caused so much damage that the defenders thought a second sally necessary in order to try to silence the most troublesome battery. In the afternoon of the 10 th an ensign set out with 700 Mysoreans to whom had been added some European and Malay soldiers, but they were repulsed. That same night the Council met after van Vlissingen had informed his deputy Mossel that gunpowder sufficient for only one more day was left. The Council thereupon decided to capitulate and the next morning bearers of the flag of truce were sent to the English army with articles of capitulation. After these had been amended they were signed by both parties on 12 November 1781, and on the san:e day the English troops took possession of the town. 306

Whatever little use the Mysorean auxiliaries may have been, their presence proves that Haidar did not let the Company down. Apart from the troops which actually arrived before and during the siege, he even sent some more under Saiyid Sahib who left the main army on 28 October. A few days later the commissioner Geeke received permission from Haidar to join this detachment. On 8 November Kuttur, one day's journey to the west of Negapatam, was reached. Geeke got into touch with van Vlissingen who urged him to attack Nagore. Geeke replied that the detachment had no guns and had been sent to reinforce Negapatam itself. Instead of immediately proceeding to Negapatam

3057 th according to Munro's report, 8th according to van Vlissingen.

306 L. f. B., 1783, I, Van Vlissingen to Batavia, March 8, 1782 (written at Madras). L.f. B., 1783, IV, Short account of the events at Negapatam since 18 February 1781 by van Vlissingen, Batavia. December 11, 1782. M. S. Eng. hist. c. 84, Munro to Macartney, October 26, and 30, 1781. M. S. Eng. hist. c. 85, Munro to Macartney, November 16, 1781. In Munro's letter of 26 October it is stated that he landed at Nagore on the 25th, two hours after Nixon's arrival. From the same manuscript it appears, however, that Nixon indeed had taken Nagore on the 21st (Macartney to Munro, October $29,1781)$. Otherwise there are no important discrepancies in these Dutch and English sources dealing with the siege of Negapatam. 
Saiyid Sahib decided to wait for reinforcements from Tanjore. These arrived on the 10th and the detachment was about to strike camp when it was suddenly attacked by British troops dispatched by Munro. The Mysoreans had to retreat and Geeke's hope to arrive that night at Negapatam vanished into thin air. Saiyid Sahib sent for more horse who arrived the next day, and after having proceeded along a heavy road his troops came within an hour's distance of the town on 13 November. Villagers then told the Mysoreans that Negapatam had surrendered the day before. The Mysorean officers immediately started to talk about treason and for the first days afterwards Geeke was kept under surveillance, but subsequently he received permission to return to the main army. 307

An inquiry into the causes of Negapatam's surrender set up on orders of the High Government later on failed to furnish a clear proof of treason, but that several Dutchmen had behaved badly is an established fact. Among them van Vlissingen ranks first. Several reports point to the fact that he pretended to be ill during most of the last week of the siege. Moreover, the active part that he played in some of the most baffling events is quite remarkable, so say the least. First, it was van Vlissingen who suddenly knew that insufficient gunpowder was left. Furthermore, he wrote a second letter to Geeke in the afternoon of 9 November, in which he insisted on an attack on Nagore that night although he knew by then from Geeke's letter to him that the detachment was not equipped for this task. The Mysoreans should indicate their attack by the firing of three rockets, at which signal part of the garrison was to make a sally. According to what some escaped prisoners-of-war told Geeke afterwards a detachment had been ready in the town to sally at the signal of three rockets, but when they were fired the Mysorean officers refused to march out saying that these were no rockets of Haidar's. ${ }^{308}$ The committee of inquiry, under the chairmanship of Falck, held it proved that the sudden lack of gunpowder was the result of someone having tampered with it. The committee also stressed the point that the Council-members had shown reluctance in their co-operation with Haidar whose advice they had flouted. They had become more and more cool and indifferent towards Haidar and finally roused his anger by their behaviour to his resident sent to Negapatam in compliance with the 6th article of the agreement. Haidar also strongly protested with the commissioners in his army

307 L. f. M., 1784, I, Geeke to van Angelbeek, January 15, 1782.

308 Loc. cit. 
about the way the commanders of his troops and the troops themselves had been treated by the Council at Negapatam. ${ }^{309}$

On the other hand, Saiyid Sahib's expedition cannot be said to have been properly carried out either. Too much time was wasted and the vigilance was not in accordance with the circumstances. But this is only of secondary importance and the coward behaviour of van Vlissingen and other members of the Council must be held responsible for the surrender of the town at a moment when assistance and the rainy season were not far off. The whole enterprise must be considered a great personal success for Lord Macartney who right from the beginning had been zealous for it against the advice of several of the military leaders. ${ }^{310}$ Its fulfilment meant that the Dutch had lost the last of their possessions in Coromandel and that, in Innes Munro's words, a very important key to the Tanjore country and other southern provinces had been put into British hands. ${ }^{311}$

When van Angelbeek at Cochin received news of the war with England, he kept this information secret for some time at the request of the chief at Tuticorin who had forwarded Falck's letter about this matter to him. This chief's aim was to be the better able to guard the interests of the factories which were under his supervision. It was, therefore, not until 19 July 1781 when rumours about war began to spread that van Angelbeek informed the other members of the Council. It was then decided that an attempt should be made to settle the dispute with Haidar and to get assistance from the rulers of Cochin and Travancore. Consequently, commissioners were sent to Rama-Varma in order to inform him that the Dutch were making peace with Haidar, and that they were willing to draw him into the negotiations provided he remained on their side or, at least, strictly neutral. Rama-Varma replied that he was an ally of Muhammad Ali and the British and that as they were at war with Haidar he would have nothing to do with

300 L.f.C., 1785, I, Secret resolutions of the Secret Council at Colombo, December 27, 1783. This special Council consisting of some senior members of the ordinary Council, had been set up by Falck in 1781 in order to deal with war affairs.

310 Sir Eyre Coote (comp. Innes Munro, $A$ Narrative of the Military Operations on the Coromandel Coast, against the combined forces of the French, Dutch, and Hyder Ally Cawn, from the year 1780 to the peace in 1784; In A Series of letters (London, 1789), p. 252; C. Collin Davies, ed. of The Private Correspondence of Lord Macartney (London, 1950), p. 169) and Braithwaite (comp. M. S. Eng. hist. c. 84, Braithwaite to Macartney, October 1, and 4, 1781).

311 Innes Munro, op. cit., p. 258. 
the Mysorean ruler. He also warned the commissioners that if the Dutch were to join in with Haidar he would feel compelled to oppose them.

The negotiations which van Angelbeek subsequently started with Sardar Khan were apprehensively watched by Rama-Varma who became especially suspicious when false rumours were spread that the Company wanted to cede Cranganore to the Mysoreans. Van Angelbeek put this right in a letter to the raja. ${ }^{312} \mathrm{He}$ did not disguise from himself that Rama-Varma could not be trusted, and that in case the English should attack Cochin he would assist them, either openly or secretly. In van Angelbeek's view the situation was rather awkward. for the real interest of the Company demanded that Rama-Varma should not expose himself to usurpation by Mysore, but the raja was averse to the Dutch idea of preventing this by drawing him into their negotiations with Sardar Khan. Van Angelbeek, therefore, did not quite know how to tackle these negotiations. ${ }^{313}$ Falck, to whom he put his problem, advised him to conclude a treaty with Sardar Khan in which only the common enemy and those who were siding with him should be mentioned. Probably the Mysoreans would merely ask for assistance in taking Tellicherry whereas they would promise to help Cochin in case of a British attack. An agreement of short duration on this basis would be acceptable to the Dutch who at the same time should press Rama-Varma hard so that he would abstain from assisting the enemy. In Falck's opinion it was highly improbable that the war was going to last long and after that it might be necessary to pursue a completely different policy. ${ }^{314}$ Somewhat later, however, Falck partly changed his view when he expressed his hope that meanwhile van Angelbeek would have concluded a treaty with Sardar Khan and strongly advised him to induce Rama-Varma to make an advantageous contract with the Mysoreans as well. Falck at the same time informed van Angelbeek that Batavia had instructed him to assist Cochin and Negapatam with his advice. ${ }^{315}$

At Batavia the first report about the war in Europe had been received on 10 June 1781, but it was not until 6 July when a second report came in that the High Government proceeded to action! It was then considered that in the first place an alliance should be concluded

\footnotetext{
312 L.f.M., 1783, II, Van Angelbeek to Batavia, s.l., November 24, 1781.

L. f. M., 1783, I, Secret resolutions of the Cochin Council, July 19, 1781.

313 L. f. C., 1783, II, Van Angelbeek to Falck, s.l., September 4, 1781.

31.4 L. f. C., 1783, II, Falck to van Angelbeek, s.1., September 27, 1781.

315 L. f. C., 1783, II, Falck to van Angelbeek, s.l., November 11, 1781.
} 
with the French while among possible native allies Haidar ranked first. It was felt that his hostile treatment of the Company, at least as far as Coromandel was concerned, had to be attributed to a large extent to the policy of strict neutrality, and to the fact that occasionally facilities had been given to the British whereas his requests had been declined constantly. Although an alliance with Haidar might have serious consequences in the future, the Council considered that averting the present danger should prevail over fear of a future risk. Consequently, a resolution was passed to empower Falck to conclude an alliance with Haidar provided the Nawab was willing to enter into an agreement on reasonable conditions. At the same time van Vlissingen should be qualified to make some proposals in this respect to Haidar. In case of need the Governor at Negapatam was allowed to agree upon some preliminary articles with Haidar, but this should only be provisional, and the making of a formal treaty should be left to Falck. In the same way van Angelbeek was to correspond with Falck about an agreement with Haidar as far as Malabar was concerned. On an arrangement with Travancore by which the Company's security would be best served van Angelbeek should also consult Falck. Moreover, the latter was commissioned to conclude an alliance with the French, 316

The hope which Falck had expressed in his letter of 11 November 1781 that van Angelbeek already might have concluded an agreement with Sardar Khan proved to be false. Nevertheless, van Angelbeek was satisfied about the state of affairs, for the Mysorean had promised assistance against the common enemy. The old dispute about Chetvai, Paponetty and the "Sandy land" had not been settled but van Angelbeek did not want to press this matter at a moment when Dutch prestige was so low as a result of the fall of Negapatam. Moreover, Sardar Khan's whole way of acting clearly indicated that Haidar still intended to attack Travancore and wished to prepare the way through an alliance with the Company. Van Angelbeek was, therefore, in no hurry to enter into a formal treaty and contented himself with the Mysorean professions of friendship and promises of aid, whereas he, on his part, showed his good will by supplying Sardar Khan with munitions. ${ }^{317}$

316 Secret resolutions Governor-General and Councillors, 1774-81, July 6, 1781.

317 L. f. M., 1783, II, Van Angelbeek to Falck, s.l., December 30, 1781; do., Van Angelbeek to Batavia, s.1., January 22, 1782; do.. Van Angelbeek to Sardar Khan, December 21, 1781. 
In December 1781 yet another problem invited the attention of the servants at Cochin. As we have seen before, 318 the Council at Negapatam had dispatched commissioners to Haidar in March 1781. In accordance with article 6 of the treaty with Haidar the Council appointed on 4 September next the sworn clerk Hasz resident with the Nawab. Hasz arrived in Haidar's army by the end of October. His arrival concluded the task of the commissioners but Haidar was unwilling to give them permission to leave. After Negapatam's fall the commissioners and Hasz applied to van Angelbeek for directives and for money to cover their expenses. The Council at Cochin dealing with the matter on 26 December was of opinion that the commissions had ended at the moment the Negapatam Government had ceased to exist. It was, therefore, decided to advise the commissioners and the resident to bring this to Haidar's notice and to request his assistance in order to leave for Cochin or Colombo. 319

It soon became clear, however, that Haidar took a different view and Simons and Geeke arrived at the conclusion that their only chance of getting away was that van Angelbeek under some pretext should request Haidar to dismiss them. After they had left it would be easier, they thought, to get Hasz's release. When Hasz found out about this suggestion he protested, for he did not at all like the idea of being sacrificed to Haidar's vindictiveness in case the treaty should not be fulfilled properly. 320

Van Angelbeek forwarded the letters from the commissioners and Hasz to Falck who advised them to try to obtain permission for a journey to Tranquebar. It remains to be seen, however, whether this advice had anything to do with the fact that on 9 March 1782 Haidar dispatched Geeke with a letter to Falck. In it he stated that he was surprised that no Dutch ships had arrived together with the French fleet.321 If Dutch ships with munitions were sent soon he would retake 318 P. 113 supra.

319 L.f.B., 1783, IV, Short account of the events at Negapatam since 18 February 1781 by van Vlissingen, Batavia, December 11, 1782. L. f. M., 1783, I, Proceedings of the Cochin Council, December 26, 1781. L. f. M., 1783, II, Sinous and Hasz to van Angelteck, November 26, 1781; do.. Simons and Geeke to van Angelbeek, December 5, 1781; do., Hasz to van Angelbeek, December 6, 1781.

320 L.f. M., 1784, I, Simons and Geeke to van Angelbeek, January 15, 1782 ; do., Hasz to van Angelbeek, January 22, 1782.

321 Admiral Suffren's squadron had sailed from Brest in March 1781 and had reached Indian waters in the beginning of 1782 (see G. B. Malleson, Final French Struggles in India and on the Indian Scas (London, 1884), pp. 11 and 19). 
Negapatam and the other lost places and return them to the Company. Falck replied that the war in European waters explained why the ships and troops had not yet arrived although they had been promised in letters received from Holland. Availing himself of the fact that Geeke had been released Falck decided to appoint him agent 322 on the Coromandel coast, and sent him to Tranquebar where he should reside until he could take possession of Negapatam. For this purpose he was instructed to enlist two companies of sepoys. Falck informed Haidar of this step and at the same time hinted that he would appreciate Simons's being allowed to go to Tranquebar as well. ${ }^{323}$

Haidar took up this idea and in June Simons obtained permission to leave for Tranquebar. Haidar instructed him, however, that after he had enlisted soldiers he should join Mir Moin-ud-din's 324 army in Tanjore in order to take Negapatam. Simons took along a letter from Haidar addressed to the Governor-General in which he was asked to send 10,000 Malay and European soldiers. ${ }^{325}$

Falck was only too glad that at least the expensive stay of the two commissioners in Haidar's army had now come to an end. He, therefore, thought out a way to prevent Simons from returning there by summoning him from Tranquebar to Colombo and justified it with Haidar by informing him that complaints about Simons's behaviour towards the Nawab had reached him. This was true, for Hasz had reported in this sense, but we can be pretty sure that otherwise Falck would have thought of some other excuse to keep Simons under his own authority. Falck added that a letter and presents from the Governor-General would reach Haidar via Tranquebar and that some time ago Dutch ships had indeed put out, but that as a result of all sorts

322 Earlier the Council at Colombo had already decided to send Ebell, resident at Punto Pedro, as its agent to Tranquebar (L.f.C., 1783, II, Falck to Batavia, s.l., February 12, 1782). This neutral Danish possession served as an observation-post for the belligerents.

323 L.f.C., 1783, I, Falck to Simons and Geeke, February 22, 1782; do., Falck to Simons, Geeke and Hasz, May 1, 1782 (the mentioning of Geeke in the address seems wrong as Falck knew by then that he had left); do., Falck to Batavia, s.l., May 12, 1782. L.f.C., 1784, II, Haidar to Falck, February 27, 1782; do., Falck to Haidar, April 30, 1782. L.f. M., 1783, I, Simons to van Angelbeek, March 16, 1782.

324 This is the same person as Saiyid Sahib (comp. C. Hayavadana Rao, History of Mysore, III, p. 575).

325 L. f. C., 1784, II, Haidar to Falck, June 4, and July 27, 1782. L. f. C., 1783, I. Simons, Geeke and Ebell to Falck, July 10, 1782. 
of adversities they had been forced to return to Dutch harbours. But now he expected them very soon. ${ }^{326}$

The explanation why the Dutch fleet had failed to come was given by Falck because earlier in the year Geeke and Ebell had assured the Nawab that the ships had sailed in September 1781. Falck took them to task for communicating this on insufficient grounds. He was generally far from satisfied about the behaviour of his agents at Tranquebar. From different sides complaints were made about the way they treated Haidar and his representatives in their correspondence and personal contacts. Moreover, there were serious differences of opinion among the agents themselves. ${ }^{327}$

The fact that so far Dutch ships had failed to arrive caused great anxiety both at Colombo and at Batavia. In a letter of 12 February 1782 Falck already pointed out to the Secret Committee for War Affairs, which had been set up by The Seventeen, that the heavy losses in the west - those of the factories of Surat, Bengal, and Coromandel as well as Trincomalee - were all due to the fact that no assistance had arrived either from Holland or from the French for such a long time. ${ }^{328}$ This certainly is an exaggeration, for it is difficult to see how even if reinforcements had arrived in time the factories of Surat and Bengal could have been retained in Dutch hands. Besides, at about the same time Falck admitted in another letter that the main cause for the loss of Trincomalee had been the incompleteness of the fortifications on the landside. ${ }^{329}$ But Falck's statement shows that already at that time he felt disappointed about the lack of assistance from home. The same disappointment existed at Batavia where the High Government stated that it had learnt with regret from letters of the Secret Committee of 23 August and 28 September 1781 that the planned sailing of a fleet had been postponed. Lack of man-power had first caused the original number of fourteen men-of-war and freighters to

320 L.f.C., 1783, I, Falck to Geeke and Ebell, September 5, 1782; do., Falck to Batavia, November 11, 1782. L. f. C., 1784, II, Falck to Haidar, September 5, 1782.

327 L. f. C., 1783, I, Falck to Geeke and Ebell, July 4, and September 5, 1782; do., Geeke to Falck, August 23, 1782. Falck's rebuke concerning the communication of the sailing of the ships does not seem fair in view of his own advice given in November 1781 to van Vlissingen, viz. to assure Haidar that French and Dutch fleets were to be expected within a few days ( $L$. f.C., 1783, II, Falck to van Vlissingen, s.l., November 1, 1781).

328 L.f. C., 1782, Falck to the Secret Committee for War Affairs, February 12, 1782.

320 L. f. C., 1783, I, Falck to Simons and Geeke, February 22, 1782. 
be reduced to nine, then different circumstances had led to delay in the execution of the expedition and finally weather conditions had made it altogether impossible. 330

For a better understanding of the maritime position of the Company in these years it may be useful to remember that the original policy of having a regular navy, often in the form of permanent squadrons, had been abandoned long ago. In the 18th century the decay of the Company's navy followed closely on that of the navy of the Dutch Republic. A smaller number of ships, which moreover were of an inferior quality, were built and the losses at sea increased. The captains of the return-ships from which sometimes squadrons were formed were more keen on bringing their freight safely home than on taking part in aggressive operations. Generally the standard of officers and crew was lower than in the 17 th century. ${ }^{331}$

Soon after the war broke out the Company applied to the States General for assistance, mainly in order to protect Java, but its request was turned down because the navy of the Republic itself was in such a bad state.332 As Bartstra puts it, "when war broke out in 1780, the Republic hardly possessed any ships at all". Internal dissensions about the question whether the land forces or the naval contingents or both should be strengthened had not failed of their crippling effect. ${ }^{333}$ After the fall of Trincomalee the Company approached the Stadtholder who after serious consideration agreed to the request to send a squadron for the purpose of reconquering the lost possessions in collaboration with the French fleet. By the end of 1782 the Dutch Government and the Company had reached complete agreement on the matter, but the discussions with the French did not proceed smoothly, and so it was not until March 1783, that is to say after an armistice with Britain had been agreed upon, that the squadron of the Republic under command of van Braam actually sailed. As a result of the changed situation its task became to assist the Company in restoring its seriously undermined prestige in the Archipelago. ${ }^{334}$

330 L.f.B., 1782, VII, Batavia to the Secret Committee for War Affairs, August 22, 1782.

331 T. H. Milo, De invloed van de zeemacht op de geschiedenis der Vereenigde Oost-Indische Compagnie (den Haag, 1946), pp. $14-6$.

sis2 W. Voorbeytel Cannenburg, „De eerste expeditie van 's Lands zeemacht naar Oost-Indië", Jaarverslag Vereeniging Nederlandsch Historisch Scheepvaart Museum, IX (Amsterdam, 1925), Bijl. D., p. 95.

333 J. S. Bartstra, Vlootherstel en legerangmentatie 1770-1780 (Assen, 1952), p. 280.

334 Voorbeytel Cannenburg, op. cit., pp. 95, 99-100, 103. 
It is not surprising that with naval strength being at such a low ebb both Falck and the High Government could only reply to Haidar's repeated requests for ships by making excuses for the present and expressing hopes for the future. The first request had been made when Negapatam was still in Dutch hands. A letter to that effect accompanying some gifts from Haidar was forwarded by van Vlissingen to Alting, the Governor-General. Whereas the presents reached Batavia via Ceylon in January 1782, the letter which had been given along with a Danish vessel to Malacca did not arrive till 13 September of the same year. When the letter had not yet arrived in June the High Government decided not to wait any longer before amply recompensing the presents. Gifts worth 5,816 guilders were sent to Ceylon with a covering letter in which Haidar was thanked for the presents. ${ }^{335}$

Batavia's letter to Haidar of 17 June 1782 was forwarded by Falck to Tranquebar in October with instructions for Geeke and Ebell to have it delivered together with the presents when occasion arose. In November two letters of 27 July and 26 September arrived at Colombo in which Haidar complained about the fact that Geeke and Simons stayed at Tranquebar without enlisting the 5,000 men needed for the reconquest of Negapatam. Falck, however, had been of opinion that it would not be advisable to increase the number of some 760 sepoys who had been enlisted because the Company could not provide for more. Otherwise, it would have been quite easy to increase the number, for the scarcity of food made people eager to take service. ${ }^{336}$

Meanwhile, the situation of the Dutch in Malabar had suddenly deteriorated when the British at Tellicherry, who had been besieger for over a year, sallied out in January 1782 and routed the Mysorean army of Sardar Khan who was taken prisoner. On hearing this news the Council at Cochin resolved to abandon Cranganore and Ayacottah if the enemy should proceed southwards. Soon afterwards the English took Calicut and the Mysoreans evacuated Chetvai and Paponetty. When, however, it was noticed at Cochin that British troops had not taken part in the occupation of these places and, moreover, it was learnt that Mysorean reinforcements had arrived at Palghat, the Council decided not to abandon Cranganore and Ayacottah for the time being.

335 L.f. Cor., 1783, Van Vlissingen to Batavia, s.l., September 4, 1781. L.f.B., 1782, VII, Batavia to the Secret Committee for War Affairs, June 18, 1782. L.f. B., 1783, I, Batavia to Haidar, June 17, and September 24, 1782.

${ }_{336}$ L. f. C., 1783, I, Falck to Geeke and Ebell, October 3, 1782; do., Falck to Batavia, s.l., November 11, 1782. L. f. C., 1784, II, Haidar to Falck, July 27, and September 26, 1782. 
Against an Indian enemy the defence was not only thought possible, but even essential. There were strong indications that the British intended to disembark European forces to the south of Cochin, while Indian troops were to advance from the north. In that case van Angelbeek wished to be able to detain the troops from the north as long as possible. The fact that an attack against Cochin was being planned was deduced among other things from Rama-Varma's behaviour. Large stocks of victuals were collected in Travancore and the Paljetter's troops who had been encamped at Ayacottah together with Company forces secretly went off without any warning. But the plans were not carried into effect and rice was transported inland again, whereas a large number of livestock was offered for sale on the market of Cochin. Why the British changed their plans van Angelbeek could not say. As possible explanations he thought of the reinforcement of Cranganore and Ayacottah and of the information that a Mysorean army was approaching. ${ }^{337}$ Of course, he did not know that John Sulivan, political resident at Tanjore, had expressed Macartney's views on the line of action to be pursued in the following words to colonel Humberstone and captain Smith, who at that time were in command of the forces in the west:

"... I write in the confidence that you will not be directed from the first object of the present war by any attempt upon Cochin or Colombo - both places will fall of necessity when Haidar is reduced, and neither can send him succour; on the contrary the care of them will prevent him from receiving any effectual aid from the French $-\ldots . " 338$

Nevertheless, the tension at Cochin increased again by the end of March when it seemed that the enemy made new preparations for a siege. Once again Rama-Varma lent his assistance. Van Angelbeek afterwards was convinced that Humberstone could have increased the number of his men by adding Nairs and Moplahs, but it seemed that the resident at Tellicherry, who had been asked for his assistance, had refused to have anything to do with this plan as long as he had not

337 L.f. M., 1783, I, Van Angelbeek to Batavia, s.l., May 2, 1782; do., Secret resolutions of the Cochin Council, January 22, February 18, and 19, 1782.

338 M. S. Eng. hist. c. 86, Sulivan to Humberstone and Smith, February 23, 1782. For Sulivan's behaviour in this matter comp. M. Wilks, Historical Sketches of the South of India, II, pp. 380-2. 
received special orders from Bombay. In any case the plan was again given up for the present. 339

Van Angelbeek now expected that the enemy would advance in September or October and when he informed Haidar in May that five English ships had sailed southwards from Calicut, probably for the purpose of strengthening Hughes's fleet, he used this opportunity to stress the necessity of resisting the enemy in the west. During the same month he had a conference with the Dellawa who admitted that his master, Rama-Varma, for fear of the British and Muhammad Ali had deviated from neutrality. Pledges for a neutral policy in future were given but it soon became evident that Travancore did not live up to them. In June the English made preparations at Chetvai from which the Dutch gathered that an attack on Cranganore and Ayacottah was being planned. Travancore delivered a large amount of gunpowder at Chetvai and it seemed that Rama-Varma was more than ever convinced that his country would not be safe from Haidar until the British had taken Cranganore and Cochin. He, therefore, urged Humberstone to capture these towns and also tried to persuade the raja of Cochin to take the side of the British against the Company, but this ruler firmly declined Travancore's suggestion. Van Angelbeek received information, however, that Humberstone had replied to Travancore that Palghat should first be taken in order to prevent the Mysoreans from disturbing them while besieging Cochin. The British were willing to carry out these plans if Rama-Varma would provision and pay their troops during two months and join them with 4,000 men of his own.

Van Angelbeek, on the other hand, received in July a proposal from the commander of Haidar's troops to advance together against the British at Calicut for which purpose the Company should send 4,000 soldiers to his army. Van Angelbeek politely declined this by pointing out that at present he could spare only a few men. In the autumn,

330 L. f. M., 1783, I, Van Angelbeek to the Secret Committee for War Affairs, May 1, 1782; do., Van Angelbeek to Batavia, s.1., May 2, 1782. A letter of Sulivan makes it clear that in March 1782 Humberstone indeed proposed to Bombay to attack either Mangalore or Cochin (M. S. Eng. hist. c. 87, Sulivan to Macartney, March 31, 1782). Bombay did not approve of the proposal but the reply did not reach Humberstone soon. He therefore made preparations to besiege Cochin whereupon Bombay took steps to assist him (Bombay Abstract Letters Received, 3, 1767-83, Bombay to the Court of Directors, April 25, 1782). It seems, however, that the conflicting views among the English and the fact that Mysoreans were still active in the neighbourhood (comp. J. Le Couteur, Letters from India (London, 1790), p. 105) explain why the plan was eventually given up. 
however, he might be stronger if reinforcements from Europe should arrive.

The plan of an attack on Cranganore literally went up in smoke when on 1 August the stronghold of Chetvai was blown up. By the end of August van Angelbeek received a letter of 22 June from Haidar in reply to his letter of early May in which the Nawab stated that he had already sent troops to the west and that more were to follow soon. In his answer of 10 September van Angelbeek intimated that it would be in the common interest if the outstanding disputes could be settled.

Talks between the British and Travancore about a combined expedition against Palghat led to an agreement and part of the 4,000 Travancorean troops gathered near Cranganore. The Dellawa wished to march with them to the English army along the shortest way in which case he would have to pass the fort of Cranganore. But the Company refused to permit this and the troops had to make a detour through the northeastern districts of Travancore in order to be able to join the English. In September the forces set out for Palghat 340 but in November they withdrew to the coast. In the middle of November Tipu arrived with an army at Palghat and subsequently followed the enemy to the coast where he advanced in vain against the entrenchments near Ponnani. Somewhat earlier the British were reinforced by the disembarkation of colonel MacLeod with 400 European soldiers who had been sent oversea from Madras. Van Angelbeek informed Tipu of their arrival and received a letter of thanks for this communication.

Shortly afterwards, on 8 December, Tipu wrote again instructing van Angelbeek to forward a letter meant for de Suffren to Ceylon for further delivery to the French admiral. This letter stated that the French fleet should sail to the Malabar coast so as to invest the British at Ponnani from the seaside as well. Tipu further requested van Angelbeek to keep him informed about all events taking place, especially about the actions of Travancore. The French commander Lallee had added a letter in which he advised van Angelbeek to send a few European officers to compliment Tipu. Van Angelbeek had the impression that this had been written with Tipu's knowledge and he, therefore, thought it better not to postpone sending commissioners. Three officers were designated for the task and gifts were prepared, among which two cases with medicines and bandages of which the

340 According to Le Couteur, who was with the English troops, they stayed for a short while at Ponnani in order to keep Haidar and the Dutch equally in doubt with respect to their future intentions (Le Couteur, op. cit., p. 128).

V.K.I. 31 
army was short. Van Angelbeek wrote a letter to Tipu on 15 December in which he stated that Rama-Varma had indeed sent some troops for fear of the British, but that he would promptly change sides the moment he noticed that the Dutch could liberate him from English domination. However, while a ship was fitted out to convey Tipu's letter to Ceylon and the commissioners prepared themselves for their journey to the Mysorean army, news arrived on 17 December that in the morning of the 13th Tipu had broken his camp at Ponnani and had withdrawn to Palghat. ${ }^{341}$

It took some time until the reason of Tipu's sudden retreat became known at Cochin. By then, the Dutch agents at Tranquebar had already been able to report the death of Haidar to Colombo, thanks to information given by Hasz. On 22 November Hasz wrote to Falck that Haidar was suffering from a tumour on the spine. It was said to be the size of a dinner plate and to be very painful for the patient who did not want to eat. At first an Armenian and a Muslim physician had treated the Nawab but recently French doctors had been called in. Hasz had been informed secretly that the illness might prove fatal. In a postscript to his letter he added that he had just been told that a courier had been dispatched to Malabar with a message for Tipu that he should come over with a small suite. ${ }^{342}$ On 7 December Hasz sent a letter from near Chittur to inform Falck that Haidar had died that morning between 9.30 and 10.00 a.m. His death was kept very secret and immediately a camel-rider had been dispatched to Tipu. ${ }^{343}$ The agents at Tranquebar, furthermore, reported to Falck that after Haidar had been operated upon he had developed dysentery. When he sensed that his death was near he had summoned Piveron de Morlat, the French resident, and had reproached him in a most terrible way with the behaviour of the French. He had commissioned his younger son Karim Sahib to take the command of the army until Tipu's arrival, and Karim Sahib kept the army moving continually. ${ }^{344}$

From these letters it is clear, that whatever the degree of correctness of the news concerning the course of Haidar's illness and the measures in connection with it, Hasz was not sent for during this period. And

341 L.f. M., 1783, I, Van Angelbeek to Batavia, s.l. May 2, and 5, 1782; do., Van Angelbeek to the Secret Committee for War Affairs, March 17, 1783. L. f. M., 1784, I, Van Angelbeek to Batavia, s.l., March 31, 1783.

342 L. f. C., 1783, I, Geeke and Ebell to Falck, December 16, 1782. L.f.C., 1784, I, Hasz to Falck, November 22, 1782.

34 L. f. C., 1784, I, Hasz to Falck, December 7, 1782.

2.4 L. f. C., 1783, I, Geeke and Ebell to Falck, December 17, 1782. 
so the last time he met Haidar may have been on 29 September when Haidar told him that he did not know what to think of the western nations. For, reports had reached him that the British were to besiege Cochin and that the Cochin authorities were in correspondence with them in order to capitulate without offering any resistance. In another respect the audience was not very pleasant either. About the middle of September six men who had been serving with the Company at Negapatam and Trincomalee and had escaped from Madras were seized by Mysorean horse. Haidar wanted them to take service with him. When they refused they were put into chains and threatened with transportation to Seringapatam. Hasz now only managed to get their release on condition that they took service with the Mysorean army.345

As soon as Tipu reached the army near Arcot on 29 December Hasz sought audience of him. Although he was not received as early as Piveron Hasz's first audience already took place in the evening of 1 January 1783. A gift of 350 rupees to the prime minister Krishna Rao and Abu Muhammad Mirdah, who together held a firm grip on the army, had contributed to this result. Hasz congratulated Tipu and recommended the Company's interests to his favour. Tipu replied that he would do everything to please the Dutch. ${ }^{346}$ Hasz took this initiative long before he received official instructions to compliment the new ruler. These were given by Falck in a letter to his agents at Tranquebar, who should forward them to Hasz, who was also asked to state Tipu's name and titles which undoubtedly would have been changed the moment he came to the throne. The letter and presents from the Governor-General to Haidar should, if they had not yet been dispatched from Tranquebar, be offered to Tipu. ${ }^{347}$

In spite of the information about the events in the Mysorean army with which Hasz provided him Falck did not think that his stay there was of much use to the Company. At any rate the costs were far too high, and in November 1782 Falck let Hasz know that henceforth he would have to make both ends meet with 200 pagodas a month, and 50 for the interpreter. Hasz replied that this sum was not even sufficient for the payment of the 55 coolies who were in his service and who were absolutely indispensable as bearers of his palanquin, cases, furniture, six tents etc. Moreover, he was also employing seven servants for ceremonial reasons and nine others, among whom one to chase off

345 L.f.C., 1784, I, Hasz to Falck, October 8, 1782.

346 L. f. C., 1784, I, Hasz to Falck, January 2, 1783.

347 L. f. C., 1783, I, Falck to Geeke and Ebell, December 31, 1782. 
flies, a dhobi, a barber, a cook and a leader of the coolies, for more personal services. Then there was a guard of 12 sepoys with a sergeant and two corporals as well as three letter-carriers. Finally, he had to pay one rupee daily as batta $\mathbf{3 4 8}$ to each of three officials placed at his disposal by Haidar. The real duty of these officials attached to influential persons was to report daily to the Nawab about their doings. His mess-allowance of 60 pagodas a month was so little, Hasz said, that he never dared to invite the French resident in return. ${ }^{349}$ Falck, however, was not impressed by Hasz's exposition and replied that from February onwards he would not be allowed to spend more than 200 pagodas. If he contented himself with one tent and two or three peons instead of all the useless servants this amount would be ample. Falck assured him that he would take the consequences of the reduction in ceremonial for his account. He added that he did not see any useful purpose in his commission and, therefore, advised him to seek a suitable excuse to get permission from Tipu to go to Tranquebar. ${ }^{350}$

Hasz probably thinking that under the new arrangement his further stay would not be sufficiently lucrative had already, before Falck wrote his letter, reported in March that he had vainly requested Tipu to allow him to go to Tranquebar. At the same time he informed Falck that the peace-negotiations between Tipu and the British, on which he had reported the month before, had fallen through, as was said because the English demanded a considerable sum of money.351 By the end of May, however, Hasz received permission to go to Cuddalore on account of illness. He arrived at this French base shortly before it was besieged by the British. Although hostilities stopped soon afterwards Hasz did not see his way to proceed to Tranquebar until October. ${ }^{352}$ It was only then that the representation of the Company in the Mysorean army came to an end, a representation which had cost enormous sums of money and had yielded no profit whatsoever.

In the beginning of 1783 Falck had also to comment upon a financial matter of quite a different nature. The Company had agreed to pay

\footnotetext{
343 Means an allowance for daily expenses. Originally it was an extra allowance made to officers, soldiers, or other public servants. when in the field, or on other special grounds (H. Yule and A. C. Burnell, Hobson-Jobson (new ed. by W. Crooke, London, 1903), p. 72).

349 L.f. C., 1784, I, Hasz to Falck, January 28, 1783.

350) L. f. (., 1784, II, Falck to Hasz, April 5, 1783.

351 L.f. C., 1784, I, Hasz to Falck, February 25, and March 7, 1783. For the negotiations comp. Rao, op. cit., p. 643.

352 L. f. C., 1785, II, Hasz to Falck, July 10, and October 11, 1783.
} 
the French $2 \frac{1}{2}$ million guilders for their war-expenses, and in the autumn of 1782 the High Government realized that it would not be able to send part of this sum in time to Colombo. It therefore suggested that Falck should try to obtain a loan from Haidar. It was felt that it would be rather strange to put this to Haidar who had received only promises of future assistance in reply to his requests for ships and troops, but, on the other hand, his interest in French aid was considered so great that for this reason he might agree to the idea. ${ }^{353}$ Falck, however, seeing things more in their true perspective, rejected the plan, arguing that Haidar himself was having such large war-expenses that he could not be expected to lend money to the Dutch on behalf of the French neither of whom had given him much assistance so far. ${ }^{354}$

When van Angelbeek at Cochin learned the reason of Tipu's sudden departure from Ponnani he feared serious consequences as a result of Haidar's death, particularly in the form of insurrections in the countries occupied by the Mysoreans. The general position of the Dutch in Malabar improved, however, when the British turned their attention to Kanara and directed the troops from the Zamorin's country to Mangalore. This meant that there came an end to the period in which Cochin was continually threatened with a siege. In July 1783 van Angelbeek received even better news reporting that Britain and the Dutch Republic had agreed upon an armistice. ${ }^{355}$ From then onwards van Angelbeek must have felt more like an interested spectator than a party directly concerned with the lasting conflict between the British and Tipu. He watched colonel Fullarton who first took Coimbatore and then on 13 November Palghat. This conquest opened a way into the Zamorin's country and van Angelbeek consequently expected that the English, who were accompanied by the Zamorin, were going to reconquer this country. In that case they might also take Chetvai and Paponetty, and this van Angelbeek wished to prevent at all costs. When after the fall of Palghat he learnt that Haidros Kutti, who had been administering the districts of Chetvai and Paponetty for Tipu, intended to fly to Calicut he instructed the resident at Cranganore, Cellarius, to occupy these two places as soon as they were evacuated by the Mysoreans. This plan was carried into effect on 20 and 21 November. Van Angel-

353 L. f. B., 1783, I, Batavia to the Secret Committee for War Affairs, October 8, 1782.

354 L.f. C., 1783, I, Falck to Batavia, s.l., February 7, 1783.

356 L. f. M., 1783, I, Van Angelbeek to the Secret Committee for War Affairs, March 17, 1783; do., Van Angelbeek to The Seventeen, October 24, 1783. 
beek realized that he had to reckon with the possibility that Tipu would reoccupy the Zamorin's country. In that case he hoped that friendly negotiations might induce Tipu to leave the places in question to the Dutch. As a preamble to this policy he officially informed Tipu's commander at Calicut, Arshed Beg Khan, that the Dutch had occupied Chetvai and Paponetty. The reply was, however, unfavourable, for the Dutch were requested to evacuate the districts. ${ }^{356}$

Although it was not until February 1784 that Falck received the news of a preliminary peace-treaty between Britain and the Dutch Republic, ${ }^{357}$ the war had virtually ended long before. The result was that the Company in Malabar, unlike in the case of Coromandel where Negapatam remained in English hands, had suffered no territorial losses. But indirectly its position in Malabar had also been progressively weakened as a result of the increased influence of the British in Travancore.

Not only in respect of Travancore but also in general the British position in India had much improved during the last few years. Whereas in 1780 it seemed for a short while as if the English were definitely swept off their feet in the south by Haidar's impetuous attack, their situation had been retrieved in later years. Courage and diplomacy had brought about peace with the Marathas and so the nightmare of being up against two of India's strongest military powers at the same time came to an end. Three names are outstanding in this great struggle, those of Hastings, Macartney and Coote. But next to them there were so many others, often unknown to posterity, who like the defenders of Tellicherry played an important part and so contributed to the salvation of the East India Company's existence. It was only from then onwards that the English, whose organization as a result of Pitt's India Act of 1784 was soon to be based on a much improved structure, could really begin to reap the fruits of their energy and, consequently, start thinking of becoming the paramount political power in India.

356 L.f.M., 1784, I, Van Angelbeek to the Secret Committee for War Affairs, December 29, 1783.

357 L. f. C., 1785, I, Falck to the Secret Committee for War Affairs, September 17, 1784. After the armistice had been agreed upon in January 1783, a preliminary peace-treaty was concluded in September 1783. The definite peace-treaty followed in May 1784 (comp. H. T. Colenbrander, De Patriottentijd, I (den Haag, 1897), pp. 294, 305, 333). 


\section{THE DUTCH AND TIPU SULTAN, 1784-1790}

The war with the British being over van Angelbeek realized that it became necessary to establish relations with Mysore on a normal footing. The dispute on Chetvai and Paponetty had entered into a new phase as a result of the Dutch taking over these places. ${ }^{358}$ Secondly, Haidar's death had prevented the Dutch from sending a mission to Tipu in December 1782359 and his succession gave all the more reason as yet to carry out the original plan. But there was still another consideration which made a mission advisable in van Angelbeek's eyes, namely, the possibility of enlarging Dutch trade by means of a commercial treaty. He hoped to induce Tipu to sell cardamom, sandalwood and pepper to the Dutch exclusively, and in order to attain this object the Company should supply him with munitions at a cheaper rate than the competitors. This could be done by offering them at cost price, and the gains on the products of Mysore would be substantial. But even if these gains were less than he expected, a commercial treaty remained desirable because it would guarantee the Company the friendship of a powerful ruler who otherwise might be a dangerous enemy. ${ }^{360}$

When writing thus to Batavia van Angelbeek knew that peace between the English and Tipu was drawing near, and he rightly concluded that as the British could be expected to include Travancore as their ally in the peace-treaty, the Company would have no need, as before, ${ }^{361}$ to mention Travancore in its negotiations with Mysore. Nevertheless, van Angelbeek hoped that the ambassadors might find the atmosphere so friendly that Tipu would be willing to promise the Company that he would live in peace with its allies Cochin and Travancore. ${ }^{362}$ This shows that van Angelbeek looked upon the negotiations

\footnotetext{
358 P. 133 supra.

359 P. 130 supra.

300 L. f. M., 1784, I, Van Angelbeek to Batavia, February 8, 1784.

361 Comp. pp. 38, 43, 82, 95, 119, 120 and 121 supra.

362 L. f.M., 1784, I, Van Angelbeek to Batavia, February 8, 1784.
} 
with Mysore rather optimistically. The same follows from his ideas about the treaty of commerce. Of course, he could not know that the peace-treaty between Tipu and the British was to contain a clause about trade which would rule out the possibility of a monopoly as sought by him for the Dutch. ${ }^{363}$ But was there any reason to conclude from the past conduct of Tipu or of his father, generally, as well as particularly in their relations with the Dutch, that Tipu would ever contemplate conceding such a preferential treatment to the Company? Certainly, there was none and once again it looks as if a Governor of Cochin had lost sight of reality while dreaming of a brighter future for the Company in Malabar.

In January 1784 two ambassadors, Seijffer and Vernede, were appointed by the Cochin Council and Tipu was accordingly informed. ${ }^{364}$ But whereas no reply was received during the next months, rumours reached Cochin from Calicut that the Mysoreans were planning an expedition to retake Chetvai and Paponetty. Van Angelbeek decided to ask Arshed Beg Khan for an explanation and so he sent a letter and some small presents to this Governor of Calicut. Meanwhile, at van Angelbeek's request the Council at Colombo had expressed its views of the situation. Whereas the Council approved of the action taken so far by Cochin, at the same time it strongly advised van Angelbeek not to bring matters to a head. If it appeared that Tipu were unwilling to leave Chetvai and Paponetty to the Company the best thing would be to return the places to him. ${ }^{365}$

Arshed Beg Khan refused the presents and replied that no embassy could be sent to Tipu before Chetvai and Paponetty were evacuated. The Council at Cochin then decided to write to Tipu that the Company, although wishing to keep these places, would not do so unless he fully agreed to it. He was asked where and when the ambassadors could be received. Surion and two messengers were to travel to Seringapatam with this letter. ${ }^{366}$ It soon became clear, however, that this plan could not be carried out, for Arshed refused to give permission for the journey from Calicut to Seringapatam. At the same time he threatened the Company with war and although this was felt to be mere intimid-

363 C. Hayavadana Rao, History of Mysore, III, p. 1206 gives the text of clause 8 of the treaty of Mangalore relating to this matter. The text refers to the treaty of $\mathbf{1 7 7 0}$ between Haidar and the English Company which may be found on pp. 1105 et seqq. of the same work.

304 L. f. M., 1785, I, Secret resolutions of the Cochin Council, January 8, 1784.

305 L. f. M., 1785, I, Van Angelbeek to Batavia, April 20, 1784.

306 L. f. M., 1785, I, Van Angelbeek to Batavia, May 3, 1784. 
ation the Cochin Council decided on 20 May to send Seijffer and Vernede immediately to Calicut. They were instructed to try to find out whether Arshed indeed had received orders to recapture Chetvai and Paponetty. If this was the case and it appeared that the envoys were unable to make him change his mind they should promise Arshed the formal cession of the places. Thereupon they should proceed to Seringapatam, where they should first congratulate Tipu on his assumption of the government. Secondly, they should induce him to cede Chetvai and Paponetty by offering a lump sum of 150,000 rupees or, if he did not accept this, 10,000 rupees annually. As Tipu's revenue from these districts had amounted to 18,000 rupees, the only way to make this proposal attractive to him would be to offer payment in munitions at cost price. Thirdly, Seijffer and Vernede should conclude a commercial treaty.

On 12 June, however, a report from the ambassadors who had left Cochin on 26 May, reached van Angelbeek in which they wrote that Arshed remained adamant in the case of Chetvai and Paponetty. That same evening instructions were issued from Cochin to start evacuating the places which were subsequently transferred to Mysorean commissioners.

The instructions for the ambassadors were adjusted to the new situation and the general feeling at Cochin must have been that now nothing stood in the way of the envoys' proceeding to Seringapatam. Their letter of 21 June indeed pointed that way, for Arshed had shown his satisfaction about the Company's decision and had promised them help in every respect. Twelve days later, however, they reported that from day to day he postponed placing coolies at their disposal. Finally, they were told that Tipu had delegated the discussion of their matters to Arshed so that they need not undertake the expensive and difficult journey to Seringapatam. After having raised many objections the ambassadors agreed on condition that if Arshed could not settle the matters he would enable them to travel to the capital. When, however, they started broaching the subject of the retrocession of Chetvai and Paponetty, Arshed replied that he would have to consult Tipu on this point, and he advised them to await the result at Calicut. The envoys turned this down and requested his help for their journey to Seringapatam. Again the help promised was put off from day to day until Arshed declared that no coolies would be willing to go during the monsoon. Then Seijffer and Vernede decided to set out on the journey with the few coolies they still had and with some bullocks and horses 
they had bought at Calicut. The main reason for this decision was their discovery that the Mysoreans at Calicut having given wrong impressions about the Company to Tipu were afraid that their master would find out the truth through the envoys. ${ }^{367}$

Under the given circumstances the decision of the ambassadors was undoubtedly very courageous, for they had to reckon not only with the continual obstruction by Arshed but also with a journey without sufficient facilities during the worst time of the year. But if it were asked whether it was also a wise decision the answer can hardly be positive. For, even if they were right in their conclusion that Tipu's ideas about the Company were unfavourably influenced by his representatives at Calicut, the envoys might have wondered whether their proposals would be of such a nature as to turn the scales altogether. According to the altered instructions issued after the retrocession of the disputed area they were no longer free to offer any compensation, as under the changed circumstances van Angelbeek wished to be able to consult Batavia first.368 Thus the envoys could now only sound Tipu's opinion about this point but would never be able to settle it. It seems, therefore, that their courage and sense of duty were greater than their political wisdom when they decided to face all weathers in proceeding to Seringapatam.

Seijffer and Vernede arrived with their suite on 4 August 1784 in Tipu's capital after a most uncomfortable month's journey during which several of the small number of coolies deserted. They must have had some mixed feelings about their reception, for the quarters allocated to them were of such inferior quality that at first they preferred to live in their tents. On the other hand, they were provided with large quantities of food which were sent with great pomp on the day of their arrival, but this proved to be rather expensive as they had to give a present of five rupees to every one of the forty servants who brought the food. They were also especially welcomed by some dignitaries and servants of Karim Sahib which cost another 300 rupees. Five days elapsed before they were received in audience by Tipu. He was friendly but soon asked them to return the next day as there were too many people about. The following day the envoys were kept waiting for six hours before their audience began. After having handed over that part of their presents which they had been able to take along from Calicut,

367 L. f. M., 1785, I, Van Angelbeek to Batavia, September 10, 1784.

308 Loc. cit. 
they gave an exposition about Chetvai and Paponetty and mentioned the Company's wish to conclude a commercial treaty. On the former subject Tipu replied that he first had to consult the Governor of Calicut as its roots lay in events prior to his reign. He further expressed his willingness to enter into an agreement with the Company but said he preferred to continue the discussions at Calicut where he intended to arrive within a few months.

Although no purpose was served with a further stay the commissioners soon discovered that they were not free to leave. Tipu had sent orders to Calicut to bring the rest of the presents and the envoys were expected to await their arrival. Meanwhile, both of them fell ill and their financial position became difficult when they noticed that permission to leave was only obtainable through bribery. They succeeded, however, in borrowing 500 pagodas from a Kanarese and used the money to influence several people. Tipu's Armenian court-physician thereupon apparently had reported that the climate was unsuitable to them and a few days later they were summoned to an audience. Vernede was too ill to go and Tipu received Seijffer who made a last attempt to get a decisive answer about the disputed places and the commercial treaty, but Tipu repeated that he would expect two ambassadors at Calicut. There the matters would be settled satisfactorily and Chetvai and Paponetty would be handed back to the Company. When Seijffer requested the settlement of this affair now, Tipu flatly refused. After the envoy, to the best of his knowledge, had replied to some questions Tipu put about the political situation in Europe he was allowed to take leave.

Preparations for the journey back took another six days as hammocks had to be made for fifteen people who were ill. On 24 August the embassy left Seringapatam and after a stay from 8 to 13 September at Calicut, Cochin was reached on 18 September 1784. Both the envoys were so ill that at first they were not even able to report orally let alone in writing. Vernede died shortly afterwards but Seijffer recovered temporarily 369 and wrote his report some time later. In it he observed that all attempts to learn Tipu's real disposition towards the Company had been made in vain. According to the court-dignitaries his treatment of the embassy showed his friendly feelings towards the Dutch. The French corps of Lallee was in ill repute at the time and

360 Seijffer died on 21 November 1785 (L.f.M., 1788, I, Van Angelbeek to Batavia, April 18, 1786). 
the court-physician told the envoys that Tipu had no confidence whatever in any of the other European nations. ${ }^{370}$

So another embassy to a Mysorean ruler resulted in nothing. Its cost amounted to 13,443 rupees for the embassy itself and 14,256 guilders for the value of the presents to the Governor of Calicut, Tipu and his prime minister. ${ }^{371}$ Van Angelbeek's hope that the envoys at least might be able to conclude a commercial treaty so that the Company might profit immediately and thus be indemnified for the expenses of the embassy which were far higher than estimated, ${ }^{372}$ had proved idle. On the other hand, the announcement that Tipu was soon coming to Calicut made van Angelbeek fear that Travancore might be attacked and that Tipu would wish the Dutch to support his action, if not openly with troops, then secretly with munitions. Some remarks by the courtphysician to van Albedyll, commander of the escort of sepoys, pointed strongly in that direction. So, once again the situation looked grim, and it seemed that the Company finally would have to choose between Travancore or winning and preserving Tipu's friendship. ${ }^{373}$

Falck, asked for advice by van Angelbeek, thought that Tipu knew enough of international law not to resent Dutch neutrality in case the situation developed as van Angelbeek feared. For, assisting him against Travancore would mean enmity with the British without the possibility of relying on aid from the French as in the war which had just ended. But if the worst came to the worst, and Tipu should not be open to reason, van Angelbeek might consider whether it should not be secretly suggested to him to approach de Bussy $\mathbf{3 7 4}$ for Dutch assistance. If de Bussy in the name of the French king would ask for aid, the Company would not too closely investigate whether it was for the French at Mahé or for the Mysoreans at Calicut. But on the whole Falck preferred Travancore's survival, as this was in the interest of the

370 L. f. M., 1785, I, Van Angelbeek to Batavia, September 10, 1784; do., Van Angelbeek to Batavia, s.1., September 27, 1784. L. f. M., 1786, Van Angelbeek to Batavia, January 8,1785 ; do., Report of embassy to Tipu by Seijffer, November 30, 1784. The envoys had been advised by van Angelbeek to seek Lallée's friendship.

371 L. f. M., 1785, I, Instructions for Seijffer and Vernede, May 25, 1784.

L. f. M., 1786, Expense account of the embassy, November 30, 1784.

372 L. f. M., 1785, I, Van Angelbeek to Batavia, September 10, 1784.

373 L. f. M., 1785, I, Van Angelbeek to Batavia, s.l. September 27, 1784

374 This general, who in the period of French glory some thirty years earlier had played a prominent part in South Indian affairs, had returned to India shortly before the war between the English and French ended. 
Company. ${ }^{375}$ As it seemed necessary to comply with the request to send envoys to Calicut as soon as Tipu arrived there, Falck wanted to seize the opportunity to have the presents delivered which were originally meant for Haidar and dispatched from Batavia in 1782.376 They had been wandering about for a long time and most of them had been spoilt. Therefore Falck sent new presents to Cochin together with a letter for Tipu. ${ }^{377}$ When Falck died in February 1785 presents and letter were still lying at Cochin, and van de Graaff, his successor, sent a new letter for Tipu to Cochin. Informing him of his succession the new Governor indicated that the Company wished to live in friendship and alliance with Mysore. He explained in the same way as Falck had done why these gifts were sent. ${ }^{378}$ The presents, however, never seem to have reached their destination, for meanwhile it had become clear that an embassy to Calicut would be unnecessary for the time being as Tipu was not coming there because war had broken out with the Nizam and the Marathas. ${ }^{379}$ There were no further negotiations and van Angelbeek by now doubted whether a commercial treaty would ever be concluded. From Batavia's letter of 1 October 1784 he knew its opinion of his proposals for such a treaty. It objected to the idea of asking merely the cost price for munitions and expressed fear that the Company might be supplied with more cardamom and sandalwood than it could find markets for. Van Angelbeek met the latter objection and as for the first he referred to his original letter of 8 February 1784 about the political aspect of a treaty. Nor did he share Batavia's fear of difficulties resulting from a treaty in case of war between Tipu and the British. 380

The attitude of the High Government in this case gives another $\mathbf{3 8 1}$ example of the spirit predominant during this period. Lack of political imagination was accompanied with fear for the consequences of expan-

\footnotetext{
375 L.f. M., 1786, Falck to van Angelbeek, October 11, 1784.

378 Comp. pp. 123, 126, 131 supra.

377 L.f. M., 1786, Van Angelbeek to Batavia, s.l., April 30, 1785. L. f. C., 1785, III, Falck to Tipu, October 25, 1784.

378 L. f.M., 1786, Van Angelbeek to Batavia, April 30, 1785. L.f.C., 1786, III, Van de Graaff to Tipu, February 25, 1785.

378 In 1787 van Angelbeek reported that the presents originally bought for Tipu had been used as gifts to Rama-Varma (L.f.M., 1788, III, Van Angelbeek to Batavia, March 20, 1787). It may be assumed that the same applied to those sent from Ceylon.

380 L. f. M., 1786, Van Angelbeek to Batavia, s.l., April 30, 1785.

381 Comp. p. 58 supra.
} 
sion in the commercial field. ${ }^{382}$ If Batavia had objected in general to van Angelbeek's initiative on account of political considerations, there would not be as much reason for amazement as there is now. In fact, one would almost have expected that the High Government, the war with the British being over and Chetvai and Paponetty again in Mysorean hands, would have instructed Cochin rather to drop, if possible, the plan to start negotiations on a treaty of commerce. The idea, however, that the Company might run the risk of being over-supplied with cardamom and sandalwood sounds rather odd after the experiences of the pepper-contract with Travancore. As we shall see later on, van Angelbeek's doubt whether a commercial treaty would ever be effected came true. Therefore Batavia's attitude never had any practical consequences in this particular respect. But it may help to explain why van Angelbeek gradually came to believe that he could probably render the Company no greater service than by liquidating its possessions in Malabar by stages.

Meanwhile, Tipu was fully occupied with his war which did not proceed very well. At the same time risings occurred amongst the Moplahs and Nairs in Malabar. Although, therefore, there seemed to be little chance of trouble with the Mysoreans van Angelbeek thought it wise to remain on his guard against surprises. In this connection he particularly wished to keep Ayacottah and Cranganore, the key-point of Travancore's defence in the north, in a proper state of defence. ${ }^{383}$

In August 1786 Rama-Varma paid a visit to Cochin and van Angelbeek discussed with him the fulfilment of the pepper-contract. During the previous years the supply of pepper had decreased, partly as a result of increased sales to the British. It seemed as if, henceforth, the Dutch would have to be content with 1,500 candies of pepper a year. To make it somewhat more attractive for Travancore to sell more to the Dutch, van Angelbeek had proposed to Batavia in 1784 to pay more for what was supplied over the first 1,500 candies. In 1770 Senff

382 According to their letter of 12 December 1786 The Seventeen shared Batavia's view's. But at the same time they asked for 5,000 pounds of cardamom from Malabar because as a result of the needs of distilleries and breweries the turnover in Holland was increasing. By then, however, Tipu had prohibited its sale because he sold all cardamom himself to the Arabian coast where the demand by far exceeded the supply (L. f. M., 1789, I, Extract from the missive of The Seventeen to Batavia, December 12, 1786; do., Extract from the demand of goods for 1788, December 14, 1786, with marginal notes).

383 L. f. M., 1788, I, Van Angelbeek to Batavia, s.l., April 18, 1786. 
had already pointed out that the only means of getting more pepper would be by paying more, but at that time the High Government had turned down this idea for fear of continually rising prices. ${ }^{384}$ Since then Batavia's attitude had changed so that van Angelbeek could now raise the subject. When, however, he found out that Rama-Varma was merely interested in the question because it would give him an opportunity to seek confirmation of the 3rd article of the agreement of 1753, van Angelbeek immediately dropped the whole matter. For, according to that clause, the Dutch should assist Travancore if it were attacked, and obviously Rama-Varma was now apprehensive of Mysore's intentions. In order to attain his aim somehow, van Angelbeek thought it wiser to offer presents to several court-dignitaries for every 100 candies supplied over the first $2,000.385$

The Dutch Governor soon had reason to be satisfied with his policy of avoiding new commitments which might imperil future relations with Mysore, for Tipu succeeded in making peace with the Marathas. From the Dutch point of view this meant that Mysore could still be considered the only power able to counterbalance British supremacy. On the other hand, however, Tipu was a dangerous neighbour as long as his friendship was uncertain. Van Angelbeek did not want a close alliance as the price of winning his friendship and so he made another suggestion to The Seventeen. Knowing that Tipu would send ambassadors to France he wondered whether the home authorities could not use their influence in such a way that the king of France would declare to the ambassadors that Holland was his ally and that he recommended the Company to their master's favour. The result would probably be that Tipu would leave the Company alone! 386 It is hard to suppress a smile at the naivety revealed in this idea. But apart from the suggestion itself there is its background, the feeling that Tipu indeed was a dangerous neighbour but that without him things might go worse for the Company as the English supremacy would then be unchecked. Here, as before, $\mathbf{3 8 7}$ the dual aspect of the relations with Mysore manifests itself, but it is typical of the lack of sound political judgement that after more than twenty years of experience with the Mysorean rulers a

384 L. f. M., 1785, I, Van Angelbeek to Batavia, April 20, 1784.

385 L. f. M., 1788, III, Van Angelbeek to Batavia, March 20, 1787.

386 L.f.M., 1788, I, Van Angelbeek to The Seventeen, April 11, 1787.

387 Comp. pp. 32, 34, 57 supra. 
Dutch administrator could still believe that a simple request might induce Mysore to leave the Company alone. ${ }^{388}$

Before another six months had passed a new incursion by Tipu into Malabar seemed imminent. There were rumours that he would demand from the Dutch the islands near Cranganore formerly belonging to the Zamorin, $\mathbf{3 8 9}$ and two lakhs of pagodas as compensation for the assistance given to van Vlissingen at the time of the siege of Negapatam. Perhaps he would demand the fort of Cranganore as well.390 During September 1787 Mysorean troops indeed appeared near Cranganore but they soon withdrew.391 Regarding the compensation, Surion had reported already in 1785 that according to the Governor of Calicut Tipu considered himself entitled to two lakhs of pagodas as the amount alleged to have been offered by van Vlissingen for Haidar's relief-corps. According to the Mysoreans this corps had been defeated as a result of van Vlissingen plotting with the British. ${ }^{392}$ Van Angelbeek requested Batavia to send instructions how to act if these demands should be put forward. He added that he had no illusions about Tipu taking notice of the argument expressed earlier by the High Government, that the Mysorean troops by their misbehaviour had contributed to the fall of Negapatam.393 From another letter written a month later it appears that at Cochin the opinion had been formed that in any case Tipu would turn against Cranganore because rumours had been spread that this fort was in very bad condition after heavy damage by a gale in June. Van Angelbeek prepared himself for its defence in close collaboration with the rajas of Travancore and Cochin who promised

388 Van Angelbeek's suggestion had no practical consequences, for by the time his letter reached The Seventeen the political situation in Holland was changing completely. From being an official ally of France, since a treaty of 1785, the Dutch Republic now became allied with Great Britain and Prussia. In fact, before van Angelbeek wrote to The Seventeen, Tipu had already given a profession of his friendship for the Dutch in a letter of 28 December 1786 to Souillac, Governor of Pondicherry, with whom he agreed that as there existed friendship between France and Holland he, Tipu, should establish a good understanding with the Company (see W. Kirkpatrick, Select Letters of Tippoo Sultan to various public functionaries (London, 1811), p. 462).

389 See p. 39 supra.

390 L.f.M., 1788, III, Van Angelbeek to Batavia, s.l., September 18, 1787.

391 L. f. M., 1789, I, Van Angelbeek to Batavia, April 26, 1788.

392 L.f.M., 1786, Surion's account to the secretary Poolvliet, April 25, 1785. Soon after Negapatam's capitulation it had been rumoured that Haidar was going to demand reparation for the losses suffered as a result of assisting the town (L. f. C., 1783, I, Simons, Geeke and Ebell to Falck, July 10, 1782). 393 L. f. M., 1788, III, Van Angelbeek to Batavia, s.l., September 18, 1787. 
assistance in case of a Mysorean attack.394 Soon afterwards, however, it seemed that no immediate attack was to be expected,395 and in January 1788 van Angelbeek even thought that presently he might be able to return the 300 men to Ceylon whom van de Graaff had sent at his request during the last quarter of 1787.396

Meanwhile, the collaboration with Travancore in defence matters by no means meant that this country was also willing to fulfil its promises in the commercial sphere. On the contrary, van Angelbeek had more reason than ever to complain, for whereas formerly the evasion of the contract had always been carried out stealthily, now pepper had been sold publicly to Indian and European merchants. During discussions in January 1788 Dutch commissioners threatened the raja that if he did not assume a more obliging attitude the Company might be forced to sell Cochin to one of the other European powers. But a few months later van Angelbeek regretfully observed that unless new measures were taken no quantities of pepper worth mentioning could be expected in future.397

Once more rumours of war increased daily when in March 1788 a strong Mysorean army arrived in Malabar. On 5 April Tipu himself entered Calicut. Van Angelbeek learnt from d'Almeida, a Portuguese physician who before being expelled by Tipu had been Danish agent at Calicut, that the French had sent two envoys from Mahe to welcome the Mysorean ruler who now had taken the title of Pasha. The title of Sultan had passed to his son. The British had also sent an envoy from Tellicherry who was not at all well treated. On receiving this news van Angelbeek deemed it useful to have Tipu also welcomed by Dutch representatives and he, therefore, applied for two passports.398 On

394 L.f. M., 1788, III, Van Angelbeek to The Seventeen, s.l., October 18, 1787. 395 L. f. M., 1788, III, Van Angelbeek to The Seventeen, s.1., December 23, 1787. 390 L. f. M., 1789, I, Van Angelbeek to The Seventeen, s.l., January 14, 1788.

397 L. f. M., 1789, I, Van Angelbeek to Batavia, April 26, 1788; do., Report of van Spall and Scheidz about a mission to the raja of Travancore in January 1788. In 1786 Rama-Varma had stopped the supily of pepper to the British because until then they had failed to pay off a debt of 420,000 rupees incurred during the late war. The settlement of this affair was followed by a contract concluded in November 1787 according to which Travancore was to supply in 1788 to the British 1,250 candies of pepper, and was to receive 1,000 stand of arms, cloth and lead in exchange (Factory Records Anjengo, 5 (1785-7), Consultations, October 18, 1786, and November 19, 1787. Factory Records Anjengo, 6 (1788-9), fol. 183).

3ił L. f.M., 1789, I, Van Angelbeek to Batavia, April 26, 1788. Comp. about the question of Tipu's names and titles Rao, op. cit., pp. 562, 901-2, 1207, and M. H. Khan, History of Tipu Sultan (Calcutta, 1951), p. 9.

V.K.I. 31 
13 May, however, one of the two messengers used for this purpose returned to Cochin with the news that they had been kept on a string until the 8th, when Tipu had left with the army for Tambracheri. The other messenger, who had remained to see whether after all a reply would be given to the Company's application for passports, returned soon afterwards also empty-handed. ${ }^{399}$

Whereas during the tension in 1787 van Angelbeek had willingly accepted Travancore's offers for assistance in case Cranganore should be attacked, he showed less enthusiasm when Travancore in the spring of 1788 insisted on a closer alliance between the Company, Travancore and Cochin. For the time being he still sought to avoid too strong commitments. 400 It is hard to say whether disappointment at the poor supply of pepper had anything to do with this rather selfish attitude, but mutual trust was not promoted by the conduct of either party. It is, therefore, not surprising to find that Travancore suspected van Angelbeek of being in secret correspondence with Tipu.401

The raja of Cochin had been summoned several times to pay a visit to Tipu as a tributary. At last he obeyed and on that occasion found out that the plans concerning South Malabar had been postponed but not given up. ${ }^{402}$ When the raja returned from Palghat he was accompanied by an embassy of Tipu to Travancore. Rama-Varma reciprocated by sending some presents but at the same time continued preparing the defence of his country. During discussions with the Dutch in June Travancore's point of view was that the three powers should remain on their guard against Tipu who would undoubtedly try to carry out his plans during the next dry season. The Company should ask for reinforcements from Batavia and improve the defensive works of Ayacottah. First van Angelbeek objected to this proposal as being too expensive. But when Travancore subsequently requested him to cede Ayacottah, he promised to have the stronghold repaired. ${ }^{403}$

399 L.f.M., 1789, I, Van Angelbeek to Batavia, s.1., May 31, 1788.

400 L. f. M., 1789, I, Van Angelbeek to Batavia, s.l., May 11, 1788.

401 L. f. M., 1789, I, Van Angelbeek to Batavia, April 26, 1788.

102 L. f. M., 1789, I, Report of a conference between van Angelbeek and Gowinda Menon, representative of the raja of Cochin, June 26, 1788. Major Dirom in his book $A$ Narrative of the Campaign in India. which terminated the War with Tippoo Sultan, in 1792 (2nd ed., London, 1794) has included in an Appendix the translation of a letter written by Rama-Varma to Madras on 8 June 1788. According to his report on the meeting between Tipu and the raja of Cochin, the latter had been urged to drive the Dutch from Cochin with Mysorean assistance (pp. 289-90).

403 L.f. M., 1789, I, Van Angelbeek to Batavia, s.l., August 10, 1788. 
In August collaboration between the Dutch and Travancore became closer as a result of inquiries by the Mysorean commander of Chetvai about Cranganore and the islands near this fort. He wrote he understood that the Company wished to dispose of Cranganore and the islands to Rama-Varma who would accept the possessions in behalf of the British. He alleged that the islands were part of the Zamorin's country and in case van Angelbeek wanted to sell them the commander would be compelled to inform Tipu. Thereupon van Angelbeek consulted the Dellawa of Travancore and both realized that if Tipu found out that the islands, indeed, had been sold already to Travancore but were not to be handed over before the next year, as had been agreed upon previously, he might try to take possession of them before the transfer. For, in that case he could do so without violating his peacetreaty with the English. The result of the consultations was that the islands were immediately handed over to Travancore. Van Angelbeek replied on 24 August to the commander of Chetvai that he was surprised that he inquired about affairs which were none of his business as the islands had been ceded by the Zamorin to the Dutch more than 25 years before. It was therefore for politeness' sake only that he was informed that all islands between Cranganore and Ayacottah had been sold not to the British but to Travancore, whereas until then the Company had not thought of selling the fort of Cranganore.404

The significance of this last remark appears when in April 1789 van Angelbeek wrote to Batavia that during the negotiations on the sale of the islands he began to wonder whether the Company might not be relieved of much trouble with Tipu by selling Ayacottah and Cranganore to Rama-Varma as well. They were the only places where the Mysoreans might attack the Dutch without falling upon Travancore and thus violating the treaty with the English. In Travancore similar thoughts seem to have occurred, for the Dellawa intimated to interpreters of the Company that it would be a good idea if the Dutch ceded Ayacottah as well to his master. Later on he informed the Company that the raja was willing to buy Cranganore too. Van Angelbeek received the Dellawa at Cochin and told him that the Company probably would not agree to the proposal, mainly because its acceptance would imply giving up all hope of getting back Chetvai and Paponetty. Nevertheless, he promised to put the proposal before the High Government.405

404 L. f. M., 1789, I, Van Angelbeek to Batavia, September 9, 1788.

405 L. f. M., 1790, I, Van Angelbeek to Batavia, s.l., April 29, 1789. 
The reader, knowing that van Angelbeek himself for some time had been thinking of ceding the two places to Travancore, undoubtedly feels inclined to ascribe the opinion expressed before the Dellawa to the desire of a merchant to increase the value of his commodities. Further support to the probability of this explanation is given by the fact that in a new plan of defence which van Angelbeek sent to Batavia together with Travancore's proposal he indicated as his advice that the proposal should be accepted.405 At the same time he had reason to assume that Batavia would agree to the idea, for a letter from there of 28 November 1788 had intimated that the High Government was thinking of a closer defensive alliance with Travancore in case neutrality was impossible. Such an alliance seemed to be preferable to the prospect of continual unrest, especially if the English as allies of Travancore would be willing to guarantee it. Van Angelbeek assented to the idea but observed that it was very unlikely that they would do so, whereas without their guarantee the alliance would lose most of its value.407

Meanwhile, Tipu had again marched into Malabar after his subordinates had proved themselves unable to suppress the insurrection which had broken out in his dominions there. At first his attention was drawn to the north of the region where he got into difficulties with the English at Tellicherry. ${ }^{408}$ In May he moved with most of his troops southwards and soldiers of his appeared before Cranganore which was summoned to surrender. They met with a refusal and soon afterwards the army proceeded via Palghat to Coimbatore. Van Angelbeek concluded from the fact that Tipu had not brought his heavy artillery that the summons had been an act of mere bragging. On the whole, he was less inclined to expect an attack on South Malabar later in the year than the rajas of Cochin and Travancore. In his opinion the Company and Travancore were too well prepared. Moreover, Tipu could not cope with the English and the failure of his embassy to France should have made clear to him that no help was to be expected from that

408 L. f. M., 1790, I, Van Angelbeek to Batavia, s.l., April 29, 1789; do., New plan of defence by van Angelbeek, April 29, 1789.

407 L. f. M., 1790, I, Van Angelbeek to Batavia, s.l., April 29, 1789.

408 L. f. M., 1790, I, Van Angelbeek to Batavia, s.l., March 29, 1789. During their difficulties with Tipu in March 1789 the English at Tellicherry followed the same policy of refusing to admit political refugees (Factory Records Tellicherry, $8(1789-90)$, fols. 116-7) as the Dutch had done in 1766 and 1774 with respect to the Zamorin and his relatives. 
quarter. Nevertheless, van Angelbeek thought it wise to ask Colombo to keep some troops ready. 409

In July, however, information reached Cochin that Tipu intended to attack the Company in order to lure Travancore into hostilities against him resulting from assisting the Dutch. In that case the British would be unqualified to help Rama-Varma. The situation looked desperate, for Ceylon was unable to send reinforcements for the time being, the Dutch at Cochin were short of money, and Madras seemed unwilling to assist them against an Indian enemy. In van Angelbeek's view the only way out was to transfer Cranganore and Ayacottah immediately to Travancore. On 25 July he received a letter from RamaVarma requesting him to reconsider $\mathbf{4 1 0}$ the sale of the two places, and three days later it was agreed to accept an offer of three lakhs of rupees, only 50,000 of which to be paid in cash and the remainder to be deducted from the payment for pepper during the next four years. Hardly had the contract been concluded when Tipu's envoy Abdul Qadir Khan proposed to the raja of Cochin that he should try to buy Cochin from the Company. The reason given was that Tipu had learnt from Europe that the British wished to buy the town which would be harmful to the raja. Van Angelbeek informed the raja that he knew nothing about plans in Europe to sell Cochin to the British and that he thought it very unlikely that such a deal would ever take place. To Batavia he wrote, however, that the idea had struck him that Travancore on hearing of Tipu's proposal probably might request first claim. If this happened it would be necessary for the High Government to consider most seriously whether five million guilders or perhaps even more were not to be preferred to a settlement the upkeep of which outweighed its income.411

This suggestion of van Angelbeek, surprising though it may seem at first sight, is in a way the logical conclusion drawn by someone who had gradually become used to regard the Company's position in Mala-

409 L.f.M., 1790, I, Van Angelbeek to Batavia, s.l., June 4, 1789; do., Van Angelbeek to Rama-Varma, May 29, 1789.

410 On 10 July van Angelbeek had rejected a proposal of the Dellawa to sell the places..

411 L.f.M., 1790, I, Van Angelbeek to Batavia, s.l., August 30, 1789; do., Secret resolutions of the Cochin Council, July 28, 1789. Earlier, in June, Tipu had already written to the French at Pondicherry that they should try to purchase Cochin from the Dutch (see S. P. Sen, "Franco-Mysore Relations (1785-93)", Proceedings Indian Historical Records Commission, XXXI, part. II, Mysore, January 1955 (Delhi, n.d.), p. 35). 
bar as a lost cause. The opinion that the settlements in Malabar were unprofitable possessions had been expressed several times in the past, but now it was stated at a moment when the masters at home were more than ever before in need of money. At about the time that they received van Angelbeek's suggestion proposals on the same subject were made by Britain to the Dutch Republic. A special committee of the Chamber of Amsterdam, to which The Seventeen had delegated the matter, was set up in September 1790. Its task was to investigate the importance of Malabar and the proposals for its disposal.412

Van Angelbeek had based his idea on Rama-Varma's desire to increase his power, commerce and prestige, and on his great wealth.413 As he was probably right in both respects, the question arises why in that case he had been content with a cash payment of only one-sixth of the purchase-money for Cranganore and Ayacottah? The answer is that the desperate situation did not leave him much choice. Yet, it seems to be incorrect to conclude from this concession by van Angelbeek that circumstances were entirely in favour of Travancore. As early as April van Angelbeek had pointed out to Batavia that it was very unlikely that Rama-Varma, who always was keen on hoarding his money, could be induced to pay cash for Cranganore and Ayacottah. The raja would probably propose payment in instalments for which the Company's merchants were to give surety. ${ }^{414}$ Another point is that in July the initiative in negotiating was in both cases taken by RamaVarma, who, therefore, seems to have been exceedingly eager to conclude the transaction. Moreover, the price ultimately obtained was even slightly higher than the one first mentioned by van Angelbeek to Batavia.415 This is not exactly what might be expected when circumstances force a merchant to sell his goods. So these three factors, first, that van Angelbeek never expected cash payment in full, secondly, Rama-Varma's eagerness to come to terms, and thirdly, the price obtained, point to the fact that the Governor had a better hold on the

412 Documents relating to this subject, into which I shall not go further here, may be found in the General State Archives at the Hague, no. K. A. 4464 $\mathrm{R} / \mathrm{S}$ under the heading "Committee Sale Malabar".

413 L.f. M., 1790, I, Van Angelbeek to Batavia, s.l., August 30, 1789.

414 L. f. M., 1790, I, New plan of defence by van Angelbeek, April 29, 1789.

415 According to a calculation made in April Travancore should be made to pay at least $285,333^{1} / 3$ rupees. A later calculation put the minimum asking price on $287,866^{2} / 3$ rupees. During his negotiations van Angelbeek demanded 375,000 and eventually sold for 300,000 (L. f. M., 1790, I, Secret resolutions of the Cochin Council, July 28, and 29, 1789). 
situation than he ever made it appear. But is not this natural when more than one party is interested in a bargain, even if it is obvious that for many reasons the seller prefers one of them and is unlikely to sell to the other? In such a case the first prospective buyer can never be sure of his ground until the bargain is an accomplished fact. In this instance Travancore, moreover, had to reckon with the probability that if it did not buy quickly the other party might take the places by force which would have at least the same undesirable result as a purchase by Mysore.

The sale of the forts has attracted the attention of several authors. Furber has pointed out that the raja of Travancore, the Dutch, and the Cochin Jews needed each other, and that out of that need the clever scheme arose to thwart Tipu by selling the forts to the raja whose territorial integrity had been guaranteed by the British in 1784.416 A second interesting point he makes is that probably not a single silver rupee found its way into the Company's treasury as a result of the transaction because the Dutch had borrowed 50,000 rupees from local merchants a year earlier. ${ }^{417}$ As to the first point, I generally agree with Furber's view, although perhaps he creates too strong an inpression that the scheme was only devised after the alarming reports of war preparations against the Dutch had reached Cochin in July 1789. As we have seen before these reports only speeded up the execution of a scheme which had in fact been devised earlier. As far as the second question is concerned, van Angelbeek informed Batavia in 1790 that the 50,000 rupees promised as first instalment by Travancore had been received when due. ${ }^{418}$ According to the settlement Anda Setty, one of the three merchants concerned, had given a bond to pay 25,000 rupees at the end of August and another 25,000 at the end of September 1789. Together with the two others he stood surety for the remaining amount of 250,000 rupees. 419 Consequently, the merchants were financially far more involved in the whole transaction than Furber seems to assume. For, he wrongly states that merely the first 50,000 rupees were covered by security of the three merchants. ${ }^{420} \mathrm{Had}$ he been right, I do not think van Angelbeek would have accepted the settlement as easily as he did. Moreover, the Company's loan of August

416 Holden Furber, John Company at Work (Cambridge (Mass.), 1948), pp. 245-6. His "1783" for the treaty of Mangalore should be read as "1784".

417 Furber, op. cit., p. 246.

418 L. f. M., 1790, II, Van Angelbeek to Batavia, s.l., April 30, 1790.

419 L. f. M., 1790, I, Van Angelbeek to Batavia, s.l., August 30, 1789.

420 Furber, op. cit., p. 246. 
1788, which Furber refers to, had been redeemed during that same year when after the arrival of commodities from Batavia part of these were used for this purpose. ${ }^{421}$ It seems therefore difficult to reconcile Furber's hypothesis with these facts.

As far as the Indian writers on the subject are concerned I shall now deal with the viewpoints of Panikkar, Alexander and Khan.422

Panikkar, who is rather inaccurate throughout his book, states that after Tipu had offered to buy Ayacottah $\mathbf{4 2 3}$ from the Dutch, van Angelbeek immediately approached Rama-Varma and sold Cranganore and Ayacottah $\mathbf{4 2 4}$ to him. After giving the text of the agreement Panikkar continues :

"For this piece of double dealing Tipu's wrath would have fallen on the Dutch but for the complications arising from his attack on Travancore and the third Mysore War which it precipitated". 425

Yet, although it must be admitted that the Dutch knew of Mysore's interest in the forts I do not think that one can speak of real purchaseoffers made to them by Tipu unless the inquiries by his commander of Chetvai,426 or perhaps even the summons of Cranganore by his soldiers $\mathbf{4 2 7}$ should be regarded as such. It is, therefore, incorrect to accuse the Dutch of double dealing. They had the opportunity to cheat but there is no evidence that they used it in Panikkar's sense.

Alexander 428 states that Tipu, already having expressed his desire to buy Cranganore and Ayacottah which the Dutch were prepared to sell, opened negotiations with them at Palghat in 1789. Rama-Varma,

421 L. f. M., 1790, I, Van Angelbeek to Batavia, March 29, 1789. Van Angelbeek added in his report on this matter that the merchants had not requested any interest for the period of three months that the money had been advanced.

122 C. S. Srinivasachari in "A Note on the Genesis of the War with Tippu in 1789", Journal of Indian History XXVI, 1948 (Trivandrum, 1949), pp. 269-73, restricts himself to giving Furber's exposition.

${ }^{423}$ K. M. Panikkar, Malabar and the Dutch, p. 107. On the preceding page Panikkar speaks of a proposal to the Company to sell Cochin, Cranganore and Ayacottah, but he goes on to stress especially the importance of Ayacottah for Tipu in connection with his projected attack on Travancore.

424 Panikkar writes "Cochin" instead of "Ayacottah".

425 Panikkar, op. cit., p. 110.

426 P. 147 supra.

427 P. 148 supra.

428 In his The Dutch in Malabar this author generally supports his argument with more references to his sources than Panikkar does, although still too often none are given, as, for instance, in this particular case. 
realizing the danger, started discussions with the Dutch and as a result the forts were sold to him because the Company expected that he would be able to check Tipu's progress to the south. The transaction was made after serious consideration by the authorities in Cochin and Batavia.429 From his continuation I gather that rather than have us believe that this specific transaction had been seriously considered by Batavia before it was carried out, the author intends to indicate that from 1696 onwards the Dutch policy generally had been to reduce the fortifications in Malabar as much as possible. As to the first point he makes, no reference is given relating to the negotiations at Palghat and I have no reason to assume his statement to be correct. Finally, the forts were sold because van Angelbeek thought it might deter Tipu from advancing against South Malabar, whereas even if he did attack, the situation for the Dutch would be far better than before the cession. ${ }^{430}$ But there is no reason to suppose that van Angelbeek thought that the possession of these forts would enable Rama-Varma to check Tipu's progress.

Khan argues that soon after Tipu had made peace with the Marathas, he started negotiations with the Dutch for the purchase of the two places because they were keys to North Malabar. But while he was negotiating Rama-Varma decided to acquire them for himself.431 The unfortunate thing is that although, on the whole, his book is far better documented than either Panikkar's or Alexander's, notes sometimes are missing. This is also the case in this particular passage and it is, consequently, impossible to say on whose authority this statement is based. Then, after having dealt with another aspect, that of the part played by the British in the affair, which I shall not enter into here,432 Khan, in discussing the military value of the forts, observes that RamaVarma although knowing that this value was nil, nevertheless purchased them because of his apprehension that Tipu might suddenly take possession of them. According to Khan this apprehension was baseless for two reasons, first, because the two places were quite inconsiderable the acquisition of which was not worthy of serious competition, and secondly, because Tipu did not want them as spring-boards but for

420 Alexander, op. cit., p. 106.

430 L. f. M., 1790, I, Secret resolutions of the Cochin Council, July 28, 1789.

431 Khan, op. cit., p. 157.

432 Khan, op. cit., pp. 157-9. Khan does not mention that already Wilks gave his opinion on this question. Wilks came to a conclusion which in several respects is contrary to the one Khan now arrives at. Comp. M. Wilks, Historical Sketches of the South of India, III, pp. 41-5. 
the security of his own kingdom. ${ }^{433}$ I fail to see the relation between the baselessness of Rama-Varma's apprehension and the first argument. As to the second, it may be interesting to go back a few pages in Khan's book, where he deals with the earlier relations between Mysore and Travancore. There he observes that Haidar, convinced that as long as Rama-Varma remained unsubdued the hold of Mysore over Malabar would remain precarious, decided to invade Travancore. He then explains why Haidar could not carry out this plan and why Tipu was not free until 1787 to turn his attention to Travancore. ${ }^{434}$ There is nothing, however, in Khan's argumentation from which the reader may infer that although Rama-Varma's behaviour in Khan's eyes became worse and worse. Tipu made the important decision to abandon his father's offensive policy and to content himself henceforth with defensive measures.

In dealing with Rama-Varma's contention to the British that the Dutch never paid any tribute to the raja of Cochin and had an independent right to dispose of the forts, Khan refers to Moens to prove that the Company annually paid the raja half the income of the import and export duties. Moens wanted to buy off this right for a fixed sum, but according to Khan the raja refused as it was the only remnant of his former greatness. This showed that the raja claimed, and the Dutch recognized, his sovereignty over Cranganore, Ayacottah, Cochin and Quilon. Since he became tributary of Mysore his privileges were transferred to the latter and, therefore, Tipu claimed to possess a prior right to the purchase of Cranganore and Ayacottah.435 Now it should first be mentioned here that a few inaccuracies occur in Khan's commentary.436 Actually, it was Moens who observed that the plan to buy off the raja's right - to which The Seventeen had objected - on second thoughts seemed hardly realizable because it was practically the only remnant of the raja's former greatness. Moreover, Moens expected that Rama-Varma, who in fact was the master of the raja

\footnotetext{
433 Khan, op. cit., pp. 159-60.

434 Khan, $o p$. cit., p. 154.

435 Khan, op. cit., p. 160.

438 One of these is that Quilon is mentioned as one of the places under the raja's sovereignty. Quilon, first conquered from the Portuguese by the Dutch in 1658, was situated in the dominions of the ranee of Quilon, who was dependent on Travancore (comp. M. A. P. Roelofsz, De vestiging der Nederlanders ter kuste Malabar, pp. 165, 260, 291-2).
} 
of Cochin, would object to it.437 So, two points clearly find expression here: Moens does not state anything about a refusal by the raja and he points out that Travancore is likely to object to it. He does not even think of Mysore in this connection because in his and others' view the raja of Cochin was only a tributary of Mysore as far as his northern territories were concerned. 438 His southern dominions were under the suzerainty of Rama-Varma, as Moens writes. Whereas the Dutch themselves, indeed, never were in doubt about their right of possession of Cranganore and Ayacottah, the peculiar fact arises that Tipu in his later representations to them never used the argument put forward by Khan, that the Company recognized the raja of Cochin's sovereignty by paying him half of the duties. As will be seen presently, Tipu ultimately did claim his own sovereignty over the Company's possessions, but the question of tribute was then only brought to the fore in connection with an alleged annual tribute of 12 pagodas paid to his land-lessor near Cranganore.439

Whereas Cranganore and Ayacottah were handed over to Travancore on 5 August 1789, it was not until the end of October that van Angelbeek received a letter from Tipu. He then complained of the fact that the Dutch had garrisoned Cranganore with troops of Travancore as a result of which rebels from the north were being protected and were using the fort as basis for hostilities against his territories. Van Angelbeek was requested not to render asylum to these men at Cranganore. ${ }^{440}$ To this van Angelbeek replied that Cranganore had been sold to Rama-Varma, who, he was sure, would not be guilty of the actions complained of. Nevertheless, he would pass on the message to Travancore. ${ }^{441}$

Thereupon, Abdul Qadir Khan arrived as Tipu's ambassador at Cochin and was received by the full Council on 24 November. The envoy started by explaining that he had not brought any presents because just before his departure it had been rumoured at Tipu's court that van Angelbeek had left Cochin while his successor had not yet arrived. But Tipu would undoubtedly redress this as soon as he learned

437 "Menoir written in the year 1781 A. D. by Adriaan Mocns, Extraordinary member of the Batavia Council, Governor and Director of the Malabar Coast, Canara and Vingurla, for his successor", Sel. Dutch Records Madras No. 2 , p. 25.

438 See pp. 75, 94 supra and p. 160 infra.

439 See p. 156 infra.

440 L.f.M., 1790, II, Tipu to van Angelbeek, received October 31, 1789.

441 L. f. M., 1790, II, Van Angelbeek to Tipu, November 10, 1789. 
that van Angelbeek was still there. Then a discussion developed on the cession of Cranganore. The envoy requested van Angelbeek to take back the fort. The Governor replied that this was impossible, whereupon the next question was whether the Company would take over the fort if Travancore were willing to return it. Again there was a negative reply. Abdul Qadir continued that Tipu had sent him to Travancore to demand Cranganore so as to be able to give it as a present to the Company. When van Angelbeek said that he would not accede to this, the ambassador asked him to prevail on Rama-Varma to return Cranganore. Van Angelbeek then pointed out that it was not for him to do so but that the envoy being on his way to Travancore might have a try himself. After a pause Abdul Qadir said that in that case Tipu would keep Cranganore for himself. Van Angelbeek's reply that this was a matter between Travancore and Mysore led to an exchange of views on the situation of Cranganore which was on Tipu's territory, according to the envoy. As an argument he mentioned that it had belonged to the raja of Cranganore whose dominions had been conquered by his master. Van Angelbeek explained that, as the raja in exile would be able to affirm, the fort had been separated from the raja's territory long ago and that in fact it had been captured from the Portuguese in an official war. The ambassador then contended that the Company paid an annual tribute of 12 pagodas for its possession. The Governor denied this and explained that subjects of the Company had rented some plots on the territory of the former raja of Cranganore from Tipu's land-lessor. When they did not pay their rents in time the latter had approached the Company's resident who in order to avoid trouble had the rent collected and paid to the lessor. This had happened annually ever since. Abdul Qadir thereupon took leave promising to return after his visit to Travancore in order to fetch van Angelbeek's reply to a letter from Tipu previously handed over. ${ }^{442}$

The way in which this discussion was carried on by van Angelbeek makes one suspect that he almost openly gave expression to a feeling of disdain peculiar to someone who believes he has outwitted his opponent. When on the next day he learnt the contents of Tipu's letter from its translation annoyance mixed with this previous feeling. For, the letter was addressed to "Tipu's subject, the Dutch merchant at Cochin" and demanded that he should cause the Travancorean troops

442 L. f. M., 1790, II, Record of discussion with Abdul Qadir Khan, November 24, 1789. 
to evacuate Cranganore and garrison it with Dutch soldiers instead.443 Shortly afterwards van Angelbeek received a first indication that after all things might develop less happily than he had imagined, when he noticed that the English seemed to give credit to Tipu's contention that the Dutch should not have disposed of Cranganore without his permission. Under threat of not assisting him in the war which might result from it they urged Rama-Varma to return the forts to the Company. The raja invited van Angelbeek to meet him and during their conversation at Paravur on 9 December he asked whether the Dutch were willing to take back the forts in order to save him from English discontent. Van Angelbeek refused pointing out that it would not prevent Tipu from his hostile plans against South Malabar. RamaVarma assented but then asked to admit Powney, the British resident at his court, to the next conference to explain jointly to him the falsehood of Tipu's pretexts. Van Angelbeek declined this request as he considered it improper to submit the Company's rights and actions to a foreign power. Thereupon, Rama-Varma asked van Angelbeek to assist him since the British were unwilling to do so. This was a reasonable request but the Dutch were too weak to comply with it. Meanwhile, Abdul Qadir was still trying to carry out Tipu's commission but Rama-Varma did not wish to see him before he had consulted van Angelbeek and the latter reminded the ambassador when he sought a new audience, of his promise to visit Travancore first. During a second interview between Rama-Varma and van Angelbeek it was decided to introduce a few alterations in the letter drafted by the Dutch in reply to that of Tipu. In this answer van Angelbeek objected to Tipu's overbearing tone and replied that the Company had every right to act at will with its possessions. Rama-Varma promised to send Tipu an answer to the same effect but when the Governor received a copy of his letter he noticed that this promise had been badly fulfilled as a result either of the raja's faint-heartedness or of foreign influence.444

Van Angelbeek fully understood the seriousness of the situation when Powney and Knox, the commander of two English sepoy battalions at Paravur, testified to him that they had received instructions not to concern themselves with Cranganore and Ayacottah and to abstain from assisting Rama-Varma unless he were attacked in his own terri-

443 L. f. M., 1790, II, Tipu to the Company, received November 24, 1789.

444 L.f.M., 1790, II, Van Angelbeek to The Seventeen, s.l., January 14, 1790; do., Van Angelbeek to Batavia, s.1., April 30, 1790: do., Van Angelbeek to Tipu, December 13, 1789. 
tory. As it was unlikely that the Travancoreans would be able to hold their own at Cranganore and Ayacottah for long, Tipu might advance against Cochin without setting foot on Travancore's original territory. Consequently, van Angelbeek prepared the defence of Cochin and the evacuation of women and children to Ceylon. Rama-Varma concentrated his best troops at Cranganore where a strong entrenchment was prepared under the supervision of von Krause, an engineer lent by the Company to the raja. The fact that the Mysoreans could only expect to carry the fort by a regular siege probably explained, according to van Angelbeek, why they ultimately directed their attack on a spot in the original Travancore Lines $\mathbf{4 4 5}$ which were themselves far weaker. The attack took place on 29 December 1789. Afterwards von Krause, whom the raja had just dispatched to the Lines in order to introduce some improvements, wrote an account of the battle.446 At first the Mysoreans overpowered three batteries of the Lines but subsequently their flanks were subjected to fire from the woods. They were so surprised by the first round of fire that they fell into disorder. Then the Travancoreans advanced and the confusion increased. Those Mysoreans who had not yet been trampled down by their horses while retreating to the point from where they had invaded the Lines found that the sacks with cotton, used for filling up the ditch when they set out, as well as some powder-barrels, had caught fire. This forced them to jump from the ramparts. Their losses were estimated at over a thousand, whereas the Travancorean casualties numbered three hundred. Two horses had been shot under Tipu who was said to have been wounded by an arrow in his back. 447

Of course, the Dutch regarded the fact that the attack had taken place on ancient territory of Travancore as very fortunate, for, in

445 Line of defence constructed by Rama-Varma since 1761 to protect his northern frontier against Calicut.

446 L.f. M., 1790, II, Van Angelbeek to Batavia, s.l., April 30, 1790.

447 L. f. M., 1790, II, Account of the battle of 29 December 1789 by von Krause. Whereas according to von Krause the turning-point of the battle was after 2 p.m., Kirmani puts it at about daybreak, the cause being, according to him, the cutting down of a mound raised in a river to keep out the tide of the sea (M.H.A.K. Kirmani, The History of the Reign of Tipu Sultan (translated by W. Miles, London, 1864), p. 158). This explanation seems rather fantastic and, if true, probably would not have failed to make some impression on the Company's servants. Rao's narrative is a mixture of the descriptions by Wilks and Kirmani - which do not correspond with one another - and is for that reason unintelligible. Comp. Rao, op. cit., pp. 733-6 with Wilks, op. cit., pp. 46-50, and Kirmani, op. cit., pp. 157-9. 
their opinion, the British were now under the obligation to assist Rama-Varma. It took months, however, before they saw their expectation come true. During this period their own defence-measures were extended and auxiliaries arrived from Ceylon. Thirty-six gunners were lent to Rama-Varma, and according to van Angelbeek's report, they proved their value when the Mysoreans, who started to shell the Lines in March 1790, attacked in vain on the 16th of that month. The raja was so pleased with their performance that he appointed von Krause, who had commanded the largest battery, commander of his artillery. But a month later, on 15 April, another Mysorean attack met with success, the Lines were carried, and the Travancoreans dispersed in great confusion. That same night the raja of Cochin whose troops had also fled arrived at Cochin seeking Dutch protection. The whole country-side was made unsafe not only by marauding Mysoreans but also by other looters who tried to take advantage of the general confusion. 448

It was only after the fall of the Lines that van Angelbeek received an indication that the British were actually going to help Travancore when on 23 April lieutenant-colonel Hartley arrived with a detachment from Bombay off the Cranganore river. The Dutch assisted in piloting them and in placing the warehouse and powder-magazines at Cochin at Hartley's disposal for his munitions.449 But van Angelbeek's expectation that things might now take a favourable turn did not yet materialize. The English troops remained idle and Tipu conquered several forts of Travancore. When Cranganore also ran the risk of being captured it was evacuated on 6 May. The two armies faced each other on either side of the river near Paliaporte, and at the request of Travancore the Dutch sent more guns. When paymaster Paddock approached van Angelbeek on behalf of Hartley with the request to add Dutch troops to the English detachment, the Governor seized this opportunity to enter into negotiations for a closer alliance with Travancore under British guarantee as desired by the High Government already in $1788.450 \mathrm{He}$ drafted a pact of ten articles according to which the Company was to assist Travancore with 1,000 men and munitions. ${ }^{451}$

A few days later he received a letter dated 26 February 1790 and

448 L.f. M., 1790, II, Van Angelbeek to Batavia, s.l., April 30, 1790.

440 Loc. cit.

490 P. 148 supra.

451 L. f. M., 1791, I, Van Angelbeek to Batavia, s.l., May 14, 1790. 
forwarded by van de Graaff in which Governor-General Cornwallis urged the Governor of Ceylon to collaborate by keeping a watchful eye on the movements of the French. Van Angelbeek considered this a good starting-point to lift the negotiations with the British to a higher plane and so he sent his ten articles with an explanatory note to Calcutta.452 There were several reasons why van Angelbeek wished to support Travancore with troops. It was obvious that if the British alone helped in saving Travancore they would not fail to impress upon Rama-Varma that the Dutch had violated the treaty of 1753 . If, on the other hand, Travancore became closer united to the Dutch and so were induced to a better fulfilment of the pepper-contract, for which purpose a separate clause was inserted in the draft, this might consolidate the Company's position in respect of British influence. Secondly, officers and soldiers would get an opportunity to gain experience and ability which most of them lacked completely. Finally, taking part in the war might restore the Company's honour and prestige. 453

The expectation that the British were going to war was now at last confirmed to the Dutch by Cornwallis's letter and soon news arrived that an army had set out from Trichinopoly to invade Mysore. At about the same time Tipu withdrew northwards with the main part of his army, thus considerably reducing the tension among the Dutch at Cochin. However, another problem arose in May when the raja of Cochin intimated to van Angelbeek that he intended to apply to the English for restitution of his northern dominions if these were taken from Tipu. He seemed quite willing to become tributary to the British. Van Angelbeek fearing increasing English influence in South Malabar tried to dissuade the raja from taking this step, but in October he received a letter from Madras informing him that the raja had written that he wished to ally himself with the British and to renounce his allegiance to Tipu. Madras now inquired about the relations between the Dutch and the raja lest the good feelings between the two Companies should be disturbed. Van Angelbeek thereupon informed Powney that he did not object to the matter provided the Dutch interests were not harmed and the raja became a tributary of the English only so far as his northern dominions were concerned. Although the Governor refused to regard this development as a diplomatic defeat, at the same time

452 L.f.M., 1791, I, Van Angelbeek to Batavia, s.l., May 20, 1790; do., Cornwallis to van de Graaff, February 26, 1790; do., Van Angelbeek to Cornwallis, May 18, 1790.

453 L. f. M., 1791, I, Secret resolution of the Cochin Council, May 18, 1790. 
he had to admit to Batavia that Calcutta in a letter of 25 June had politely declined the proposal of a closer Dutch alliance with Travancore under British guarantee. Only in case of new threats to Travancore would the English turn to the Company and open negotiations on Dutch assistance.454 A second defeat? Van Angelbeek must have felt it as a set-back, but the High Government which originally had insisted on this policy changed its mind when it took notice of Cornwallis's first letter of 26 February 1790 . For, whereas Batavia's aim had been a defensive measure merely to protect Cochin from Tipu, this letter seemed to imply that Cornwallis wished to make a common cause of the whole war.455 This was definitely not Batavia's wish and before his second letter was known there, van Angelbeek was strongly recommended in a letter of 12 October 1790 not to become involved in any risky commitments and it was even suggested that it might be better to give up the whole idea of an alliance.456 Whereas Cornwallis's rejection was therefore not unwelcome to Batavia, it must have dealt a blow to van Angelbeek's hope of strengthening the Company's prestige and economic position. It is questionable, however, whether this hope was ever realistic, for even if the British had accepted his proposals it is difficult to see how this would have prevented them from gaining a dominant position in Travancore. The fact alone that they guaranteed the treaty would have given them a claim in that direction.

Meanwhile, the result of this rejection and of the development of the war was that the Dutch in Malabar once again became mere spectators. But this time unlike in 1783 their feelings were never divided as to the desirable outcome of the war: 'Tipu's subjection or, at least, the clipping of his wings to such an extent that his neighbours would have nothing more to fear from him in future. 457

$45-4$ L.f.M., 1791, I, Van Angelbeek to Batavia, s.1.. October 6, 1790. It was Powney who took credit for having prevailed on the raja to become tributary to the English (Factory Records Tellicherry', 8 (1789-90), Powney to Tellicherry, July 25, 1790).

455 Batavia's inference seems premature in the light of a letter which Cornwallis wrote on 28 February 1790 to Malet, British resident at Poona. There he expressed doubt as to the possibility of obtaining substantial aid from the Dutch and the Portuguese, and observed that in case a necessity should arise it would become advisable to endeavour to obtain co-operation and support from them (comp. N. B. Ray, ed. of “The Allies' War with Tipu Sultan 1790-1793", English Records of Maratha History, Poona Residency Correspondence, 3 (Bombay, 1937), pp. 78-9).

456 L. f. B., 1792, I, Batavia to The Seventeen, October 24, 1791.

457 L. f. M., 1791, II, Van Angelbeek to The Seventeen, March 27, 1791. 
Before it came to that, however, the Dutch were made to feel the destructive power of Mysore for the last time. On 3 August 1790 Mysorean horse rather unexpectedly made their appearance at Porto Novo. Although a few Europeans and sepoys at first offered some resistance they could not prevent the enemy from sacking the town once again. Topander, the Dutch agent who ten years before had found to his cost what Mysorean manners were like,458 now in time put himself in safety in a boat on the river from where, together with his Danish colleague, he witnessed the unfortunate events. He had found time to collect most of the cloth from the warehouse, and later on escaped by sea to Cuddalore. But the cloth on the bleaching-field and in the dye-works had all been carried off. 459 Half a year later it was decided to break up the factories at Sadras and Porto Novo and to recall the Company's servants to Pulicat to await more favourable times. Most of the inhabitants had fled and those who had stayed behind were so scared that trade had come to a standstill.460

Van Angelbeek more than anyone else on the Dutch side left his mark upon what turned out to be the final chapter in the Company's relations with Mysore. He seems to have been a person whose great commercial spirit amply made up for occasional lapses $\mathbf{4 6 1}$ from sound political judgement. During his tenure of office, which was to end in 1793 whereupon in 1794 he became the last Dutch Governor of Ceylon, the political ascendancy in Malabar shifted definitely to the British. Nothing pointed more clearly to this development than the attitude of the raja of Cochin who sought to exchange Dutch for English protection. Finally van Angelbeek had to resign himself to this new situation $\mathbf{4 6 2}$ but his previous conduct $\mathbf{4 6 3}$ makes it clear that he tried as best he could to slow down the fatal process and thus to maintain

458 It had just been decided to give him a douceur of 300 pagodas for the hardships he had suffered in 1780-1 (L.f. Cor., 1790, I, Tadama to Batavia, March 26, 1790).

450 This meant a loss of 3,822 pagodas, whereas the value of what had been saved came to 3,426 pagodas. L.f. Cor., 1791, I, Tadama to Batavia, September 26, and October 21, 1790. L.f. B., 1791, VII. Account of Topander regarding Porto Novo to Tadama and Eilbracht, September 27, 1790.

460 Sadras had never recovered from the Second Anglo-Mysore War. Of the 1,430 looms in 15 nearby villages previous to that war, only 184 were left in 178 . whereas at Sadras itself bleaching-fields and dye-works were lacking by that time. L. f. Cor., 1791, I, Eilbracht to Batavia, s.1., February 28, 1791. L.f. Cor., 1791, II, Eilbracht to Batavia, February 28, 1791.

161 Comp. pp. 136, 148, 161 supra.

462 See p. 160 supra.

463 See p. 157 supra. 
the Company's independence and freedom of action. The failure of his policy was the result of the tide being against him, not, it seems, of lack of ability.

As the peace-treaty of Seringapatam in 1792, indeed, clipped Tipu's wings so that he definitely lost his possessions situated near those of the Dutch, the raid on Porto Novo proved to be the last link in a chain of vicissitudes which characterized almost thirty years of relations between the Dutch East India Company and the rulers of Mysore, Haidar Ali and Tipu Sultan. 


\section{CONCLUSION}

The relations between the Company and Mysore can hardly be considered to have brought much credit to the Dutch. On the contrary, at first sight it might even look as if the whole picture is absorbed by cringing Dutchmen who most of the time were busy placating their new and mighty Mysorean neighbours. Or, in Alexander's words:

"In the course of the Mysorean invasions, the Dutch displayed a genius for "timid diplomacy" which made them appear ridiculous before the Malabar princes". 464

This author suggests that the main Dutch policy was to keep friends with the most powerful state without regard to previous treaty obligations. Thus the friendship of Travancore, Mysore, and the British was sought successively by the Company. 465 This view, however, is only true up to the point that the interests of other Malabar states were betrayed when the Dutch came to terms with Martanda-Varma in 1753. To suggest that the same happened in respect of Travancore when Mysore became dominant would be utterly wrong. It is one of the characteristics of the period that whatever turn events took, the Company always tried to protect Travancore from a Mysorean attack. The Dutch policy throughout the period was based on the preservation of the ties with this state. Undoubtedly, this policy was called forth by selfish motives and, possibly, it would have been abandoned under still greater pressure but, nevertheless, it was the actual line of conduct. Remembering how much of the trouble between Mysore and the Company arose out of this Dutch attitude one might even go further and suggest that on several occasions the Dutch might have gained more by giving up their interest in Travancore's existence.

There is yet another aspect to the fact that at the time of the Mysorean invasions the Dutch indeed let down a few allies. What they did in the case of the rajas of Cochin and Cranganore was not so very much different from what the British had done somewhat earlier with

404 P. C. Alexander, The Dutch in Malabar, p. 171.

$\$ 65$ Alexander, op. cit., p. 117. 
respect to several other rulers in the region. If there was a difference it was this, that whereas the English allies were sacrificed to the wish of the Bombay Presidency to expand trade with Mysore 466 this motive was lacking in the case of the Company.

In my view, this difference in approach to the new neighbour - the English keen on taking advantage in the commercial sphere whenever they could, and the Dutch merely mindful of self-preservation - is rather important. It illustrates perhaps better than anything else the gulf that had arisen between the mental outlook of these two Companies in India. On the one hand, the energetic and confident servants of the East India Company firmly believing in the growing commercial possibilities and the future in general, on the other hand, the Dutch servants who had lost practically all hope of a better future and no longer believed in expansion of their trade. At most, some of them occasionally dreamt of a brighter future.

To explain this difference in outlook as the natural result of a rising and a declining line of development does not seem quite satisfactory. In the case of the Dutch in Malabar at least there is a deeper cause. It can be found in the irresolution which from a very early date onwards dominated the Company's policy regarding this region. The upkeep of the military establishments proved to be a costly affair and the expenses were considered out of proportion to the commercial profits which never came up to the early expectations. Gradually the idea grew that Malabar was an unremunerative asset. At the same time, however, some arguments pleaded against abandoning these possessions. Canter Visscher, Dutch Reformed minister at Cochin about 1720 , mentioned its importance as a victualling-station for the Company's vessels sailing from Batavia to Mocha, or returning from Surat and Persia to Batavia. Furthermore, Malabar served as an outpost to protect Ceylon. It is interesting to note that the first reason Canter Visscher gave for Malabar's retention, namely, that the Company might remain masters of the pepper trade there, was dictated by fear that otherwise the Portuguese and English would step in.467 So here

466 In this respect several letters in Bombay Abstract Letters Received, 2 (1762-8), make some interesting reading, e.g. those from Bombay to the authorities at home of $25 \mathrm{March}$ and 14 December 1764 and 9 April 1766. As Menon observed: "In the presence of the most formidable enemy the Malabar Rajas had ever to encounter the East India Company threw them overboard" (K. P. Padmanabha Menon, History of Kerala, II (Ernakulam, 1929), p. 222).

$407 \mathrm{H}$. Drury, Letters from Malabar by Jacob Canter Visscher now first translated from the original Dutch (Madras, 1862), p. 39. 
we still 468 find a negative rather than a positive approach. The Company never succeeded in finding a solution to this dilemma. On the whole, its policy, vacillating as it was between curtailing the expenses and maintaining what had been acquired in the past, was defensive and not offensive. Under these circumstances it cannot be surprising that its servants did not really believe in future expansion.

If the question is put whether the combination of the different reasons brought forward for retaining the Dutch possessions sufficiently justified the policy of clinging to Malabar, the answer cannot be but negative. More and more the economic motives lost in importance, on the one hand because of the decline in the Company's trade to the areas situated to the west of India, and on the other hand because of the Dutch failure to keep the European competitors out of Malabar. The strategic argument which might have had some value at a time that the possibility of a Portuguese counter-attack from Goa had to be taken into account, could be discarded in later years in view of the British penetration into South-East India. Moreover, Malabar had become a liability rather than an asset to Ceylon's defence. No wonder therefore that occasionally Dutch voices were raised in favour of abandoning Malabar. Such a drastic step, however, would have required stronger moral courage, firmness and singleness of purpose than the higher authorities of the Company in Batavia and Holland were able to muster.

Yet, in spite of the weaknesses inherent in the Dutch position in Malabar I do not think that Alexander is entirely right when he states:

"But political power had slipped off their (i.e. the Dutch) hands long before, and therefore, they had ceased to matter in settling the affairs in the latter half of the 18th century".469

This sentence is part of a paragraph in which the exaggerated view is

468 Comp. p. 10 supra. The paragraph on Malabar in the General Instruction given in 1650 by the authorities at home to Batavia strongly points in the direction that the Malabar pepper was considered important not so much for its own value as on account of the danger that might arise in case it came entirely into the hands of competitors who might imperil the Company's sales and prices of pepper from other production centres (comp. P. Mijer, Verzameling van Instructiën, Ordonnanciën en Reglementen voor de Regering van Nedcrlandsch Indië (Batavia, 1848), p. 86). With respect to the Malabar cinnamon the Dutch approach in those early days was even more negative. To keep up the price of the Ceylon cinnamon it was thought necessary to extirpate the Malabar product (see M. A. P. Roelofsz, De vestiging der Nederlanders ter kuste Malabar, pp. 218-20, 312).

400 Alexander, op. cit., p. 171. 
given of the Dutch attempts to live in peace with Mysore which inspired the second sentence of this chapter. Perhaps this is the reason why Alexander has lost sight of the fact that but for the Company's opposition, both covert and open, to the Mysorean designs, Travancore might well have become subordinate to Mysore.

In a way the Dutch position became that of an admittedly weak, but even so, to some extent, effective buffer-state. Rao when dealing with Haidar's failings as a diplomat seems to have seen matters more in their true perspective. According to him, Haidar should have made the Dutch, who although declining were yet showing a resisting power not to be neglected, work for him against the rest on the West coast.470 So here it appears that the failure of Mysore's policy in the west had something to do with the Dutch. Their predilection for maintenance of the status quo meant that they did not completely cease to matter in settling the affairs in the latter half of the 18th century. It was a very modest part they played but, nevertheless, one with some significance for the historical evolution of both Travancore and Mysore.

In the foregoing there have already been opportunities to dwell on the figures of the Dutchmen who were prominent in the dealings with Mysore. What about their opposite numbers, the two Mysorean rulers? As it is, the Dutch records do not provide us with important contributions to the historical view of the personalities of Haidar Ali and Tipu Sultan. But this is not so surprising, for those Dutchmen who came into personal contact with them were apparently too much absorbed in their commissions or lacked the cultural interest for making observations in that respect, whereas the others were entirely dependent on second-hand information.

In Haidar's case two points crop up in the Company's records which both, at least according to contemporary Dutch interpretation, pointed to an early close of his rule: his usurpation 471 and his age. 472 While undoubtedly betraying a good deal of wishful thinking this interpretation was nevertheless to some extent a reflection of an existing feeling of doubt as to the stability of the position of Haidar and his family in South-Indian politics.

470 C. Hayavadana Rao, History of Mysore, III, p. 434. Poonen expresses himself even stronger when writing: "Again, it was the resistance of the Dutch Company which prevented Travancore from being subjugated by Hyder Ali" (T. I. Poonen, A Survey of the Rise of the Dutch Power in Malabar (1603-78) (Trichinopoly, 1948), p. 15).

471 See pp. 53 and 69 supra.

472 See pp. 92, 102 and 104 supra. 
Falck, however, who on the whole 473 strikes one as having been a greater realist than most of his compatriots does not seem to have been biased by similar considerations, and we therefore are on firmer ground when turning to him for forming an opinion about Haidar's repute. When retracing Falck's successive views on the relations with Mysore, we meet Haidar first as an esteemed potential ally, 474 then as a neighbour who should be appeased, $\mathbf{4 7 5}$ next as an aggressor, 476 and finally as a confederate whom one had to accept by stress of circumstances. 477

The sympathy, probably even mixed with admiration in the early days, soon gave way to misgivings about Haidar's political aims, and continuous suspicion and fear became the predominant elements in Dutch feelings with respect to Haidar.

Tipu, although in the very first period of his reign allied to the Company, later on cannot have been considered but a trouble-maker whose sole merit was his opposition to growing British supremacy. Applying like his father the method of raking up old grievances long after there had been a possibility for proper discussion, ${ }^{478}$ made him lose any claim to trustworthiness in Dutch eyes.

Two qualities which found stronger expression in Tipu than in his father, his interest in international affairs $\mathbf{4 7 9}$ and his desire to become a great merchant, 480 are mentioned in Dutch letters, but this only confirms our knowledge without adding to it.481

473 For a possible exception see Richmond's opinion that during part of the war with the British Falck's eyes "saw all of his own dangers but none of the enemy's difficulties" ( $\mathrm{H}$. Richmond, The navy in India 1763-1783. p. 229). It is a pity that so far no biography of this remarkable Governor of Ceylon has been written. Although Dutch historians generally consider Falck the last great figure of the Company's history they often display an appalling lack of knowledge about his career by the false representation that from 1783 until his death in $\mathbf{1 7 8 5}$ he lived the life of a private citizen.

474 Pp. 34, 36 supra.

475 Pp. 63, 64 supra.

476 P. 108 supra.

477 P. 120 supra.

478 An example in Haidar's case is the touching upon the question of the "Sandy land" after the embassy of 1775, in Tipu's that of Negapatam's fall after the embassy of 1784 (comp. pp. 90, 95, 144).

479 See pp. 139,140 supra.

480 See note 382 supra

481 Comp. Rao, op. cit., pp. 917, 1047; S. Sen, Studics in Indian History (Calcutta, 1930), p. 146; M. H. Khan, History of Tipu Sultan, pp. 331, 344-7; N. K. Sinha, Haidar Ali, p. 273. 
If therefore Dutch sources do not appreciably contribute to the historical view of the personalities of the two Mysorean rulers, their examination apart from illuminating the specific subject of this study, will, it is hoped, clarify a few questions of a somewhat wider significance.482 In this connection further reference may also be made to the Anglo-Dutch negotiations of $1780-81$, and particularly to the way in which they were terminated. In the existing literature we often come across the misrepresentation that these negotiations led to nothing because of the intervention of the Anglo-Dutch war. ${ }^{483}$ Other writers even enlarge upon this theme by giving Dutch procrastination as the reason why no treaty had been concluded before the arrival of the news of the war. 484 We have tried to prove that the facts of the case were different and, in order to avoid leaving behind a similar, that is to say wrong, impression about the close of the affair, it may be added here that on 21 May 1781 Hastings and Wheler, who at that time formed the Council at Calcutta, wrote to the Governor-General at Batavia :

“...We now think it necessary to acquaint you that in consequence of an unwillingness in the Nabab Wallajah $\mathbf{4 8 5}$ to consent to the treaty, the terms of it have not been proposed or communicated to the Government of Cochin and Colombo, and that we have relinquished the intention of prosecuting the measure".486

The example of these negotiations shows that when judging events in which the Company in the twilight of its existence was involved we have to exercise greater care than often has been done. Strong though the tendency may be to put most of the blame for the difficulties in which the Company found itself during the late 18th century on its own lack of vigour, it does not always give the correct answer. As far

482 See Appendices I and II.

483 See W. Fullarton, $A$ viezv of the English interests in India (2nd ed., London, 1788), p. 47; R. Caldwell, $A$ political and general history of the district of Tinnevelly (Madras, 1881), pp. 142-3; W. J. Wilson, History of the Madras Army, II (Madras, 1882), p. 104.

484 See G. R. Gleig, Memoirs of the Life of the Right Hon. Warren Hastings, II (London, 1841), p. 336; S. C. Grier, The Letters of Warren Hastings to his $W$ ife (Edinburgh, 1905), p. 85; H. C. Wylly, A Life of Lieutenant-General Sir Eyre Coote, K. B. (Oxford, 1922), p. 202. Datta points out that Madras and Muhammad Ali opposed the arrangement, but he accepts Gleig's view of Dutch procrastination and the intervention of the war (K. Datta, The Dutch in Bengal and Bihar, 1740-1825 A. D. (Patna, 1948), pp. 105-7).

$4 \$ 5$ Muhammad Ali.

486 L. f. B., 1782, VII, Hastings and Wheler to Batavia, May 21, 1781. 
as South India is concerned one may even go a step further and wonder whether after all the main cause of the Company's decline was not rather the fact that the Dutch were up against forces that were much stronger than they themselves could ever have hoped to muster in that area. From the moment the English and French shifted their commercial competition to a struggle for the political control of large parts of the country the Dutch were outclassed. This is not surprising, for even if at the time of this territorial struggle the Dutch had still been in the zenith of their power, it is difficult to visualize where they might have found the resources to take part in it vigorously. As the result of the war with Travancore had proved, however, the situation had already grown out of hand by the time the Company had to face almost simultaneously Mysore's policy of expansion and the gradually growing British influence. Either development presented a problem to the Dutch, the first that of military aggression, the latter that of economic and political penetration. As each problem by itself already appeared to hold a severer test than the Company could stand up to, the issue tended to shift to the question to which of the two dangers it would finally succumb. In the end the course of events averted the peril of being overwhelmed by Mysore, but by that time British penetration had already reached the borders of the Dutch possessions. A few years later events in Europe decided the issue definitely when, after the subjugation of the Dutch Republic by France, the English took possession of the Company's settlements in India and Ceylon. 


\section{THE ORIGIN OF THE NAIR REBELLION OF 1766}

Some interesting conclusions can be drawn from the Dutch letters with respect to Haidar's movements following his conquest of Calicut and to the origin of the Nair rebellion, conclusions which as will be seen do not correspond with the generally accepted view of these events. Beginning with the latter, Hayavadana Rao, when describing them, refers to Wilks, Kirmani, the Haidar-Namah, Robson, but mainly to de la Tour. Rao then writes:

"All this took nearly a month from the day Mana-Vikrama put himself to death in such an extraordinary fashion. Haidar then moved further south-west, with the view of reducing the country as far as Travancore, thus completing his designs of the conquest of the whole of the Western Coast from Goa onwards. He had the more reason to do this now, as he suspected that the sons of the Nair chiefs of Malabar - including those belonging to the Kolattiri and Zamorin families - had taken counsel with the kings of Travancore and Cochin, and had collected a large army at Ponnani, about 36 miles to the south of Calicut. Their forces assembled on the banks of the river of the same name, and were assisted by a few European gunners and Portuguese artisans. These, however, precipitately withdrew, immediately Haidar made his appearance. He pursued them as far as Cochin, some fifty miles further to the southward where, by the mediation of the Dutch, the king of Cochin made peace with him by agreeing to pay tribute to Mysore. Ponnani possessed a strong fort and it was garrisoned by Haidar immediately the Nairs retired before him. The example of Cochin was followed by the submission of the rest of the chiefs, including the Raja of Palghat, who all agreed to pay tribute and settle the alleged claims of the Mapillas. On these terms, their territories were restored to them, except that the nephews of the Zamorin were kept out of possession of Calicut and the territory subordinate to it. From Cochin, after a dreary and difficult march, in which many horses and cattle were lost, Haidar passed through the woods of Annamalais, receiving on the way tribute from the Rajas of Palghat and Cochin; and reached Coimbatore, towards the close of April 1766, 
where he cantoned. Before doing so, he posted Ali Raza-Khan with 3,000 infantry at Mannarkat, a large town and fortress on the frontier, about 18 miles west by south of Coimbatore and midway between Ponnani and Palghat.

Madanna at Coimbatore, however, did not fulfil expectations. His exactions and his lack of knowledge of the character of the people he had to deal with proved inimical to the success of his administration. Nor would the Nairs easily yield to foreign subjugation as Haidar seems to have thought. Their fiery zeal for independence and the imprudent measures of Madanna drove them into open rebellion. The secret help that the king of Travancore rendered them and the nephews of the Zamorin also evidently inclined them in the same direction. Ali Raja and his brother Shaik Raja had added their own quota. If they and Madanna had been more temperate in their exactions, the rebellion would perhaps have been less general. Within two or three months of Haidar's arrival at Coimbatore, he received news of a general rebellion of the Nairs throughout the invaded country". ${ }^{487}$

As more often is the case, de la Tour, Rao's main source for this part, seems to have mixed up several events. As related before, on page 31, Haidar's troops had reached Ponnani as early as the first half of April. At the same time it was reported from Cranganore to Cochin that there was a daily stream of fugitives from the north, amongst whom the royal families of Kolattiri, Kadattanad and Kottayam who went into exile to Paravur, whereas the relations of the Zamorin were still staying at Chowghat.488 Even if for one moment one might be inclined to assume that at that time Haidar's power extended itself to Ponnani for a very short period only, this suggestion is immediately refuted by the fact that the Dutch commissioners while on their way to Calicut expected to learn, and indeed did learn, that at Ponnani orders from Haidar had been received to accompany them on their further journey. 489 Likewise there is not a single indication in the Dutch sources that a large army had been collected by the Nair chiefs at or near Ponnani during the next month before Haidar had left the country. If for that reason he had been marching southeastwards 490 from Calicut, the commissioners on their way back to Cochin should at least have noticed some tumult when reaching Ponnani. On the contrary, it is expressly stated that no sooner had Haidar left for the

487 C. Hayavadana Rao, History of My'sore, II, pp. 576-8.

488 Hist. Acc., p. 9.

459 P. 39 supra.

100 Rao's "southwest" is a slip of the pen of course. 
east - from Ponnani - than a report dated 6 June 1766 was received at Cochin from Cranganore that the princes of Calicut had arrived there and had started gathering an army.491 Moreover, it would have been rather foolish of Haidar to have sent the main part of his army ahead from Ponnani to Coimbatore $\mathbf{4 9 2}$ if there had been any chance of a clash with a large Nair army near the coast. As for the reason of Haidar's staying behind at Ponnani for one or two days, I would like to suggest that he was anxious to know the result of the Company's negotiations with Travancore and Cochin. In the instructions for the commissioners sent to the rulers of these two states it is stated that after having explained the situation they should return immediately to report, so that Haidar who at Ponnani would await the reply to his latest letter to Breekpot, could get it as soon as possible.493 We have seen already that if Haidar did postpone his departure from Ponnani for this reason, the delay was in vain, for Breekpot did not answer until the 29th of May, that is to say, after Haidar had followed the main body of his troops.

Consequently, the whole episode of the pursuit of the Nair army by Haidar as far as Cochin must be deleted from Rao's description. As for the peace-making of Cochin's raja with Haidar, we have seen 494 that indeed consultations took place, first at Calicut, later at Vaikam and Cochin. The Dutch undoubtedly played a part in these discussions as a sort of go-between but it goes too far to say, as Rao does, that through their mediation a settlement was reached. First, there were other negotiations as well, directly between Haidar and representatives of the raja and indirectly through Surion. Moreover, although most probably tribute was promised by the raja during these discussions, no definite result was reached, as follows from Madanna's letter to Breekpot of 24 June 1766 in which he wrote about negotiations planned to be held with the rajas of Travancore and Cochin in Breekpot's presence. ${ }^{495}$ Rao's assertion that Cochin's raja paid tribute to Haidar on his way to Coimbatore cannot easily be brought into agreement with this statement.

It follows from what has been related before that Haidar may have reached Coimbatore during the first half of June. How Rao arrives

\footnotetext{
491 Hist. Acc., p. 16. See also p. 48 supra.

402 P. 48 supra.

493 L. f. M., 1767, I, Instructions for embassy to Travancore, May 25, 1766.

494 Pp. 42, 45-7 supra.

495 P. 48 supra.
} 
at his date of "towards the close of April" I am not sure, but it cannot be said that it arises logically from what he has written before. He assumes that Haidar reached Calicut on 20 April 1766 and that the Zamorin committed suicide subsequently. ${ }^{496}$ If sufficient time is allowed for the events described in the paragraph of his book quoted above, the date to be expected for the arrival at Coimbatore works out at about the same as that to which the Dutch sources point.

Haidar can hardly have stayed more than a few days at Coimbatore when the first reports of a rebellion reached him, for from what we have seen above, its starting-point may be determined to lie in the first week of June.497 In this respect Rao does not refer to de la Tour who gives May as the month in which the revolt started,498 but mentions Wilks and Robson as references when he says that "Within two or three months of Haidar's arrival at Coimbatore, he received news of a general rebellion of the Nairs throughout the invaded country".499

The clearer view of the consecutive events in their chronological order which I have tried to give in the foregoing, may be of some help in indicating the character of the rebellion of 1766 in Malabar. Concerning the causes of the rebellion Wilks expresses himself even more strongly than Rao does in the passage quoted before, when he writes:

"The civil governor to whom Hyder had entrusted the fiscal arrangements of Malabar, viewed its resources through the medium of the practices of exaction in which he had been educated; but was too little versed in the study of human nature to consider the habits and prejudices of a conquered people among the elements of his system of revenue. A quiet acquiescence in foreign subjugation was not to be expected under any circum-

498 Rao, op. cit., pp. 570-2.

497 It must be observed here that Breekpot in a letter of some four months later wrote that in the beginning of June Haidar with some troops had followed the army sent ahead and that in July the insurrection had broken out (L.f.M., 1767, I, Breekpot to Batavia, s.l., October 15, 1766). The fact that these dates do not tally with those given before must be the result of Breekpot's not consulting his former correspondence when writing this letter. It forms an interesting example of how soon even recent events are liable to misrepresentation if the writer relies only on his memory.

$40 \mathrm{~s}$ M. M. D(e) L(a) T(our), The History of Hyder Shah, and of his son, Tippoo Sultaun (rev. ed., London, 1855), p. 73.

499 What F. Robson says on p. 37 of his book, The Life of Hyder Ally (London, 1786), referred to by Rao, op. cit., p. 578 note 480 , is in fact, that about two months after Haidar had left Calicut this place was conquered by a brother of the late Zamorin and that Haidar on receiving news of this disaster immediately detached an army. Rao reports this in his note as: "Robson says that the rebellion occurred "within two months" after Haidar's departure", which is not exactly the same. 
stances from the natives of Malabar, but the imprudent measures of Madana precipitated their rebellion: and three months had not elapsed after Hyder's arrival in Coimbetoor, before intelligence was received that the Nairs had risen in all quarters:" 500

To my mind, however, Madanna simply did not have enough time to do as much harm as he has been accused of, for between Haidar's departure from Calicut and the start of the rebellion not more than three weeks elapsed. I would not like to say that Madanna would shrink from stripping his subjects to the skin if he saw his chance, and at that time he probably had more reason than ever to try to fill his pockets. For only recently he had been in disfavour with Haidar and had been fined the enormous sum of 160,000 pagodas. The reason was said to have been that he arrived at Calicut with only 8,000 men instead of 20,000 as had been ordered. ${ }^{501}$ So there is no reason to doubt that he would squeeze his new subjects had he been given sufficient time. However, assuming that Madanna started his exactions immediately after Haidar left, which he doubtless did, even then the time factor makes it difficult to accept his behaviour as one of the causes of the revolt. I suppose that Madanna did not change his policy and that it is mainly the harm he did later on along the same lines which, in the eyes of de la Tour and Wilks, made him co-responsible for the origin of the rebellion in 1766. The insurrection, as I see it, was merely the result of the repugnance against foreign domination among the Nairs who were immediately ready to rally round their princes when these made preparations for the reconquest of their countries. It is even quite questionable whether Haidar had been able to complete his conquest of those countries before he had to leave for Coimbatore. For if we may believe a letter of 13 May from the Dutch commissioners at Calicut to Cochin, troops which had been sent out to capture a fort had come back unsuccessfully. It was reported that 500 Nairs in the fort had made such a successful stand against Haidar's troops that their commander had been obliged to retreat to Calicut with 2,000 survivors.502 Sinha also holds the view that when Haidar returned to Coimbatore "Malabar had in reality been only half-subdued", but although this author has made use of the "Historical Account" in

\footnotetext{
:xoo M. Wilks, Historical Sketches of the South of India, I (London, 1810), pp. $475-6$.

501 Hist. Acc. p. 13.

502 Hist. Acc., p. 14.
} 
addition to Peixoto, his main source for this passage, he otherwise keeps more in line with the generally accepted view by stating that "After they had been at Coimbatore for 25 days, news reached them of the rebellion in Malabar" and that "The revenue measures of Madanna which were in violation of the customs of Malabar precipitated a crisis". 503

603 N. K. Sinha, Haidar Ali, p. 150. 


\section{THE CONQUESTS OF COORG AND CALICUT IN 1773-1774}

According to Rao Haidar advanced against Coorg in March 1774, and this might seem to fit in with what Dutch sources tell us 504 but for the fact that he rejects the idea of an earlier conquest in 1773. It is true that he quotes two sources, Wilks, and Mostyn's Diary, which date the conquest in November, and about June 1773 respectively, but he prefers to rely on the Haidar-Namah, ${ }^{505}$ which places it in MarchJune 1774.506 In doing so and yet following Wilks's description of Srinivasa Rao's army which, "marching through Wynad by the Pass of Tambracheri, descended at once on Calicut", 507 he leaves out the logical link which, at least, there is in Wilks's story that Haidar first had to possess the intervening country of Coorg and Wynad between Mysore and Malabar if he was to use a more direct route to Malabar than the two long and circuitous routes via Kanara in the north or Coimbatore/Palghat in the south which he had used before. In fact, Wilks writes that immediately after the conquest of Coorg in November 1773 Srinivasa Rao's army was detached along the just mentioned route against Calicut. ${ }^{508}$ Relying upon the Dutch sources which describe the attack on Coorg in April 1773 and Srinivasa Rao's army as advancing along the ancient route of Palghat,509 I cannot agree with

504 Comp. pp. 73 and 76 supra.

505 "The earliest available contemporary local chronicle in Kanada, bearing on the life and times of Haidar, completed about two years after his death", C. Hayavadana Rao, History of Mysore, I (Bangalore, 1943), p. XXIII.

506 Rao, op. cit., III, pp. 200-1. An earlier passage in Mostyn's Diary than the one Rao refers to indicates that the conquest took place before June 1773 . On 10 June 1773 Mostyn wrote: "Heyder has been employed by all accounts the best Part of this Season in reducing the Corack Rajah...." (The Third English Embassy to Poona, ed. by J. H. Gense and D. R. Banaji (Bombay, 1934), pp. 166-7).

507 Rao, op. cit., p. 199.

508 M. Wilks, Historical Sketches of the South of India, II (London, 1817), p. 158.

509 Pp. 73-4 supra.

V.K.I. 31 
Wilks's view either, but, at any rate, there is more logic in his narrative than in Rao's. Sinha also takes the view that Coorg and Wynad were occupied in the second half of 1773 in order to facilitate the reconquest of Malabar, and that Srinivasa Rao subsequently advanced through Wynad on Calicut.510 The Dutch source which mentions the invasion of Coorg by the ruler of Kottayam states that he took his chance when he noticed that the Mysoreans were busy in the Zamorin's country. 511 It is therefore possible that a detachment of the Mysorean army indeed took the new route through Wynad, say in December 1773, when there was still no trace of unrest. But, even in that case, Srinivasa Rao was evidently not the commander of this detachment. This may have been Saiyid Sahib, who is mentioned by several writers - probably after Wilks - together with Srinivasa Rao in their description of the descent via the Wynad route. An indication that part of the Mysorean army had indeed arrived via the central route before trouble started in the intervening countries might perhaps be found in a remark by Moens in a letter of $28 \mathrm{March} 1774$. He states here that it was said that Haidar's troops were preparing to partly retrace their steps northwards before long so as to occupy Kottayam, where the Zamorin and the ruler of Coorg were said to be staying. ${ }^{512}$ However, one might equally maintain that the stress in Moens's remark "partly retrace their steps northwards" should be put on the last word, the meaning then being that the troops had indeed proceeded via the southern Palghat-route as he had described, but might now go back to the north. I still feel inclined to assume that the central route played no part in the conquest of Calicut, and was only taken into use shortly afterwards. 513 However this may have been, it is more important that it appears from Dutch sources that the greater part of Coorg was twice

510 N. K. Sinha, Haidar Ali, p. 155.

sy Hist. Acc., p. 20. See also p. 76 supra.

512 L. f. M., 1775, I, Moens to Batavia, March 28, 1774. The words "Haidar's troops" are of course not to be taken in the sense that Haidar himself was present, for the description in the Historical Account makes it quite clear that he attacked Coorg and Kottayam coming from Seringapatam (see p. 76 supra).

513 A letter from Tellicherry of 30 January 1774 says - after the conquest of Calicut had been described - that it was generally expected that Haidar would make further conquests on the coast, and especially in the Kottayam and Kadattanad dominions where it was said that detachments of his troops were now "falling down" from Mysore (Letters Received From Bombay, 4, 8 January 1773-5 April 1776, Tellicherry to Court of Directors, January 30, 1774). 
occupied, first in April 1773, and again about March 1774. Did this escape the general attention because the first attack assumed the character of an, apparently, not carefully timed raid? It is true that most of the troops had to leave the country on account of the rains before the whole area had been occupied, but, on the other hand, the fact that garrisons were left behind in the conquered strongholds 514 gives the operation the aspect of an occupation and not of just a raid.

614 P. 73 supra. 


\section{THE MYSOREAN-DUTCH AGREEMENT OF 1781}

Agreement between His Highness Hazareth Nabob Hyder Ally Cawn Behaudar Sahib and the Honble Reynier Van Vlissingen, Governor, and Director on behalf of the Honble Dutch Company at Nagapatnam

Done in Council

1.

Whereas Contests have arose, between the Dutch and the English, and War declared, so the Nabob is during the war and whenever Negapatnam or any of our settlements are attacked by the English, to come to our assistance with his troops, and to attack the enemy in order to drive them from thence, whereby the settlements of the Honble Company will remain unmolested.

2.

Guns, firelocks and ammunition etc. which the Nabob may have occasion for shall be delivered to him by the Dutch at prime cost.

\section{3.}

Whereas we have entered into an agreement of mutual friendship, so the Dutch are to assist His Highness during the present war, which the English may carry on in the country and send him from hence, seapoys, Europeans and Mallees, guns, ammunition and stores etc. under the command of European officers, and the expences thereof to be paid by the Company - and after that the aforesaid people have joined the troops of the Nabob, His Highness is then in a good place to provide them with lodgings, and they are to be under the command of a chief officer.

The affairs of the Nabob may then be done by the aforesaid officer. 
4.

Whenever a peace is made between the Dutch and the English, and we thereof receive accounts from Europe, we then shall take the earliest opportunity to communicate the same to the Nabob and conform themselves agreeable to His Highness's desire.

5.

When any of the English either one way or other might arrive in any of the Dutch settlements, we then shall immediately arrest them.

6.

A Vakeel and ten harkaras of the Nabob are to reside in Negapatnam, and from us an able European Vakeel of the Company's is to be sent to reside with $\mathrm{His}$ Highness. In the meantime the people of both sides are to be paid all honors.

7.

At the arrival here of the combined French and Dutch fleets or even the Dutch fleets alone, the Dutch are to drive away the fleets of the enemy to the satisfaction of His Highness.

8.

And whereas the enemy from Tanjour and Trichinopolly may act against the troops of His Highness's who are stationed at Comboconum, so the Honble Company promises on their part, to send from hence to thence 2000 men, including Europeans, Mallaeis, and sepoys, together with 5 or 6 pieces of cannon, and European officers in order to join the aforesaid people of the Nabob and to rout the enemy.

And if the English lay siege to Negapatnam the Nabob is to send his troops in order to drive them from thence.

In the meantime the Company promises that at the arrival of the aforesaid people of His Highness, that they will provide for them good lodgings.

9.

Since His Highness the Nabob has been graciously pleased to give over to the Dutch Company places belonging to Tanjour viz the provinces of Kiwaloor, Weedaruccuum, Toppotoor and Nagore, with 
the villages depending thereon, so shall their Honors in all these places, send their people to prevent any grain or other provisions being exported to the enemy. And with regard to the expences of the detachments which by the Honble Company may be sent to the assistance of His Highness it shall hereafter be settled.

10.

At the arrival here of the Dutch ships from Europe and Batavia with a great number of troops both Europeans and Mallees the Dutch will come to a near agreement about the expences.

11.

The Dutch with a sincere heart received great satisfaction in the prosperity of Your Highness and shall conform themselves agreeable to your Highness's desire.

So far agreed and unanimous in the citadel of Negapatnam the 4th Sept. Anno 1781

For the translation

Dormieux

Voor de oversetting Dormieux

This text is a true copy of pages $233-40$ of Home Miscellaneous Series no. 161.

In view of the circumstances under which it was concluded the Coromandel Government could be satisfied with the agreement. No excessive demands were made by Haidar in spite of the fact that, whatever different suggestions might have been made previously, it was he and not the servants of the Company who finally drafted the treaty. The contents of most clauses point to this fact. It cannot be assumed for instance that the 9th article concerning the cession of territory originally belonging to Tanjore was included at the request of the Dutch. This would have been inconsistent with their cautious policy, for such a proposal might easily have led to later repercussions. The clause rather shows that it was Haidar's aim to complicate matters by sowing discord between old allies so as to increase the Company's dependence on him in the future. 


\section{BIBLIOGRAPHY}

\section{WORKS OF REFERENCE}

Arrowsmith, A., Atlas of South India. London, 1822.

Atlas of the Madras Presidency. Madras, 1907.

BIRDWOoD, G., Report on the Old Records of the India Office. 2nd repr. London, 1891.

Blagden, C. O., Catalogue of Manuscripts in European languages belonging to the Library of the India Office. Vol. I: The Mackenzie Collections. Part I: The 1822 Collection \& The Private Collection. Oxford, 1916.

Davies, C. Collin, An Historical Atlas of the Indian Peninsula. Madras, 1953.

Forrest, G. W., ed., Alphabetical Catalogue of the Contents of the Bombay Secretariat Records (1630-1780). Bombay, 1887.

The Imperial Gazetteer of India. New ed. Oxford, 1907-09.

Hill, S. C., Catalogue of Manuscripts in European languages belonging to the Library of the India Office. Vol. II. Part I: The Orme Collection. Oxford, 1916.

Hill, S. C., Catalogue of the Home Miscellaneous Series of the India Office Records. London, 1927.

Joppen, Сн., Historical Atlas of India. 4th ed. rev. by H. L. O. Garrett. London, 1938.

Jurriansse, M. W., Catalogue of the Archives of the Dutch Central Government of Coastal Ceylon 1640-1796. Colombo, 1943.

KAN, J. vaN, Compagniesbescheiden en aanverwante archivalia in Britsch-Indië en op Ceylon. Batavia, 1931.

Kan, J. van, "List of Records of the Dutch East India Company settlement on the Coromandel Coast 1702-1795", Verhandelingen van het Koninklijk Bataviaasch Genootschap van Kunsten en Wetenschappen, LXXI, part 1. Bandoeng, 1932.

KAYE, G. R. and Johnston, E. H., India Office Library Catalogue of Manuscripts in European languages. Vol. II. Part II: Minor Collections and Miscellaneous Manuscripts. Section I. London, 1937. 
Press List of Ancient Dutch Records from 1657 to 1825. Madras, n.d. (circ. 1897).

Realia. Register op de Generale Resolutiën van het Kasteel Batavia. 1632-1805. 3 vols. Leiden \& 's-Gravenhage-Batavia, 1882-86.

Resandt, W. Wijnaendts van, De Gezaghebbers der Oost-Indische Compagnie op hare Buiten-Comptoiren in Azië. Amsterdam, 1944.

Sutron, S. C., A Guide to the India Office Library. London, 1952.

Yule, H. and Burnell, A. C., Hobson-Jobson. New ed. edited by W. Crooke. London, 1903. 
II. UNPUBLISHED RECORDS

\section{A. General State Archives}

In order to find one's way in the "Overgekomen brieven" a table of contents which is available in manuscript in the Archives should first be consulted (Register van overgekomen papieren uit Indië en de Kaap, 7 vols., K.A. 4463, 4464, 4464 a-e). This “K.A." stands for "Koloniaal Archief", the classification under which these records are to be found. The K.A.-numbers have been added to the volumes consulted which are listed below.

1. Overgekomen brieven van Batavia (Letters from Batavia):

\begin{tabular}{|c|c|c|c|c|c|c|c|c|}
\hline Year & & K.A. & Year & & K.A. & Year & & K.A. \\
\hline 1758 , & VI & 2786 & 1770 & I & 3142 & 1782 & VI & 3484 \\
\hline 1759, & I & 2803 & 1771, & II & 3171 & 1782 & VII & 3485 \\
\hline 1759, & VI & 2808 & 1771, & IV & 3173 & 1783 & I & 3496 \\
\hline 1760 , & III & 2834 & 1772 & $\mathrm{~V}$ & 3204 & 1783 & IV & 3499 \\
\hline 1764 & V & 2962 & 1773 , & I & 3230 & 1784 & I & 3521 \\
\hline 1765 & VIII & 2994 & 1773 & II & 3231 & 1784 & II & 3522 \\
\hline 1766 & I & 3017 & 1778 & III & 3365 & 1784 & III & 3523 \\
\hline 1767, & I & 3050 & 1778 & VI & 3368 & 1785 & I & 3546 \\
\hline 1767 , & II & 3051 & 1780 & III & 3424 & 1785 & IV $\mathrm{B}$ & 3550 \\
\hline 1768 & II & 3080 & 1781, & III & 3451 & 1787 & I & 3598 \\
\hline 1768, & III & 3081 & 1781 , & $\mathrm{V}$ & 3453 & 1791, & VI & 3762 \\
\hline 1769, & II & 3109 & 1782 & II & 3480 & 1791, & VII & 3763 \\
\hline 1769, & III & 3110 & 1782, & III & 3481 & 1792, & I & 3805 \\
\hline 1769, & VII & 3114 & 1782 & IV & 3482 & $\begin{array}{l}1794, \\
1794,\end{array}$ & $\begin{array}{l}\text { III } \\
\text { IV }\end{array}$ & $\begin{array}{l}3862 \\
3863\end{array}$ \\
\hline
\end{tabular}


2. Overgekomen brieven van Ceylon (Letters from Ceylon):

\begin{tabular}{|c|c|c|c|c|c|c|c|c|}
\hline Year & & K.A. & Year & & K.A. & Year & & K.A. \\
\hline 1756, & IV & 2748 & 1766 & VI & 3034 & 1780 & II & 3436 \\
\hline 1757 & IV & 2774 & 1767 & I & 3063 & 1781 & I & 3463 \\
\hline 1758 & II & 2792 & 1767 & III & 3065 & 1781 & II & 3464 \\
\hline 1758 & III & 2793 & 1767, & IV & 3066 & 1782 & & $3486^{\prime}$ \\
\hline 1759, & I & 2815 & 1768 & II & 3092 & 1783 & I & 3503 \\
\hline 1759, & III & 2817 & 1768 & III & 3093 & 1783 & II & 3504 \\
\hline 1760 & IV & 2848 & 1768 & IV & 3094 & 1783 & III & 3505 \\
\hline 1761 , & VI & 2878 & 1769 & I & 3123 & 1783 & IV & 3506 \\
\hline 1762 & $I$ & 2903 & 1769 & II & 3124 & 1784 & I & 3528 \\
\hline 1762 , & III & 2905 & 1770 & I & 3154 & 1784 & II & 3529 \\
\hline 1762, & $\mathrm{~V}$ & 2907 & 1770 & II & 3155 & 1784, & IV & 3531 \\
\hline 1762 , & VII & 2909 & 1771, & I & 3183 & 1785 & I & 3554 \\
\hline 1763 & I & 2939 & 1771, & II & 3184 & 1785 & II & 3555 \\
\hline 1763 & III & 2941 & 1772 & I & 3213 & 1785 & III & 3556 \\
\hline 1763, & V & 2943 & 1772 & II & 3214 & 1785 & IV & 3557 \\
\hline 1764 & I & 2971 & 1773 & I & 3239 & 1786 & II & 3582 \\
\hline 1764 & II & 2972 & 1773, & II & 3240 & 1786 & III & 3583 \\
\hline 1764 , & III & 2973 & 1774 & II & 3269 & 1787 & III & 3614 \\
\hline 1764 & IV & 2974 & 1775 & I & 3293 & 1787, & IV & 3615 \\
\hline 1764, & $\mathrm{V}$ & 2975 & 1775 & II & 3294 & 1788 & I & 3641 \\
\hline 1765 , & I & 3001 & 1776, & I & 3323 & 1789 & I & 3677 \\
\hline 1765 & II & 3002 & 1776 , & II & 3324 & 1789, & II & 3678 \\
\hline 1765 & IV & 3004 & 1777 & I & 3348 & 1789, & VIII & 3684 \\
\hline 1765 & VI & 3006 & 1777 & II & 3349 & 1790, & III & 3730 \\
\hline 1766 & II & 3030 & 1778 & I & 3376 & 1790 & VII & 3734 \\
\hline 1766 , & III & 3031 & 1778 & II & 3377 & 1791, & VI & 3777 \\
\hline 1766 , & IV & 3032 & 1779 & I & 3407 & 1791, & VII & 3778 \\
\hline \multirow[t]{2}{*}{1766 , } & $\mathrm{V}$ & 3033 & 1779 , & II & 3408 & 1794, & I & 3866 \\
\hline & & & 1780 & I & 3435 & 1794, & II & 3867 \\
\hline
\end{tabular}

* 1 volume for Bengal, Surat and Ceylon 
3. Overgekomen brieven van Coromandel (Letters from Coromandel):

\begin{tabular}{|c|c|c|c|c|c|c|c|c|}
\hline ear & & K.A. & Year & & K.A. & Year & & K.A. \\
\hline 1756 , & I & 2743 & 1771, & I & 3181 & 1779, & III & 3406 \\
\hline 1762 & & 2902 & 1772 , & I & 3212 & 1780 , & I & 3432 \\
\hline 1763, & I & 2935 & 1773, & I & 3237 & 1780 & II & 3433 \\
\hline 1763, & III & 2937 & 1774 , & I & 3265 & 1780 , & III & 3434 \\
\hline 1763, & IV & 2938 & 1774, & II & 3266 & 1781, & I & 3460 \\
\hline 1764 & I & 2969 & 1774, & III & 3267 & 1781, & II & 3461 \\
\hline 1764, & II & 2970 & 1775, & I & 3291 & 1781, & III & 3462 \\
\hline 1765, & I & 2999 & 1775, & II & 3292 & 1783 & & 3502 \\
\hline 1765 & II & 3000 & 1776, & I & 3321 & 1787 & I & 3610 \\
\hline 1766 , & I & 3026 & 1776, & II & 3322 & 1787, & II & 3611 \\
\hline 1766 , & II & 3027 & 1777, & I & 3346 & 1789, & I & 3675 \\
\hline 1767 & I & 3056 & 1777 , & II & 3347 & 1790, & I & 3725 \\
\hline 1768 & I & 3089 & 1778 & $\mathrm{~J}$ & 3374 & 1791, & I & 3768 \\
\hline 1769, & I & 3121 & 1778 & II & 3375 & 1791, & II & 3769 \\
\hline 1770 , & I & 3151 & 1779, & I & 3404 & 1792 , & I & 3813 \\
\hline & & & 1779, & II & 3405 & 1794. & I & 3865 \\
\hline
\end{tabular}

4. Overgekomen brieven van Malabar (Letters from Malabar):

\begin{tabular}{|c|c|c|c|c|c|c|c|c|}
\hline Year & & K.A. & Year & & K.A. & Year & & K.A. \\
\hline 1754 & & 2707 & 1768, & I & 3097 & 1779 , & II & 3412 \\
\hline 1755 & & 2726 & 1768 & II & 3098 & 1780 & & 3440 \\
\hline 1756 & & 2749 & 1769, & I & 3128 & 1781 & & 3467 \\
\hline 1757, & I & 2769 & 1769. & II & 3129 & 1783, & I & 3509 \\
\hline 1757, & II & 2770 & 1770 , & I & 3158 & 1783 & II & 3510 \\
\hline 1758, & I & 2797 & 1770 & II & 3159 & 1784 & I & 3536 \\
\hline 1758, & II & 2798 & 1771, & I & 3187 & 1784 & II & 3537 \\
\hline 1759, & I & 2820 & 1771 , & II & 3188 & 1785, & I & 3560 \\
\hline 1759, & II & 2821 & 1772 , & I & 3217 & 1785 & II & 3561 \\
\hline 1760, & I & 2852 & 1772 & II & 3218 & 1786 & & 3587 \\
\hline 1760 , & II & 2853 & 1772 , & III & 3219 & 1787 & & 3619 \\
\hline 1761 & & 2879 & 1773 & I & 3244 & 1788 & I & 3643 \\
\hline 1762 & & 2911 & 1773, & II & 3245 & 1788 & II & 3644 \\
\hline 1763 & I & 2947 & 1774 & & 3272 & 1788 & III & 3645 \\
\hline 1763 & II & 2948 & 1775 , & I & 3297 & 1789 , & I & 3693 \\
\hline 1764 , & I & 2978 & 1775 , & II & 3298 & 1789 , & II & 3694 \\
\hline 1764 , & II & 2979 & 1775 & III & 3299 & 1789, & III & 3695 \\
\hline 1765 , & I & 3007 & 1776 & I & 3327 & 1790 & I & 3741 \\
\hline 1765 , & II & 3008 & 1776 , & II & 3328 & 1790 & II & 3742 \\
\hline 1766 , & I & 3037 & 1777. & I & 3352 & 1790 & III & 3743 \\
\hline 1766, & II & 3038 & 1777 & II & 3353 & 1791, & I & 3787 \\
\hline 1766, & III & 3039 & 1778 & I & 3380 & 1791, & II & 3788 \\
\hline 1767 , & I & 3069 & 1778 & II & 3381 & 1792, & I & 3821 \\
\hline 1767 & II & 3070 & 1779, & I & 3411 & 1794 & I & 3871 \\
\hline
\end{tabular}


5. Overgekomen brieven van Bengalen (Letters from Bengal):

\begin{tabular}{|c|c|c|c|c|c|c|c|}
\hline Year & & K.A. & Year & K.A. & Year & & K.A. \\
\hline & & 3428 & 1782 & 3486 & 17 & II & 3552 \\
\hline 1781, & I & 3456 & 178.3 & 3502 & 1788 & I & 3637 \\
\hline 178 & II & 3457 & 1785 , & I 3551 & & & \\
\hline
\end{tabular}

6. Secret resolutions Governor-General and Councillors:

1756-1791, 8 volumes, K.A. 736-43.

7. Resolutions Governor-General and Councillors:

Year K.A.

\begin{tabular}{ll}
\hline 1766 & 696 \\
1769 & 699 \\
1774 & 704 \\
1782 & 712
\end{tabular}

8. Brieven Heren XVII (Letters from The Seventeen to Batavia):

Period

K.A.

30 March 1751-21 March 1757

2 vols. $470-1$.

25 March 1762-21 April 1769

2 vols. $473-4$.

8 October $1774-31$ May 1791

5 vols. $476-80$.

9. Other K.A.-numbers consulted:

4460. This volume contains correspondence of the Secret Committee for War Affairs set up by The Seventeen on 12 February 1781.

$4464 \mathrm{BB}$. Loose papers of the Amsterdam Chamber. Here may be found the proposals for a treaty which Iroelappa delivered in September 1780 (comp. p. 105 supra).

$4464 \mathrm{R} / \mathrm{S}$. This volume contains papers of the Committee Sale Malabar.

10. Hooge Regeering Batavia.

This is a collection of papers which were transferred from Batavia to the General State Archives during the years 1862 and 1863. An inventory in typescript composed by Mrs. M. A. P. Meilink-Roelofsz is in the Archives. The volumes mainly refer to the High Government's administration of the settlements outside Java.

The following numbers have been consulted:

36, 308-11, 316-8, 337, 589, 669, 739, 754 and 783. 


\section{B. India Office}

\section{Rengal Foreign Consultations:}

Vols. 1 and 2 (Range 165, vols. 41 and 42) contain papers on Dutch affairs in 1781 and 1782 .

2. Bengal Secret and Military Consultations:

Range A, vols. 56, 59 and 60 in connection with the relations between the English and the Dutch Companies in 1780 and 1781.

3. Bombay Abstract Letters Received:

Vol. 2 for the period 1762-1768.

Vol. 3 for the period $1767-1783$.

4. Letters Received From Bombay:

Vol. 3 for the period 22 December 1771-30 December 1772.

Vol. 4 for the period 8 January 1773-5 April 1776.

5. Madras Select Committee Consultations:

Range D, vols. 3 and 5 of the 2 nd series starting 10 May 1780 have been used in connection with the negotiations of $1780-81$.

6. Factory Records Anjengo:

No. 5 for the period 1 January 1785-30 December 1787 (previous classification: Range 430, no. 79).

No. 6 for the period 1 January 1788-30 December 1789 (previous classification: Range 430, no. 80 ).

7. Factory' Records Tellicherry:

No. 7 for the period 1 January 1787-31 December 1788 (previous classification: Range 431, no. 3 ).

No. 8 for the period 1 January 1789-31 December 1790 (previous classification: Range 431, no. 4).

8. Home Miscellaneous Series:

Nos. $84,108,122,145,151-2,156-7,161,167,190,248,308$, $316,322,567$ and 614 . 


\section{India Orfice Library}

1. Mackenzie Collection: Private:

Nos. $34,47,50,55,57$ and 60 .

2. The Orme Collection:

a. Orme MSS, O.V.:

Nos. 26, 33, 72, 92 and 134.

b. Orme MSS, India :

No. I.

3. Minor Collections:

Nos. 99-101, 136, 220, 291, 457 and 776.

No. 776 contains the Journal of admiral Hughes from 21 December 1780 to 29 January 1783 .

\section{Bodleian Library}

1. M.S. Eng. hist. c. 83-7.

These five volumes have been consulted in connection with the events in Coromandel in 1781. 
III. PUBLISHED RECORDS

A. Selections from the Records of the Madras Government, Dutch Records:

No. 1. "Memoir on the Malabar Coast by J. V. Stein van Gollenesse. Composed in the year 1743 A.D.". Madras, 1908.

No. 2. "Memoir written in the year 1781 A.D. by Adriaan Moens, Extraordinary member of the Batavia Council, Governor and Director of the Malabar Coast, Canara and Vingurla, for his successor". Madras, 1908.

No. 3. "Memoir of Commander Frederik Cunes delivered to his successor Caspar de Jong on the 31st December 1756". Madras, 1908.

No. 4. "Memoir of Johan Gerard van Angelbeek Ordinary member of the Council of Dutch India and Governor-elect of Ceylon delivered to his successor in the administration of Malabar Jan Lambertus van Spall in the year 1793". Madras, 1908.

No. 5. "Historical Account of Nawab Hyder Ali Khan". Madras, 1908.

It seems to me that this document, dealing with the events from 1763 onwards, was especially compiled in 1774 for Moens after he had discovered that the presents of 1767 had never been sent to Haidar.

No. 7. "Memoir of the departing Commander Cornelius Breekpot delivered to his successor the worshipful titular Governor and Director-elect Christian Lodewijk Senff on the last day of February 1769". Madras, 1909.

No. 11. "Memoir of Commandeur Caspar de Jong delivered to his successor Godefridus Weyerman dated 7th March 1761". Madras, 1910.

No. 12. "Memoir of Commandeur Godefridus Weyerman delivered to his successor Carnelis Breekpot on the 22nd February 1765”. Madras, 1910. 
No. 13. "The Dutch in Malabar", being a translation of Selections Nos. 1 and 2 with introduction and notes by A. Galletti, A. J. van der Burg and P. Groot. Madras, 1911.

B. Selections from the Dutch Records of the Ceylon Government:

No. 4. "Memoir of Joan Gideon Loten Governor of Ceylon delivered to his successor Jan Schreuder on February 28, 1757'. Colombo, 1935.

No. 5. "Memoir of Jan Schreuder Governor of Ceylon delivered to his successor Lubbert Jan Baron van Eck on March 17, 1762". Colombo, 1946.

C. Other Published Records:

Aitchison, C. U., ed., A Collection of Treaties, Engagements and Sanads relating to India and Neighbouring Countries. Vols. IX and X. Calcutta, 1929-30.

Calendar of Persian Correspondence. Being Letters which passed between some of the Company's Servants and Indian Rulers and Notables. Vol. VI, 1781-5. Delhi, 1938.

Dam, Pieter van, Beschryvinge van de Oostindische Compagnie. Tweede boek, deel II, and Derde boek, ed. F. W. Stapel. 's-Gravenhage, 1932 and 1943

Deventer, M. L. van, ed., De opkomst van het Nederlandsch gezag in Oost-Indie. Vol. XI. 's-Gravenhage, 1883.

Forrest, G. W., ed., Selections from the Letters, Despatches, and other State Papers preserved in the Bombay Secretariat. Home Series, vol. II. Bombay, 1887.

Forrest, G. W., ed., Selections from the Letters, Despatches, and other State Papers preserved in the Foreign Department of the Government of India. 1772-1785. 3 vols. Calcutta, 1890.

Forrest, G., ed., Selections from the State Papers of the GovernorsGeneral of India. Lord Cornwallis. 2 vols. Oxford, 1926.

Gense, J. H. and Banaji, D. R., ed., The Third English Embassy to Poona. Bombay, 1934.

Heeres, J. E., ed., Corpus Diplomaticum Neerlando-Indicum. Vols. I and II. Bijdragen tot de Taal-, Land-en Volkenkunde van Nederlandsch-Indië, 57 and 87. 's-Gravenhage, 1907 and 1931.

Jonge, J. K. J. DE, ed., De opkomst van het Nederlandsch gezag in Oost-Indï. Vols. VI and VIII. 's-Gravenhage, 1872 and 1875. 
KIrkpatrick, W., ed., Select Letters of Tippoo Sultan to various public Functionaries. London, 1811.

Kirkpatrick, W., "Original Letters of Tippoo Sultaun". The Asiatic Annual Register, XII, 1810-11, pp. 385-403. London, 1812.

Logan, W., ed., A Collection of Treaties, Engagements and other Papers of Importance relating to British Affairs in Malabar. 2nd ed. Madras, 1891.

MiJer, P., ed., Verzameling van Instructïn, Ordonnanciën en Reglementen voor de Regering van Nederlandsch Indië. Batavia, 1848.

Ray, N. B., ed., English Records of Maratha History, Poona Residency Correspondence, vol. 3, "The Allies' War with Tipu Sultan 1790-1793”. Bombay, 1937.

Stapel, F. W., ed., Corpus Diplomaticum Neerlando-Indicum. Vols. III-V. Bijdragen tot de Taal-, Land-en Volkenkunde van Nederlandsch-Indie, 91, 93 and 96. 's-Gravenhage, 1934, 1935 and 1938. 
IV. CORRESPONDENCE AND NARRATIVES OF PARTICIPANTS IN EVENTS

Couteur, J. LE, Letters chiefly from India. London, 1790.

Davies, C. Collin, ed., The private Correspondence of Lord Macartney. London, 1950.

Dirom, Major, $A$ Narrative of the Campaign in India, which terminated the War with Tippoo Sultan, in 1792. 2nd ed. London, 1794.

DruRy, H., ed., Letters from Malabar by Jacob Canter Visscher, now first translated from the original Dutch. Madras, 1862.

Forster, E. M., ed., Original Letters from India (1779-1815). Mrs Eliza Fay. London, 1925.

Fullarton, W., A View of the English Interests in India; and an Account of the military Operations in the southern Parts of the Peninsula, during the Campaigns of 1782, 1783, and 1784. In two Letters addressed to the Right Honourable the Earl of ... and to Lord Macartney and the Select Committee of Fort St. George. 2nd ed. London, 1788.

GRIER, S. C., The Letters of Warren Hastings to his Wife. Edinburgh, 1905.

Lawrence, A. W., ed., Captives of Tipu. Survivors' Narratives. London, 1929.

Moor, E., A Narrative of the Operations of Captain Little's Detachment. London, 1794.

Munro, InNes, $A$ Narrative of the military Operations on the Coast, against the combined Forces of the French, Dutch, and Hyder Ally Cawn, from the year 1780 to the Peace in 1784; In a Series of Letters. London, 1789.

Philips, C. H., ed., The Correspondence of David Scott, Director and Chairman of the East India Company relating to Indian Affairs. 1787-1805. Vol. I. London, 1951. 


\section{OTHER WORKS}

Aalbers, J., Rijcklof van Goens, Commissaris en veldoverste der OostIndische Compagnie, en zijn arbeidsveld, 1653/54 en 1657/58. Groningen, 1916.

Abdul Ali, A. F. M., "The Failure of Tipu Sultan”, Bengal Past $\mathcal{E}$ Present, LVIII, pp. 64-70. Calcutta, 1940.

Aiyar, R. Sathyanatha, History of the Nayaks of Madura. Oxford Univ. Press, 1924.

Alexander, P. C., The Dutch in Malabar. Annamalainagar, 1946.

Baldaeus, Ph., A Description of the East India Coasts of Malabar and Cormandel. Vol. 3 of A. and J. Churchill's $A$ Collection of Voyages and Travels. London, 1704.

BAQAI, I. H., “The Death of Haidar Ali”, Islamic Culture, XXI, pp. 167-71. Hyderabad, 1947.

BARTstra, J. S., Vlootherstel en legeraugmentatie 1770-1780. Assen, 1952.

Bhattacharya, S., The East India Company and the Economy of Bengal from 1704 to 1740. London, 1954.

Bowring, L. B., Haidar Ali and Tipu Sultan. Oxford, 1899.

Brown, C. P., ed., Memoirs of Hyder and Tippoo, Rulers of Seringapatam, written in the Mahratta language by Ram Chandra Rao. Madras, 1849.

Bruce, H., Letters from Malabar and on the Way. London, 1909.

Buchanan, F., A Journey from Madras through the Countries of Mysore, Canara, and Malabar. 3 vols. London, 1807.

Busteed, H. E., Echoes from Old Calcutta. 4th ed. London, 1908.

Caldwell, R., A political and general History of the District of Tinnevelly. Madras, 1881.

Clark, G. N. and W. J. M. van Eysinga, The Colonial Conferences between England and the Netherlands in 1613 and 1615. Part II. Leiden, 1951.

Colenbrander, H. T., De patriottentijd. Vols. 1 and 3. Den Haag, 1897-9. 
Dasgupta, A. P., The Central Authority in British India 1774-1784. Calcutta, 1931.

Datta, K., "The Malabar Rajahs and the East India Company", Bengal Past \& Present, LVII, pp. 1-9. Calcutta, 1939.

DatTA, K., “A proposed Anglo-Dutch Treaty, 1780 81", The Journal of the United Provinces Historical Society, XIV, pp. 118-24. Allahabad, 1941.

DattA, K., "Calcutta-Batavia Correspondence regarding the restoration of Dutch Settlements in India, 1784", Bharata-Kaumudi (Work in honour of R. K. Mookerji), I, pp. 227-33. Allahabad, 1945.

Datta, K., The Dutch in Bengal and Bihar, 1740-1825 A.D. Patna, 1948.

Day, F., The Land of the Permauls, or Cochin, its Past and its Present. Madras, 1863.

Dodwell, H. H., "Warren Hastings and the Assignment of the Carnatic", The English Historical Review, 40, pp. 375-96. London, 1925.

Dodwell, H. H., “The Carnatic, 1761-84", The Cambridge History of the British Empire, IV, pp. 273-94. Cambridge, 1929.

Dodwell, H. H., “Tippu Sultan”, Great Men of India, ed. by L. F. Rushbrook Williams, pp. 210-9. (The Home Library Club, 1941).

Duncan, J., "Historical Remarks on the Coast of Malabar with some Description of the Manners of its Inhabitants", Asiatic Researches, 5, pp. 1-36. London, 1799.

Feiling, K., Warren Hastings. London, 1954.

Foster, W., "The East India Company, 1600-1740", The Cambridge History of the British Empire, IV, pp. 76-116. Cambridge, 1929.

Foster, W., England's Quest of Eastern Trade. London, 1933.

Furber, H., Henry Dundas. First Viscount Melville. 1742-1811. London, 1931.

Furber, H., John Company at Work. Cambridge (Mass.), 1948.

GEYL, P., "The Dutch in India", The Cambridge History of the British Empire, IV, pp. 28-60. Cambridge, 1929.

Glamann, K., “The Dutch East India Company's Trade in Japanese Copper, 1645-1736”, The Scandinavian Economic History Review, I, pp. 41-79. København, 1953.

GLEIG, G. R., Memoirs of the Life of the Right Hon. Warren Hastings, first Governor-General of Bengal. Vol. II. London, 1841. 
Godee Molsbergen, E. C., De Nederl. Oostindische Compagnie in de achttiende eeuw. This is vol. IV of the Geschiedenis van Nederlandsch Indië, ed. by F. W. Stapel. Amsterdam, 1939.

GrAAF, H. J. DE, Geschiedenis van Indonesië. 's-Gravenhage, 1949.

Gijsberti Hodenpijl, A. K. A., "Gustaaf Willem Baron van Imhoff als Gouverneur van Ceylon. 1736-1740", Bijdragen tot de TaalLand-en Volkenkunde van Nederlandsch-Indië, 75, pp. 481-625. 's-Gravenhage, 1919.

Gijsberti Hodenpijl, A. K. A., "De Nederlandsche bezittingen op de kust van Koromandel in 1780 en 1781", De Indische Gids, 44, pp. 332-49. Amsterdam, 1922.

Gijsberti Hodenpijl, A. K. A., "De Gouverneurs van Koromandel: Christiaan van Teylingen (1761-1765) en Pieter Haksteen (17651771)", Bijdragen voor Vaderlandsche Geschiedenis en Oudheidkunde, 5e reeks, 10e deel, pp. 134 -56, 257-76, 6e reeks, 2e deel, pp. 109-22, 6e reeks, 3e deel, pp. 281-99. 's-Gravenhage, 1923, $1925,1926$.

HAAFNER, J., Lotgevallen op eene reize van Madras over Tranquebaar naar het eiland Ceilon. Haarlem, 1806.

HAAfNer, J., Reize in eenen palanquin. 2 vols. Amsterdam, 1808.

HAAFNER, J., Reize naar Bengalen en terugreize naar Europa. Ed. by C. M. Haafner. Amsterdam, 1822.

Havart, D., Op-en ondergang van Cormandel. Amsterdam, 1693.

HeEres, J. E., “De "Consideratiën" van van Imhoff”, Bijdragen tot de Taal-, Land- en Volkenkunde van Nederlandsch-Indië, 66, pp. 441-621. 's-Gravenhage, 1912.

Horst, W. A., "De peperhandel van de Vereenigde Oost-Indische Compagnie”, Bijdragen zoor Vaderlandsche Geschiedenis en Oudheidkunde, 8e reeks, 3e deel, pp. 95-103. 's-Gravenhage, 1942.

Hosten, R. P. H., “Les Registres de l'église de Chandernagor (16901818)", Revue historique de l'Inde française, 3, pp. 97-166. Pondichéry, 1919.

Iongh, D. DE, Het krijgswezen onder de Oostindische Compagnie. Den Haag, 1950.

Jonge, J. C. DE, Het Nederlandsche zeewezen. Vol. IV. 2nd ed. Haarlem, 1861.

KalfF, S., "Een verloren "buitencomptoir" der O.I. Comp.", De Indische Gids, 24, pp. 862-77, 1005-21. Amsterdam, 1902.

Kampen, N. G. van, Geschiedenis der Nederlanders buiten Europa. 3 vols. Haarlem, 1831-3. 
Khan, M. H., History of Tipu Sultan. Calcutta, 1951.

KincaId, C., "Haidar Ali", Great Men of India, ed. by L. F. Rushbrook Williams, pp. 198-209. (The Home Library Club, 1941).

Kirmani, M. H. A. K., The History of Hydur Naik. Transl. from the Persian by W. Miles. London, 1842 .

Kirmani, M. H. A. K., The History of the Reign of Tipu Sultan. Transl. from the Persian by W. Miles. London, 1864.

KLerk De Reus, G. C., "De vermeestering van Chinsura in 1781 en 1795", Verhandelingen van het Bataviaasch Genootschap van Kunsten en Wetenschappen, XXXVIII. Batavia, 1875.

KRIShNA, BaL, Commercial Relations between India and England (1601 to 1757). London, 1924.

KRIShNA, BAL, "The Rise and Fall of the Dutch in India", Bengal Past \& Present, LVI, pp. 98-106. Calcutta, 1939.

KRIShNA, M. H., "The Dalavai Family of Mysore", Bharata Kaumudi, I, pp. 347-67. Allahabad, 1945.

Krom, N. J. Gouverneur Generaal Gustaaf Willem van Imhoff. Amsterdam, 1941.

L., C. A., British and Native Cochin. Cochin, 1860.

LAUTs, G., Geschiedenis van de vestiging, uitbreiding, bloei en verval van de magt der Nederlanders in Indië. Vols. 2-4. Amsterdam, $1856-9$.

Lehuraux, A., "Rustum Jung (Chevalier de Lalée). A French Leader of Basalat Jung, Haider-Ali, and Tipu-Sultan", Journal Royal Asiatic Society, 1956, pp. 125-41. London, 1956.

LOGAN, W., Malabar. 2 vols. Madras, 1887.

Mackenzie, R., $A$ Sketch of the War with Tippoo Sultaun. 2 vols. Calcutta, $1793-4$.

Mac Leod, N., "De Oost-Indische Compagnie op het vasteland van Azie in de laatste jaren der 17e eeuw", De Indische Gids, 24, pp. 1304 -17. Amsterdam, 1902.

Mac Leod, N., "Uit de Geschiedenis der Oost-Indische Compagnie in de tweede helft der 18e eeuw", De Indische Gids, 32, pp. 620-30, 761-77, 1492-1506, 1605-21. Amsterdam, 1910.

Mac Leod, N., "De machtsuitbreiding der Oost-Indische Compagnie op het vasteland van Azië, van 1683-1697", De Indische Gids, 23, pp. $1149-68,1271-86 ; 24$, pp. 254-72, 584-99. Amsterdam, 1919-20. 
Malleson, G. B., Final French Struggles in India and on the Indian Seas. London, 1884.

Martineau, A., Bussy et l'Inde française 1720-1785. Paris, 1935.

Mayer, A. C., Land and Society in Malabar. Bombay, 1952.

Memoirs of the late War in Asia, by an Officer of Colonel Baillie's Detachment. 2 vols. London, 1788.

Menon, K. P. Padmanabha, History of Kerala. Written in the form of Notes on Visscher's Letters from Malabar. Ed. by T. K. Krishna Menon. 4 vols. Ernakulam, $1924-37$.

Michaud, J., Histoire des progrès et de la chûte de l'Empire de Mysore sous les règnes d'Hyder-Aly et Tippoo-Saib. 2 vols. Paris, 1801-9.

MıLo, T. H., De invloed van de zeemacht op de geschiedenis der Vereenigde Oost-Indische Compagnie. Den Haag, 1946.

Moreland, W. H., From Akbar to Aurangzeb. London, 1923.

Moreland, W. H., Relations of Golconda in the early seventeenth Century. London, 1931.

Moreland, W. H. and A. C. Chatterjee, A Short History of India. 2nd ed. London, 1945.

NAmbiaR, O. K., "The Mysore Navy", The Half-Yearly Journal of the Mysore University, New Series, Section A-Arts, VIII, No. 2, March 1948, pp. 71-95.

Nederlandsch India, in haaren tegenwoordigen toestand beschouwd. Batavia, 1780.

Panikkar, K. M., Malabar and the Dutch. Bombay, 1931.

Poonen, T. I., A Survey of the Rise of the Dutch Power in Malabar (1603-78). Trichinopoly, 1948.

Rao, C. Hayavadana, History of Mysore (1399-1799 A.D.). 3 vols. Bangalore, 1943-8.

REA, A., Monumental Remains of the Dutch East India Company in the Presidency of Madras. Archaeological Survey of India. New Imp. Series, XXV. Madras, 1897.

Richmond, H., The Navy in India 1763-1783. London, 1931.

Rosson, F., The Life of Hyder Ally. London, 1786.

Roelofsz, M. A. P., De vestiging der Nederlanders ter Kuste Malabar. Verhandelingen van het Koninklijk Instituut voor de Taal-, Landen Volkenkunde van Nederlandsch-Indië, 4. 's-Gravenhage, 1943.

Sarkar, J., "Haidar Ali's Invasion of the Eastern Carnatic, 1780", Islamic Culture, 15, pp. 217-28. Hyderabad, 1941. 
Sastri, K. A. Nilakanta, History of India, vol. III. Madras, 1952.

SEN, S., Studies in Indian History. Calcutta, 1930.

Sen, S. P., The French in India. First Establishment and Struggle. Calcutta, 1947.

Sen, S. P., "Franco-Mysore Relations (1785-93)", Proceedings Indian Historical Records Commission, XXXI, part II, Mysore, January 1955, pp. 32-9. Delhi, n.d.

Sinha, N. K., Haidar Ali. 2nd ed. Calcutta, 1949.

Srinivasachari, C. S., "A Note on the Genesis of the War with Tippu in 1789", Journal of Indian History, XXVI, 1948, pp. 269-73. Trivandrum, 1949.

Srinivasan, V., "The Dutch in India", Journal of Indian History, XI, 1932, pp. 41-62. Madras, 1933.

Stapel, F. W., Geschiedenis van Nederlandsch Indië. Vol. III. Amsterdam, 1939.

Stapel, F. W., Geschiedenis van Nederlandsch-Indï̈. 2nd ed. Amsterdam, 1943.

Stavorinus, J. S., Reize van Zeeland over de Kaap de Goede Hoop naar Batavia, Bantam, Bengalen, ens. gedaan in de jaaren 1768 tot 1771. 2 vols. Leyden, 1793.

Stavorinus, J. S., Voyages to the East Indies. Transl. from the Dutch by S. H. Wilcocke. Vol. III. London, 1798.

Stewart, C., Memoirs of Hyder Aly Khan and his son Tippoo Sultan. In Descriptive Catalogue of the Oriental Library of the late Tippoo Sultan of Mysore. Cambridge, 1809.

Swaminathan, K. D., The Nayakas of Ikkeri. Madras, 1957.

Terpstra, H., De vestiging van de Nederlanders aan de Kust van Koromandel. Groningen, 1911.

Terpstra, H., "De Nederlanders in Voor-Indië bij de stichting van het fort Geldria te Paliacatta", De Indische Gids, 37, pp. 331-60. Amsterdam, 1915.

Terpstra, H., De Nederlanders in Voor-Indië. Amsterdam, 1947.

T(OUR), M. M. D(E) L(A), The History of Hyder Shah, alias Hyder Ali Khan Bahadur: and of his son, Tippoo Sultaun. Rev. ed. London, 1855.

Valentijn, F., Oud en Nieuze Oost-Indië. Vol. V. Dordrecht-Amsterdam, 1726. 
Vlekke, B. H. M., Nusantara. A History of the East Indian Archipelago. 3rd printing. Cambridge (Mass.), 1945.

Voorbeytel Cannenburg, W., "De eerste expeditie van 's Lands Zeemacht naar Oost-Indië", 9e Jaarverslag Vereeniging Nederlandsch Historisch Scheepvaart Museum, Bijl. D, pp. 95-109. Amsterdam, 1925.

Wilks, M., Historical Sketches of the South of India. 3 vols. London, $1810-7$.

Wilson, W. J., History of the Madras Army. Vol. 2. Madras, 1882.

Wright, A. and W. L. Sclater, Sterne's Eliza. Some Account of her Life in India: with her Letters written between 1757 and 1774. London, 1922.

Wylly, H. C., A Life of Lieutenant-General Sir Eyre Coote, K. B. Oxford, 1922. 


\section{INDGX}

\section{A}

Abdul Qadir Khan, 149, 155-7.

Abu Muhammad Mirdah, 131.

Accama, 107, 113.

Achin, 2.

Alexander, VII, 14n., 84n., 100, 152-3, 164, 166-7.

Ali Raja, 24-6, 29-30, 39, 48, 52, 64-5, 68-9, 72, 76, 84, 86, 97, 172.

Ali Zaman Khan, 40-1, 43, 89n.

Alting, 107-8n., 126.

Anda Setty, 151.

Anjengo, 18.

Arabia, 15, 142n.

Arcot, 17, 19, 24n., 28, 40, 66, 106, 131.

Arshed Beg Khan, 134, 136-40.

Aurangzeb, 17.

Ayacottah, 96, 126-8, 142, 146-7, 149-55, 157-8.

\section{B}

Bahmani sultanate, 5 .

Bantam, 2, 4n., 8-9, 15, 18.

Bartstra, 125.

Basalat Jang, 20n.

Basrur, 23, 27, 41, 44.

Batavia, VII, 8-9, 14, 21-3, 25-8, 32-8, $41,43,46-7,51,53,55-61,63,65,67$ n.9, 72-3, 82, 84-5, 90-1, 93, 95-6, 98-101, $103-5,107-8,111,113,115,120,124$, $126,135,138,141-4,146-53,161,165-6$, 182.

Bednur, 23-5, 29.

Bengal, 1, 3, 13, 16, 19, 107, 109, 124.

Beypore, 44, 74.

Bijapur, 5, 10, 16-7.

Bird, 110.

Blaaukamer, 111n.

Bombay, 18, 34-5, 86, 94n., 128, 159, 165.

Braithwaite, 119n.

Breekpot 25-9, 31-3, 36-8, 40-51, 53-7, 59-69, 84-5, 100-1, 111, 173-4n.

Brouwer, $15 \mathrm{n}$.
C

Calcutta, 1, 18, 34n., 108-11, 160-1, 169.

Calicut, 29, 31-3, 38-42, 44-5, 47-51, 60, $62-4,74-6,78-83,88-90,93,97-8,101$, $105,126,128,133-4,136-41,144-5$, 171-5, 177-8.

Calicut, Zamorin of, 9-10, 12-4, 22, 25, 28-9, 31-2, 37-9, 42, 44-7, 60-2, 64-5, $72-80,83,95-8,133-4,144,147-8 n$., $158 \mathrm{n} ., 171-4,177-8$.

Cannanore, 9, 12, 23-5, 27-30, 57-8, 68-72, 84-6.

Canter Visscher, 165.

Carnatic, 5-6, 17, 20, 66, 103-4, 111.

Cellarius, 133.

Chanda Sahib, 24n.

Chandra Rao, 77-80.

Cherttala, 77.

Chetvai, 31, 39, 47, 58, 68, 76, 78, 80, 82, $88,90,95-9,101-2,108,121,126,128-9$, 133-7, 139, 142, 147, 152.

China, 3, 19.

Chinsurah, 107.

Chirakkal, 30.

Chittur, 130.

Chowghat, 42, 45, 77-8, 172.

Cochin, 9, 12, 21-4, 26-9, 31, 33, 35-6n., $38-9,41-9,51,56-7,60,63,71-3,76$, $78-82,84-5,90,93,96-7,100,103,108-$ $9,119-20,122,126-8,130-1,133,136-$ $7,139,141-2,144-7,149,151-6,158-$ $61,165,169,171-3,175$.

Cochin, raja of, 10, 13-4, 22, 31-2, 37-8, $41-8,50-1,60,68,71 n .-6,79-80,83-4 n$., $90,92-102,112,119,128,135,144,146$, $148-9,154-5,159-62,164,171,173$.

Coimbatore, 52, 60, 133, 148, 171-7.

Colombo, 8, 21, 27, 33, 37n.-8, 44, 56, 63, $96,109,122-4,126-7,130,133,136$, $149,169$.

Coorg, 73-4, 76, 83, 91, 177-9.

Coote, 108-10, 112, 119n., 134.

Cornwallis, 160-1.

Cranganore, VIII, 12, 39, 41, 48, 58, 68, 
$70,76-80,95-7,102-3,111,120,126-9$, $133,142,144,146-59,172-3$.

Cranganore, raja of, 48, 76-80, 89, 92-5, $102,112,156,164$.

Cranganore river, 94, 159.

Cuddalore, 132, 162.

\section{D}

Daimichen, 45-6, 173.

d'Almeida, 145.

Danes, 105-6, 145, 162.

Dasgupta, 109.

Datta, 169n.

Day, English resident at Calicut, 40, 42-3.

Day, F., VII, 14n., 100.

de Bussy, 140.

de Klerk, 108.

de Neijs, 106.

de Riberto, 82-3, 88-90, 98.

de Saint Etienne, 45-6, 173.

de Souza, 23, 25.

de Suffren, 122n., 129.

dc la Tour, 171-2, 174-5.

Delhi sultanate, 5 .

Dellawa, 31, 47, 102, 128-9, 147-9n.

Dharmapatam, river of, 30-1.

Dighton, 110.

Diu, 9.

Dormieux, 182.

Duprat, 74-5.

E

Ebell, 123n.-4, 126, 131.

English, 1-3, 6, 10-2, 16-20, 24n., 27-8, $30,32,34-6,40 \mathrm{n} ., 42-3,45-7,51-2$, $54-6,61-3,65-9,71,75,83,86,91-2$, $94,97,103-4,106-10,112,114-21,126-$ $36,140-5,147-9,151,153-4,157,159-$ 62, 164-6, 168-70, 180-2, 189.

\section{$\mathbf{F}$}

Falck, 29, 33-8, 53-7, 59-66, 94, 96, 103-4. $107-11,114-5,118-24,126,130-4,140-$ $1,168$.

Formosa, 3, 12.

French, 1, 16-7, 19-20, 24n., 35, 43, 55, $62,66,74-5,103,121-2,124-5,127$, $129-30,133,140,145,149$ n., 160, 170, 181.
Frenchmen in Mysorean service, 25, 56, 91, 129, 139.

Fullarton, 133.

Furber, 151-2.

G

Gallctti, 112n.

Geeke, 113, 115, 117-8, 122-4, 126, 131.

Gingi, 5-6.

Goa, 8-10, 25, 166, 171.

Golconda, 4-5, 7, 16-7, 19.

$\mathrm{H}$

Haidar Ali, 1, 20-109, 111-24, 126-36, $141,144,154,163,167-8,171-5,177-8$, $180-2,191$.

Haidros Kutti, 76-7, 93, 97, 133.

Haksteen, 52, 54, 63, 65-6.

Hartley, 159.

Hastings, 107-8, 110-1, 114, 134, 169.

Hasz, 122-3, 130-2.

Huddleston, 109-11.

Hughes, 86, 116, 128, 190.

Humberstone, 127-8.

Hyderabad, 1, 17, 19-20.

I

Jkkeri, 23.

Indo-China, 3.

Iroelappa, 105-6, 188.

J

Jaffna, 8, 27, 63, 71, 107.

Japan, 3, 15-6.

Java, 2, 8, 15, 25n., 54-5, 101, 125.

K

Kadattanad, 24n., 31, 37, 48, 52, 61, 64-5, 76, 172, 178n.

Kanara, 20, 23-6, 54, 57, 86, 133, 177.

Kandy, 8, 26, 34n., 37.

Karikal, 116.

Karim Sahib, 130, 138.

Kayankulam, 11, 43.

Khan, VII, 152-5.

Kirmani, 158n., 171.

Kistna, 5.

Knox, 157.

Koks, 116.

Kolattiri, 13, 24, 26, 28-31, 37, 40, 45-8, $61,64,69,97,171-2$. 
Kottayam, 24n., 37, 48, 52, 61, 64, 76, 78, $172,178$.

Krishna Rao, 131.

Kroonenberg, 28-31, 33, 37, 57, 64.

Kuttur, 117.

$\mathbf{L}$

La Beaume, 34-8, 55-6, 60, 62-3, 65.

Lala Chubeela Ram, 106, 112.

Lallée, 129, 139-40n.

Le Couteur, 129n.

Light, 108-11.

Logan, VII, 49n.

\section{M}

MacLeod, 129.

Macartney, 116, 119, 127, 134.

Macassar, 15.

Madanna, 43, 48, 52, 60-5, 71, 81, 172-6.

Madras, VII, 18, 104, 106, 108-12, 114, $129,131,149,160,169 \mathrm{n}$.

Madura, 5, 9, 12, 17, 21, 35, 40n., 53, 66, 103-4, 110n.-1.

Mahé, 31, 74, 140, 145.

Mahi river, 31.

Malacca, 8, 11, 126.

Malay Archipelago, 2, 6, 10-2, 15, 18, 55, 125.

Malet, 161 .

Manar, 8-9, 34n.

Mangalore, 23-4, 28-9, 128n., 133, 136n., $151 n$.

Mannargudi, 116.

Mannarkat, 172.

Marathas, 1, 16-7, 19-20, 25-6, 60, 62-3, $69,71,73,81,94,96,101-2,104,134$, $141,143,153$.

Martanda-Varma, 14, 164 .

Masulipatam, 3-5, 7.

Mataram, 8, 15.

Mehdi Ali Khan, 89-90, 94.

Menon, 165n.

Mir Faizulla Khan, 67n.

Mocha, 165.

Mocns, 72-83, 88, 90-104, 108, 111-2, 154-5, 178, 191.

Mogul empire, 1, 3-7, 9, 16-7, 19, 52.

Moluccas, $8,15,17-8$.

Moplahs, 24, 127, 142, 171.

Mossel, Governor of Coromandel, 21.

Mossel, deputy of van Vlissingen, 117.
Most.'n, 177.

Muhammad Ali, 20-1, 24n., 32, 34-5, 40$1,44-7,52-4,56-7,63-7,75,91,94$, 97, 103-4, 108-11, 119, 128, 169.

Muhammad Yusuf Khan, 40n.

Munro, Sir Hector, 116-8.

Munro, Innes, 119.

Nagore, 94, 109, 116-8, 181.

Nairs, 30-1, 48-9, 52, 61, 64-5, 75-6, 79, $88,101,105,127,142,171-6$.

Negapatam, 5, 8, 21, 27, 44, 52, 56, 66, $89-90,93-4,105-7,109,112-3,115-23$, $126,131,134,144,168$ n., 180-2.

Nileshwar, 30.

Nixon, $116-7 \mathrm{n}$.

Nizam Ali, 1, 20, 52, 56, 60, 62-3, 96, 141.

Nizampatam, 5.

\section{$\mathbf{P}$}

Paddock, 159.

Palamcottah, 108.

Palghat, 31n., 43, 64, 72, 74, 126, 128-30, $133,146,148,152-3,171-2,177-8$.

Paliaporte, 159.

Paljetter, VIII, 31, 39, 42, 46-7, 71, 73, 79, 102-3, 127.

Panikkar, VII, 152-3.

Paponetty, 76, 95-8, 102, 108, 121, 126, $133-7,139,142,147$.

Paravur, 44, 74, 157, 172.

Prixoto, 176.

Persia, 10-1, 13, 16, 165.

Pitt, 134.

Piveron de Morlat, 130-2.

Pondicherry, 19-20, 27, 144n., 149n

Ponnani, 29, 31, 39, 41-4, 48, 60, 74, 78, $81,129-30,133,171-3$.

Poonen, 167n.

Porakad, 43.

Porto Novo, 6, 105, 162-3.

Portuguese, 1-2, 4-6, 8-13, 19, 25, 43, 154 n., 156, 161n., 165-6.

Powney, 157, 160-1n.

Pulicat, 3-4, 6, 21, 106, 114, 162.

\section{Q}

Quilandi, 48.

Quilon, 12, 58, 68, 154. 
$\mathrm{R}$

Rama-Varma, 14, 31, 34, 44-8, 50n.-4, 56, 60-1, 70-1, 75-6, 80, 92, 94-5, 97, $99-100,102,119-20,127-8,130,141$ n.60, 171-3.

Rao, Hayazadana, VII, 23n., 40n., 52n., 78n., 105n., 158n., 167, 171-4, 177-8.

Raza Ali Khan, 24n., 27-30, 34-5, 37, 40, $42,44,51-2,56,64,172$.

Red Sea, 3, 18.

Rhabbij, 33, 39, 41.

Richmond, 168n.

Robson, 171, 174.

Rosz, 107, 109.

\section{S}

Sadras, 66, 106, 114, 162.

Saffin, 38-46, 49, 51, 83, 88-90, 98, 172-3.

St. Thomé, 4-5, 8, 19.

Saivid Sahib, 117-9, 123, 178.

"Sandy land", 39, 90, 95, 98, 121, 168n.

Sardar Khan, 93-7, 105, 111, 120-1, 126.

Savanur, 24-5.

Schreuder, 27, 53-5, 57.

Schwartz, 104.

Scott, 109.

Seijffer, 136-40.

Senff, 67-73, 82, 84-6, 111, 142.

Seringapatam, $43,60,62,76,78,82-3$, 88-9, 97-8, 104-5, 131, 136-9, 163, 178n.

Seventeen, The, 21, 56-7, 92, 124, 142n.$4 n ., 150,154,166,188$.

Shahgota, 116.

Shaik Raja, 172.

Siam, 3.

Simons, 107, 113, 115, 122-3, 126.

Sinha, VII, 175-6, 178.

Sivaji, 16-7.

Smith, 127.

Sode, 24-5.

Souillac, $144 \mathrm{n}$.

Spaniards, 6.

Spice Islands, 2-3, 6, 12, 54.

Srinivasa Rao, 74, 76-7, 79-80, 82-3, 88. $93,177-8$.

Srinizasachari, $152 \mathrm{n}$.

Stavorinus, 99-100.

Sulivan, 127-8n.

Sumatra, 11.

Surat, $4,6,11,13,18,53,67 \mathrm{n} ., 72 \mathrm{n}$., 124, 165.

Surion, 33, 39-40, 42-4, 46, 48, 64, 79-82, $88-9,136,144,173$.

\section{$\mathrm{T}$}

Tadama, 106.

Tambracheri, 146, 177.

Tanjore, 5, 9, 17, 19-20, 35, 66, 91n., $104,112,116,118-9,123,127,181-2$.

Tanur, 39. 44.

Tegnapatam, 6.

Tellicherry, $18,28,30,35,46,61,65,68$, 72n., 120, 126-7, 134, 145, 148, 178n.

Tinnevelly, 107.

Tipu Sultan, 52, 129-49, 151-61, 163, 167-8.

Topander, 105, 107, 162.

Tranquebar, 106, 122-4, 126, 130-2.

Travancore, 13-4, 22, 26, 31-2, 34, 38-40, $43-8$ n., 50, 52, 57-65, 67-71, 73-4, 76-7, $79,83,90,92,95-101,103,112,119$, $121,127-9,134-5,140,142-3,145-52$, 154-61, 164, 167, 170-1, 173.

Trichinopoly, 20-1, 66, 112, 160, 181.

Trichur, 48, 75.

Trincomalee, 124-5, 131.

Tuticorin, 8-9, 21, 34n., 108, 119.

\section{$\mathrm{V}$}

Vaikam, 45, 173.

van Albedyll, 140.

van Angelbeek, 108-9, 111, 119-22, 127-

30, 133-8, 140-53, 155-63.

van Braam, 125.

van Dam, 57n.

van Eck, 27-8, 34n., 38, 53n.

van Vechten, 23-4.

van Vlissingen, 89-90, 93-4, 104-7, 112-9,

$121,124 \mathrm{n} ., 126,144,180$.

van de Graaff, 141, 145, 160.

van der Parra, 53-4, 69.

Vellore, 5.

Vengurla, 10.

Vernede, 136-40.

Vijayanagar, 5, 16-7, 20.

Vizagapatam, 111n.

von Krause, 158-9.

W

Weyerman, 22-6, 57, 59.

Wheler, 108, 169.

Wilks, 89n., 153n., 158n., 171, 174-5, 177

8.

Wynad, 177-8.

\section{Z}

Zimmerman, 38-45, 49, 51, 98, 172. 
Jan van Lohuizen - 978-90-04-28655-9 Downloaded from Brill.come4/26/2023 09:57:33AM via free access 

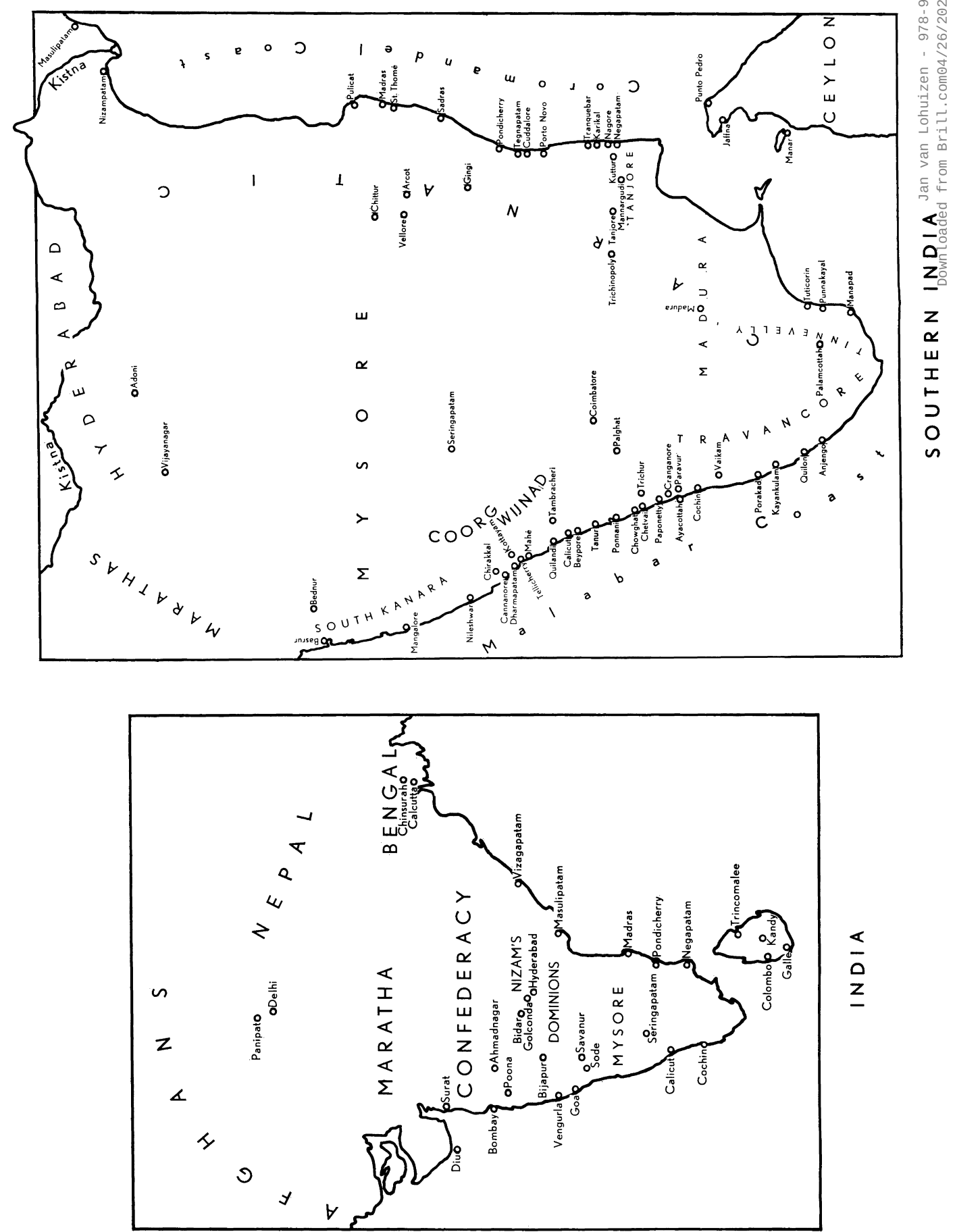